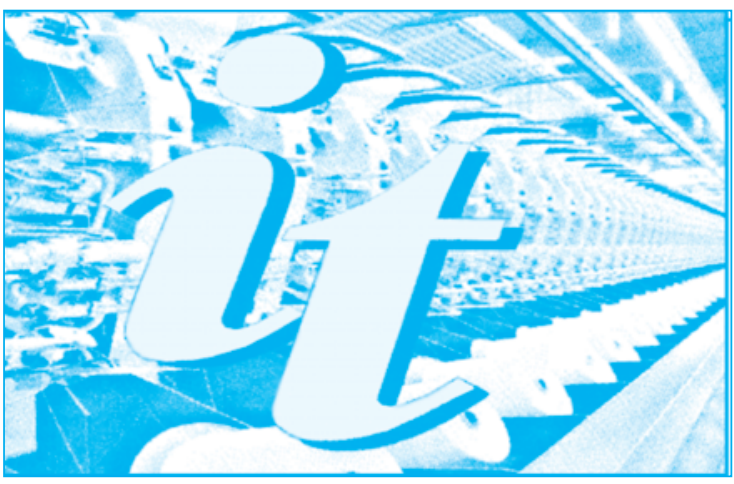

ISI rated journal, included in the ISI Master Journal List of the Institute of Science Information, Philadelphia, USA, starting with vol. 58, no. 1/2007, with impact factor 0.504 and AIS 0.046 in 2018.

The journal is indexed by CrossRef, starting with no. 1/2018 having the title DOI: https://doi.org/10.35530/IT.

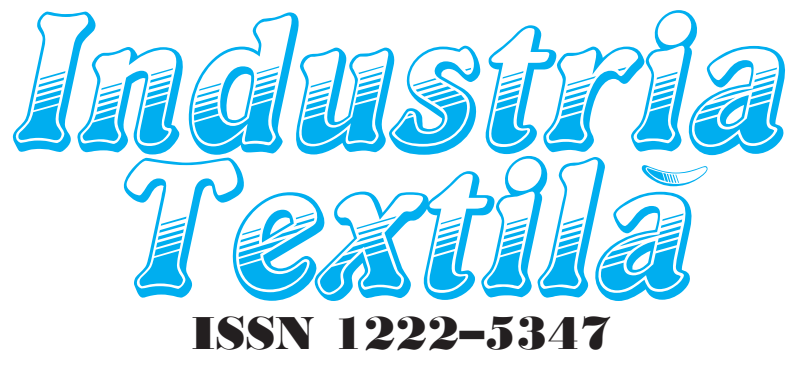

순, 12010

Edited in 6 issues per year, indexed and abstracted in

Science Citation Index Expanded (SciSearch ${ }^{\circledR}$ ), Materials Science Citation Index ${ }^{\circledR}$, Journal Citation Reports/Science Edition, World Textile

Abstracts, Chemical Abstracts, VINITI, Scopus, Toga FIZ technik ProQuest Central, Crossref

Edited with the Romanian Ministery of Research and Innovation suppor

\section{INIDUSTIRIA TEXTILĂ}

\section{EDITORIAL BOARD:}

Dr. Eng. CARMEN GHITULEASA GENERAL MANAGER

National R\&D Institute for Textiles and Leather, Bucharest, Romania

Dr. Eng. SABINA OLARU CS II, EDITOR IN CHIEF

National R\&D Institute for Textiles and Leather, Bucharest, Romania

Dr. Eng. EMILIA VISILEANU CS I, HONORIFIC EDITOR

National R\&D Institute for Textiles and Leather Bucharest, Romania

Associate Prof. Dr. Eng. MARIANA URSACHE DEAN

Faculty of Industrial Design and Business Management, Technical University

"Gh. Asachi", Iaşi, Romania

Prof. Dr. GELU ONOSE CSI

"Carol Davila" University of Medicine and Pharmacy, Bucharest, Romania

Prof. Dr. Eng. ERHAN ÖNER Marmara University, Turkey

Prof. Dr. S. MUGE YUKSELOGLU

Marmara University, Turkey

Prof Dr. DOINA I. POPESCU

The Bucharest University of Economic Studies, Bucharest, Romania

Prof. Dr. Eng. CARMEN LOGHIN PRO-RECTOR

Faculty of Industrial Design and Business Management, Technical University "Gh. Asachi”, laşi, Romania

Prof. Dr. MARGARETA STELEA FLORESCU The Bucharest University of Economic Studies, Bucharest, Romania

Prof. Dr. Eng. LUIS ALMEIDA

University of Minho, Portugal

Prof. Dr. LUCIAN CONSTANTIN HANGANU Technical University "Gh. Asachi”, laşi, Romania Dr. AMINODDIN HAJI

$P h D, M S c, B S c$, Textile Chemistry and Fiber Science ASSISTANT PROFESSOR

Textile Engineering Department

Yazd University, Yazd, Iran

$$
\text { Dr. MAZARI ADNAN }
$$

ASSISTANT PROFESSOR

Department of Textile Clothing, Faculty of Textile Engineering, Technical University of Liberec Czech Republic
GEORGETA POPESCU, SABINA OLARU, CLAUDIA NICULESCU,

TRAIAN FOIAȘI, ADRIAN SĂLISTTEAN

New 3D to 2D design method of clothing for teenagers

299-302

SAMAD ARAIN RABIA, HUSSAIN PEERZADA MAZHAR,

BASHEER ARAIN SAMAD, AYOUB ARBAB ALVIRA

An efficient ultrasonic and microwave assisted extraction of organic Henna dye

for dyeing of synthetic polyester fabric for superior color strength properties

303-308

ARZU YAVASCAOĞLU, RECEP EREN, GÜLCAN SÜLE

Analysis of thermo-physiological comfort properties of $100 \%$ acrylic,

acrylic/cotton, acrylic/viscose and acrylic/PES blended woven fabrics

AZMAT HUSSAIN, TAYYAB NAVEED, DANISH IQBAL, ZHICAI YU,

WANG XIN, IQBAL WAQAR, YUEQI ZHONG

Optimization of fabric drape measurement based on 3D model

$309-317$

MAZARI FUNDA BUYUK, MAZARI ADNAN, HAVELKA ANTONIN,

ADAMEK KAREL

Theoretical model: analysing theoretically the air flow through car seat

foam material

CONSTANTIN STOCHIOIU, BENOIT PIEZEL, AMEUR CHETTAH,

STEPHANE FONTAINE, HORIA GHEORGHIU

Basic modeling of the visco elastic behavior of flax fiber composites

$331-335$

DRAGOLJUB B. ĐORĐEVIĆ, MILOVAN VUKOVIĆ, SNEŽANA UROŠEVIĆ,

NADA ŠTRBAC, ALEKSANDRA VUKOVIĆ

Studying the corporate social responsibility in apparel and textile industry

HA LUU, FERNANDO FERREIRA, ANTÓNIO DINIS MARQUES

Digitisation and industry 4.0 in the Portuguese T\&C sector

BOGDAN ALEXANDRU VIȚĂLARU, ALEXANDRA GABRIELA ENE,

LAURENTIU ALEXANDRU CHIOTOROIU

The importance of the Dacron cuffs in peritoneal dialysis catheters for acute

kidney injury applied in veterinary medicine

$346-349$

ESIN SARIOĞLU

Quality optimization of ring spun yarns produced from blends of regenerated cellulosic fibres with cotton and polyester

RODICA HARPA, CRISTINA PIROI, IRINA CRISTIAN,

EMILIA VISILEANU, MIRELA BLAGA

Sensory analysis of textiles: case study of an assortment of stretch

denim fabrics

$318-323$

HAJI GHULAM QUTAB, MUHAMMAD MOHSIN, NAVEED RAMZAN,

SYED WAQAS AHMAD, ELENA CORNELIA MITRAN

Performance enhancement of diammonium hydrogen phosphate as halogen and formaldehyde free sustainable fire retardant

SUNDARARAMAN BANUMATHY, RAMALINGAM NEELAKANDAN

Study on factors influencing customer leaving an apparel store without

a purchase

374-378

GIZEM KARAKAN GÜNAYDIN

Effect of coating ratio and weft density on some physical properties

of upholstery fabrics

379-385

RUI HUA YANG, YAYA XU, CHUN PING XIE, BO JUN XU,

HONG BO WANG, WEI DONG GAO

Color matching model of woven fabric produced by multi-color blended

rotor spun wool yarn

Web of Science Journal Category: Materials Science, Textiles

Aknowledged in Romania, in the engineering sciences domain,

by the National Council of the Scientific Research from the Higher Education

(CNCSIS), in group $A$ 


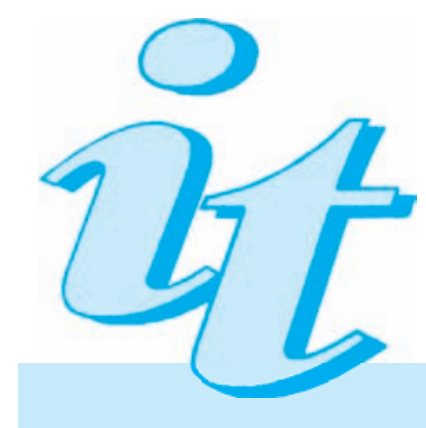

Scientific reviewers for the papers published in this number:

Dr. ZEESHAN KHATRI, Nano Fusion Technology Research Group, Faculty of Textile Science and Technology, Shinshu University, Japan

Dr. FANG XU DONG, Georgia Institute of Technology, United States

Dr. NAVEED RIZVI, Research \& Development Manager, RONCO, Canada

Prof. LUBOS HES, Technical University of Liberec, Czech Republic

Dr. IFTIKHAR ALI, Department of Textile Engineering, Mehran University of Engineering and Technology, Jamshoro, Sindh, Pakistan

Asst. Prof. Dr. FAROOQ ASSAD, Department of Fiber and Textile Technology, Faculty of Engineering and Technology, University of Agriculture, Faisalabad, Pakistan

Prof. Dr. Eng. ANTON HADAR, University Politehnica of Bucharest, Romania

Prof. Dr. Eng. GABRIEL JIGA, University Politehnica of Bucharest, Romania

Assoc. Prof. LILIANA INDRIE, The University of Oradea, Faculty of Energy Engineering, Department of Textiles, Leather and Industrial Management, Romania

Prof. BRUNO ZAVRŠNIK, University of Maribor, Faculty of Economics and Business, Slovenia

Ph.D. GIORGIOS PRINIOTAKIS, Piraeus University of Applied Science, School of Applied Technology, Department of Textile Engineering, Greece

Dr. Sc. ANDREJA RUDOLF, University of Maribor, Faculty of Mechanical Engineering, Slovenia

Conf. Univ. Dr. FLORIN MUSELIN, USAMVB Timişoara, Faculty of Veterinary Medicine, Romania

Asst. Prof. Dr. GIZEM KARAKAN GÜNAYDIN, Pamukkale University, Turkey

Assoc. Prof. Dr. HATICE KÜBRA KAYNAK, Gaziantep University, Turkey

Asst. Prof. Dr. Sc. DAIVA MIKUČIONIENĖ, Kaunas University of Technology, Department of Materials Engineering, Lithuania

Prof. Dr. Sc. ZORAN STJEPANOVIČ, University of Maribor, Faculty of Mechanical Engineering, Department of Textiles Materials and Design, Slovenia

Prof. Dr. ELSAYED ELNASHAR, Kafrelsheikh University, Egypt

Prof. Dr. DILEK KUT, Uludağ University, Faculty of Textile Engineering, Turkey

Prof. Dr. SEMA PALAMUTCU, Pamukkale University, Faculty of Textile Engineering, Turkey

Assoc. Prof. Dr. ERHAN KENAN ÇEVEN, Uludağ University, Faculty of Textile Engineering, Turkey

Assoc. Prof. Dr. HAMEED KHAN, MEASI Institute of Management, India

\section{EDITORIAL STAFF}

General Manager: Dr. Eng. Carmen Ghițuleasa

Editor-in-chief: Dr. Eng. Sabina Olaru

Onorific editor: Dr. Eng. Emilia Visileanu

Graphic designer: Florin Prisecaru

Translator: Cătălina Costea

Site administrator: Constantin Dragomir

e-mail: industriatextila@incdtp.ro

The INDUSTRIA TEXTILA magazine, edited by INCDTP BUCHAREST, implements and respects Regulation 2016/679/EU on the protection of individuals with regard to the processing of personal data and on the free movement of such data ("RGPD"). For information, please visit the Personal Data Processing Protection Policy link: E-mail DPO rpd@certex.ro

Journal edited in colaboration with Editura AGIR, 118 Calea Victoriei, sector 1, Bucharest, tel./fax: 021-316.89.92; 021-316.89.93; e-mail: editura@agir.ro, www.edituraagir.ro 


\title{
New 3D to 2D design method of clothing for teenagers
}

\author{
DOI: $10.35530 / 1 T .070 .04 .1585$
}

\section{REZUMAT - ABSTRACT}

\section{O nouă metodă de realizare a tiparelor 2D din produsul 3D pentru articolele de îmbrăcăminte ale adolescenților}

Adolescența reprezintă o perioadă de tranziție și presupune atât modificări la nivel fizic, cât și modificări la nivel de comportament și personalitate. Produsele pentru adolescenți se caracterizează printr-o mare varietate de forme și stiluri. O mare parte din stilul de îmbrăcăminte al adolescenților este reprezentat de produse adaptate corpului, deci este foarte important să se stabilească o potrivire bună între ele. În prezent, un produs de îmbrăcăminte poate fi dezvoltat cu ajutorul instrumentelor performante existente, cum ar fi software-ul de proiectare a tiparelor, scanarea $3 D$ pentru achiziția datelor antropometrice și software-ul de simulare, modelare și ajustare 2D/3D. Totuși, acestea nu sunt suficiente pentru dezvoltarea de produse de înaltă performanță, decât atunci când sunt implicate cunoștințele și experiența unui specialist inginer/cercetător și a unui stilist.

Lucrarea prezintă noua metodă de proiectare a tiparelor $2 D$ din produsul $3 D$ a unor produse vestimentare pentru adolescenți având la bază datele 3D antropometrice actuale din standardul antropometric elaborat de către INCDTP. Metoda inovativă de realizare a tiparelor de bază 2D din produsul $3 D$ utilizează ca instrumente modulele $3 D$ Flattening, $3 D$ Simulations ale programului Optitex PDS și oferă proiectantului avantajul vizualizării preliminare a formei produsului și a corespondenței acestora cu dimensiunile corpului. Simularea 3D și modelarea virtuală a produselor vestimentare pentru adolescenți este o metodologie pentru verificarea corespondenței corp-produs și rectificarea eventualelor neconcordanț. Simularea și modelarea $3 D$ se face direct pe manechinul parametrizat cu valorile antropometrice din standard și cu proprietățile și aspectul materialului utilizat.

Cuvinte-cheie: îmbrăcăminte pentru adolescenți, proiectarea tiparelor, simulare 3D, standard antropometric

\section{New 3D to 2D design method of clothing for teenagers}

Adolescence is a transition period and involves physical changes and also changes in behavior and personality. Products for teenagers are characterized by a wide variety of shapes and styles. A large proportion in the teenagers clothing style is represented by body-adjusted products, so it's very important to establish a good match between them. Nowadays, a clothing product can be developed with existing performance tools such as pattern design software, 3D scanning for anthropometric data acquisition and 2D/3D simulation, modelling and fitting software. However, these are not enough for the development of high-performance products, unless the knowledge and experience of a engineer/ researcher specialist and stylist is involved.

The paper presents the new $3 D$ to $2 D$ design method of clothing for teenagers, based on current anthropometric 3D data from the anthropometric standard developed by INCDTP. The innovative design method for obtaining the $2 D$ basic patterns from the $3 D$ product uses as tools the $3 D$ Flattening module of the Optitex PDS, and offers the pattern designer the advantage of previewing the shape of the product and its correspondence with body size. The module is newly developed by the Optitex PDS software, existing in INCDTP endowment.

Another innovation is to replace the classic grading of patterns, for different sizes and configurations, with the modeling of the mannequin by replacing standardized anthropometric dimensions. The markings remain in the position corresponding to the anthropometric points, moving proportionally with the replaced anthropometric dimensions.

Keywords: teenagers' clothing, patterns design, 3D simulation, anthropometric standard

\section{INTRODUCTION}

Adolescence is the period of biological, psychological and social transition from puberty to maturity. The age range at which this transition occurs is slightly different from one individual to another and depends on several factors: sex (girls generally become teenagers before boys), socio-cultural background etc. The World Health Organization defines adolescence as being the period between 10 and 19 years, but in many Western countries it is considered that adolescence begins between 11 and 13 years for girls, 12-14 years for boys, and ends around the age of 19-21 years for both sexes. This transition period involves physical changes and also changes in behavior and personality.

At this age, compared to childhood, clothing becomes an instrument of communication with others, a way of expressing the personality and, last but not least, an attempt to define the style. It is also a way to highlight the silhouette that is undergoing major transformations during this period. 
Products for teenagers are characterized by a wide variety of shapes and styles. The teenager is always fashionable, easily influenced by the whims of fashion, but equally easy to give up after a period of time, which is why the clothing manufacturers and retailers have great interest for this category of clients. At 14-15 years old, young people experience different styles and after this period to shape their personality and to go to the adult stage.

The development of clothing products for this age category is made by characterizing the anthropomorphological changes that have a significant evolution [1].

A large proportion in the teenagers clothing style is represented by body-adjusted products, so it's very important to establish a good match between them. Nowadays, a clothing product can be developed with existing performance tools such as performance design software, 3D scanning for anthropometric data acquisition and 2D/3D simulation, modeling and fitting software. However, these are not enough for the development of high-performance products, unless the knowledge and experience of an engineer/researcher specialist and stylist is involved.

\section{ANALYSIS OF ANTHROPOMETRIC DATA OBTAINED BY 3D SCANNING}

Teenagers clothing product development is based on anthropometric data found in SR 13546/2012 developed by the National Research and Development Institute for Textiles and Leather [2-4]. This includes dimensional characteristics taken by 3D body scanning of Romanian teenagers, by age groups. Of 150 measurements resulted from 3D body scanning, 44 dimensional characteristics that provide information needed for clothing designers and pattern makers for sizing patterns and clothing were selected.

The main size for size designation of teenagers clothing is body height. This choice corresponds with European standards for teenagers clothing size designation, thus achieving harmonization.

The standardized heights of Romanian teenagers aged 14-19 years are:

- girls: 152; 158; 164; $170 \mathrm{~cm}$;

- boys: 158; 164; 170; 176; $182 \mathrm{~cm}$.

Interdimensional range value for the main dimension, body height is $6 \mathrm{~cm}$. The secondary standardized dimensions of the body corresponding to each height as main size were calculated statistically.

\section{INNOVATIVE DESIGN METHOD FOR OBTAINING THE 2D PATTERNS FROM THE 3D PRODUCT}

An innovative method for obtaining basic patterns for adolescent clothing is the method of developing 2D patterns from the 3D product. The method consists in processing the flattened surfaces of a $3 \mathrm{D}$ product and is using the 3D Flattener-Form-fitting design module. The module is newly developed by the Optitex PDS software, existing in INCDTP endowment.
Using the specific features, the pattern designer's knowledge and its creativity, the surface of the 3D object can be transformed, respectively the human body on which the contour of the desired product is drawn in $2 \mathrm{D}$ pieces, resulting in an exact correspondence between the size of the pattern and the body dimensions. Another advantage of the new method consists in the direct visualization on the body of the joint lines between the pieces of a product, the shape of the product and the desired length. The 2D surfaces thus obtained are the pattern for a body-adjusted product, of which the basic looseness addition is 0 . The new innovative method of developing 2D patterns from the 3D product is a process of transforming the flattened surfaces of the body into the patterns of a product, which is actually positioned to the body at a certain distance, depending on its type and purpose and on the characteristics of the used material.

Another innovation is to replace the classic grading of patterns, for different sizes and configurations, with the modeling of the mannequin by replacing standardized anthropometric dimensions. The markings remain in the position corresponding to the anthropometric points, moving proportionally with the replaced anthropometric dimensions [5].

The method of obtaining the 2D patterns from the 3D product consists of the following steps:

- Step 1. Parameterization of the virtual mannequin with the standardized size values for the desired size or real body for the individualized product. Thus, the anthropometric dimensions of length and circumference required for the pattern construction are selected depending on the type of product. In the "Model properties" table of the specialized simulation program, 3D OPTITEX PDS, the values are entered corresponding to the anthropometric dimensions of the anthropometric standard SR 13546: 2012 - Clothing. Body dimensions for children between 6 and 19 years old, developed by INCDTP (figure 1).

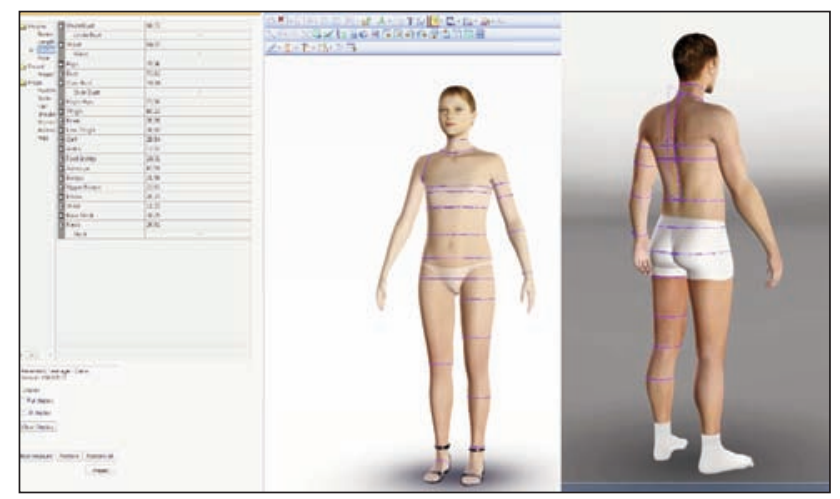

Fig. 1. Parameterization of the virtual mannequin

- Step 2. Place the points that define the contour of the desired product on the mannequin using the "Draw Path" function. Depending on the type of the product and its relative location to the support surface, the points corresponding to the main anthropometric points are placed following the markings on 
the virtual mannequin and characteristic points of its shape and length.

- Step 3. Draw the outline through points in order to obtain a closed contour. The points are joined through contour lines so as to produce 3D surfaces corresponding to the component pieces of the product. These lines change by following the curvature of the body using the "Edit pins" function (figure 2).

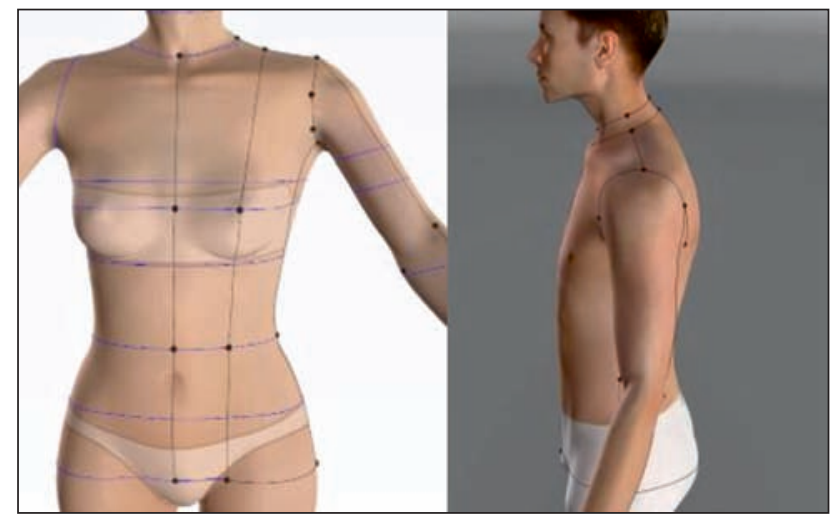

Fig. 2. Drawing the 3D contour of the product through characteristic anthropometric points

- Step 4. Flatten 3D surfaces so obtained in 2D surfaces using the "Build Patch" function. This results in the deployable surfaces that are visualized in the Optitex PDS program and where they can be modified using its functions. These surfaces correspond to the shape and dimensions of the body, with markings for the main anthropometric points (figure 3 ).

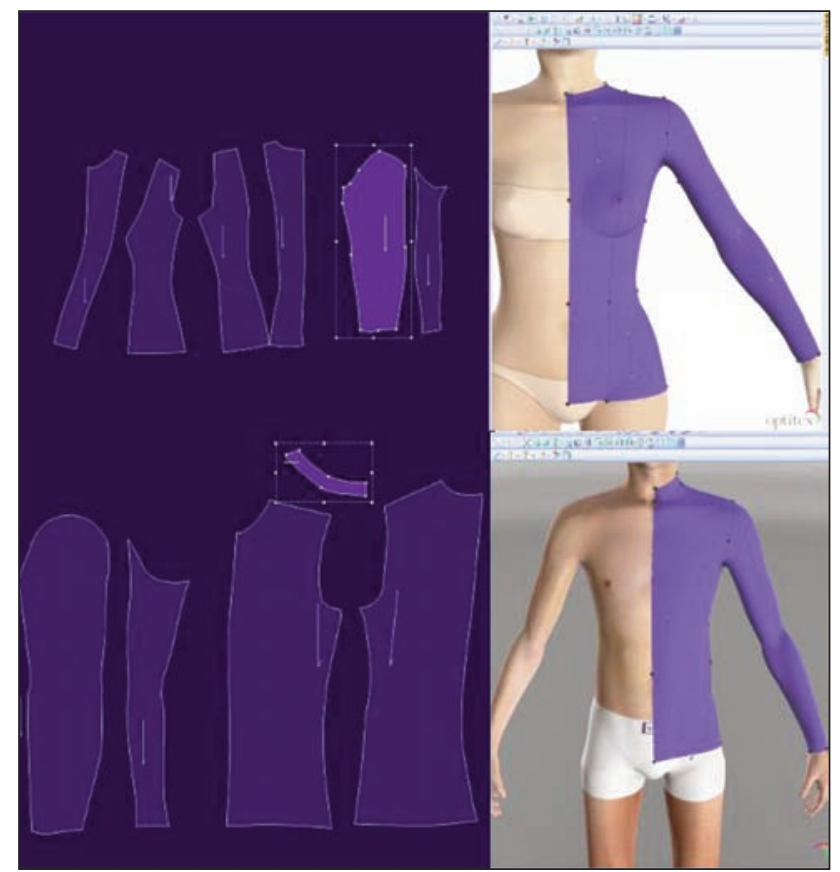

Fig. 3. Flatten the surfaces of the 3D product

- Step 5. Processing of the 2D surface contour, add product specific additions and obtaining the basic patterns. Depending on the type and silhouette of the product, the specific additions are determined and also the values with which the main segments of the pattern are resized [6-7]. In this process, the position of the main anthropometric points is modified and the contour that passes through these points is processed (figure 4).

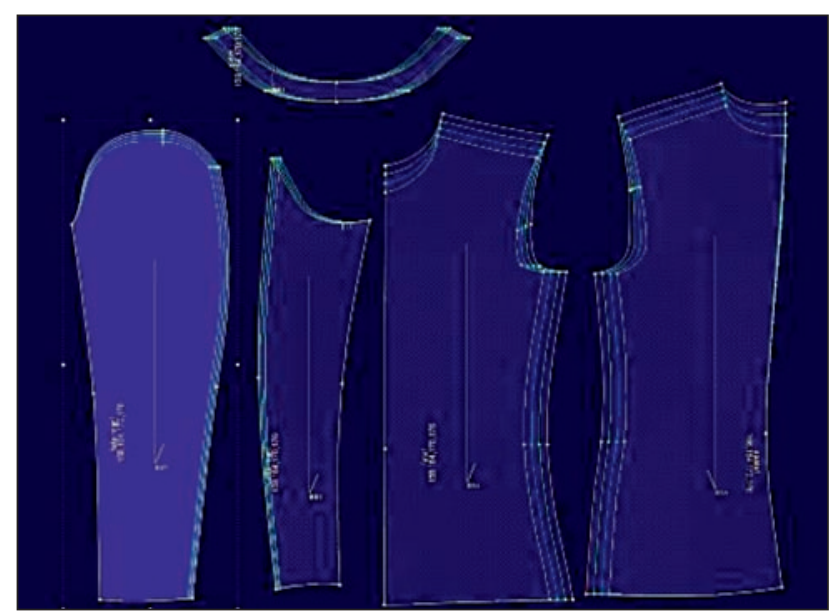

Fig. 4. Basic design of the jacket for teenagers

\section{CONCLUSIONS}

The newly innovative method, developed and implemented in the research, consists in the realization of the 2D patterns starting from the 3D product, addressed to teenagers of different age groups. The new pattern design method takes into account agespecific requirements, material characteristics, destination of products, and specifically and compulsorily, the new 3D anthropometric dimensions resulting from the anthropometric survey carried out by INCDTP.

Application of research results will allow the producers and designers of clothing items for teenagers to design products perfectly adapted to their standard sizes as follows:

1. The use of parameters for general characterization of the shape and constructive characteristics of the clothing products for teenagers depending on age category and the destination and the type of product; 2. The use of the necessary 3D anthropometric dimensions and the additions to the development of the design algorithms. The main anthropometric dimension for the determination of the clothing size for teenagers is the body height, the other necessary dimensions being selected from the standard depending on it;

3 . The use of the new design method of the 2D patterns starting from the 3D product, which will lead to the development of very precise patterns in a reduced time.

\section{ACKNOWLEDGEMENTS}

This paper was elaborated as part of the Nucleu program, elaborated with the support of ANCSI, project no. PN 16340501. The publication of the paper is funded by the Romanian Ministry of Research and Innovation within Program 1 - Development of the national RD system, Subprogram 1.2 - Institutional Performance - RDI excellence funding projects, Contract no. 6PFE/2018. 


\section{BIBLIOGRAPHY}

[1] Babcinetchi, V., Cercetări în domeniul caracterizării corpului omenesc din punct de vedere antropomorfologic cu aplicații în arta și proiectarea constructivă a vestimentației, Editura Politehnium, lasi, 2011, ISBN 978-973-621-383-3

[2] Standard SR 13546/2012. Confecţii. Dimensiunile corpului pentru copii cu varsta cuprinsă între 6 şi 19 ani

[3] Hong, Y., Bruniaux, P., Zhang, J., Liu, K., Dong, M., Chen, Y., Application of 3D-to-2D garment design for atypical morphology: a design case for physically disabled people with scoliosis, In: Industria Textila, 2018, 69, 1, pp. 59-64

[4] Rudolf, A., Stjepanovič, Z., Cupar, A., Designing the functional garments for people with physical disabilitiesor kyphosis by using computer simulation techniques, In: Industria Textila, 2019, 70, 2, pp. 182-191

[5] Pintilie, E., Ciubotaru, G., Avădanei, M., Proiectarea confecţiilor textile asistate de calculator, 2006, Editura Performantica, laşi , ISBN 973-730-259-1

[6] Donnanno, A., La tecnica dei modelli, Gonne e camicie, Pantaloni e tute, Editura Ikon editrice, Milano, 2002

[7] Dong, M., Hong, Y., Zhang, J., Liu, K., Wagner, M., Jiang, A body measurements and sensory evaluation-based classification of lower body shapes for developing customized pants design, In: Industria Textila, 2018, 69, 2, pp. 111-117

\section{Authors:}

GEORGETA POPESCU, SABINA OLARU, CLAUDIA NICULESCU, TRAIAN FOIAȘI, ADRIAN SĂLIȘTEAN

National R\&D Institute for Textiles and Leather Bucharest (INCDTP)

Lucretiu Patrascanu Street, 16, 030508 Bucharest, Romania

e-mail: office@incdtp.ro, webpage: http://www.incdtp.ro

Corresponding author:

GEORGETA POPESCU

e-mail: georgeta.popescu@certex.ro 


\title{
An efficient ultrasonic and microwave assisted extraction of organic Henna dye for dyeing of synthetic polyester fabric for superior color strength properties
}

\author{
DOI: $10.35530 / I T .070 .04 .1551$
}

Extracție eficientă cu ultrasunete și microunde a colorantului organic Henna pentru vopsirea materialelor textile sintetice din poliester cu proprietăți superioare de rezistență a culorii

Tehnică de extracție eficientă din punct de vedere energetic și ecologică pentru extracția colorantului organic Henna a fost propusă pentru vopsirea materialelor textile sintetice din poliester, cu proprietăți de rezistență ridicată a culorii, pentru a satisface cererea mondială de procese și produse eficiente din punct de vedere energetic și ecologice, în comparație cu metodele convenționale de extracție cu solvent. Metodele de extracție cu ultrasunete și microunde au fost ulterior analizate și optimizate, în ceea ce privește timpul de extracție și raportul de flotă. Pentru aobserva efectul pH-ului asupra vopsirii naturale a poliesterului cu colorant Henna, vopsirea a fost efectuată la două valoridiferite ale pH-ului. Tehnicile cu ultrasunete și cu microunde au extras semnificativ colorantul Henna, într-un timp mai scurt decât metoda convențională de extracție cu solvent. Rezistențe mai mari ale culorii au fost înregistrate prin extracția cu ultrasunete și microunde a colorantului Henna la vopsirea materialelor textile din poliester.

Cuvinte-cheie: colorant natural Henna, extracție cu microunde, vopsire organică, material textil din poliester, extracție cu ultrasunete

An efficient ultrasonic and microwave assisted extraction of organic Henna dye for dyeing of synthetic polyester fabric for superior color strength properties

An energy efficient and 'green' extraction technique for extraction of organic Henna dye has been proposed for the dyeing of synthetic polyester fabric with high fastness and color strength propertiesto fulfill the world's highest demand towards energy efficient and 'green' processes and products and compared with conventional solvent extraction methods. The ultrasonic and microwave extraction methods were further analyzed and optimized in terms of extraction time and liquor ratio. To observe the effect of $\mathrm{pH}$ on the natural dyeing of polyester with Henna dye, dyeing were carried out at two different $\mathrm{pH}$. Ultrasonic and microwave techniques noticeably extracted Henna dye with in less time than conventional solvent extraction method. High color strength and fastness properties were observed with ultrasonic and microwave extracted Henna dyeing of polyester fabrics.

Keywords: Henna natural dyes, microwave assisted extraction,organic dyeing, polyester fabrics, ultrasonic assisted extraction

\section{INTRODUCTION}

Manufacturing and use of synthetic dyes are a serious distress of creating water contamination and environmental pollution. During manufacturing, synthetic dyes produces various noxious residues in air and water which creates a serious health concerns to workers [1]. Correspondingly during usage, various toxic behaviors of synthetic dyes have been reported specifically carcinogenic and mutagenic [2-3] which leads to the exclusion of various synthetic dyes specially disperse dyes listed in ZDHC (zero discharge of hazardous chemicals programme) [4]. As a result, there is a great resurgence of interest in natural organic dyes to replace toxic synthetic dyes for dyeing of textile materials [5]. Natural sources for colors are nontoxic, ecological and biodegradable [6-7], therefore colorants from natural sources have been established as 'green' alternatives of synthetic dyes [8-10].

Extraction of natural color from their origin is the most important stage in natural dye applications as the efficiency of extraction method strongly influences the color depth and hence the dyeing behavior of the textile material to which it is used. Extraction of organic dyes involves the route to separate colorants from plant sources, which are strongly bound to plant cell membrane. Traditionally, a number of solvents have been used for the separation of color chromophore from the plant material such as acids, alkalis, alcoholsand enzymes with or without Soxchlet apparatus [11-13]. These methods are time consuming [14] and required huge quantity of solvents which due to toxic nature causes environmental problems and eliminate rewards of using natural colors. Moreover, need for solventsremoval entirely from dye solution after extraction due to serious negative effects on dyeing 
and color fastness properties of fabrics, made the extraction and dyeing with natural colors expensive and inefficient [15]. Therefore, to acquire comprehensive benefit of natural resources of dyes as green alternatives of synthetic colorants, it is mandatory to develop and standardize an extraction system which is nontoxic (no use of chemicals), inexpensive, energy efficient, and more environment friendly.

In this concern, advanced technologies such as ultrasonic and microwave has been presented as an energy efficient and environment friendly [16-17] developments for natural color extraction and receive the significant consideration of researchers due to their potential advantages like faster and solvent free extraction [18] over conventional solvent extraction methods [19]. Recently, authors found that ultrasonic [20] as well as microwave extraction [21] as an advanced and efficient techniques for extraction.

Ultrasonic waves rupture the cell membrane by means of forcibility acting shockwaves created with the formation and collapsing of bubbles resulted in improved percolating of color constituent and hence extraction efficiency. On the other hand, microwave irradiation technique for extraction provide efficient colorant extraction by means of microwave heating which specifically heated the microscopic traces of moisture within the plant cell, which in turn generates remarkable pressure on the plant cell wall [19]. The inside pressure resulted in intensive rupturing of the cell wall, and consequently facilitates removal of the targeted color constituents to the water/solvent thus improving the yield.

Henna (Lawsoniainermis Linn) belongs to the family Lythraceae is extensively cultivated in Middle Eastern and Northern African countries. Henna leaves (Lawsoniainermis) has been used as a major source of natural color for human skin, hairs as well as textile fibers due to its antibacterial [22] and UV protection [23] properties. Chemically, Henna lawsone chromophore belongs to the naphthoquinone family with name 2-hydroxy-1,4-naphthoquinone shown in figure 1, a, commercially known as Natural Orange 6. Cheap cost and easy availability of Henna natural dyes made it very popular among natural fibers such as cotton [12], wool [22], and silk [24] due to their higher absorbency. Though, very limited studies are available on the use of Henna dye onmost important synthetic fibresin the world such as polyester [25].
Due to highest demand of polyester fabric [26] and banned on various toxic disperse dyes [4], herein we selected Henna dye as a 'green alternative' to disperse dye for polyester fibre.

In this work, we proposed a novel technique to extract organic colorant from Henna dye by means of energy efficient and inexpensive ultrasonic and microwave techniques. Ultrasonic and microwave assisted extraction of organic Henna dye was subsequently applied over synthetic polyester fabrics and its dyeing characteristics were analyzed. Ultrasonic and microwave assisted extraction of organic Henna dye was optimized to provide ideal conditions to use Henna dye on polyester fibre industrially without any difficulty. The ionic performance of any dye compound and therefore its characteristic color on specific fibre depends on the $\mathrm{pH}$ of the media and hence fibre-dye interactions. Therefore, to observe the chemistry of Henna dye towards polyester fibres at different dye bath $\mathrm{pH}$, two $\mathrm{pH}$ conditions were used to dye the polyester fibre with Henna dye at neutral (7) and acidic (4.5-5) $\mathrm{pH}$. As to our best knowledge, this is the first research report on the ultrasonic and microwave extraction of Henna natural dye for the dyeing of synthetic polyester material. This method of extraction is expected to be a very simple method and aim to provide ready to use dyes for coloration without the need for prolonged post treatments of solvent extraction method.

\section{EXPERIMENTAL}

\section{Materials and equipment}

For the experimental work, Bleached, $100 \%$ polyester fabric of 90 GSM was kindly supplied by Gul Ahmad textile mills, Karachi, Pakistan. Natural Henna leaves were obtained from Badin origin, Pakistan. All chemicals and mordants including ferrous sulfate $\left(\mathrm{FeSO}_{4} \cdot 7 \mathrm{H}_{2} \mathrm{O}\right.$ ), aluminum potassium sulfate (KAl $\left.\left(\mathrm{SO}_{4}\right)_{2}\right)$, sodium Hydroxide, sodium carbonate, acetic acid, andhydrochloric acid used were purchased from Merck. Lemon used as a bio mordant was purchased from the local market, Hyderabad, Pakistan. Dyeing of polyester fabric was carried out at High temperature high pressure dyeing machine (Rapid Labortex $\mathrm{H}-120$, Taiwan). For the extraction of Henna leaves, ultrasonic (US) bath $(40 \mathrm{KHz})$ and household microwave oven of $2.45 \mathrm{GHz}$ frequency was used. To

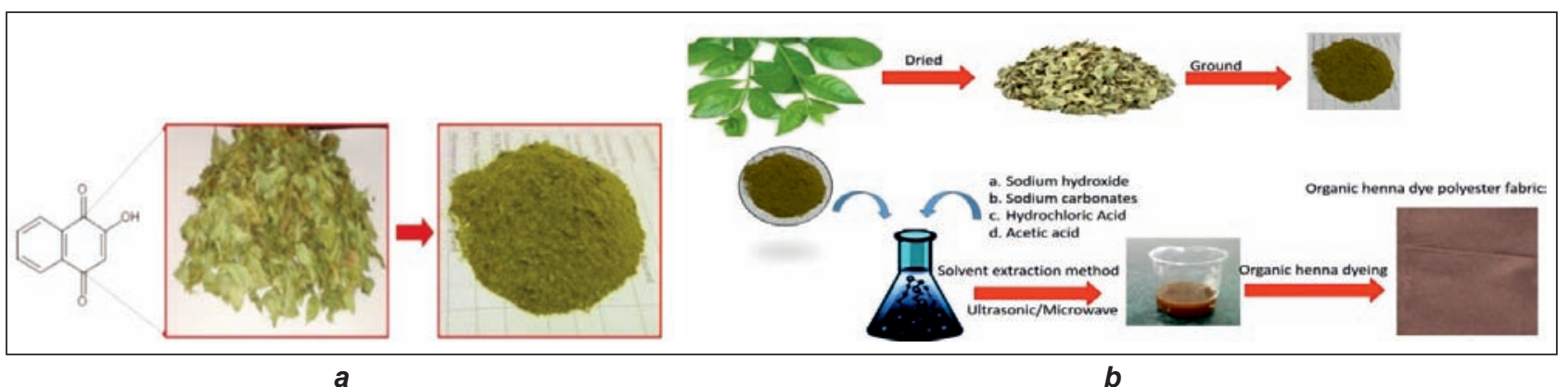

Fig. 1. $a$-chemical structure of Henna Lawsone chromophore; $b$ - layout of extraction of Henna dye 
increase the efficiency of US bath, agitation of ultrasonic bath was executed electrically in local means. The power input was $300 \mathrm{~W}$ and $700 \mathrm{~W}$ for ultrasonic and microwave respectively. Soxchlet evaporator was used to separate water from all the extracted color solutions separately to concentrate the dye solution.

\section{Extractionof natural Henna dye \\ Ultrasonic assisted extraction}

Henna leaves were thoroughly washed with distilled water and then dried under open air for 24 hours followed by oven drying at $50^{\circ} \mathrm{C}$ for two hours. Dried Henna leaves were grounded into powder form by using agate mortar. For the ultrasonic extraction of Henna natural dye, the color was extracted from Henna leaves powder by using an Ultrasonic bath for 30 minutes at $50^{\circ} \mathrm{C}$ [27]. $100 \mathrm{ml}$ of water was used for extraction with the liquor ratio (Henna dye in gram to water in $\mathrm{ml}$ ) 1:20. The extracted color was filtered with tea filter and then the constant amount of water (approximately $30 \mathrm{ml}$ ) was separated by using Soxchlet evaporator for 20 minutes.

\section{Microwave assisted extraction}

For the extraction of Henna dye with microwave, the same procedure was followed as in ultrasonic assisted extraction except that the Henna dye sample was treated in microwave oven of $2.45 \mathrm{MHz}$ and $700 \mathrm{~W}$ power for 4 minutes at boiling temperature.

\section{Solvent assisted extraction}

For comparison studies, solvent extraction of Henna dye was carried out with the exact material as in ultrasonic assisted extraction and treated with sodium hydroxide, sodium carbonate, acetic acid and hydrochloric acid separately for 24 hours at room temperature with the method reported in previous work [28]. The color was also extracted from Henna leaves powder for 24 hours with water without any solvent at room temperature and used as a control extraction method.

\section{Dyeing of Polyester Fabric with natural Henna dye}

The Henna dye color solution from solvent, ultrasonic and microwave assisted extraction was used to dye separately different samples of polyester at $130^{\circ} \mathrm{C}$ for 60 minutes on conventional high temperature and high pressure (HTHP) dyeing machine. To observe the effect of dye bath $\mathrm{pH}$ on the dyeing behavior of Henna dye, dyeing was carried out at two $\mathrm{pH}$ conditions such as acidic (4.5-5) and neutral (7). The extraction method which gave the optimum color strength (K/S) on polyester fabric was further optimized in terms of extraction time and liquor ratio (weight of crushed Henna leaves in gram to water in $\mathrm{mL})$.

\section{Optimization of Ultrasonic and Microwave} assisted extraction of organic Henna natural dye

For the optimization of extraction time, ultrasonic extractions of Henna dye were carried out for various time durations, viz., for 10, 30, 50, 70 and 90 minutes, respectively at $50^{\circ} \mathrm{C}$ temperature with Henna dye to liquor ratio 1:20. All the extracted solutions for different time were used to dye the polyester fabric with the method given above. The extraction which gave the optimum color strength was further utilized to optimize the Henna dye to liquor ratio. For the optimization of Henna dye to liquor ratio, different liquor ratios were used for ultrasonic extraction i-e; 1:20, 1:40, 1:60, 1:80 and 1:100. The extract which gave the optimum color strength (K/S) was further analyzed in terms of fastness properties. The same procedure was followed for the optimization of extraction time and liquor ratio with microwave extraction, with the exception that, the microwave extractions were carried out for 1, 2, 3, 4 and 5 minutes at boiling temperature for time optimization. For the optimization of liquor ratio, the same procedure was followed as discussed for ultrasonic extraction. The schematic illustration of extraction of Henna dyes with ultrasonic, microwave and solvents and fabric dyeing is shown in figure $1, b$.

\section{CHARACTERIZATION}

For the spectrophotometric studies of the polyester dyed fabric, Reflectance values of each dyed sample were measured on a Data color SF600 spectrophotometer with illuminant D65 and UV and specular component included. Each sample was measured at five different locations and the average value was calculated. Using the reflectance value at maximum absorption, the color yield (K/S) was calculated with the Kubelka-Munk equation Eq. 1

$$
\left(\frac{K}{S}\right)_{\lambda \max }=\frac{(1-R)^{2}}{2 R}
$$

$K$ is the absorbance, $S$ - the scattering coefficient and $R$ - the reflection.

\section{RESULTS AND DISCUSSION}

\section{Color strength measurement}

\section{Effect of extraction method}

The results of polyester fabric samples dyed with ultrasonic, microwave and solvent assisted extraction of organic Henna dye presented in figure $2, a$ and $b$ respectively with water as a control extraction process. Higher color strength of polyester fabric dyed with Henna color extracted by ultrasonic (5.5) and microwave (6) was achieved as compared to the control (water) extracted Henna dye (5.2) at acidic pH 4.5-5. On the other hand, solvent extraction method, either acidic or alkaline extraction displayed less color strength as compared to control (water) extracted Henna dye. This might be due to the high reactivity of lawsone in alkaline extraction [12] and hydrolyzation of the Henna lawsone molecule in highly acidic environment. On the other hand, with ultrasonic and microwave extraction of Henna dye, it was possible to achieve same or even more color strength in less time (30 minutes and 4 minutes, respectively) as compared to 24 hours aqueous/solvent extraction. 


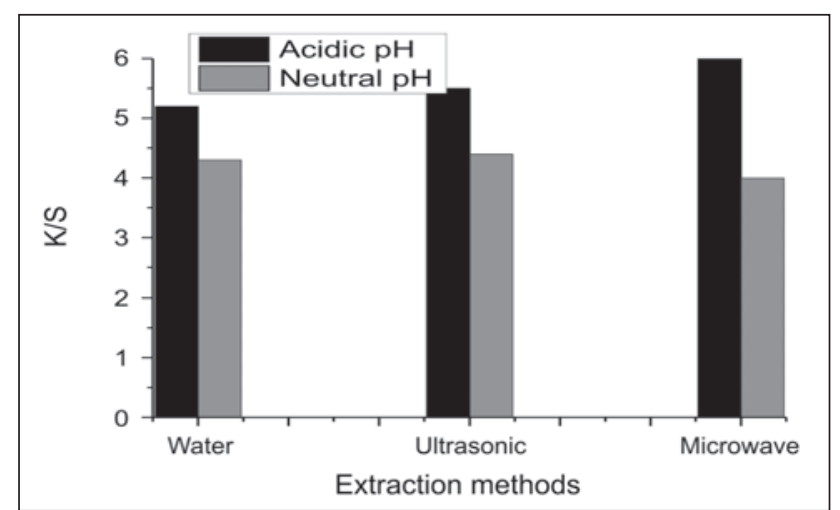

a

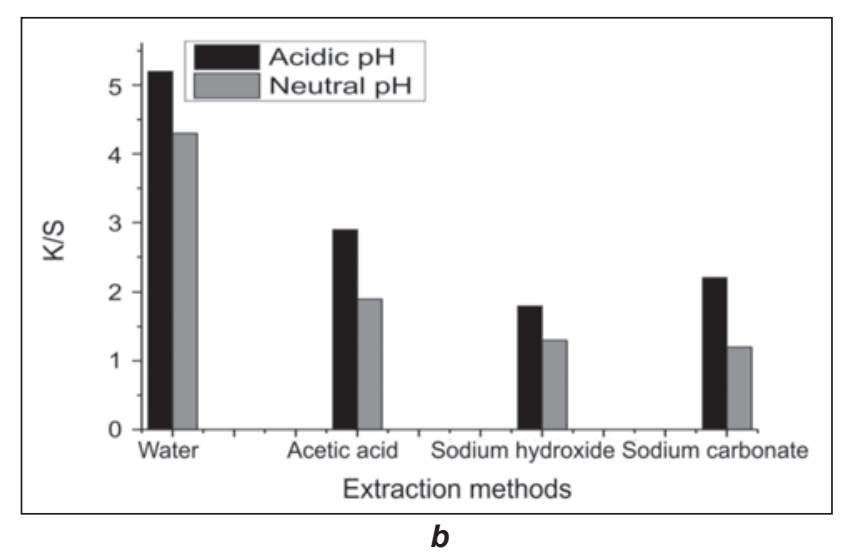

b

Fig. 2. Color strength (K/S) of polyester fabric by: $a$ - ultrasonic, microwave, and $b-$ solvent assisted extraction
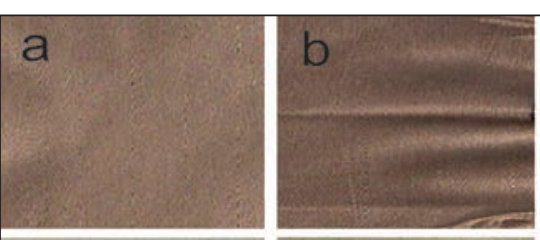

d

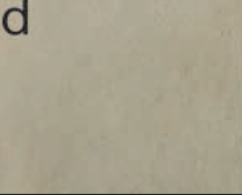

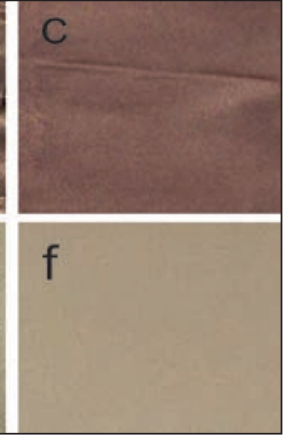
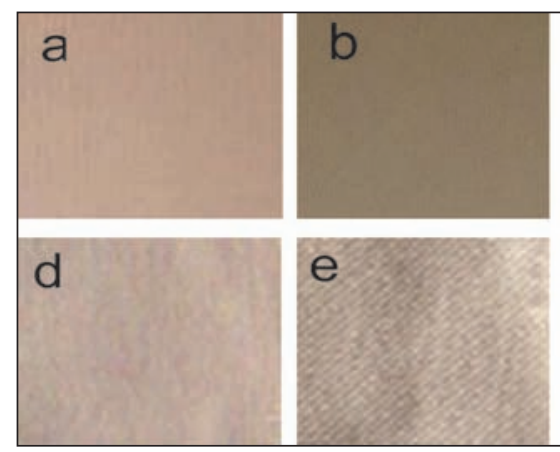

Fig. 3. $a$ - Polyester fabrics dyed at acidic $\mathrm{pH} 4.5-5$ after extraction by: $a$ - water; $b$ - ultrasonic; $c$ - microwave; $d$-sodium hydroxide; $e$ - sodium carbonate; $f$ - acetic acid.

$b$ - Polyester fabrics dyed at neutral $\mathrm{pH} 7$ after extraction by: $a$ - water; $b$ - ultrasonic; $c$ - microwave; $d$-sodium hydroxide; $e$ - sodium carbonate; $f$ - acetic acid

More color strength of microwave extracted polyester fabric is due to the fact that microwaves heating make possible the diffusion of water into the cells of the matrix, leading to better heating and therefore facilitating the transport of compounds into the waterat higher mass transfer rates which was not possible with conventional solvent extraction. Cavitation phenomena as well as mechanical action of ultrasonic energy generate forceful shock waves and power jets to rupture the cell wall of the plant resulted in increased efficiency of extractions as compared to any other solvents used conventionally [17]. Therefore, ultrasonic and microwave extraction of Henna organic dye is acclaimed as an advanced and efficient technique.

\section{Effect of dye bath $\mathrm{pH}$}

Color strength of polyester fabric by all extraction methods at neutral dye bath $\mathrm{pH}(7)$ is less as compared to acidic $\mathrm{pH}(4.5-5)$ as shown in figure $3(\mathrm{~A})$ and $(B)$, respectively. This behavior of Henna dye depends on the ionization and partial solubility of Henna dye. In acidic solution, only $5 \%$ of the lawsone was ionized [29]. However, the used lawsone was replaced by the fibre from solution with the suspended lawsone present as excess of solubility. The partial solubility and very low ionization of Henna dye at acidic $\mathrm{pH}$, made it possible to interact with hydropho- bic polyester fibre (solid solution phenomena). The Henna lawsone chromophore diffused in to the spaces between polyester chains while at the end of the molecule, they wield $\mathrm{OH}$ site that are capable of interacting with polar sites on the substrate. The hydrogen bond is formed between the hydroxyl group of the lawsone molecule and the oxygen of the adjacent polyester fiber chains same like some disperse dyes [30]. On the other hand, at higher dye bath $\mathrm{pH}$, Henna dye ionization increased and it became anionic and repelled by polyester fibre resulted in less dye ability at alkaline $\mathrm{pH}$.

\section{Optimum extraction conditions for Ultrasonic and Microwave \\ Effect of extraction time on the color strength of polyester fabric}

Figure 4 represented the results for the color strength of ultrasonic and microwave extracted Henna dye for different periods of time respectively. It has been observed from the graph that the color strength of polyester fabric increased with increase in the extraction time and reached maximum value of 5.5 and 6 at 30 minutes and 4 minutes for ultrasonic and microwave respectively. This is due to the fact that ultrasonic waves penetrate more deeply into Henna leaves powder resulted in higher mass transfer at 30 minutes until the equilibrium is reached. On the other 


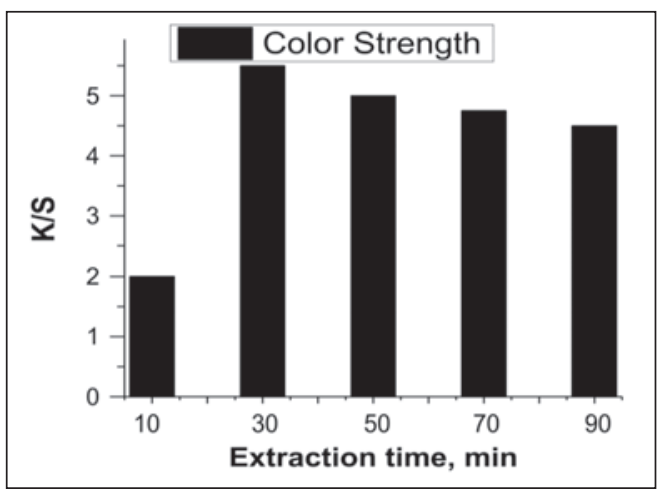

a

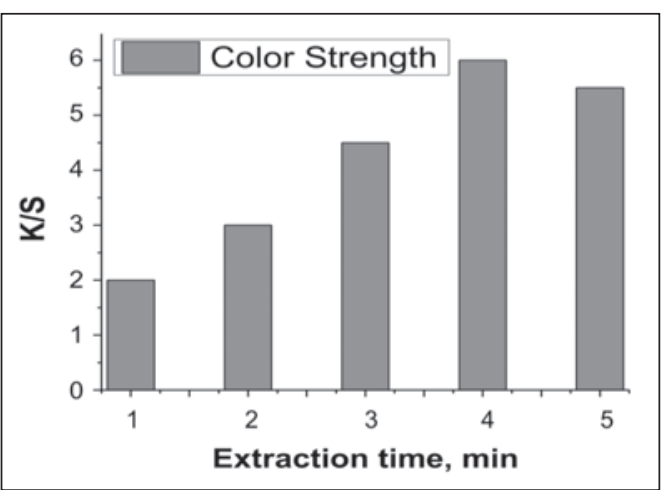

b

Fig. 4. Optimization of time for: $a$ - Ultrasonic extraction; $b$ - Microwave extraction

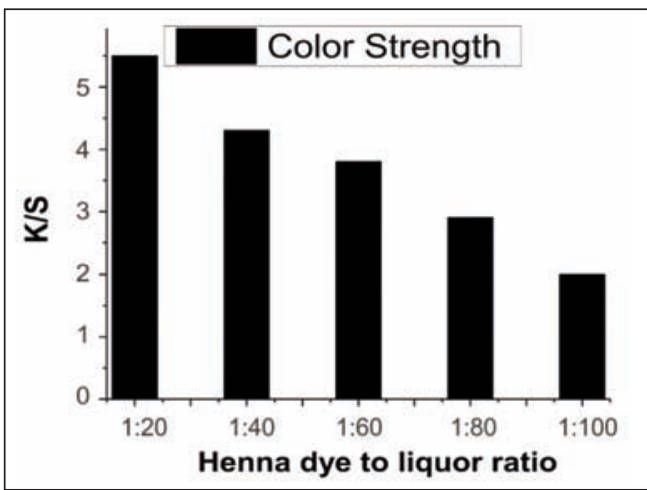

a

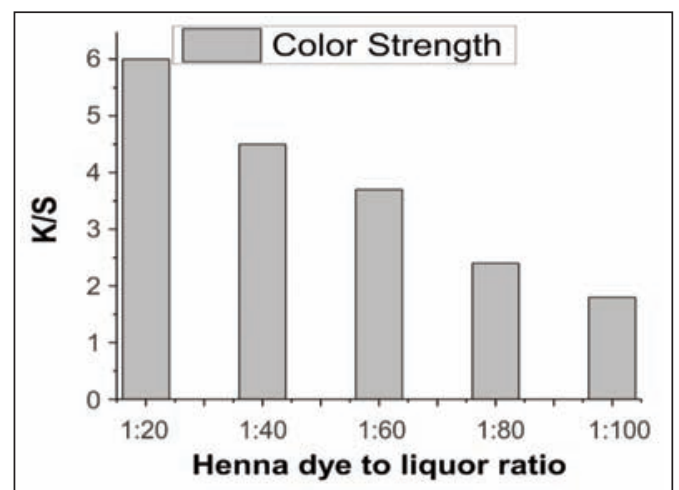

b

Fig. 5. Optimization of Henna dye to liquor ratio for: $a$ - Ultrasonic extraction; $b$ - Microwave extraction

hand, high radiations of microwave are so fast and deep that it needed only 4 minutes for high yield of color component from Henna leaves resulted in deeper shades. A further increase in extraction time resulted in reduction in color strength value by both ultrasonic and microwaves. This may be attributed to the decomposition of coloring component with longer extraction time [31].

\section{Effect of Liquor ratio on the color strength of polyester fabric}

Figure 5 demonstrated the effect of Henna dye to liquor ratio (water) for ultrasonic and microwave respectively. The maximum color strength for both ultrasonic and microwave was achieved at 1:20. As expected, the color strength value of Henna dyed polyester fabric decreased with increasing the liquor ratio and this may be due to the less number of dye molecules available with increased quantity of water for the same weight of fabric.

\section{CONCLUSIONS}

Ultrasonic and microwave assisted extraction of Henna dye has been performed as an energy efficient and solvent free extraction for the dyeing of polyester fabrics. Results revealed that ultrasonic and microwave techniques provided superior color strength properties as compared to results obtained from conventional solvent extraction technique. Ultrasonic and microwave extraction are proved to be efficient in terms of chemicals as these both techniques removed the use of hazardous chemicals in extraction. Ultrasonic and microwave extraction also reduced the time of extraction from hours for conventional solvent extraction methods to 30 minutes and 4 minutes, respectively. The 1:20 liquor ratio gave the optimum color strength on Henna dyed polyester fabric. The presented method of extraction and dyeing of polyester fabric with Henna dye provide a better and proficient route in terms of time, energy, efficiency, and use of unsafe chemicals.

\section{BIBLIOGRAPHY}

[1] Group, W.B., Pollution prevention and abatement handbook. Oil and Gas Development (onshore) Guideline, 1998

[2] Chung, K.-T. andCerniglia, C.E.,Mutagenicity of azo dyes: structure-activity relationships. Mutation Research/ Reviews, In: Genetic Toxicology, 1992, 277(3), pp. 201-220

[3] Carneiro, P.A., et al., Assessment of water contamination caused by a mutagenic textile effluent/dyehouse effluent bearing disperse dyes, In: Journal of Hazardous Materials, 2010, 174(1-3), pp. 694-699 
[4] Das, S., Product safety and restricted substances in apparel, Second Edition ed. 2016, New York: WPI Publishing

[5] Yang, M., et al., Ecological dyeing of silk fabric with Monascus, In: The Journal of the Textile Institute, 2018, pp. 1-6

[6] Karaboyacı, M. and Ş.S. Uğur, Ecological wool dyeing with pulps of lavender, broom, and red wine, In: The Journal of the Textile Institute, 2014, 105 (8), pp. 821-827

[7] Aminoddin Haji, M.N., Sadroddin Qavamnia, S., The use of D-optimal design in optimization of wool dyeing with Juglansregia bark, In: Industria Textila, 2018, 69 (no. 2), pp. 104-110

[8] Sivakumar, V., J. Vijaeeswarri, and J.L. Anna, Effective natural dye extraction from different plant materials using ultrasound, In: Industrial Crops and Products, 2011, 33 (1), pp. 116-122

[9] Sivakumar, V., et al., Ultrasound assisted enhancement in natural dye extraction from beetroot for industrial applications and natural dyeing of leather, In: UltrasonicsSonochemistry, 2009, 16 (6), pp. 782-789

[10] Mansour, R., B. Ezzili, and M. Farouk, The use of response surface method to optimize the extraction of natural dye from winery waste in textile dyeing, In: The Journal of The Textile Institute, 2017, 108 (4), pp. 528-537

[11] Prabhu, K. and M. Teli, Eco-dyeing using Tamarindusindica L. seed coat tannin as a natural mordant for textiles with antibacterial activity, In: Journal of Saudi Chemical Society, 2014, 18 (6), pp. 864-872

[12] Ali, S., T. Hussain, and R. Nawaz, Optimization of alkaline extraction of natural dye from Henna leaves and its dyeing on cotton by exhaust method, In: Journal of cleaner production, 2009, 17 (1), pp. 61-66

[13] Iqbal, J., Bhatti, I.A., and Adeel, S., Effect of UV radiation on dyeing of cotton fabric with extracts of Henna leaves. 2008

[14] Kiumarsi, A., et al., Extraction of dyes from Delphinium Zalil flowers and dyeing silk yarns, In: The Journal of the Textile Institute, 2017, 108 (1), pp. 66-70

[15] Karaboyaci, M., Recycling of rose wastes for use in natural plant dye and industrial applications, In: The Journal of the Textile Institute, 2014, 105 (11), p. 1160-1166

[16] Park, J., et al., Recent advances in ultrasonic treatment: challenges and field applications for controlling harmful algal blooms (HABs), In: Ultrasonics Sonochemistry, 2017

[17] Erdemişsmal, Ö.,Yıldırım, L., and Özdoğan, E., Valorisation of almond shell waste in ultrasonic biomordanted dyeing: alternatives to metallic mordants, In: The Journal of The Textile Institute, 2015, 106 (4), pp. 343-353

[18] Mason, T., Paniwnyk, L., and Lorimer, J., The uses of ultrasound in food technology, In: Ultrasonicssonochemistry, 1996, 3(3), pp. S253-S260

[19] Wang, L. and Weller, C.L., Recent advances in extraction of nutraceuticals from plants, In: Trends in Food Science \& Technology, 2006, 17 (6), pp. 300-312

[20] Febriana, I.D., Gala, S., and Mahfud, M., Ultrasound assisted extraction of natural dye from jackfruit's wood (Artocarpusheterophyllus): The effect of ethanol concentration as a solvent, In: AIP Conference Proceedings, 2017, AIP Publishing

[21] Qadariyah, L., et al., Jackfruit (Artocarpusheterophylluslamk) wood waste as a textile natural dye by micowave-assisted extraction method, In: AIP Conference Proceedings, 2017, AIP Publishing

[22] Nazari, A., Efficient mothproofing of wool through natural dyeing with walnut hull and Henna against Dermestesmaculatus, In: The Journal of the Textile Institute, 2017, 108 (5), pp. 755-765

[23] Alebeid, O.K. and Zhao, T., Review on: developing UV protection for cotton fabric, In: The Journal of the Textile Institute, 2017, 108 (12), pp. 2027-2039

[24] Hasan, M.M., et al., Application of purified lawsone as natural dye on cotton and silk fabric, In: Journal of Textiles, 2015

[25] Baig, G., Indigo dyeing of polyester (PET)-pH effects, In: The Journal of the Textile Institute, 2011, 102(1), pp. 87-92

[26] Azeem, M., et al., Comfort properties of nano-filament polyester fabrics: sensory evaluation, In: Industria Textila, 2018, 69 (1), pp. 3-10

[27] Salehan, N.A.M., Sulaiman, A.Z., and Ajit, A., Effect of temperature and sonication on the extraction of gallic acid from Labisia Pumila (Kacip Fatimah), 2006

[28] Samanta, A.K. and Agarwal, P.,Application of natural dyes on textiles, 2009

[29] Amro, B., James, K., and Turner, T., A quantitative study of dyeing with lawsone, 1993

[30] Khadim Sheikh, H. and Hassan Kazmi, M., Synthesis of novel 1, 2-diol containing azo dyes for polymeric substrates, In: Journal of the Chilean Chemical Society, 2017, 62 (2), pp. 3496-3500

[31] Nagia, F. and El-Mohamedy, R., Dyeing of wool with natural anthraquinone dyes from Fusarium oxysporum, In: Dyes and pigments, 2007, 75 (3), pp. 550-555

Authors:

SAMAD ARAIN RABIA ${ }^{1}$, HUSSAIN PEERZADA MAZHAR ${ }^{1}$ BASHEER ARAIN SAMAD², AYOUB ARBAB ALVIRA ${ }^{3}$

${ }^{1}$ Department of Textile Engineering, Mehran University of Engineering and Technology, Jamshoro, Pakistan

${ }^{2}$ Department of Education, Sindh University, Jamshoro, Pakistan

${ }^{3}$ Department of Organic and Nano Engineering, Hanyang University, South Korea

e-mail: rabia.arain@faculty.muet.edu.pk; mazhar.peerzada@faculty.muet.edu.pk; samama007@yahoo.com; alvira_arbab@yahoo.com

\section{Corresponding author:}

SAMAD ARAIN RABIA

e-mail: rabia.arain@faculty.muet.edu 


\section{Analysis of thermo-physiological comfort properties of $100 \%$ acrylic, acrylic/cotton, acrylic/viscose and acrylic/PES blended woven fabrics}

DOI: $10.35530 / I T .070 .04 .1546$

ARZU YAVAŞCAOĞLU

RECEP EREN

GÜLCAN SÜLE

\section{REZUMAT - ABSTRACT}

Analiza proprietăților de confort termofiziologic ale țesăturilor $100 \%$ acrilice și în amestec acril/bumbac, acril/viscoză și acril/PES

În acest studiu s-au investigat proprietățile de confort termofiziologic ale țesăturilor produse cu fir de bătătură 100\% acril, bumbac, viscoză și PES, precum și în amestec acril/PES, actil/bumbac și acril/viscoză. În acest scop, 35 de țesături diferite au fost realizate din fire acrilice în urzeală și fire de bătătură din acril, bumbac, PES, viscoză, acril/bumbac, acril/viscoză și acril/PES, cu trei desimi diferite de bătătură și legături pânză, diagonal și atlaz. Analiza rezultatelor a arătat că nu S-a observat efectul naturii firului și al desimii bătăturii asupra rezistenței termice. S-a observant că tipul de legătură a avut un efect asupra rezistenței termice, absorbției termice și permeabilității la aer a țesăturilor. Valorile permeabilității la aer ale țesăturilor cu legătură pânză au fost mai mici decât cele ale țesăturilor cu legăturile diagonal și atlaz. Permeabilitatea la aer a scăzut odată cu creșterea desimii firelor de bătătură. Conform evaluării statistice, tipul de fir sau natura firului a avut un efect semnificativ asupra rezistenței la vapori de apă, în timp ce desimea firelor de bătătură și tipul de legătură nu au înregistrat efecte semnificative.

Cuvinte-cheie: acrilic, țesături, confort termofiziologic, rezistența la vapori de apă, permeabilitatea la aer

\section{Analysis of thermo-physiological comfort properties of $100 \%$ acrylic, acrylic/cotton, acrylic/viscose and acrylic/PES blended woven fabrics}

In this study, thermo-physiological comfort properties of woven fabrics produced with $\% 100$ acrylic, cotton, viscose and PES weft as well as acrylic/PES, acrylic/cotton and acrylic/viscose weft mixing were investigated. For this purpose, 35 different fabrics were woven with acrylic warp and acrylic, cotton, PES, viscose, acrylic/cotton, acrylic/viscose and acrylic/PES weft yarns, with three different weft densities and plain, twill and satin weaves. Analysis of results showed that the effect of yarn material and weft density on thermal resistance was not observed. It was seen that weave type had an effect on thermal resistance, thermal absorbtivity and air permeability of the fabrics. Air permeability values of fabrics woven with plain weave were lower than those of satin and twill weaves. The air permeability decreased when weft density was increased. According to statistical evaluation, yarn type or yarn material had significant effect and weft density and weave had no significant effect on water vapour resistance.

Keywords: acrylic; woven fabrics; thermo-physiological comfort;water vapour resistance; air permeability

\section{INTRODUCTION}

Acrylic yarns are widely used in knitted and upholstery fabrics while they are in limited use in woven outwear fabrics. In this study, the usability of acrylic yarns in fine woven fabrics has been examined by weaving fabrics with acrylic warp and a mixture of cotton, viscose and PES weft yarns with acrylic weft. The effect of yarn material, fabric weave and weft density on the thermo-physiological comfort properties of the fabrics, planned to be used as outwear garment, have been systematically investigated. Literature studies on this subject show that there is no comprehensive study made on the comfort characteristics of acrylic and acrylic blended woven fabrics. Accordingly, it is thought that this study will cover a deficiency in the literature.

Comfort is defined as a feeling of "being pleased", that is caused by psychological and physical harmony between the human body and the environment [1]. Clothing comfort is generally classified into two groups as sensory comfort and thermophysiological comfort [2]. Sensory comfort means the neurological perceptions that felt during the mechanical contact of the textile material with the skin [3]. Thermo-physiological comfort concerns the thermal balance maintaining ability of fabric between the human body and the environment and that includes heat and moisture transfer mechanisms that occur in fabric [2].

Some of the studies, where comfort features of woven fabrics are investigated, are as follows. Thermal and water vapour resistance values of woven and knitted fabrics made from different fibers were investigated and it was found that thermal and water vapour resistances values were sorted from big to small for different blend as PES/Wool, PAC, Cotton, PES [4]. Mechanicaland physiological comfort characteristics of low weight suit fabrics were investigated and fabrics woven by wool, silk, linen and their different blends were used in trials and linen blended fabrics had better mechanical comfort than the others, while 
silk and silk blended fabrics provided a good water vapour permeability due to the fine fiber structure causing a large surface area for moisture adsorption and difusion. In addition, it was determined that the water vapour transmission ability of fabrics produced by single-ply yarns was higher than that of the double-ply yarns [5]. In a study using PES, cotton, polypropylene yarns, 3 different weaves (D 3/1 twill, broken twill and herringbone) and 12 different washing methods, 180 different denim fabric types were produced. Fabrics with polypropylene weft had the highest moisture management capacity and conventional cotton denim type, which was produced by using $100 \%$ cotton, had the minimum moisture management capability. This means that these fabrics can keep the human body warm for a longer time in humid and cold weather. Furthermore, it was stated that the weave structure did not affect the thermophysiological comfort properties [6]. In the study of comfort characteristics of garment fabrics, it was found that finishing applications affected the moisture transmission properties of fabrics. Air permeability decreased as the weft density increased. Weft yarn material, weft density and weft yarn number, weave structure, weight, fabric thickness and finishing substance a statistical effect, at the $\alpha=0.05$ reliability level [7]. In another study where the thermal properties of PES, cotton and cotton/PES mixed garment fabrics were investigated, it was shown that the geometric parameters of the fabric, its thickness and porosity, generally affected the thermal insulation, air permeability and water vapour permeability and the fluid transport capability depended on the fiber composition and $50 \%$ cotton $/ 50 \%$ PES blended fabrics almost resembled $100 \%$ cotton fabric. Cotton fabric's higher performance in this field was caused by tight packing during yarn formation [8]. In a study where fabrics used in the field of sports activities were made of PES yarns or natural and regenerated yarns with different properties. According to air permeability results, fabrics containing PES or viscose yarns regardless of considering mass per unit area or thickness values of the fabrics had good air transfer. Using natural fibres such as cotton decreased air permeability of fabrics under the same conditions [9]. Men's jacket is a garment made by combining fabrics, interlining and lining materials. These materials have their own thermal comfort features. Fabrics, interlinings and linings were tested as triple layer. According to the test results, the increase in the number of layers caused the decrease in air and water vapour permeability, and caused increase in the thermal resistance of the material [10].

\section{MATERIALS AND METHODS}

At the beginning of the study, the fiber content of a total of 400 top garment (shirt/blouse) fabrics from 20 different companies on the market were examined. According to the results, the most used fiber type was founds as $100 \%$ cotton with $38 \%$ ratio. This was followed by $100 \%$ PES with $13 \%$ ratio, $100 \%$ viscose with $14 \%$ and cotton/PES blends with $13 \%$ share. From these results, it has been deemed appropriate to use cotton, viscose and PES fibers together with acrylic in the study. Experimental fabrics used in this study were produced under industrial conditions in Boyteks Textile Inc. which is in Bursa Nilüfer Organize Sanayi region. The type of warp (acrylic), warp density (28 threads/cm) and warp yarn count (295 dtex) remained the same. 295 dtex acrylic, cotton, viscose and PES weft yarns were used in the weft. The technical properties of these fabrics are given in table 1.

Terms such as acrylic/PES, acrylic/cotton and acrylic/ viscose used in table 1 indicate that 1 PES weft is inserted after 1 acrylic weft or 1 cotton weft is inserted after 1 acrylic weft during fabric production. Thus, in these fabrics, it was tried to achieve \%50 acrylic ratio in the weft. Fabrics were produced with three different weft density $(13,15$ and 17 threads/cm) and three different weave types (plain, twill $3 / 2$ and satin 1/4). Acrylic warp yarns were sized by synthetic sizing material (PVA) and were subjected to desizing and washing $\left(60^{\circ} \mathrm{C}\right)$ after weaving. No dyeing and other finishing processes were applied to the experimental fabrics.

Thermal resistance, thermal absorbtivity and thickness values of experimental fabrics were measured by Alambeta device (the contact pressure was 200 $\mathrm{Pa})$.

Alambeta instrument (invented by Lubos Hes) simulates, to some extent, the heat flow q, which takes place from human skin to a fabric during a short initial contact. The main feature is a unique sensor that measures the thermal drop between the surfaces of a very thin nonmetallic plate using a multiple differential micro thermocouple. This sensor is $0.2 \mathrm{~mm}$ thick, and on contact with a subject at a different temperature, reaches the maximum heat flow in 0.2 seconds. Thus, it simulates the human skin, which is approximately $0.5 \mathrm{~mm}$ thick and whose neuron ends, located in the middle, also take $0.1-0.3$ second to reach $\mathrm{q}$ as the heat begins to flow through the contacted subject. Having reached this peak value, the heat flow decreases and then stabilizes within 3-15 seconds. Sample thickness $\mathrm{h}$ is automatically measured under constant pressure, which can be preset from 100 to $1000 \mathrm{~Pa}$. The measuring area is $100 \mathrm{~cm}^{2}$. This equipment tests the objective evaluation of warm-cool feeling properties of fabrics. To simulate the real conditions of warm-cool feeling evaluation, the instrument measuring head is heated to $32^{\circ} \mathrm{C}$, which correspond to the average human skin temperature, while the fabric is kept at the room temperature $22^{\circ} \mathrm{C}$. Similarly, the time constant of the heat flow sensor, which measures directly the heat flow between the automatically moved measuring head and the fabrics, exhibit similar value $(0,07 \mathrm{sec})$, as the human skin. Consequently, the full signal response is achieved within $0.2 \mathrm{sec}$ [11].

Air permeability values were measured by SDL Atlas (Model M 021A) air permeability measuring device (the contact pressure was $100 \mathrm{~Pa}$ ) according to TS 


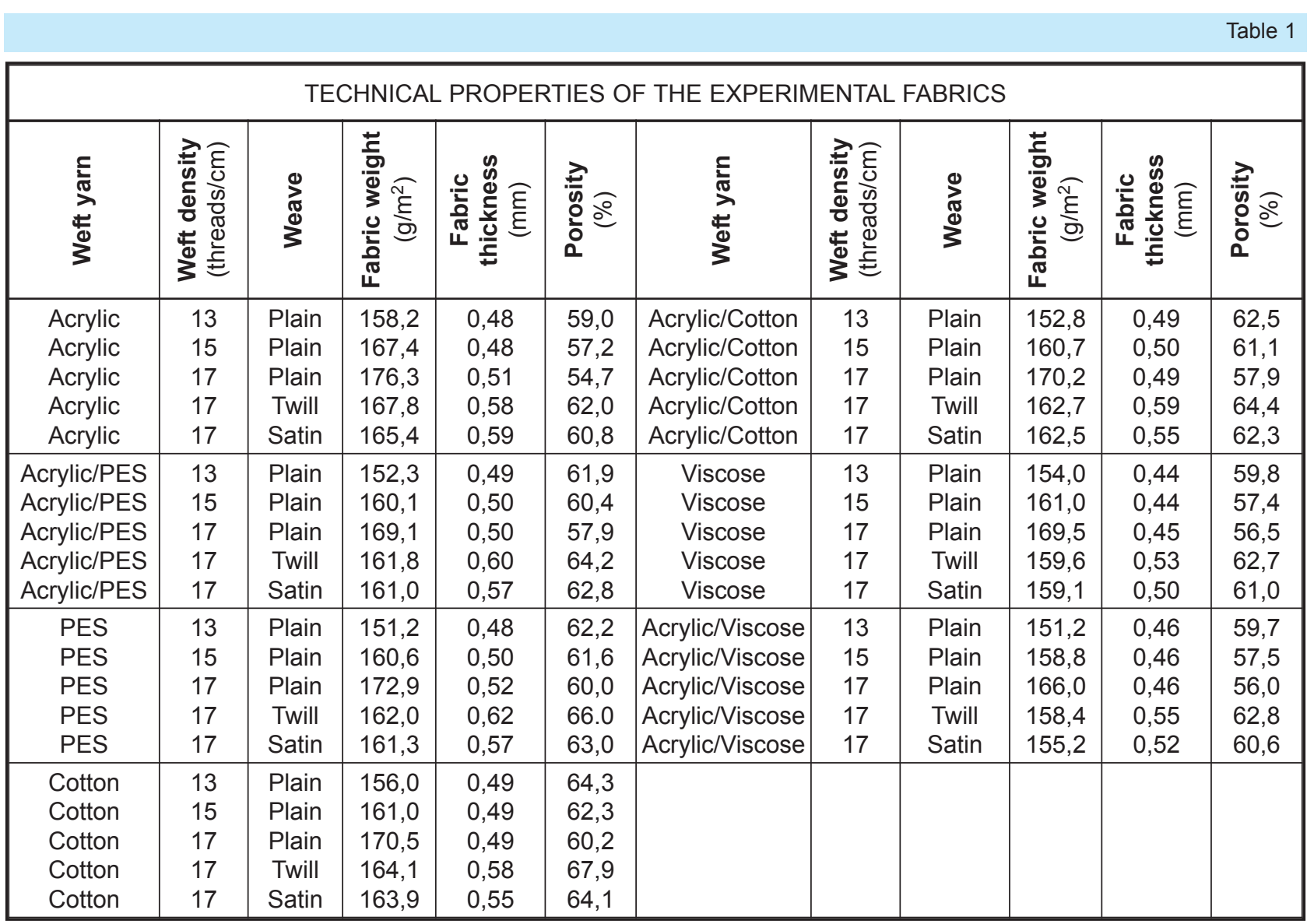

391 EN ISO 9237 standard and the water vapour resistance was measured using Permetest device, according to the ISO EN 11092 standard.

Permetest apparatus (invented by Lubos Hes) measures the amount of heat passing through a thermal model of the human skin. The porous sweating surface of the device simulates the skin and records the cooling heat flow caused by perspiration. The fabric sample to be measured is placed on a measuring head over semi-permeable foil and exposed to parallel air flow at a velocity of $1 \mathrm{~m} / \mathrm{s}$. As with all the skin model systems, the measurements are carried out under isothermal conditions (here $23^{\circ} \mathrm{C}$ ). This isothermal principle involves the temperature of the skin model surface, air temperature and fabric temperature, when the fabric is kept in direct thermal contact with the skin model surface. It does not refer to the fabric surface temperature, when there is an air gap between the skin model surface and the tested fabric. The computer connected to the apparatus determines the evaporative resistance Ret and the thermal resistance Rct of textile fabrics in a similar way to that as well as the RWVP (or relative negative heat flow responsible for the cooling of the body). These values serve to reflect the thermo-physiological properties of textile fabrics and garments. The higher the RWVP, the lower the Ret, and the better the thermal comfort of the garment. Due to the very short measuring time, which normally does not exceed 3 min (the steadystate is indicated by the computer), the fabric mass remains mostly unchanged during the measurements. Fabrics were measured in a laboratory with controlled atmosphere of $21-23^{\circ} \mathrm{C}$ temperature and a $50-55 \%$ relative humidity [12].

In this study, porosity of woven fabrics was calculated using three-dimensional (3-D) unit pore cell models developed by Turan [13] and was given in table 1. Volumetric porosity of fabrics was calculated by Equation 1 and yarn diameter used in this equation was determined using Equation 2 developed by T.F. Peirce [14].

$$
\begin{aligned}
P(\%) & =\frac{p_{1} p_{2} t-\pi / 4\left(d_{1}^{2} l_{1}+d_{2}^{2} l_{2}\right)}{p_{1} p_{2} t} \\
d & =2 \sqrt{\frac{V_{y}}{\pi N 100}}(\mathrm{~cm})
\end{aligned}
$$

where:

$p$ is distance between two yarn centers;

$t$ - fabric thickness;

I - yarn length within the pore cell;

$V_{y}$ - yarn specific volume;

$N$ - metric yarn count;

1 and 2 indices represent warp and weft yarns respectively.

Yarn specific volume is given as $V_{y}=1 /\left(0,59 \rho_{f}\right)$ where 0,59 is packing constant of fibres in the yarn and $\rho_{\mathrm{f}}$ is fibre density.

Effect of fiber type which was used with acrylic yarns, weave type and weft density were evaluated statistically by using SPSS 16 program. Factor analysis of variance (One-Way ANOVA) was performed to examine the effect of the variables and Tukey HSD and 
TAMHANE tests from multiple comparison tests were applied to determine which groups differ statistically from other groups. The $F$ statistic $\left(F_{s}\right)$ values in the analysis of variance were compared with values of $F_{0.05, n, t}$ on the table and the importance of the factor was determined accordingly. Significance level (sig.) was evaluated at $p<0,05$ level.

\section{RESULT AND DISCUSSION}

Thermal resistance $\left(R, m^{2} K / W\right)$ (in stable condition), is a value, which is calculated by dividing the temperature difference between two sections of material and the heat flow rate between the sections and a power which resist against heat transfer. Garments with higher thermal resistance values are preferred for protection from cold, while those with low thermal resistance properties are preferred over hot days [15]. The thermal resistance values of the fabrics are shown in figure 1. According to the measured data, the thermal resistance values of the fabrics vary between 11,4 and $15,6 \mathrm{~m}^{2} \mathrm{~K} / \mathrm{W} \times 10^{-3}$. The highest thermal resistance value was observed on the woven fabric in twill weave with PES weft yarn and in density of 17 threads $/ \mathrm{cm}$. Since the thermal resistance of the fabric is directly proportional to the thickness of the fabric, it is expected that this fabric, which is the thickest fabric among all fabrics, has the highest thermal resistance. In general, when looking at the results, the thermal resistance values of fabrics woven with all types of weft yarns, in three different weft density and plain weave, are close to each other. However, the thermal resistance values of fabrics woven in twill and satin weave are higher than the thermal resistance values of fabrics woven in plain weave. The reason for this is that the fabrics woven in twill and satin weave are thicker than the fabrics woven in plain weave.

When the thermal resistance values of plain weave fabrics which are woven by adding PES, cotton and viscose weft yarns to the acrylic weft yarn are compared with the thermal resistance values of the fabrics woven by $100 \%$ acrylic yarn, the thermal resistance values of these fabrics are close to each other. When the same comparison is made in twill and satin weave fabrics, it is observed that the addition of cotton, PES, and viscose weft to acrylic reduces the thermal resistance of fabrics, especially in satin weave fabrics compared to $100 \%$ acrylic weft fabrics. The reason for this is that the thicknesses of these fabrics are lower than $100 \%$ acrylic weft fabric.

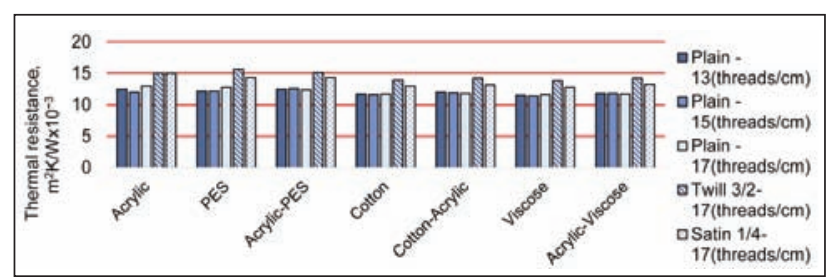

Fig. 1. Thermal resistance values of the fabrics

To statistically examine the effect of weft type, weft density and weave type on the thermal comfort properties of trial fabrics used in the study, One Way Variance Analysis (One-way ANOVA) and Multiple Comparison (Post-Hoc) tests were performed in the SPSS program. Kolmogorov Smirnov (normality) test was performed to determine whether the data provided parametric test conditions. The test result Sig(p) was found to be bigger than 0.05 and the normal distribution was determined. When the equation of error variances (Levene) test variance was not homogenous (Sig. $<0.05)$ in the multiple comparison table; Tamhane and when it was homogeneous (Sig. > 0,05), Tukey HSD test results were evaluated. The results of statistical relation test between weft type, weave type and weft density and variables are given in table 2. The significance level of the relationship between the variables is determined by looking at the significance level (Sig.(p)). A statistically significant relationship is assumed when the Sig.(p) value is less than 0.05 [16]

When the thermal resistance measurement results of the fabrics were evaluated statistically (table 2), it was found that the weave type had an effect on the thermal resistance and the weft type and weft density had no effect on the thermal resistance. According to table 3, when statisticall difference between weave types is examined there is significant difference between plain and twill and satin weave fabrics but no significant difference between twill and satin weave fabrics.

Thermal absorbtivity (b, Ws $1 / 2 / \mathrm{m}^{2} \mathrm{~K}$ ) (temporarily), is the instantaneous heat flow that occurs when two parts at different temperatures come into contact with each other. Thermal absorbtivity means the hot, cold sense of the garment, that is, the first perception sense of the fabric at the first contact. That is the numerical value of the heat transfer rate between the fabric and the skin. If the thermal absorbtivity is low, the fabric feels warm at first contact; If it is high, it

ANALYSIS OF VARIANCE (ANOVA) P-VALUES FOR THERMO-PHYSIOLOGICAL COMFORT PROPERTIES OF THE FABRICS

\begin{tabular}{|l|c|c|c|c|c|c|c|c|}
\hline & \multicolumn{2}{|c|}{ Thermal resistance } & \multicolumn{2}{c|}{ Thermal absorbtivity } & \multicolumn{2}{c|}{ Air permeability } & \multicolumn{2}{c|}{ Water vapour resistance } \\
\cline { 2 - 9 } & $\mathbf{F}$ & Sig. & $\mathbf{F}$ & Sig. & $\mathbf{F}$ & Sig. & $\mathbf{F}$ & Sig. \\
\hline Weft type & 0,955 & 0,473 & 2,462 & 0,49 & 0,331 & 0,915 & 12,903 & 0 \\
\hline Weave & 22,091 & 0 & 13,893 & 0 & 103,786 & 0 & 0,312 & 0,736 \\
\hline Weft density & 0,373 & 0,694 & 2,335 & 0,125 & 27,150 & 0 & 1,066 & 0,365 \\
\hline
\end{tabular}


EFFECT OF WEAVING TYPE ON THERMAL RESISTANCE, THERMAL ABSORBTIVITY AND AIR PERMEABILITY, RESULTS OF THE MULTIPLE COMPARISON (POST-HOC) TESTS

\begin{tabular}{|c|c|c|c|c|c|c|c|c|c|c|c|c|c|c|}
\hline \multicolumn{15}{|c|}{ Multiple comparisons } \\
\hline 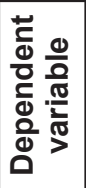 & 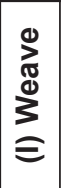 & 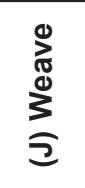 & 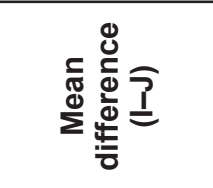 & i் & 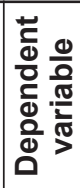 & 音 & 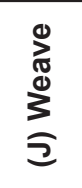 & 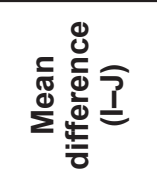 & i் & 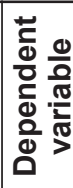 & $\begin{array}{l}0 \\
\substack{\pi \\
ٍ} \\
\vdots\end{array}$ & $\begin{array}{l}\sum_{\pi}^{0} \\
\stackrel{0}{0} \\
3\end{array}$ & 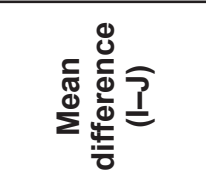 & வ் \\
\hline \multicolumn{15}{|c|}{ Tukey HSD } \\
\hline \multirow{6}{*}{ 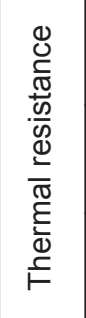 } &.$\subseteq$ & twill & $-2,45714286^{*}$ & 0 & \multirow{6}{*}{ 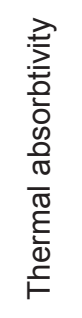 } & \multirow{2}{*}{$\frac{\frac{.}{\pi}}{\frac{\pi}{2}}$} & twill & $20,8571^{*}$ & 0 & \multirow{6}{*}{ 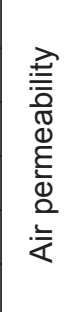 } & \multirow{2}{*}{$\frac{\frac{5}{\pi}}{2}$} & twill & $-225,285714^{*}$ & 0 \\
\hline & $\frac{0}{2}$ & satin & $-1,58571429^{*}$ & 0,001 & & & satin & $15,5714^{*}$ & 0,004 & & & satin & $-261,142857^{*}$ & 0 \\
\hline & \multirow{2}{*}{$\overline{\bar{z}}$} & plain & $2,45714286^{*}$ & 0 & & \multirow{2}{*}{$\overline{\overline{3}}$} & plain & $-20,8571^{*}$ & 0 & & \multirow{2}{*}{$\overline{\overline{3}}$} & plain & $225,285714^{*}$ & 0 \\
\hline & & satin & 0,87142857 & 0,078 & & & satin & $-5,2857$ & 0,421 & & & satin & $-35,857143$ & 0,190 \\
\hline & \multirow{2}{*}{ 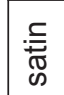 } & plain & $1,58571429^{*}$ & 0,001 & & \multirow{2}{*}{ 离 } & plain & $-15,5714^{*}$ & 0,004 & & \multirow{2}{*}{ 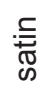 } & plain & $261,142857^{*}$ & 0 \\
\hline & & twill &,- 87142857 & 0,078 & & & twill & 5,2857 & 0,421 & & & twill & 35,857143 & 0,190 \\
\hline
\end{tabular}

gives cold feeling. Especially in cold days, this parameter, which gives the feeling of comfort to the wearer at the time of first wearing, changes according to the thermal conductivity, density and specific heat values of the material [17].

The thermal absorbtivity values of the fabrics are shown in figure 2. According to the data, the thermal absorbtivity values of the fabrics vary between 131 and $175 \mathrm{Ws}^{1 / 2} / \mathrm{m}^{2} \mathrm{~K}$. When the results are examined, the highest thermal absorbtivity values are in fabrics which are produced by cotton/acrylic and viscose weft yarns, in plain weave. This result means that this fabric will make feel cool, in the first contact with them. Among the experimental results, the lowest thermal absorbtivity value is in the fabrics which were woven by PES weft yarn, in twill and satin weave. When density of these fabrics is calculated taking into account the weight and thickness values, two fabrics have the lowest density value in terms of fabric density. One of the parameters affecting the thermal absorbtivity of the fabric is the fabric density. As the fabric density increases, the thermal absorbtivity value increases. In PES wefted fabrics, as the fabric density is lower, the thermal absorbtivity of fabrics is lower too.

When the graphic in figure 2 is examined, it is generally seen that the thermal absorbtivity values of fabrics woven in plain weave, are higher than the thermal absorbtivity values of fabrics woven in twill and satin weave. Accordingly, among fabrics woven by all weft types at a weft density of 17 threads/cm, it can be concluded that plain weave fabrics make feel colder than twill and satin fabrics.

When the thermal absorbtivity measurement results of the experimental fabrics are evaluated statistically (table 2), it is seen that the weave type has an effect on the thermal absorbtivity, the used weft type and the weft density have no effect on the thermal absorbtivity. According to the results of the Tukey test (table 3), it was seen that there was a meaningful difference between plain and twill and satin weave, but not a significant diference between twill and satin weave.

Air permeability $\left(1 / \mathrm{m}^{2} / \mathrm{sec}\right)$ is the quantity of passing air in unit time from unit area, under a certain pressure difference between two surfaces of a material. It describes the passing ability of air through the fiber, yarn and fabric structure. This parameter, which allows easier transfer of heat and determines the breathability feature, has an important place among the thermal comfort features [18]. Air permeability values of the experimental fabrics shown in figure 3 . Air permeability values vary between $89-440 \mathrm{l} / \mathrm{m}^{2} / \mathrm{s}$. When the graph is examined, it is seen that the highest air permeability value belongs to the satin weave fabric by PES weft yarn. The air permeability of fabrics is affected by the porosity of the fabrics. Fabrics with high porosity allow more air to pass through. When the porosity values of the fabrics woven by PES weft yarn are examined (table 1), it is seen that

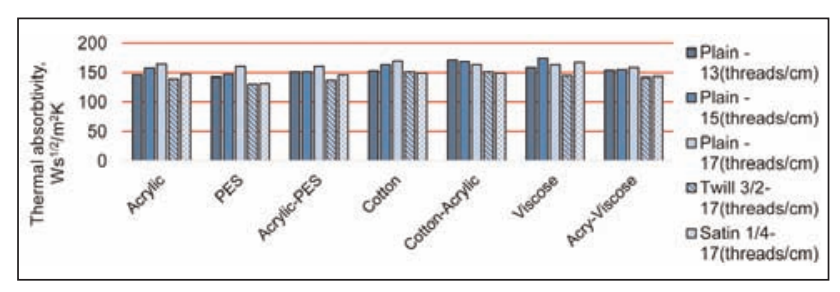

Fig. 2. Thermal absorbtivity values of the fabrics

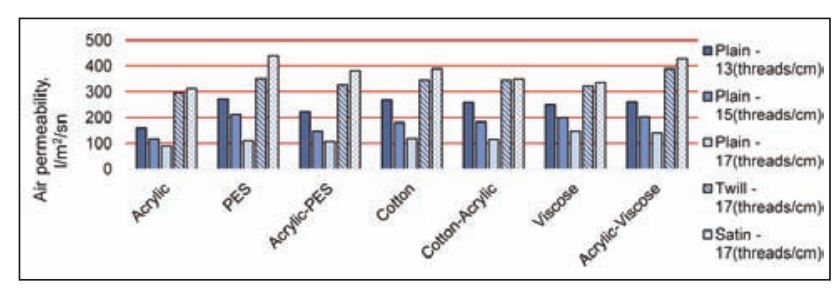

Fig. 3. Air permeability valuesof the fabrics 


\begin{tabular}{|c|c|c|c|c|c|}
\hline \multicolumn{6}{|c|}{$\begin{array}{l}\text { EFFECT OF WEFT DENSITY ON AIR PERMEABILITY, RESULTS OF THE MULTIPLE COMPARISON } \\
\text { (POST-HOC) TEST }\end{array}$} \\
\hline \multicolumn{6}{|c|}{ Multiple comparisons } \\
\hline \multirow{7}{*}{ Tukey HSD } & $\begin{array}{l}\text { Dependent } \\
\text { variable }\end{array}$ & (I) Weft density & (J) Weft density & $\begin{array}{l}\text { Mean difference } \\
(I-J)\end{array}$ & Sig. \\
\hline & \multirow{6}{*}{ Air permeability } & \multirow{2}{*}{13} & 17 & $124,2857^{*}$ & 0 \\
\hline & & & 15 & $67,5714^{*}$ & 0,002 \\
\hline & & \multirow{2}{*}{17} & 13 & $-124,2857^{*}$ & 0 \\
\hline & & & 15 & $-56,7143^{*}$ & 0,009 \\
\hline & & \multirow{2}{*}{15} & 13 & $-67,5714^{*}$ & 0,002 \\
\hline & & & 17 & $56,7143^{*}$ & 0,009 \\
\hline
\end{tabular}

they are the most porous fabrics together with the cotton fabrics.

According to figure 3, the fabric which was woven by acrylic weft yarn, in plain weave and at 17 threads $/ \mathrm{cm}$ weft density, has the lowest air permeability value. The porosity value of this fabric is lower than the porosity values of fabrics woven with other weft types. The low porosity of the fabric has reduced air permeability by making this fabric more resistant to air passage.

When the air permeability measurement results were statistically evaluated, it was found that the influence of the weft type used on fabrics on the air permeability was not significant but the weft density and the air permeability of the weave type were significant (table 2). The air permeability decreased as the weft density increased in plain weave fabrics. The reason for this is that as the weft density increases, the porosity of the fabric decreases. When the effect of the weft density on air permeability was examined statistically (table 4), as Sig. values are smaller than 0.05 , it can be said that there is a significant difference between all density values. When the effect of the applied weave type on the air permeability is examined, it is seen that the air permeability of the fabrics woven by plain weave is lower than the fabrics woven by twill and satin weave. Previous studies showed that fabrics woven with plain weave are more resistant to air passage than fabrics woven by other weaves with the same yarn count and densities. Hence, in our study, that the air permeability values of the fabrics woven with the twill and satin weaves are higher than the air permeability values of the fabrics woven with the plain weave, supports this result [18]. When the effect of the weave type on the air permeability was statistically analyzed (table 3 ), while the effect of the plain weave structure on the air permeability was statistically significant compared to the twill and satin weave, there was no statistically significant difference between the effect of the twill and satin weave air permeability.

Water vapour resistance (Ret) $\left(\mathrm{m}^{2} \mathrm{~Pa} / \mathrm{W}\right)$ is the resistance of the material to the flow of water vapour. It is the ratio of water vapour pressure difference between to surfaces of a material to heat flow in unit area in the direction of heat flow.
The relative water vapour permeability of a textile surface is expressed as the ability of vapour transferring formed by sweating from the body to the external environment. If the water vapour permeability of the fabric is low, so if the steam resistance is high, the heat stored in the body and consequently the sweat can't be removed ant that cause to an unpleasant sensation [19].

According to the results of the water vapour resistance measurements of the experimental fabrics (figure 4), the fabrics which have the lowest water vapour resistance are woven usingcotton and viscose weft yarn. The fabrics with the highest water vapour resistance are those woven with acrylic and PES weft yarn. This can be explained by lower porosity of acrylic weft fabrics and high porosity of cotton weft fabrics. On the other hand, PES and cotton weft fabrics and acrylic and viscose weft fabrics have porosity values very close to each other. But, PES weft fabrics have higher water vapour resistance compared to cotton weft fabrics and acrylic weft fabrics have higher water vapour resistance compared to viscose wetf fabrics. When available literature is examined on relative water vapour permeability (\%), contradicting results are encountered about effect of fabrics produced by hydrophobic and hydrophilic fibers on relative water vapour permeability (\%). Some of the researchers point out that hydrophilic fabrics increases relative water vapour permeability (\%) [20-22] while the others conclude that hydrophobic fabrics have higher relative water vapour permeability (\%) [23-25]. In this research, fabrics produced with hydrophilic weft yarns (viscose and cotton) show higher relative water vapour permeability velower water vapour resistance than fabrics produced with hydrophobic weft yarns (PES and acrylic). As a result type of fiber used in the production of fabrics had

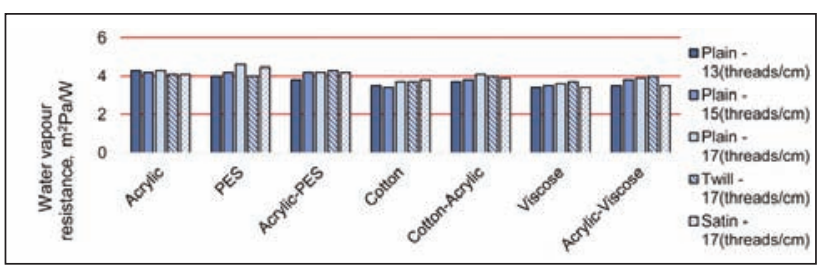

Fig. 4. Water vapour resistance values of the fabrics 
EFFECT OF WEFT TYPE ON WATER VAPOUR RESISTANCE, RESULTS OF THE MULTIPLE COMPARISON (POST-HOC) TESTS

\begin{tabular}{|c|c|c|c|c|c|c|c|c|c|}
\hline \multicolumn{10}{|c|}{ Multiple comparisons } \\
\hline \multirow[t]{2}{*}{ 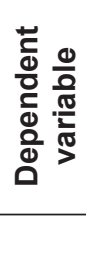 } & 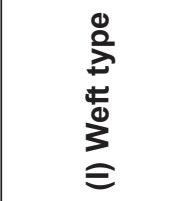 & 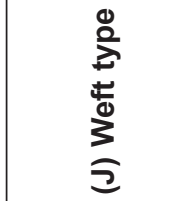 & 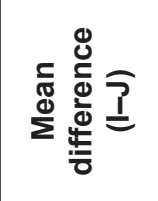 & क் & 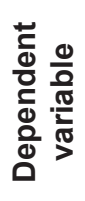 & 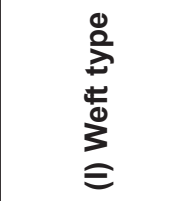 & 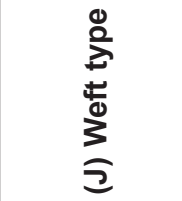 & 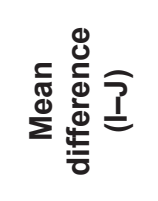 & $\frac{\dot{\theta}}{\dot{\infty}}$ \\
\hline & \multicolumn{4}{|c|}{ Tamhane } & & \multicolumn{4}{|c|}{ Tamhane } \\
\hline \multirow{24}{*}{ 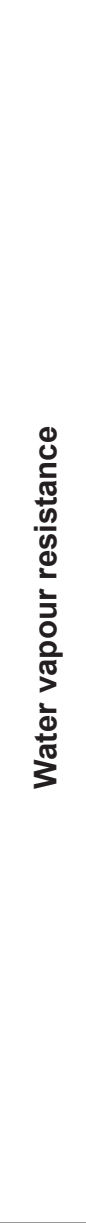 } & \multirow{6}{*}{ Acyrlic } & 1PES-1Acr & 0,06000 & 1,000 & \multirow{24}{*}{ 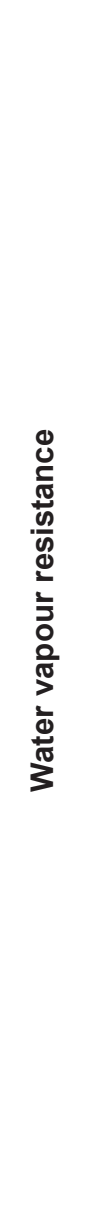 } & \multirow{6}{*}{ 1Co.-1Acr. } & Acrylic & $-0,30000$ & 0,181 \\
\hline & & PES & $-0,03400$ & 1,000 & & & 1PES-1Acr & $-0,24000$ & 0,764 \\
\hline & & Cotton & $0,58000^{*}$ & 0,007 & & & PES & $-0,33400$ & 0,552 \\
\hline & & 1Co-1Acr & 0,30000 & 0,181 & & & Cotton & 0,28000 & 0,416 \\
\hline & & Viscose & $0,68000^{*}$ & 0 & & & Viscose & 0,38000 & 0,071 \\
\hline & & 1Vis-1Acr & 0,46000 & 0,151 & & & 1Vis-1Acr & 0,16000 & 0,997 \\
\hline & \multirow{6}{*}{ 1PES-1Acr. } & Acrylic & $-0,06000$ & 1,000 & & \multirow{6}{*}{ Viscose } & Acrylic & $-0,68000^{*}$ & 0 \\
\hline & & PES & $-0,09400$ & 1,000 & & & 1PES-1Acr & $-0,62000^{*}$ & 0,012 \\
\hline & & Cotton & $0,52000^{*}$ & 0,041 & & & PES & $-0,71400^{*}$ & 0,023 \\
\hline & & 1Co.-1Acr & 0,24000 & 0,764 & & & Cotton & $-0,10000$ & 1,000 \\
\hline & & Viscose & $0,62000^{*}$ & 0,012 & & & 1Co-1Acr & $-0,38000$ & 0,071 \\
\hline & & 1Vis.-1Acr & 0,40000 & 0,325 & & & 1Vis.-1Acr & $-0,22000$ & 0,913 \\
\hline & \multirow{6}{*}{ PES } & Acrylic & 0,03400 & 0,000 & & \multirow{6}{*}{ 1Vis.-1Arc. } & Acrylic & $-0,46000$ & 0,151 \\
\hline & & 1PES-1Acr & 0,09400 & 1,000 & & & PES-Acr & $-0,40000$ & 0,325 \\
\hline & & Cotton & $0,61400^{*}$ & 0,046 & & & PES & $-0,49400$ & 0,207 \\
\hline & & 1Cot.-1Acr & 0,33400 & 0,552 & & & Cotton & 0,12000 & 1,000 \\
\hline & & Viscose & $0,71400^{*}$ & 0,023 & & & 1Co-1Acr & $-0,16000$ & 0,997 \\
\hline & & 1Vis.-1Acr & 0,49400 & 0,207 & & & Viscose & 0,22000 & 0,913 \\
\hline & \multirow{6}{*}{ Cotton } & Acrylic & $-0,58000^{*}$ & 0,007 & & & & & \\
\hline & & 1PES-1Acr & $-0,52000^{*}$ & 0,041 & & & & & \\
\hline & & PES & $-0,61400^{*}$ & 0,046 & & & & & \\
\hline & & 1Co.-1Acr & $-0,28000$ & 0,416 & & & & & \\
\hline & & Viscose & 0,10000 & 1,000 & & & & & \\
\hline & & 1Vis.-1Acr & $-0,12000$ & 1,000 & & & & & \\
\hline
\end{tabular}

effect on water vapour resistance more pronounced than fabric porosity in this study.

When the results ofwater vapour resistance are evaluated statistically, while the influence of the weft type used in fabrics on water vapour resistance was significant, the effect of the weft density and weave type on water vapour resistance is not found as significant (table 2). According to the multiple comparison (Tamhane) test presented in table 5 , it is seen that there is a statistical difference between water vapour resistance values of acrylic and cotton, as well as acrylic and viscose weft fabrics. There is no statistical difference in terms of water vapourresistance values between PES and acrylic weft fabrics.

\section{CONCLUSIONS}

In this study, the effects of acrylic yarns, which are not used in fine woven fabrics, on the thermo-physiological comfort properties of woven fabrics are investigated. For this purpose, woven fabrics have been produced by warp yarn acrylic and by weft yarns acrylic, PES, cotton, viscose, acrylic/PES, acrylic/cotton and acrylic/viscose at three different weft densities and weave structures. Thermal comfort, air permeability and water vapour resistance properties of woven fabrics have been tested.

The highest value of thermal resistance was observed on the woven fabric using twill weave with PES weft yarn. This fabric is the thickest of all experimental fabrics. The thermal resistance values of fabrics woven in twill and satin weaveswere higher than the thermal resistance of fabrics woven in plain weave. The reason for this is that the twill and satin weave fabrics are thicker than the fabrics woven in plain weave. When the thermal resistance measurement results are statistically evaluated, it is seen that the weave type has an effect on thermal resistance 
and weft type and weft density have no effect on thermal resistance. Moreover, it's found that there is a significant difference between plain weave and twill and satin weave but no significant difference between twill and satin weave.

Fabrics which were woven by cotton/acrylic and viscose weft yarns, in plain weave, had the highest thermal absorbtivity values and fabrics which were woven by PES weft yarn in twill and satin weave had the lowest thermal absorbtivity values. This means that in the first contact, cotton/acrylic and viscose weft fabrics will give a cool feeling, and PES weft fabrics will give a warm feeling. It is generally seen that the thermal absorbtivity values of fabrics woven in plain weave, are higher than those of fabrics woven in twill and satin weaves. Accordingly, among fabrics woven by all weft types, it can be concluded that plain weave fabrics make feel colder than twill and satin fabrics. When the results were evaluated statistically, it was found that the weave type had an effect on thermal absorbtivity, the weft type used and the weft density had no effect on thermal absorbtivity. In addition, the result is that plain weave fabrics give a colder feel than twill and satin fabrics.

Air permeability measurement results show that the highest air permeability value belongs to fabric woven by PES weft yarn and in satin weave and the lowest air permeability value belongs to fabric woven by acrylic weft yarn and in plain weave. Fabrics with high porosity allow more air to pass through. When the porosity values of the fabrics woven with PES weft yarn are considered, it is seen that they are the most porous fabrics together with the cotton fabrics. Porosity of acrylic weft fabrics is found to be lower than all the other fabrics. When the results are statistically evaluated, the effect of the weft type used on fabrics on air permeability was not significant but effect of the weft density and weave were significant. Furthermore, it has been found that air permeability of fabrics woven in plain weave is lower than that of fabrics woven in twill and satin weave.

The results of the water vapourresistancemeasurement; the fabrics woven by cotton weft yarn have the lowest water vapourresistance, the fabrics having the highest water vapourresistance; woven by acrylic weft yarn and in twill and satin weave. In the statistical evaluations, it was found that the effect of the weft type used in fabrics on thewater vapour resistance was significant and effect of the weft density and weave type were not significant.

\section{ACKNOWLEDGEMENT}

This research is financially supported by BAP Project (No: OUAP (MH)-2014/10), funded by Uludag University, Turkey.

\section{BIBLIOGRAPHY}

[1] Slater, K., The assesment of comfort, In: Journal of the Textile Institute, 1985, 77 (3), pp. 157-171

[2] Saville, B.P., Physical testing of textiles, Woodhead Publishing Limited, 2007, Cambridge, England

[3] Li, Y., The science of clothing comfort, In: Textile Progress, 2001, 31 (1-2), pp. 1-135

[4] Guanxiong, Q., Yuan, Z., Zhongwei, W., Jianli, L. \& Jie, Z., Comfort in knitted fabrics, In: International Man-Made Fibers Congress Proceeding, 1991, Portugal, pp. 34-38

[5] Behera, B. K. \& Mishra, R., Comfort properties of non-conventional light weight worsted suiting fabrics, In: Indian Journal of Fibre\& Textile Research, 2007, 32

[6] Mangat, M., M., The effect of moisture and finishing on thermal comfort and selected mechanical properties of denims with a portion of synthetic fibres, Ph.D. Research, Technical University, 2012, Liberec, Czech Republic

[7] Erenler, A.,Giysi amaçlı dokunmuş kumaşlarda konfor özelliklerinin incelenmesi ve tahminlenmesi, Çukurova Üniversitesi, Fen Bilimleri Enstitüsü, Tekstil Mühendisliği Anabilim Dalı, Doktora Tezi, 2013, Adana

[8] Li, M., Wu, Y., Chen, C. \& Du, Z., Characterization of planter press-comfort performance of warp-knitted spacer fabrics, In: Textile Recearch Journal, 2016, doi:10.1177/0040517516679152

[9] Unal, P.G. \& Ureyen, M.E., Mechanical and permeability properties of sportech fabrics, In: Industria Textila, 2016, 67(3), pp.151-156

[10] Akcagun, E., Yılmaz, A., Ö.Ceviz, N. \& Mazarı A., Investigating the thermal comfort properties of men's jacket as single and multiple layered material, In: Industria Textila, 2017, 68(6), pp. 458-463

[11] Hes, L., Araujo, M. \& Djulay, V., V. Effect of mutual bonding of textile layers on thermal insulation and thermal contact properties of fabric assemblies, In: Textile Research Journal, 1996, 66 (4), pp. 245-250

[12] Hes, L. \& Araujo, M., Simulationof the effect of air gaps between the skin and a wet fabric on resulting cooling flow, In: Textile Research Journal, 2010, 80 (14), pp. 1488-1497

[13] Turan, R. B., Kumaşların geçirgenlik özellikleri ile yapısal ve geometrik özellikleri arasındaki ilişkiler. Dokuz Eylül Üniversitesi, Fen Bilimleri Enstitüsü, Tekstil Mühendisliği Anabilim Dalı, Doktora Tezi, 2012, pp. 382

[14] Peirce, F. T., The geometry of cloth structure, In: Journal of the Textile Institute, 1937, 28(3), pp. 45-96

[15] Frydrych, I., Dziworska, G. \& Bilska, J., Comparative analyses of the thermal Insulation properties of fabrics made of natural and man-made cellulose fibres, In: Fibers \& Textiles in Eastern Europe, 2002, 10, pp. 40-44

[16] Kayri, M., Araştırmalarda gruplar arası farkın belirlenmesine yönelik çoklu karşılaştırma (post-hoc) teknikleri. Fırat Üniversitesi Sosyal Bilimler Dergisi, 2009, 19/1, pp. 51-64 
[17] Hes, L., Optimisation of shirt fabrics' composition from the point of view of their appearance and thermal comfort, In: International Journal of Clothing Science and Technology, 1999, 11 (2/3), pp. 105-115

[18] Backer, S., The relationship between the structural geometry of a textile fabric and its physical properties. Part IV: Interstice geometry and air permeability, In: Textile Research Journal, 1951, 21, pp. 703-714

[19] Ertekin, G. \& Marmaralı, A., Askı ve atlamanın düz örgü kumaşların ısıl konfor özelliklerine etkileri. In: Tekstilve Mühendis, 2011, 83, pp. 21-26

[20] Das, B., Das, A., Kothari, V., Fanguiero, R. \& Araujo, M., Moisture flow through blended fabrics-effect of hydrophilicity, In: Journal of Engineered Fibers and Fabrics, 2009, 4 (4), pp. 20-28

[21] Das, B., Das, A., Kothari, V.K., Fangueiro, R. \& Araujo, M., Studies on moisture transmission properties of PV-blended fabrics, In: The Journal of the Textile Institute, 2009, 100 (7), pp. 588-597

[22] Kandhavadivu, P., Ramachandran, T. \& Geetha Manohari, B., Moisture transmission behavior of micro fibre blended fabrics, In: Journal of Textile Association, 2011, 71 (6), pp. 311-315

[23] Knight, B., A., Hersh, S.P. \& Brown, P., Moisture characteristics of some knit fabrics made from blend yarns, In: Textile Research Journal,1970, 40 (9), pp. 843-851

[24] Hassan, M., Qashqary, K., Hassan, H.A., Shady, E. \& Alansary, M., Influence of sportswear fabric properties on the health, In: Fibres\& Textiles in Eastern Europe, 2012, 20 (4), pp. 82-88

[25] Varshney, R.K., Kothari, V.K. \& Dhamija, S., A study on thermophysiological comfort properties of fabrics in relation to constituent fibre fineness and cross-sectional shapes, In: Journal of the Textile Institute, 2010, 101 (6), pp. 495-505

\section{Authors:}

\section{ARZU YAVAŞCAOĞLU1 ${ }^{1}$, RECEP EREN² ${ }^{2}$ GÜLCAN SÜLE ${ }^{2}$}

${ }^{1}$ Yalova University, Yalova Vocational School, 77100, Yalova, Turkey e-mail: arzu.yavascaoglu@yalova.edu.tr

2Uludağ University, Faculty of Eng., Textile Eng. Department, 16059, Nilüfer, Bursa,Turkey e-mail: erecep@uludag.edu.tr, gulcan@uludag.edu.tr

Corresponding author:

\section{GÜLCAN SÜLE}

e-mail: gulcan@uludag.edu.tr 


\section{Optimization of fabric drape measurement based on 3D model}

DOI: 10.35530/IT.070.04.1552

AZMAT HUSSAIN

WANG XIN

TAYYAB NAVEED

IQBAL WAQAR

DANISH IQBAL

YUEQI ZHONG

ZHICAI YU

\section{REZUMAT - ABSTRACT}

\section{Optimizarea determinării drapajului materialelor textile pe baza modelului 3D}

Drapajul este o caracteristică importantă a materialului textil, corelându-se în principal cu rigiditatea acestuia. Această caracteristică este evaluată obiectiv cu un indicator, respectiv coeficientul de drapaj (DC). Coeficientul de drapaj se calculează pe baza suprafaței bidimensionale de proiecție a probei cu drapaj tridimensional (3D). În acest studiu, se evaluează modelul de drapaj tridimensional (3D) și se prezintă o nouă bază a suprafeței cu funcție de secționare. Suprafața propusă a fost calculată cu ajutorul unui plan orizontal, care a secționat modelul de drapaj 3D (curba de secțiune), chiar deasupra celui mai înalt punct al curbei reale limită. Coeficientul de drapaj modificat (MDC) a fost comparat cu cel inițial DC, în ceea ce privește rezistența la încovoiere. Rezultatele au demonstrat că rezistența la încovoiere înregistrează valori optime cu MDC, în comparație cu DC. Rezultă astfel că, MDC este mai eficient în evaluarea drapajului materialelor textile.

Cuvinte-cheie: rezistența la încovoiere, proiecție drapaj, coeficient de drapaj modificat, funcție de secționare, drapaj tridimensional

\section{Optimization of fabric drape measurement based on 3D model}

Drapability is an important characteristic of fabric appearance, mainly correlates to its stiffness. It is evaluated objectively with a dominant indicator, drape coefficient (DC). Drape coefficient is based on the two-dimensional projection-area of three-dimensional (3D) draped sample. In this study, three dimensional (3D) drape-model is evaluated and a new basis of the area is revealed with slice function. The proposed area was calculated using a horizontal plane that cut the $3 D$ drape-model (slice curve) just above the highest point of actual boundary-curve. Modified drape coefficient (MDC) was compared with DC against bending stiffness. The results demonstrate that the bending stiffness has better conformance with MDC than that of DC. This implies that MDC is more effective in evaluating fabric drapability.

Keywords: bending stiffness, drape projection, modified drape coefficient, slice function, three dimensional drape

\section{INTRODUCTION}

Fabric drape is a complex and three dimensional (3D) phenomenon of fabric appearance and appeal. It is influenced dominantly with bending stiffness [1-2] among many other properties of fabric. Fabric drape is evaluated objectively with 'drape coefficient' (DC) [3], however, equivalent DC is possible for fabrics having different bending rigidities. Therefore, DC is unable to characterize the fabric 3D drape [4].

Traditionally, fabric and garment designers assess its drape subjectively in an informal manner. Apparel fashion-designers do extensive efforts to visualize the actual appearance of fabric drape. Initially, they create a pattern on certain fabrics and make a garment to fit on a mannequin, with continuous corrections [5]. In 1950 Chu et al. quantified fabric drapability into an objective value DC [6]. Cusick reinvestigated the method with the same measuring principle i.e. two dimensional (2D) projection from 3D fabric drape in the more efficient way [7].

Further investigations have been focused on improving the efficacy and digitization of Cusick method by the use of techniques like photovoltaic cells [8], image processing [9-13], fractal dimensions [14-15], Fourier Expansion [16] and computer simulation [17], offered efficacy, measuring reliability and different drape indicators. These indicators are based on drape area and perimeter, radius, node, profile and 3D simulation. Among them, DC is the most widely used, which is the ratio of projected area of fabric sample hung under the gravitational field over a circular support disk to the area if it is completely rigid. Albeit, these techniques are more efficient in time-saving and reliability than that of the conventional paper tracing method (i.e. Cusick method), the measurements are based on a $2 \mathrm{D}$ projection of $3 \mathrm{D}$ fabric deformation. Therefore, DC is unable to fully characterize 3D drape-shape [14].

Emerging technologies have been used to determine the 3D drape of fabrics [18]. For instance, 3D scanned images contain vast information and allow further analysis of fabric drape. Scientists [19] explored the 3D scanned images for DC however, the improvement in the measuring accuracy for soft fabrics was only $5 \%$. It has been argued that fabric 
shear and bending were the potential fabric properties which cause shape variations within drape and folds [8,13], and final sample drape geometry is attained by the support of adjacent sides. However, due to boundary heights fluctuations [20] support to the adjacent sides vary below the highest point of 3D drape-model boundary. This doubts the consideration of projected area for the actual drape evaluation. Thus, there is a need to reinvestigate the complex drape phenomenon to develop new 3D indicator by considering a suitable area for drape evaluation.

In this study, a modification in the measurement of $\mathrm{DC}$ is proposed by the analysis of $3 \mathrm{D}$ drape model. Multiple depth cameras were used to reconstruct the 3D drape-model. Evaluation of these drape models revealed a new area instead of projection area, based on which the modification in the previous drape indicator (DC) is proposed. The performance of modified drape-coefficient (MDC) is also compared with the DC against bending stiffness.

\section{MATERIALS AND METHODS}

Thirteen different commercial fabrics (woven) were collected with a wide range of thickness, GSM, yarn count and fabric densities. The specifications of the fabric samples are listed in table 1. All the samples were evaluated objectively in the standard ambient conditions i.e. $20 \pm 2^{\circ} \mathrm{C}$ temperature, and $65 \pm 2$ R.H \%. Self-made drape-meter was used to reconstruct the 3D fabric drape model (figure 1). The drape meter consisted of a supporting disk and a pillar. The disk has $12 \mathrm{~cm}$ diameter, similar to the commercially available XDP-1. The fabric samples (240 mm diameter) were hanged freely over the support disk under the gravitational force.

Table 1

\begin{tabular}{|c|c|c|c|c|}
\hline \multicolumn{5}{|c|}{ FABRIC CHARACTERISTICS } \\
\hline $\begin{array}{c}\text { Sample } \\
\text { ID }\end{array}$ & $\begin{array}{c}\text { Density } \\
\text { (numbers } \\
\text { of warp \& } \\
\text { weft /inch) }\end{array}$ & $\begin{array}{c}\text { Thickness } \\
\text { (mm) }\end{array}$ & $\begin{array}{c}\text { Mass per } \\
\text { unit area } \\
\left(\mathrm{g} / \mathrm{m}^{2}\right)\end{array}$ & $\begin{array}{c}\text { Yarn count } \\
\text { warp/weft } \\
\text { (Tex) }\end{array}$ \\
\hline S1 & $84 * 64$ & 0.63 & 300 & $24 * 24$ \\
\hline S2 & $80 * 80$ & 0.24 & 105 & $8.3^{*} 8.3$ \\
\hline S3 & $80 * 58$ & 0.33 & 240 & $22 * 20$ \\
\hline S4 & $70 * 82$ & 0.31 & 267 & $25^{\star} 20$ \\
\hline S5 & $60 * 60$ & 0.66 & 435 & $50 * 38$ \\
\hline S6 & $108^{*} 90$ & 0.31 & 277 & $22 * 19$ \\
\hline S7 & $43 * 38$ & 0.46 & 300 & $50 * 50$ \\
\hline S8 & $68 * 54$ & 0.37 & 234 & $28 * 28$ \\
\hline S9 & $44 * 38$ & 0.45 & 299 & $59 * 59$ \\
\hline S10 & $51 * 47$ & 0.44 & 304 & $54 * 54$ \\
\hline $\mathrm{S} 11$ & $52 * 58$ & 0.29 & 208 & $28 * 28$ \\
\hline S12 & $52 * 53$ & 0.28 & 190 & $34 * 28$ \\
\hline S13 & $54^{\star} 50$ & 0.43 & 258 & $28^{*} 28$ \\
\hline
\end{tabular}

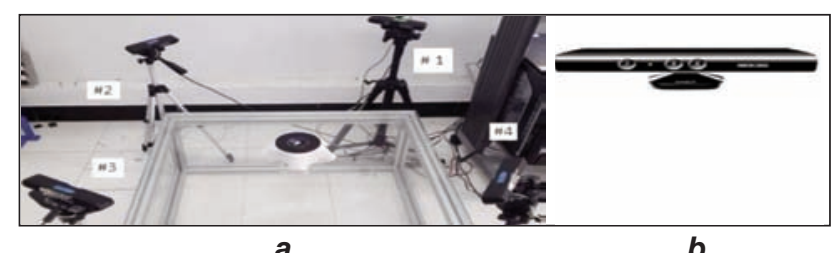

a

b

Fig. 1. Arrangement of multiple depth-cameras for 3D drape scan: $a$ - arrangement of four multiple depth cameras and drape-meter; $b$ - depth camera

\section{Slice area}

\section{Reconstruction of 3D Drape-Model}

To reconstruct the 3D drape models, fabric samples were placed on drape-meter (figure 1) and scanned at different locations by multiple depth cameras using a method developed in our earlier research [21-22]. We made a modification on this method with four depth cameras instead of six. After extracting the points cloud from multiple depth cameras, drape images were processed in Geomagic software for denoising. The average dimensional error of the final fabric model was around 2-3 $\mathrm{mm}$.

\section{Three-dimensional drape evaluation}

As an effort to benefit from the 3D drape information, the evaluation of 3D drape models using slice function is elaborated in figure 2 . The details of slice function are described in our earlier research [21]. This method used two dimensional planes parallel to horizontal axis over the 3D drape model at various vertical positions. In this research, we considered ten vertical positions on the 3D drape model as shown in dotted red lines (figure 2,b,c). Three dimensional drape model in figure 2, a displays its cross-sectional view with slice curves in figure 2,b. Figure 2, c shows the front view where top slice stays $5 \mathrm{~mm}$ below the highest vertical point and bottom slice at the top point of 3D boundary curve of drape model. The projection boundary of the 3D draped model is shown in solid line in figure 2, $b, c$.

For the performance assessment of modified drape indicator, bending-stiffness was calculated using Stiffness Tester objectively [23]. A rectangular fabricstrip was placed on a horizontal support of the stiffness tester and slid in the direction of its length. The fabric increasing part hanged under its own weight to a specific angle $\left(41.5^{\circ}\right)$. The overhang length $(L)$ both in weft and warp direction was noted as a mean value of five samples each. Bending length $(c)$ is then given by Eq. 1

$$
c \approx \frac{L}{2}
$$

\section{RESULTS AND DISCUSSIONS}

\section{Slice area}

Three-dimensional drape models were explicitly analyzed with slice function to identify the optimum area for the modification in drape evaluation. The shapes of slice curves obtained at various vertical heights on 


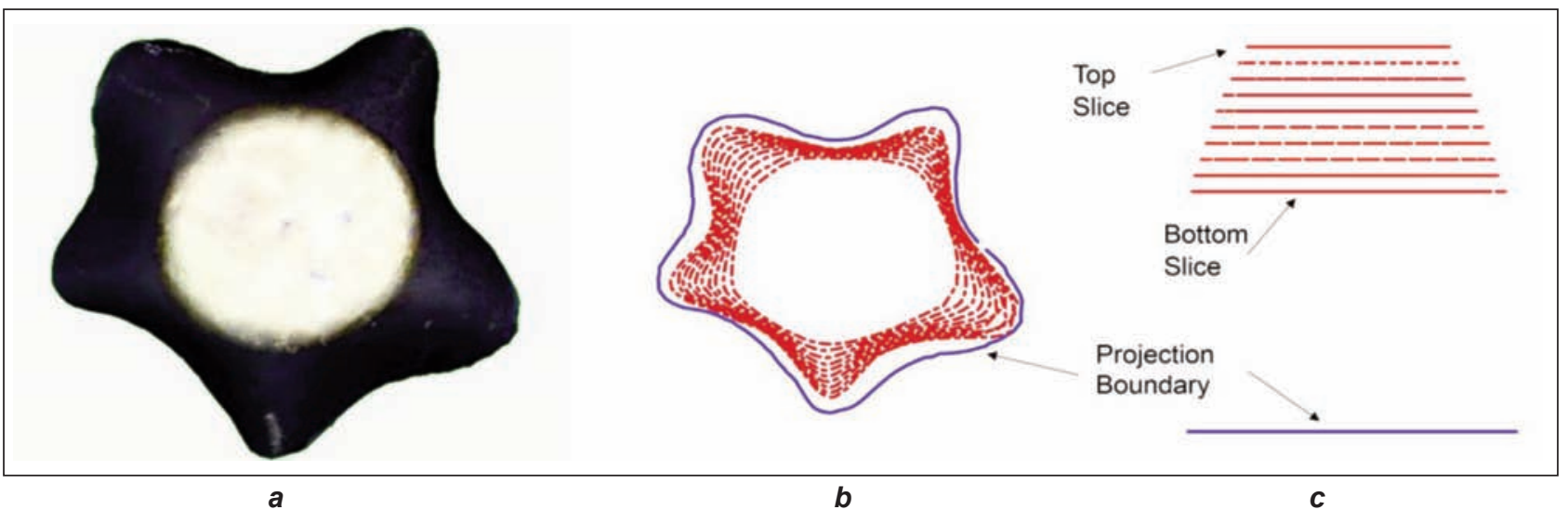

Fig. 2. Slice curves and projection boundary of 3D drape model: $a-3 D$ drape model; $b-$ cross-sectional view of slices; $c$ - front view of slices

the draped model are shown in figure 3. The figure shows the gradual change in slice shapes from the first (top) slice to last (bottom) slice. As the slice position descended (top to bottom), the area was increased; at the same time, node positions and their numbers remained the same. These fundamental characteristics of 3D fabric drape were determined at the time of initial node generation (i.e., top slices). Though, refinement in node shape was achieved as the position of slice curves descended over the 3D drape model. Maximum refinement in the drape shape was obtained at the $10^{\text {th }}$ slice position (bottom slice). Thus, the bottom slice was chosen for further objective evaluation of fabric drape. However, below the $10^{\text {th }}$ (bottom) slice position, due to variations in the 3D drape-model boundary heights, fabric edges lose support from the adjacent sides and ultimately shape relaxation at the projected boundary-curve was noted. This effect is shown between $10^{\text {th }}$ (bottom) slice and projected boundary curve of the draped sample in figure 3 . The impact is noted more intensified for stiffer fabrics (figure 4).

(S)

Fig. 3. Change in slice shapes at various descent positions on 3D drape model

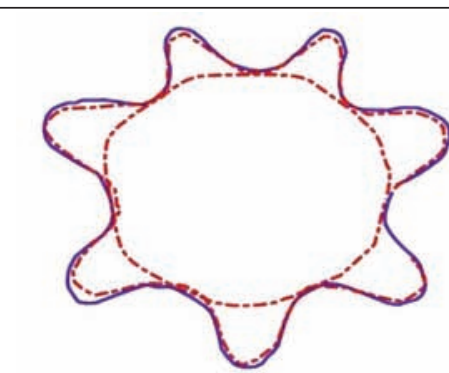

Soft

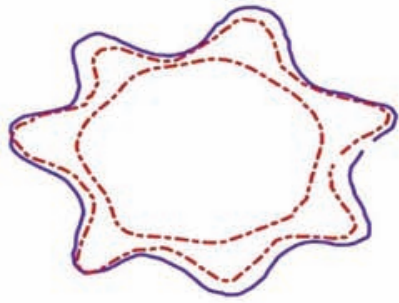

Moderate rigid

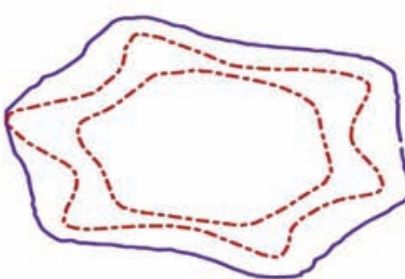

Rigid

Fig. 4. Comparison of top slice, bottom slice and projection curves for the soft, moderate rigid and rigid fabrics; dotted-line for top and bottom slice curves and solid line for projection curve 


\begin{tabular}{|c|c|c|c|c|c|c|c|c|c|}
\hline \multicolumn{10}{|c|}{ ANALYSIS OF DRAPE AREA } \\
\hline \multirow{2}{*}{$\begin{array}{c}\text { Sample } \\
\text { ID }\end{array}$} & \multirow{2}{*}{$\begin{array}{l}\text { Class } \\
\text { name }\end{array}$} & \multirow{2}{*}{$\begin{array}{l}\text { Class } \\
\text { label }\end{array}$} & \multicolumn{2}{|c|}{ Range $\left(\mathrm{cm}^{2}\right)$} & \multicolumn{2}{|c|}{ Mean $\left(\mathrm{cm}^{2}\right)$} & \multirow{2}{*}{$\begin{array}{l}\text { Standard } \\
\text { deviation } \\
\text { (MDC) }\end{array}$} & \multirow{2}{*}{ MDC* } & \multirow{2}{*}{ DC } \\
\hline & & & BSA* $^{*}$ & $\mathrm{PA}^{*}$ & BSA & PA & & & \\
\hline S1 & \multirow{2}{*}{ Soft } & 1.0 & \multirow{2}{*}{5.2} & \multirow{2}{*}{25.2} & \multirow{2}{*}{71.2} & \multirow{2}{*}{89.1} & 1.27 & 20.2 & 22.6 \\
\hline $\mathrm{S} 2$ & & 1.0 & & & & & 1.23 & 21.7 & 30.0 \\
\hline S3 & \multirow{7}{*}{$\begin{array}{l}\text { Moderate } \\
\text { rigid }\end{array}$} & 2.0 & \multirow{7}{*}{14.5} & \multirow{7}{*}{70.1} & \multirow{7}{*}{103.2} & \multirow{7}{*}{160.6} & 2.84 & 31.5 & 49.1 \\
\hline S4 & & 2.0 & & & & & 2.49 & 28.0 & 46.4 \\
\hline S5 & & 2.0 & & & & & 0.25 & 32.0 & 41.9 \\
\hline S6 & & 2.0 & & & & & 0.79 & 31.5 & 40.8 \\
\hline S7 & & 2.0 & & & & & 2.53 & 28.9 & 39.8 \\
\hline S8 & & 2.0 & & & & & 1.49 & 32.3 & 60.4 \\
\hline S9 & & 2.0 & & & & & 2.41 & 29.4 & 52.7 \\
\hline $\mathrm{S} 10$ & \multirow{4}{*}{ Rigid } & 3.0 & \multirow{4}{*}{52.8} & \multirow{4}{*}{42.7} & \multirow{4}{*}{142.1} & \multirow{4}{*}{213.7} & 1.59 & 35.3 & 68.8 \\
\hline S11 & & 3.0 & & & & & 2.94 & 43.1 & 59.8 \\
\hline S12 & & 3.0 & & & & & 1.49 & 38.2 & 56.2 \\
\hline $\mathrm{S} 13$ & & 3.0 & & & & & 1.71 & 50.9 & 66.9 \\
\hline
\end{tabular}

${ }^{*} \mathrm{BSA}=$ Bottom Slice Area; PA = Projection Area; MDC = Modified Drape Coefficient.

\section{Bottom slice area and projection area}

Table 2 shows the analysis of drape area for both bottom slice and boundary curve (projection) of the entire sample. The samples were divided into three classes (soft, moderate rigid and rigid) on the basis of stiffness (strip method). Ranges of the bottom-slice area (BSA) were observed in distinct limits among the different fabric classes. Soft fabrics ranged $5.29 \mathrm{~m}^{2}$, where semi-rigid and rigid fabrics ranged $14.57 \mathrm{~cm}^{2}$ and $52.84 \mathrm{~cm}^{2}$ respectively. On the other hand, projection area (PA) overlapped among the different classes of fabric stiffness. Projection area ranged from $135.31 \mathrm{~cm}^{2}$ to $205.32 \mathrm{~cm}^{2}\left(70.01 \mathrm{~cm}^{2}\right)$ and $191.05 \mathrm{~cm}^{2}$ to $233.75 \mathrm{~cm}^{2}\left(42.7 \mathrm{~cm}^{2}\right)$ for semirigid and rigid classes respectively. Projection area compared to the BSA has wider range in soft and moderate rigid fabrics; where, BSA has shown narrow range in different fabric classes.

Variation in mean BSA values compared to PA also revealed narrow range for all fabric classes. On the other hand, averages for both drape areas i.e. BSA and PA have shown distinct values for each fabric class. Modified drape coefficient (MDC) based on BSA was computed according to Eq. 2 along with DC as shown in table 2. Both of these drape indicators (MDC and DC) have shown different trends, as their corresponding areas, shown in figure 5 .

$$
\text { Modified drape coefficient }(M D C)=\frac{B S A}{S A} \times 100
$$

where

$B S A$ is bottom slice area;

$S A$ - original sample area.

Overall comparison of BSA and PA is shown in figure 5. The trend between BSA \& PA from softer (Sample No. 1-2) to rigid fabrics (Sample No. 10-13) is shown in the figure with increasing area. Importantly, the change in trend for both drape areas (BSA and PA)

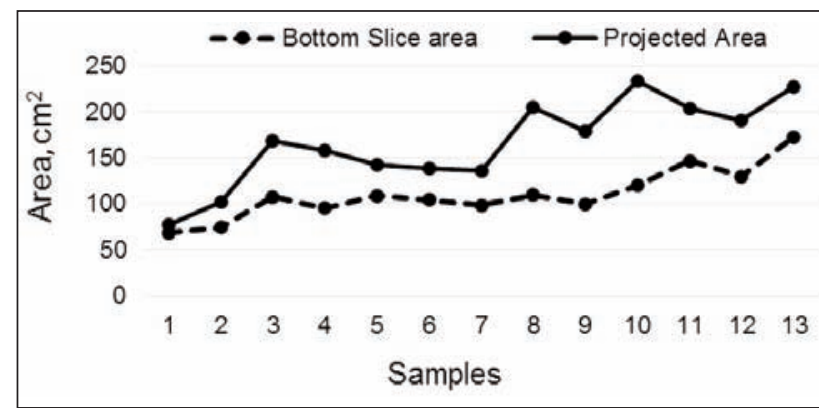

Fig. 5. Overall comparison of Bottom-slice and Projection area

was non-conforming with each other. Though most of the observations have shown same trend, however, some samples (No. 5 and 11) moved in the reverse directions. Additionally, BSA graph line in figure 5, divided itself into three distinct regions whereas, PA due to higher fluctuations could never. Contrary to BSA, PA in rigid class is superseded by semi-rigid class: as the PA value of sample no. $8\left(205.32 \mathrm{~cm}^{2}\right)$ in moderate rigid class was higher than sample no. $11\left(202.90 \mathrm{~cm}^{2}\right)$ and $12\left(191.05 \mathrm{~cm}^{2}\right)$ in rigid class. It means, DC misclassifies fabrics based on PA. These results are supported by the findings of [24, 25], they have shown different DCs for different materials. This was due to the support variations that occur in fabric adjacent-sides below the highest point of the boundary. lin the case of BSA, support is consistent with fabric adjacent sides and consequently, fewer fluctuations were detected; this proves that BSA is a better reference for the actual realization of fabric drape.

\section{Three dimensional drape evaluation}

Three-dimensional space provides more options and information to evaluate fabric drape. Therefore, MDC based on BSA is evaluated and compared with conventional drape indicator DC against the bending 


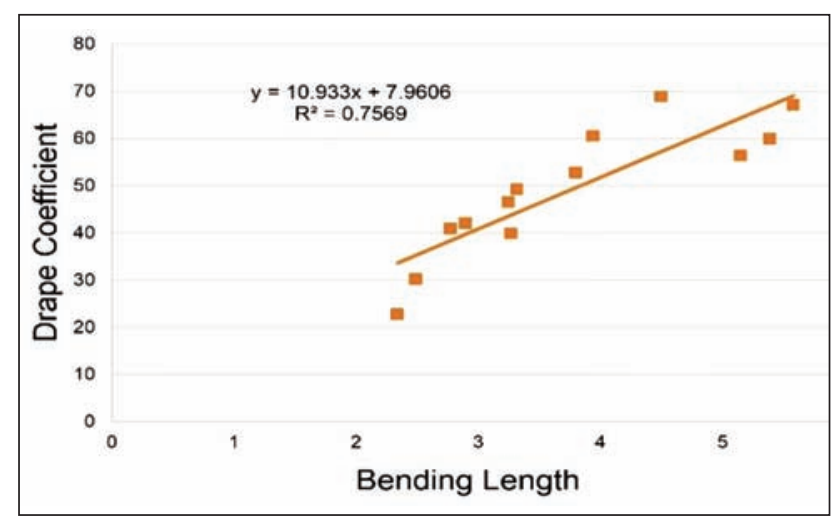

a

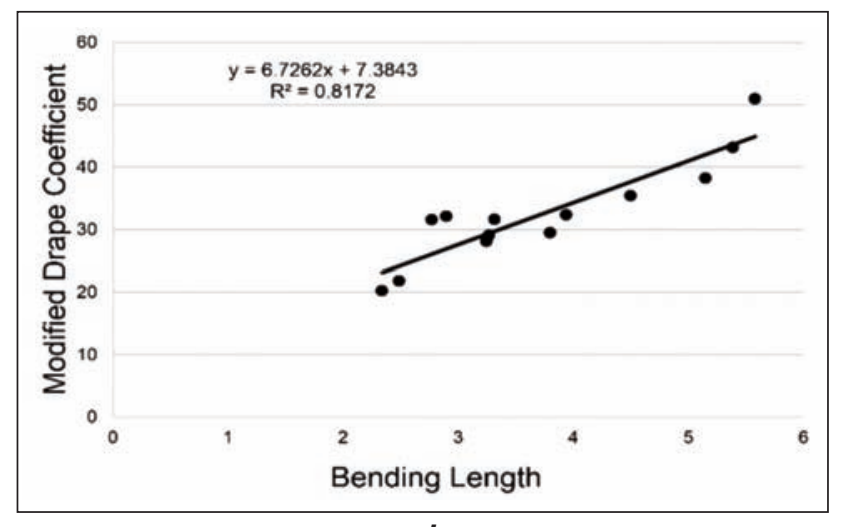

$\boldsymbol{b}$

Fig. 6. Comparison of $a$ - Drape Coefficient and $b$-Modified Drape Coefficient against bending length measured by the strip method

stiffness. Comparison of DC and MDC against the bending stiffness (strip method) is shown in figure 6 . Figure $6, b$ indicates that MDC conforms more to the data compared to DC with R-square values 0.81 . Figure 6 , a with R-square value 0.75 shows more variations for the conventional DC compared to MDC. These results are according to the findings of [26] who stated the effect of stiffness on fabric drape.

This proves that the fabric drape conforms more to bottom slice area (at the highest point of the actual boundary curve) than the projection area. Results of MDC demonstrate the optimization in fabric drape measurement compared to the previously proposed DC. Thus, MDC is a more reliable drape indicator.

\section{CONCLUSIONS}

In this research, 3D drape model has been evaluated with slice function and modification in traditional drape coefficient is proposed successfully. Optimization in the proposed DC is based on bottom slice-area, instead of the projection area. Modified Drape Coefficient increases with the increase of fabric stiffness. The results proved that bending stiffness conforms more to the MDC compared to the DC (previously proposed).

These results will be more advantageous in creating computer simulations and fabric drapability prediction. Though, the fabric samples are small, the results are reasonably acceptable. However, in future, the effect of different textile materials and their manufacturing parameters on the modified drape coefficient is needed to be evaluated before a generalized conclusion can be made.

\section{ACKNOWLEDGEMENT}

This work is supported by National Natural Science Foundation of China (Grant No.61572124).

\section{BIBLIOGRAPHY}

[1] Hu, J., Chan, Y-F., Effect of fabric mechanical properties on drape, In: Textile Research Journal, 1998, 68, 1, pp. 57-64

[2] Frydrych, I., Dziworska, G., Cieślińska, A., Mechanical fabric properties influencing the drape and handle, In: International Journal of Clothing Science and Technology, 2000, 12, 3, pp. 171-183

[3] Robson, D., Long, C. C., Drape analysis using imaging techniques, In: Clothing and Textiles Research Journal, 2000, 18, 1, pp. 1-8

[4] Carrera-Gallissà, E., Capdevila, X., Valldeperas, J., Evaluating drape shape in woven fabrics, In: The Journal of The Textile Institute, 2016, 103, 3, pp. 325-36

[5] Magnenat-Thalmann, N., Volino, P., From early draping to haute couture models: 20 years of research, In: The Visual Computer, 2005, 21, 8-10, pp. 506-519

[6] Chu, C. C., Cummings, C. L., Teixeira, N. A., Mechanics of elastic performance of textile materials Part V: A study of the factors affecting the drape of fabrics - The development of a drape meter, In: Textile Research Journal, 1950, 20, 8, pp. 539-548

[7] Cusick, G., The measurement of fabric drape, In: Journal of the Textile Institute, 1968, vol. 59, no. 6, pp. 253-260

[8] Collier, B. J., Measurement of fabric drape and its relation to fabric mechanical properties and subjective evaluation, In: Clothing and Textiles Research Journal, 1991, 10, 1, pp. 46-52

[9] Behera, B., Pangadiya, A., Drape measurement by digital image processing, In: Textile Asia, 2003, 34, 11, pp. $45-50$

[10] Vangheluwe, L., Kiekens, P., Time dependence of the drape coefficient of fabrics, In: International Journal of Clothing Science and Technology, 1993, 5, 5, pp. 5-8 
[11] Agrawal, S., Study of height dependency of drape parameters, In: International Journal of Engineering Research and Application, 2013, 3, 5

[12] Li, Q. F., Yuan, Y., Relevance analysis between drapability and mechanical properties of the silk fabric, In: International Conference on Control Engineering and Mechanical Design (CEMD 2017): ASME Press, 2018

[13] Jeong, Y., A study of fabric-drape behaviour with image analysis part I: Measurement, characterisation, and instability, In: Journal of the Textile Institute, 1998, 89, 1, pp. 59-69

[14] Carrera Gallissà, E., Juan, C., Javier, F., Valldeperas Morell, J., Abril, H. C., New approach to assessing fabric drape based on the fractal dimension, In: Fibres and textiles in eastern Europe, 2015, 23, 5 (113), pp. 66-70

[15] Payvandy, P., Evaluation of fabric drape coefficient using image processing and fractal dimension, In: The 7th Iranian Conference on Machine Vision and Image Processing, Iran University of Science and Technology, Iran 2011

[16] Park, C. K., Kim, S., Yu, W. R., Quantitative fabric drape evaluation system using image processing technology (Part 1: Measurement system and geometric model), In: Journal of testing and evaluation, 2004, 32, 2, pp. 131-137

[17] Magnenat-Thalmann, N., Volino, P., Bonanni, U., Summers, I. R., Bergamasco, M., Salsedo, F., Wolter, F. E., From physics-based simulation to the touching of textiles: The HAPTEX Project, In: IJVR, 2007, 6, 3, pp. 35-44

[18] Farajikhah, S., Madanipour, K., Saharkhiz, S., Latifi, M., Shadow Moiré aided 3-D reconstruction of fabric drape, In: Fibers and Polymers, 2012, 13, 7, pp. 928-935

[19] Glombikova, V., Kus, Z., Drape evaluation by the $3 D$ drape scanner, In: Journal of Textile \& Apparel/Tekstil ve Konfeksiyon, 2014, 24, 3, pp. 279-285

[20] Jevšnik, S., Geršak, J., Modelling the fused panel for a numerical simulation of drape, In: Fibres \& Textiles in Eastern Europe, 2004, 12, 1, pp. 47-52

[21] Wu, G., Yu, Z., Hussain, A., Zhong, Y., 3D drape reconstruction and parameterization based on smartphone video and Elliptical Fourier Analysis, In: Procedia Computer Science, 2017, 108, pp. 1552-1561

[22] Wu, G., Li, D., Hu, P., Zhong, Y., Pan, N., Automatic foot scanning and measurement based on multiple RGB-depth cameras, In: Textile Research Journal, 2018, 88, 2, pp. 167-181

[23] ASTM D 1388-08, Standard Test Method for Stiffness of Fabrics, 2008

[24] Mizutani, C., Amano, T., Sakaguchi, Y., A new apparatus for the study of fabric drape, In: Textile Research Journal, 2005, 75, pp. 81-87

[25] Cusick, G., The dependence of fabric drape on bending and shear stiffness, In: Journal of the Textile Institute Transactions, 1965, 56, 11, pp. T596-T606

[26] Gulsum, G. P., Musa, K., A new image analysis based device and a new method to determine fabric drape and bending stiffness, In: Industria Textilă, 2015, 66, 3, pp. 146-152

\section{Authors:}

AZMAT HUSSAIN ${ }^{1,3}$, TAYYAB NAVEED ${ }^{1,5}$, DANISH IQBAL ${ }^{4}$, ZHICAI YU ${ }^{1}$, WANG XIN ${ }^{1}$, IQBAL WAQAR 6 , YUEQI ZHONG ${ }^{1,2}$

${ }^{1}$ College of Textiles, Donghua University, Songjiang District, 201620 Shanghai, China

${ }^{2}$ Key Laboratory of Textile Science \& Technology of Ministry of Education, College of Textiles, Donghua University, Songjiang District, 201620 Shanghai, China

${ }^{3}$ Bahauddine Zakariya University, College of Textile Engineering, 54000 Multan, Pakistan

${ }^{4}$ Central Cotton Research Institute, section: Fiber Technology, Multan, Pakistan

${ }^{5}$ Department of Textile Engineering and Technology, University of the Punjab, Lahore

${ }^{6}$ School of Textile, Tianjin Polytechnic University, Tianjin, China

e-mail: azmathussain@bzu.edu.pk; 2195987544@qq.com; idanish424@gmail.com; 1039598561@qq.com; wangxin19930411@163.com; ravianwaqar@hotmail.com

Corresponding authors:

YUEQI ZHONG

e-mail: zhyq@dhu.edu.cn 


\title{
Theoretical model: analysing theoretically the air flow through car seat foam material
}

\author{
DOI: $10.35530 / 1 T \cdot 070.04 .1559 B$
}

\section{REZUMAT - ABSTRACT}

Model teoretic: analiza fluxului de aer prin materialul poros al scaunului auto

Confortul scaunelor auto reprezintă o caracteristică foarte importantă pentru autoturisme. Permeabilitatea la aer este direct legată de respirabilitatea și de confortul scaunelor auto. În acest studiu, spuma poliuretanică (PU) cu diverse orificii a scaunelor auto a fost testată din punctul de vedere al permeabilitătii la aer și simulată numeric pentru analiza fluxului de aer. Modelul geometriei detaliate oferă o imagine asupra fluxului de aer (presiune și viteză) prin volumul spumei, influențat de perforații și caneluri. Dar fenomenul simulat este diferit de cel măsurat. Fluxul de aer se formează in principal prin perforații (99\%), iar prin spumă este cu două unități mai scăzut. Folosind geometria omogenă cu permeabilitate "medie", parametrii au fost evaluați pe baza valorilor măsurate. Similitudinea fenomenului măsurat și simulat este foarte bună, cu o diferență de 1-5\%. Însă nu a fost posibil să se obțină detalii despre fluxul de aer în volumul de spumă.

Cuvinte-cheie: permeabilitate la aer, simulare numerică a fluxului de aer, material poros de grosime ridicată

\section{Theoretical model: analysing theoretically the air flow through car seat foam material}

Comfort of car seats is very important property for cars. Air permeability is directly related to the breath ability and comfort of car seats. In this research car seat Poly Urethane (PU) foam with different holes are tested for the air permeability and numerically simulated to predict the flow of air through thick foams. Model of detailed geometry gives good view about detailed flow field (pressure and velocity) in foam volume, influenced by perforations and grooves. But simulated flow is several times different from measured one. The main flow is through perforations (99\%) and flow through foam is of two orders lower. Using homogeneous geometry with "averaged" permeability parameters were evaluated from measured values. The coincidence of measured and simulated flow is very good, difference of $1-5 \%$. But it is not possible to get any details of flow in foam volume.

Keywords: air permeability, flow numerical simulation, thick foams

\section{INTRODUCTION}

Every middle-size vehicle uses between 12 and $14 \mathrm{~kg}$ of textile products, without including tire cords for pneumatic and fibres which are used in composite materials. The $65 \%$ of this quantity is used approximately in the interior (40 to $45 \mathrm{~m}^{2}$ of textile material per car) with a weight between 350 and $450 \mathrm{~g} / \mathrm{m}^{2}$ for the seats upholstery [1-4].

Textile advances in the automotive industry have been spearheaded by advances in science and technology of fibres and fabric/web forming technologies. These advances have led to the development of textiles and textile-based components for a broad variety of automotive applications which are capable of meeting the industry's tough specifications regarding high performance during use [5-10].

Development of car seat components. Parts, pieces and materials are orientated by the following criteria:

- Comfort

- Functionality

- Safety

- Economy

- Ecology
Car seat is perhaps, the most important part of the interior, it is the first element that the customer appreciates when he/she opens the door to look inside and it is the main interface between person and machine. The comfort is directly related to the air permeability of the car seat layers, if its possible to predict the air permeability of different layers then it's possible to evaluate the thermos physiological comfort of car seats.

\section{EXPERIMENTAL PART}

In this research work, classical PU foam of $30 \mathrm{~mm}$ and $5 \mathrm{~mm}$ thickness is used. The foams have area of $165 \mathrm{~cm}^{2}$. Figure 1 description of real sample of PU-foam with holes

\section{Air permeability of samples}

Concerning the terminology "permeability", used in textile technologies is defined as volume flow $\left(\mathrm{m}^{3} / \mathrm{s}\right)$ through the sample area $\left(\mathrm{m}^{2}\right)$, (i.e. $\left(\mathrm{m} / \mathrm{s}=\mathrm{m}^{3} / \mathrm{s} \cdot \mathrm{m}^{2}\right)$. In the fluid mechanics the same parameter is known as "volume flow density". 


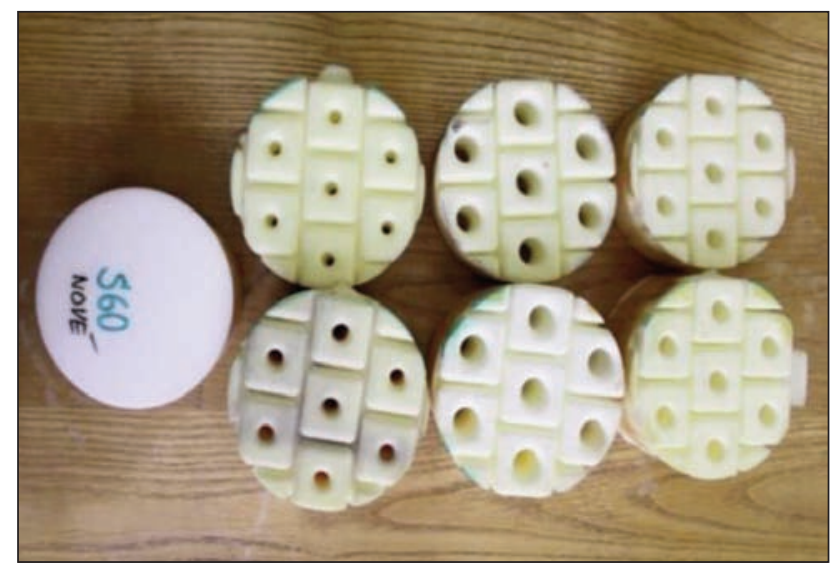

Fig. 1. Real samples of foams

It should be better to use the "mass flow density $\left(\mathrm{kg} / \mathrm{s} \cdot \mathrm{m}^{2}\right)$ ", which is independent on state quantities (pressure. temperature). This term is used in simulations below and in the fluid mechanics, too. Therefore for later comparison of measured and simulated flows the measured volume flows $(\mathrm{ml} / \mathrm{s})$ are recalculated into mass flows $(\mathrm{kg} / \mathrm{s})$.

Air permeability describes the rate of flow of a fluid through a porous material, and the mathematical expression is given by:

$$
q=\frac{Q}{A t}
$$

Where $q$ is rate of flow $(\mathrm{m} / \mathrm{s}), Q$ - volume of flow of fluid through the sample $\left(\mathrm{m}^{3}\right), t-$ time $(\mathrm{s})$ and $A-$ the cross-sectional area $\left(\mathrm{m}^{2}\right)$.

Textile material stands out as a unique class of porous media, which contain relatively high volume of air and very complex structure due to the random arrangement of fibres or pores. Air permeability is one of the most important properties of textile materials in many applications, Numerous researchers
Where $q$ is the rate of flow $(\mathrm{m} / \mathrm{s}), K_{p}$ - the flow permeability coefficient $\left(\mathrm{m}^{2}\right), \Delta p$ - the pressure gradient (pa), $\mu$ - the viscosity of the flow (pa.s), $L-$ the thickness of sample $(\mathrm{m}), \mathrm{Q}$ - the volume flowing in time $\left(\mathrm{m}^{3}\right), A$ - the cross-section area $\left(\mathrm{m}^{2}\right)$ where flow goes through, $t$ - time (s).

As explained in the Literature review part that the air flow and the water vapor permeability are the connected properties. This gives us the idea to theoretically analyses the flow of air through the textile layers and predict the performance of the car seat materials. For this research the software FLUENT is used for the theoretical analyses and the results are compared with the experimental results.

The permeability is defined as the volume flow $V$ $\left(\mathrm{m}^{3} / \mathrm{s}\right)$ through the cross-section of the sample $S\left(\mathrm{~m}^{2}\right)$. So the permeability is identical with flow velocity through tested sample:

$$
w=\frac{V}{S}(\mathrm{~m} / \mathrm{s})
$$

\section{APPLICATION OF MEASURED DATA}

\section{Used samples}

Thick PU cushion part of the car seat is used for this research. The classical foam and the foam with the perforation are used for this research the properties are shown in table 1 below.

The hole dimensions of used samples are shown in figure 2 .

\section{Measured air permeability}

The air permeability of the samples are tested under different pressure difference by standard method ISO standard 9237. Results are shown below. It is quite obvious that the PU-foam without holes is almost impermeable and the flow increases with the size of hole.

\begin{tabular}{|c|c|c|c|c|c|c|}
\hline \multicolumn{7}{|c|}{ PU-FOAM PROPERTIES FOR THE NUMERICAL SIMULATION } \\
\hline Samples & $\begin{array}{c}\text { Foam } \\
\text { thickness } \\
(\mathbf{m m})\end{array}$ & $\begin{array}{c}\text { Number } \\
\text { of holes }\end{array}$ & $\begin{array}{c}\text { Hole } \\
\text { diameter } \\
(\mathbf{m m})\end{array}$ & $\begin{array}{c}\text { Total area of } \\
\text { foam sample } \\
\left(\mathbf{m m}^{2}\right)\end{array}$ & $\begin{array}{c}\text { Area } \\
\text { of holes } \\
\left(\mathbf{m m}^{2}\right)\end{array}$ & $\begin{array}{c}\text { Area of solid } \\
\text { foam } \\
\left(\mathbf{m m}^{2}\right)\end{array}$ \\
\hline A & 60 & 0 & 0 & 16505 & 0 & 16505 \\
\hline A1 & 60 & 7 & 10 & 16505 & 550 & 15955 \\
\hline A2 & 60 & 7 & 15 & 16505 & 1236 & 15268 \\
\hline A3 & 60 & 7 & 20 & 16505 & 2198 & 14307 \\
\hline
\end{tabular}

have worked on the air permeability of non-woven fabrics in both experiment [2-4] and analytical prediction [5-7]. Darcy derived an equation for calculating the air permeability based on hydraulic radius theory, which states that rate of flow is directly proportional to the pressure gradient causing the flow. The equation is as follows:

$$
Q=\frac{A \cdot t\left(K_{p} \cdot \Delta P\right)}{\mu L}
$$

AIR PERMEABILITY VALUES AT DIFFERENT PRESSURE

\begin{tabular}{|c|c|c|c|c|}
\hline \multirow{2}{*}{$\begin{array}{c}\text { Press } \\
(\mathbf{P a})\end{array}$} & \multicolumn{4}{|c|}{ Unit (mL/sec) } \\
\cline { 2 - 5 } & $\mathrm{F} 0$ & $\mathrm{~F} 1$ & $\mathrm{~F} 2$ & $\mathrm{~F} 3$ \\
\hline 1.1 & 0.2 & 19 & 43 & 60 \\
\hline 1.5 & 0.6 & 45 & 92 & 140 \\
\hline 2 & 1.1 & 70 & 125 & 200 \\
\hline 2.2 & 1.25 & 80 & 145 & 235 \\
\hline
\end{tabular}




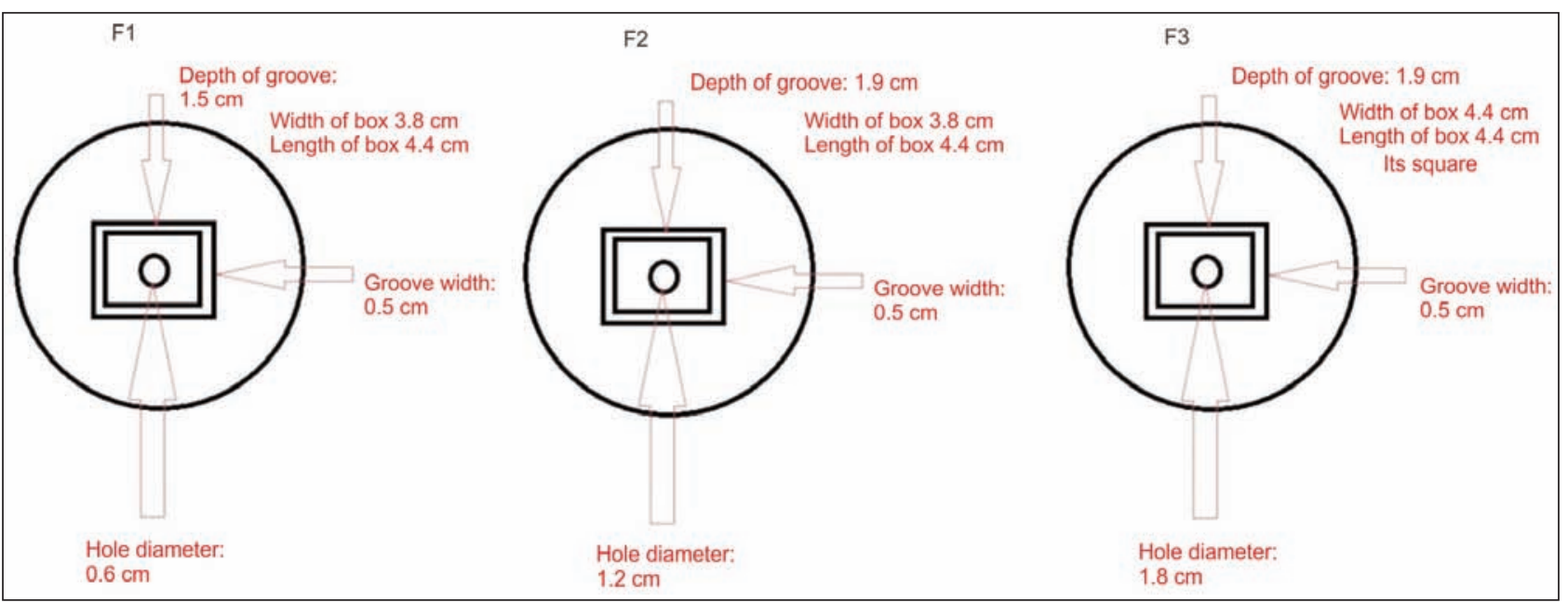

Fig. 2. Description of real sample of PU-foam with holes

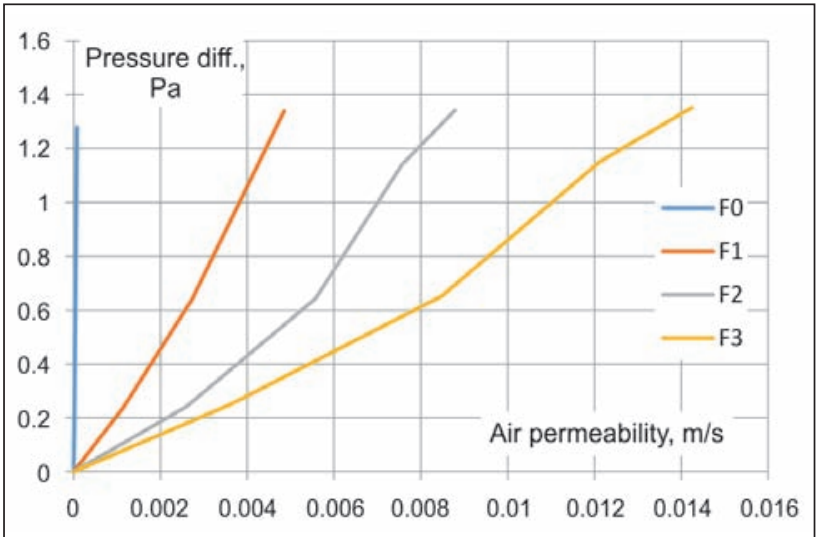

Fig. 3. Air permeability at different pressure

Permeability of the classical foam (F0) is 64-188 times lower permeable than cases F1-F3 as shown in figure 3.

\section{Adaptation of measured data}

Following evaluation of measured data and determination of permeability parameters is explained for the case F0 (full foam) only. Next cases (F1-F3) are created as foam bodies (F0) with additional perforations and grooves.

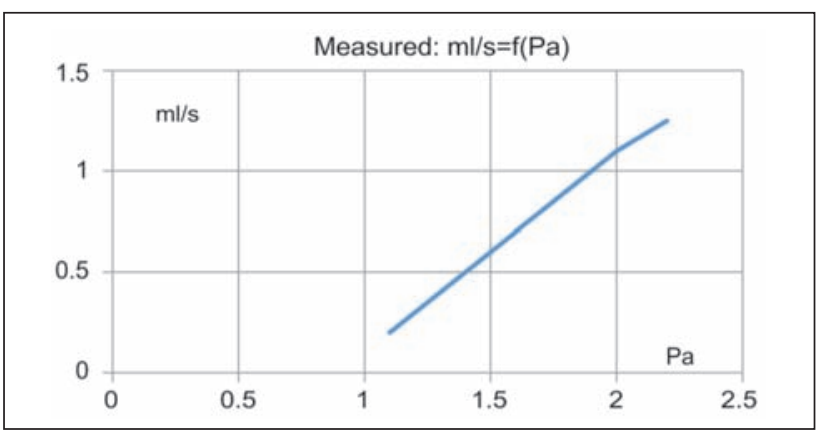

Fig. 4. Measured values of volume flow

The flow starts at $1 \mathrm{~Pa}$ approx. - from the physical point of view it is not precise - and might be influenced

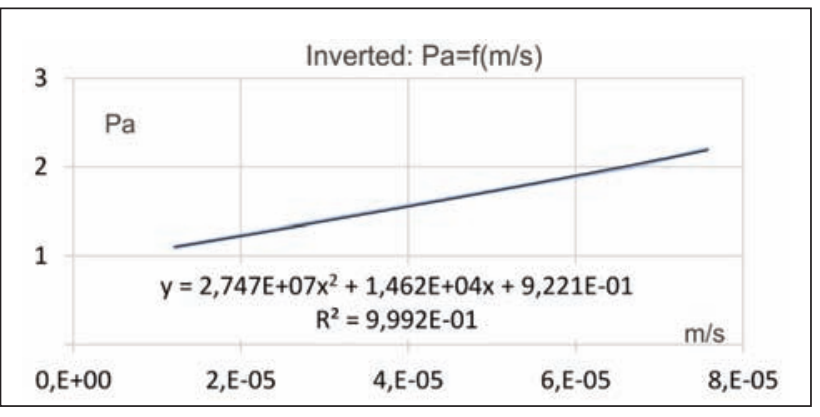

Fig. 5. Recalculation in permeability

by the insensitivity of measuring device under $1 \mathrm{~Pa}$ pressure.

Measured volume flows $(\mathrm{ml} / \mathrm{s})$ are recalculated in permeability $\mathrm{m} / \mathrm{s}\left(=\mathrm{m}^{3} / \mathrm{s} \cdot \mathrm{m}^{2}\right)$ and inverted.

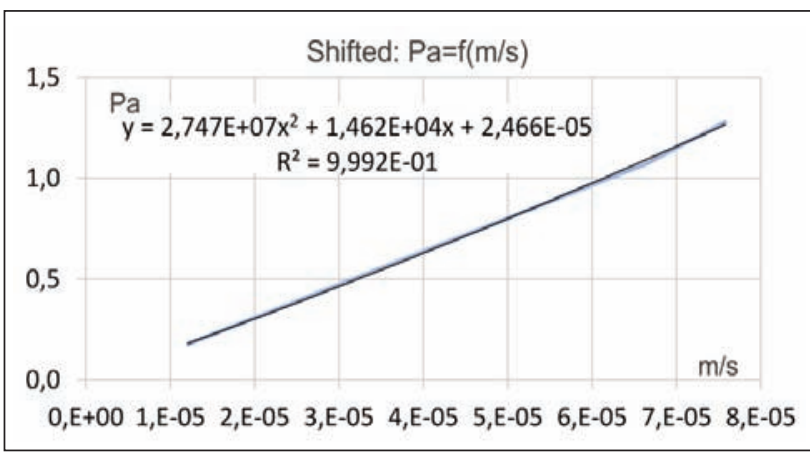

Fig. 6. Shifted values

Values are shifted, to correct any measuring error (at zero mass flow the flow resistance must be zero, too). After such correction the permeability parameters can be determined.

\section{Permeability parameters determination}

The method is described in [10] for so-called "pressure jump" in one-dimensional flow and thin porous layer. Here is the method used for so-called "porous zone", generally as the flow in 3-dimensional permeable volume (thick porous layer). Theoretical formulas 
[10] are analogous, so it is supposed to use the same procedure in 3D for homogenous permeability. Generally, the qualitative results (images of flow fields), are all right, but the quantitative results of simulations ( $\mathrm{m} / \mathrm{s}, \mathrm{kg} / \mathrm{s}$ etc.) are different from measured values.

The permeability of the observed layer is given by its flow resistance. This resistance consists in general from the linear term, typical for instance for small velocities (so-called Darcy's law) and from the quadratic term, typical for flow around bodies or through channels (Weissbach's or Moody's law):

$$
\Delta p=C_{2} \cdot \frac{\rho}{2} \cdot t \cdot w^{2}+\frac{\mu}{\alpha \cdot t \cdot w}
$$

where:

$w=V / S(\mathrm{~m} / \mathrm{s})$ is flow velocity;

$V\left(\mathrm{~m}^{3} / \mathrm{s}\right) \quad-$ volume flow;

$S\left(\mathrm{~m}^{2}\right) \quad-$ flow cross-section (here $20 \mathrm{~cm}^{2}$ );

$t(\mathrm{~m}) \quad-$ layer thickness;

$\rho\left(\mathrm{kg} / \mathrm{m}^{3}\right)$ - medium density (for atmospheric air $\left.1,2 \mathrm{~kg} / \mathrm{m}^{3}\right)$;

$\mu\left(\mathrm{m}^{2} / \mathrm{s}\right) \quad-$ viscosity (for air $\left.1,806 \mathrm{e}-5\right)$;

$\alpha\left(m^{2}\right), C_{2}(1 / m)-$ unknown permeability parameters [10].

Two unknown permeability parameters $\alpha, C_{2}$, depending on the layer structure, can be determined from the experimental data.

In previous graphs the function $\mathrm{Pa}=f(\mathrm{~m} / \mathrm{s})$ is substituted by quadratic function with very high correlation coefficient. Parameters of this substitution are used as follows:

Comparing the formula for pressure resistance as function of velocity:

$$
\Delta p=A \cdot w^{2}+B \cdot w+C
$$

From Eq. 5 we can determine two unknown permeability parameters $C_{2}$, $\alpha$ from:

$$
\begin{aligned}
& A=C_{2} \cdot \frac{\rho}{2} \cdot t \\
& B=\frac{\mu}{\alpha t}
\end{aligned}
$$

where $A, B$ (and $C$, which should be equal zero) are parameters of the quadratic substitution.

For given values of

$$
\begin{array}{ll}
\text { thickness } & t=0,03 \mathrm{~m}, \\
\text { air density } & \rho=1,2 \mathrm{~kg} / \mathrm{m}^{3}, \\
\text { dynamic viscosity } & \mu=1,806 \mathrm{e}-5 \text { (Pa.s) }
\end{array}
$$

the permeability parameters are as follows:

$$
\begin{aligned}
& C_{2}=\frac{2 \cdot A}{\rho \cdot t} \\
& \alpha=\frac{\mu \cdot t}{B}
\end{aligned}
$$

Determined permeability parameters for F0 are

$$
C_{2}=1,526 \mathrm{e}+09(1 / \mathrm{m}), \quad 1 / \alpha=2,698 \mathrm{e}+10\left(1 / \mathrm{m}^{2}\right)
$$

For testing purposes the foam F0 is used, only, foams F1, F2, F3 are not evaluated here, because the relevant models are created as foam body (permeability parameters of F0) with perforations and grooves.

\section{NUMERICAL SIMULATIONS}

The basic model of the numerical simulation was designed and the software was run with the input equation and the parameters form the experimental results. The basic model is shown in figure 7 .

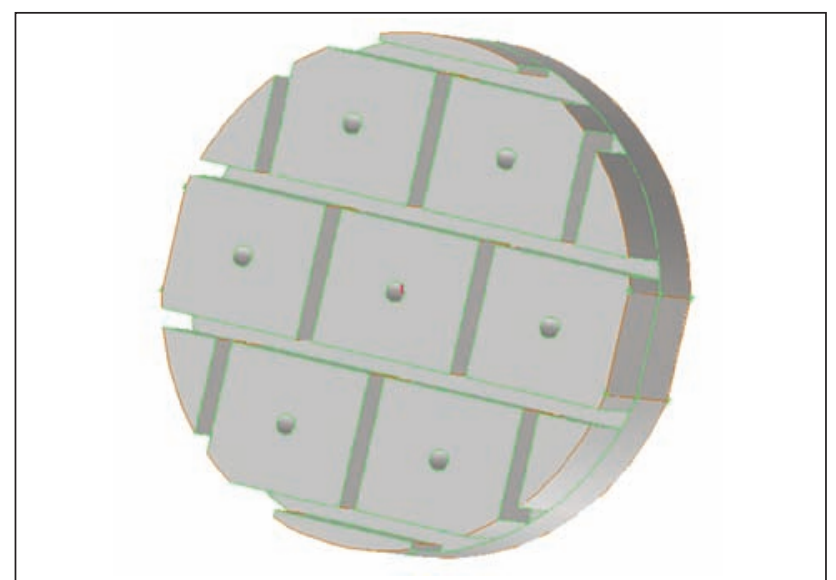

Fig. 7. Basic model of numerical simulation

The main results of the numerical simulation are shown in the table 3. Differences between flows of inlet and outlet are not important. Even if the holes area is $1,1 \%$ of the total area of sample, the main flow is going through holes and the flow through the foam material is less than $1 \%$ approximately. It could be stated that the foam is practically impermeable and used as compressible cushion.

Table 3

INLET AND OUTLET PREDICTION OF LOW

\begin{tabular}{|c|l|c|c|c|c|c|}
\hline \multirow{2}{*}{ Samples } & \multicolumn{2}{c|}{ Area } & \multicolumn{2}{c|}{ Mass flow } & Measured \\
\cline { 3 - 7 } & & $\left(\mathbf{m}^{2}\right)$ & $(\%)$ & $\mathbf{( k g / s )}$ & $\mathbf{( \% )}$ & $\mathbf{( k g / s )}$ \\
\hline \multirow{4}{*}{ inlet } & foam & 0.012858 & 78.2 & $0.92794 \mathrm{e}-6$ & 0.3 & \\
\cline { 2 - 7 } & grooves & 0.003415 & 20.8 & $2.24480 \mathrm{e}-6$ & 0.8 & \\
\cline { 2 - 7 } & holes & 0.000178 & 1.1 & $2.80000 \mathrm{e}-4$ & 98.8 & \\
\cline { 2 - 7 } & sum & 0.016452 & & $2.83300 \mathrm{e}-4$ & & $0.415 \mathrm{e}-4$ \\
\hline \multirow{4}{*}{ outlet } & foam & 0.016273 & 98.9 & $2.07184 \mathrm{e}-6$ & 0.7 & \\
\cline { 2 - 7 } & holes & 0.000178 & 1.1 & $2.81000 \mathrm{e}-4$ & 99.2 & \\
\cline { 2 - 7 } & sum & 0.016451 & & $2.83300 \mathrm{e}-4$ & & $0.415 \mathrm{e}-4$ \\
\hline
\end{tabular}

Next serial of flow fields presents main qualitative results. To get full details of individual flow fields different scales are used. The model is shown with different graphical representation.

Pressure is penetrating into blind/closed grooves, stopped at the groove bottom. In continuous holes the value is low due to conversion of the pressure into velocity.

The main flow is through holes, the flow through foam is extremely low. 


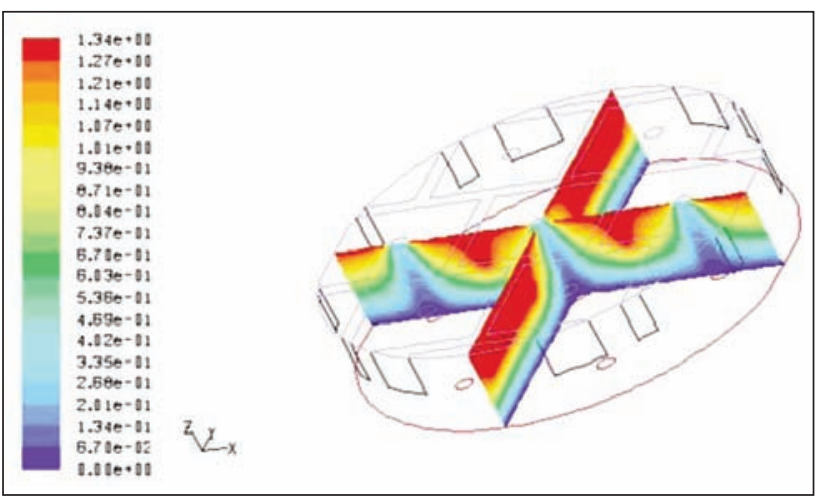

Fig. 8. Pressure field - axial cross sections

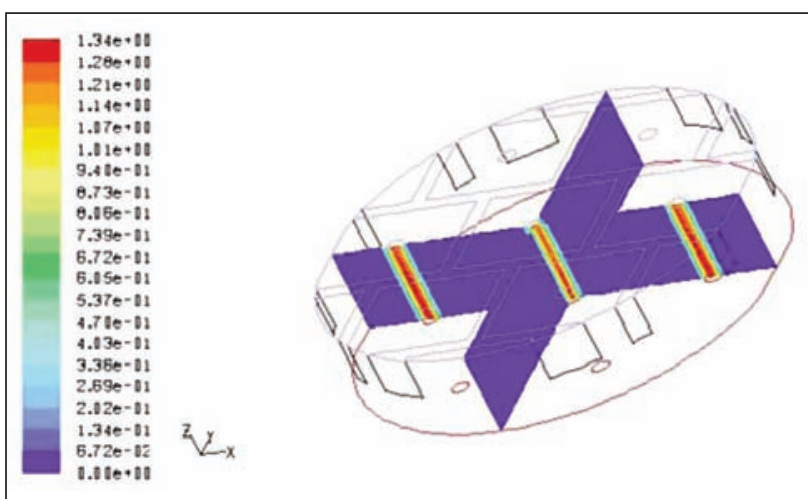

Fig. 9. Velocity field - axial cross sections - full scale

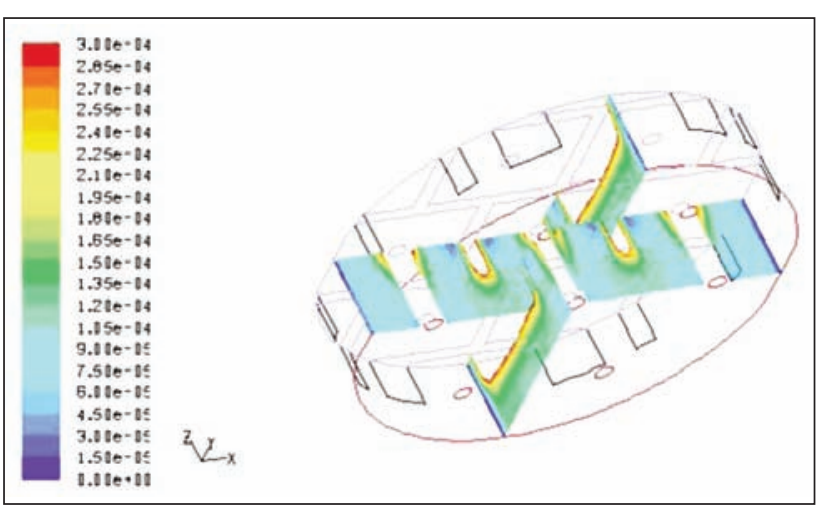

Fig. 10. Axial cross sections. suppressed scale

Flow in grooves is stopped at the groove bottom and slightly is penetrating into foam volume. Simulation can explain details of flow in permeable volume.

The velocity field at the inlet plane is maximum in the holes.

Local maximum in larger cross sections (in T-junctions). Individual irregularities could be suppressed by finer mesh.

Figures 8-13 show flow fields from main qualitative results. To get full details of individual flow fields different scales are used. The model is shown with different graphical representation.

\section{Foam under load (pressed)}

Hypothesis for this part of the model is that if the foam is pressed then the foam volume by $50 \%$ in the

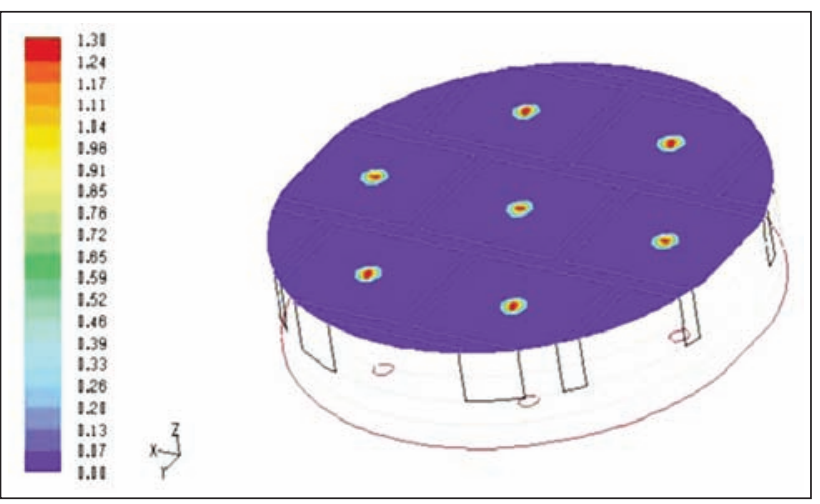

Fig. 11. Velocity field at the inlet plane - full scale. Maximum in holes

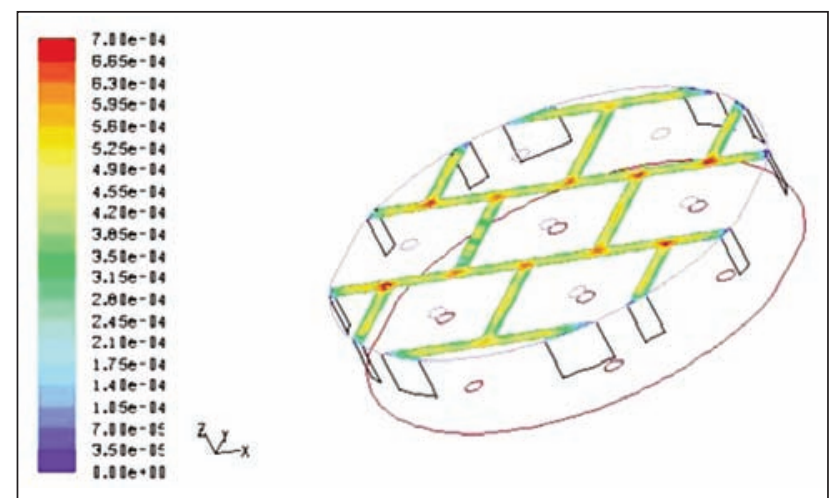

Fig. 12. Velocity field in grooves at the inlet side - suppressed scale

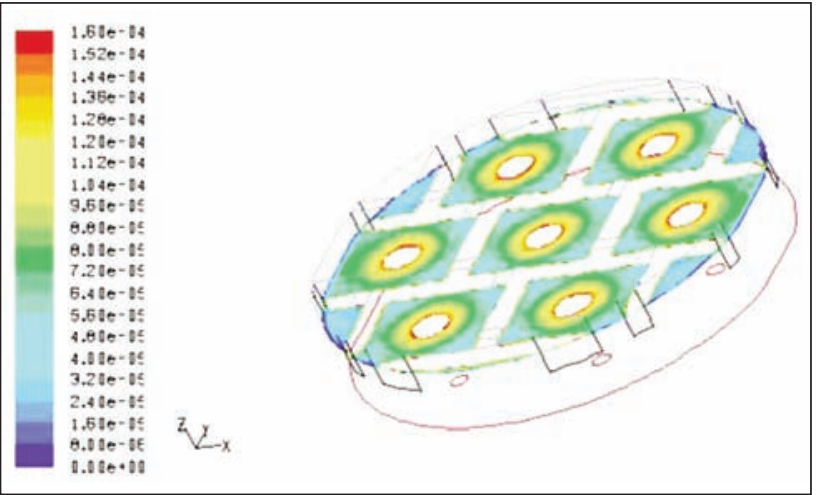

Fig. 13. Velocity field $7.5 \mathrm{~mm}$ from the inlet side - suppressed scale

flow direction. The inner permeable cells are also pressed by $50 \%$ too, so eventually the permeability is also decreasing by $50 \%$ too. And more, it is supposed that geometry deformation is along the axis of deformation and there is no abnormal shape or buckling in cross directions.

For simple verification the model geometry remains the same. New parameters of permeability are determined as in the table 4 from the condition of $50 \%$ of measured flow.

Results are summarized in the tabel 5 where original mass flows mass flows through foam and grooves is decreased by $28 \%$ and $27 \%$ respectively of original values. It means from $1 \%$ of the whole flow to $0.3 \%$ 


\begin{tabular}{|c|c|c|c|}
\hline & & & Table \\
\hline \multicolumn{4}{|c|}{$\begin{array}{l}\text { PERMEABILITY PARAMETERS FOR 50\% FLOW } \\
\text { (DUE TO FOAM PRESSING) }\end{array}$} \\
\hline & $\mathrm{C} 2$ & $\alpha\left(m^{2}\right)$ & $1 / \alpha\left(1 / \mathrm{m}^{2}\right)$ \\
\hline Fo & $1.111 \mathrm{E}+10$ & 7.052E-12 & $1.418 \mathrm{E}+11$ \\
\hline
\end{tabular}

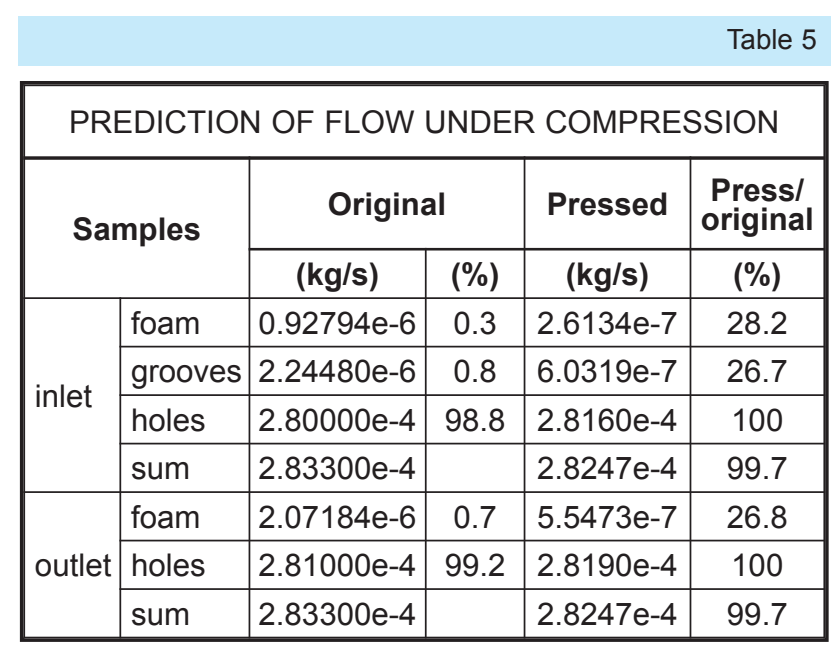

approximately. It has not any influence on the flow through holes, as it represents $99 \%$ of the whole flow and some small flow changes in foam and grooves does not have any influence.

\section{Testing cases of full foams}

Two cases of full foams (F0, F1) were solved; differences between simulated and measured mass flows are $1 \%-5 \%$, only. The detailed geometry gives good imagination about fine details of velocity and pressure field in the foam volume, the main flow is going through perforations.

On the other side, the simple model of "foam" presents the average flow, regardless of perforations and grooves. Therefore the correlation of measured and simulated mass flow is very good, but details of flow field inside the foam volume cannot be perceived.

Figure 14 shows differences between mass flows in $\mathrm{F} 0$ and $\mathrm{F} 1$.

\section{CONCLUSION}

The results from many solved cases of numerical flow simulation in the PU-foam with the perforation can be summarized as below

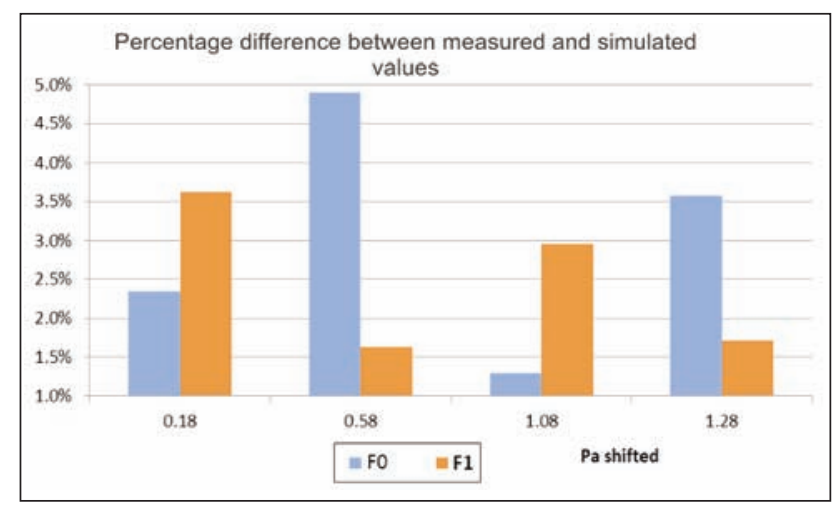

Fig. 14. Difference between measured and simulated mass flows for foams F0 and F1

1. It is possible to state that the method of numerical flow simulation used for the air permeability through porous medium gives a good imagination about the main features of the flow field in complicated structures, considering both continuous and blind air volumes and foam volumes (for instance the pressure or velocity distribution. concentration of the flow in the foam area around individual holes and grooves, flow spreading from the groove bottom in foam. flows in foam. induced by strong flow in adjoining holes etc.).

2. Using the simple geometry of full foam (case F0). The difference between mass flows measured and simulated is very low (few percentage only). In case of F0 there is not much flow of air. Therefore it could be stated that strong flows through perforated holes have the main effect in total mass flow balance and the flow through foam is negligible.

3. Influence of pressed foam layer has practically no influence on the total flow. According to previous points. The main part is flowing through "empty" holes practically without resistance (compared with reduced flow through the foam volume. due to the higher foam resistance after pressing).

The simulation can be used to test it with even more added layers and check the permeability of sandwich car seat covers.

\section{ACKNOWLEDGEMENT}

This work was supported by the Ministry of Education, Youth and Sports of the Czech Republic and the European Union - European Structural and Investment funds in the frames of operational program Research, Development and Education - Project Hybrid Materials for Hierarchical Structures (HyHi, Reg. No. CZ.02.1.01/0.0/16_019/0000843).

\section{BIBLIOGRAPHY}

[1] Jerkovic, I., Pallares, J.M., Capdevila, X., Study of the abrasion resistance in the upholstery of automobile seats, In: AUTEX Research Journal, 2010, 10, pp. 14-20

[2] Ford's Sustainable Materials Strategy, Feb. 2012, Excess date: 30.03.2017 http://media.ford.com/images/10031/ Ford_Sustainable_Materials_Fact_Sheet.pdf

[3] Environmental \& Social Report, 2005, Excess date 30.03.2017 http://www.toyotaglobal.com/sustainability/report/ sr/05/pdf/eco_04.pdf 
[4] Söderbaum, E., Requirements for automotive textiles - a car producer's view in Textile advances in the automotive industry, In: Woodhead Publishing in Textiles, 2008, 79, pp. 3-15, ISBN: 978-1-84569-331-2

[5] Havelka, A., Glombiková, V., Mazari, F.B., Monitoring thermophysiological comfort in the interlayer betweendriver and the carseat. In: Vlakna a Textil, 2015, (3/4), pp. 40-45, ISSN 13350617 (Scopus)

[6] Slater, K., Human Comfort, In: Thomas Publisher, Springfield, IL, USA, 1985, 4, ISBN:0398051283

[7] Choudhary, A.K.R., Majumdar, P.K., Datta, C., Factors affecting comfort: Human physiology and role of clothing, Improving Comfort in Clothing, In: Wood Head Publishing, 2011, pp. 1-57, ISBN: 1845695399

[8] Tugrul Ogulata, R., The effect of thermal insulation of clothing on human thermal comfort, In: Fibres \& Textiles in Eastern Europe, 2007, 61(2), pp. 67-72

[9] Das, A., Alagirusamy, R., Science in clothing comfort, In: Wood Head Publishing, UK, 2011, ISBN 1845697898

[10] Sharma, S., Topical drug delivery systems: A review. Available, from: http://www.pharmainfo.net. 2016

\section{Authors:}

MAZARI FUNDA BUYUK ${ }^{1}$, MAZARI ADNAN ${ }^{1}$, HAVELKA ANTONIN¹, ADAMEK KAREL ${ }^{2}$

${ }^{1}$ Technical University of Liberec, Faculty of Textile Engineering, Department of Textile Clothing,

Studentska 2, Liberec, 461 17, Czech Republic

${ }^{2}$ VúTS Liberec, Svárovská 619, CZ-46119 Liberec

Corresponding author:

MAZARI FUNDA BUYUK

e-mail: fundabuyuk@hotmail.com 


\title{
Basic modeling of the visco elastic behavior of flax fiber composites
}

\author{
DOI: 10.35530/IT.070.04.1512
}

CONSTANTIN STOCHIOIU

STEPHANE FONTAINE

BENOIT PIEZEL

AMEUR CHETTAH

\section{REZUMAT - ABSTRACT}

Modelarea comportamentului viscoelastic al compozitelor din fibră de in

La mijlocul secolului al XX-lea, compozitele armate cu fibre de carbon și de sticlă au devenit populare, fiind pe primul loc în cadrul acestei industrii în curs de dezvoltare. Totuși, acestea au anumite dezavantaje care au condus spre dezvoltarea de materiale noi. Cererile actuale se îndreaptă către materiale ieftine și regenerabile. S-a dovedit că fibrele de in deţin cele mai bune proprietăți mecanice dintre fibrele naturale utilizate ca bio-armături, apropiate de cele ale fibrelor de sticlă. Aceste avantaje, împreună cu o densitate mai scăzută decât cea a sticlei și posibilitatea de reciclare, au făcut ca armarea cu fibre de in să fie un candidat pentru următoarea generație de compozite. Împreună cu aceste puncte forte, vine un comportament care, pentru compozitele menționate mai sus, poate fi adesea neglijat: comportamentul dependent de timp. Obiectivul acestei lucrări este să studieze această proprietate și să propună un model pentru evoluția ei. Compozitul analizat este o rășină epoxidică armată cu fibre lungi de in, orientate la $\pm 45^{\circ}$, pentru a pune în evidenţă comportamentul la forfecare al materialului. Procedura experimentală constă dintr-un test de rezistență la tracțiune pentru a determina proprietățile mecanice ale compozitului, în această direcție și pentru a stabili nivelurile de tensiune pentru testele dependente de timp. În al doilea rând, au fost efectuate teste de fluaj-revenire în patru niveluri, cu un fluaj de o oră și o recuperare de cinci ore. În ultima parte a lucrării este prezentată modelarea liniară a acestui fenomen, bazată pe modelele Zener și Burger.

Cuvinte-cheie: biocompozite, viscoelasticitate, model Zener, model Burger

\section{Basic modeling of the visco elastic behavior of flax fiber composites}

In the middle of the $20^{\text {th }}$ century, fiber reinforced composites became mainstream, with carbon and glass fibers at the forefront of this developing industry. However, they have certain disadvantages which have driven the research towards the discovery of novel materials. Today's demands go towards cheap and renewable materials. It has been proven that flax fiber possesses some of the best mechanical properties of bio-reinforcements, close to the ones of the glass fibers. These advantages, together with a lower density than glass and the possibility of recycling have made the flax fiber reinforcement a candidate for the next generation of composites. Along with these strong points, comes a behavior, which, for the composites mentioned earlier, can often be neglected: the time dependent behavior. The present work aims at studying this property and to propose a basic model for its evolution. The analyzed composite is an epoxy resin reinforced by long flax fibers, oriented at $\pm 45^{\circ}$, which show the shear behavior of the material. The experimental procedure consists of a tensile test to determine the mechanical properties of the composite on this direction and to establish the stress levels for the time dependent tests. Secondly, four levels of creep recovery tests are conducted with a creep of one hour and recovery of five hours. In the last part of the paper, linear modeling of this phenomenon is presented, based on the Zener and Burger models.

Keywords: bio-composites, viscoelasticity, Zener model, Burger model

\section{INTRODUCTION}

Fiber reinforced plastics (FRPs) have been a revolution in the design of structures. The fact that their mechanical properties can be tailored to specific applications is a great advantage over metals and, along with their lower density [1], have led this class of materials to be the preferred choice in certain fields of the industry, such as aerospace, automotive or sports goods [2], where weight is an important factor.

Although they come with a vast variation of properties [3], due to the constituents and the interaction between them, FRPs have been shown to possess one in common: a time varying rigidity [4]. Normally, it is a disadvantage that the material changes its properties in time but, it can be an advantage if one, for example, wishes to use such a material in vibration damping applications [5]. The responsible for this behavior is the plastic matrix and, depending on the reinforcing fiber and its percentage in the composite, it can be significant when long term shape stability is considered. Myiano et al. have shown, by constructing a creep master curve, that an epoxy resin, at $50^{\circ} \mathrm{C}$ can reduce to less than a half its rigidity, over a period of approximately 69 days [6]. Another epoxy resin has been tested by Hiel et al. has shown a similar decrease in rigidity at room temperature [7]. Luo et al. have conducted creep tests on a PMMA resin which have shown, at room temperature, a loss of 
approximately $67 \%$ in rigidity, over a period of 4000 seconds [8].

It is obvious that, for the plastic matrix alone, loads sustained for an extended period of time produce significant change in terms of mechanical properties. In the case of fiber reinforced plastics, on the other hand, the mechanical properties of the matrix play a less significant role. Its function, in the composite, is for fiber protection and stress distribution throughout the material [9]. Thus, the deformations obtained during a creep period are lower in comparison. For example, Tuttle and Brinson have recorded, for a carbon fiber reinforced epoxy resin, an increase in deformation of approximately $10 \%$, after maintaining a constant load for 480 min [10]. Similarly, Mohan et al. have conducted experiments on an epoxy resin glass fiber system [11]. The creep curves that they present show an increase of less than $10 \%$ in one hour of testing, at room temperature.

The examples presented are what can be called a classical composite material, which have been the subject of many studies and have been used in many applications. In the recent years, however, green composites have been a significant subject of research [12-15], with the flax fibers being the most suited for structural applications, in terms of ultimate strength [16-17]. They, however present a more significant visco elastic effect when subjected to high loads [18-19], making it significant when designing structures using flax fiber reinforced composites. From here arises the need to understand and model this behavior.

The current work is focused on simple rheological modeling, with the intention of regarding how well it could be implemented for the design of structures. For the parameter identification, the least squares method has been used with success in other similar works as is the one presented by Houanou [20]. It was adopted and introduced in a MatLab script, as it produces rapid and reliable results and, based on it, an error analysis can be conducted.

\section{MATERIALS AND EQUIPMENT}

For the viscoelastic testing, two samples with the fiber direction of $\pm 45^{\circ}$ were used. They were fabri- cated out of the flax fiber prepreg known commercially as Lineo Flaxpreg T-UD20, through a cycle of thermo-compression at $130^{\circ} \mathrm{C}$ and a pressure of 3 bars applied from $115^{\circ} \mathrm{C}$, followed by a post curing cycle without pressure at the same temperature for a period of two hours.

The first sample was used for a traction test. It was painted on one side with a white coat, followed by random black dots, used for the reading of the deformation (figure 1,a). The recording was made with an INSTRON GOM stereo correlation camera. The other sample was equipped with four strain gages, two mounted on the longitudinal direction and two on the transverse one (figure 1,b). The two pairs were mounted back to back in order to eliminate the possible effect of flexion of the specimen during the creep test. The tensile test was realized with a MTS Criterion C45 tensile testing machine, equipped with a $10 \mathrm{kN}$ load cell and the creep tests with a SHIMADZU AGS-X series equipped with a $5 \mathrm{kN}$ load cell.

During the two types of tests, acoustic emission was recorded from the samples with an AEM Micro 80 acoustic emission system, with two microphones mounted at the extremities of the sample, $100 \mathrm{~mm}$ apart.

\section{EXPERIMENTAL PROCEDURE}

The purpose of the tensile test was to determine the mechanical properties and the shear stress - shear strain curve of the material. This was used to choose the parameters of the creep tests, such as the stress levels. The intention was to determine if it is possible to go up as high as $20 \mathrm{MPa}$ of shear stress, while still in the linear portion of the curve and that the creep experiments would be under the limit of internal damage. It is desirable for this to be the case as the damage of the sample would introduce parasitic deformations which would introduce errors in the model. The stress strain curve can be seen in figure 2 .

It is visible that the material has a linear behavior until approximately $25 \mathrm{MPa}$, thus suggesting the upper limit for the creep tests. The acoustic emission provides the information on the damage which starts at 27,63 MPa. This value is higher than the desired

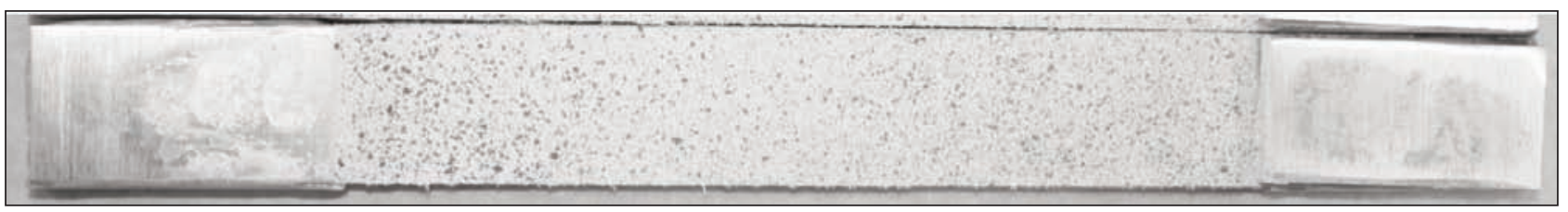

a

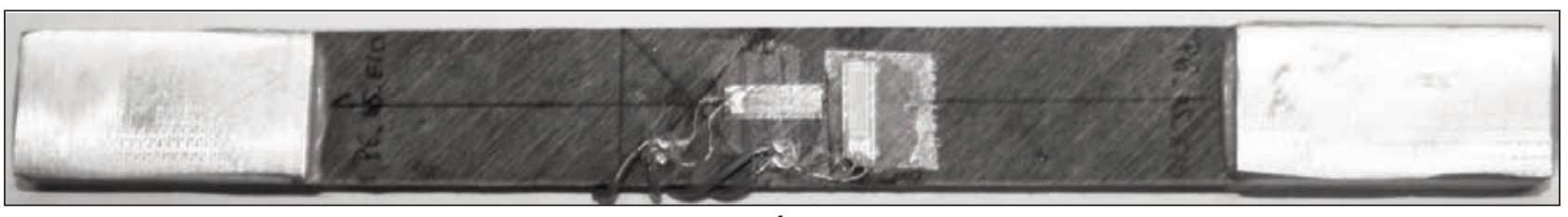

b

Fig. 1. Testing specimens: $a$ - Specimen used for stereocorelation; $b$ - Specimen used for viscoelastic testing 
stress, thus confirming the possibility of charging as high as $20 \mathrm{MPa}$.

This interval has been divided in four, obtaining increments of $5 \mathrm{MPa}$ for each stress level of the creep test. The duration was chosen to be one hour, while de recovery was chosen as 5 hours.

The reading of the four strain gages was made with a frequency of $0,1 \mathrm{~Hz}$. The resulting files were compiled with the help of a MatLab script with which data processing was made. It, firstly, averaged the readings from the pairs of strain gages, thus eliminating the possible flexion induced deformations and then calculated the shear deformation, according to Eq. 1.

$$
\gamma=\varepsilon_{x}-\varepsilon_{y}
$$

where $\gamma$ is the shear deformation, $\varepsilon_{x}$ - the longitudinal deformation and $\varepsilon_{y}$ - the transverse deformation.

It, then, divided the readings by the stress level at which they were recorded. The creep curves are presented in figure 5 . These will be later used to model the behavior.

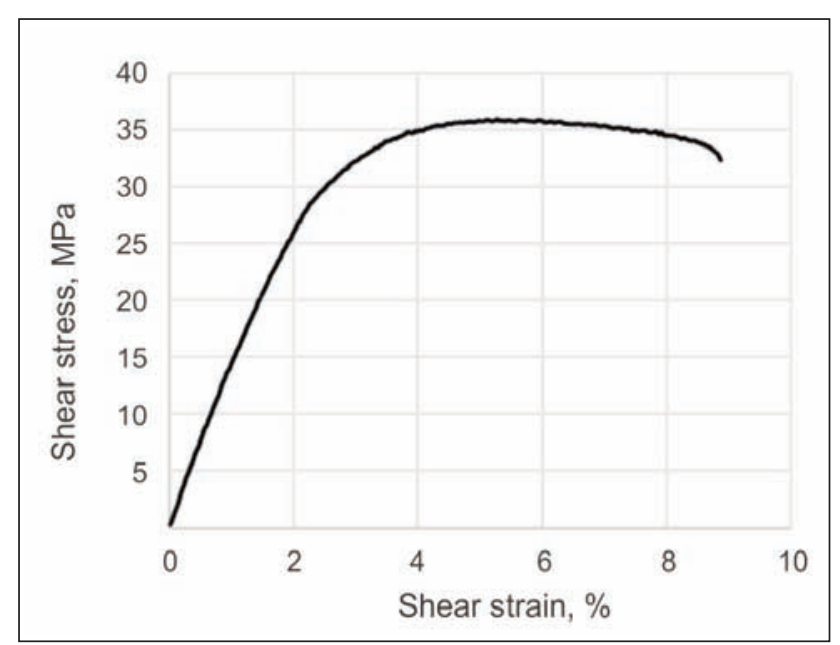

Fig. 2. Shear stress - shear strain curve of the traction test

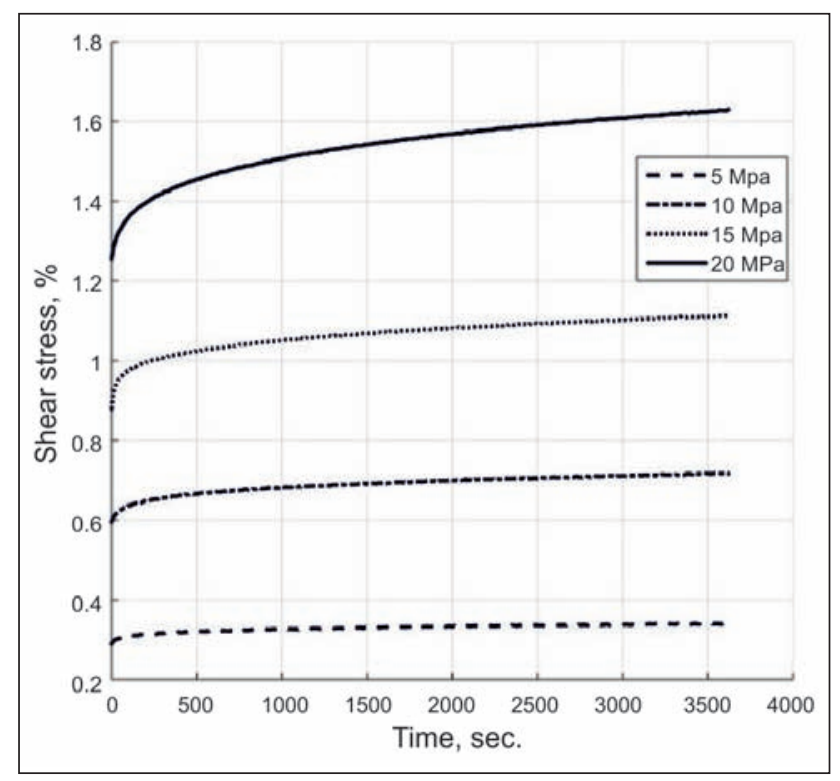

Fig. 3. One-hour creep curves

\section{MODEL DESCRIPTION}

The two models are based on rheology and consist of a series of springs and dashpots mounted in series or in parallel. Each spring comes with a stiffness in the equation and each dashpot with a viscosity. They are presented for a creep test, where the stress is constant.

The Zener model consists of a spring and dashpot mounted in parallel together with a second spring mounted in series to the two (figure 4 , left). Its equation is presented in Eq. 2. The Burger model consists of a Zener one mounted in series with a dashpot (figure 4 , right). Its equation is given in Eq. 3 .

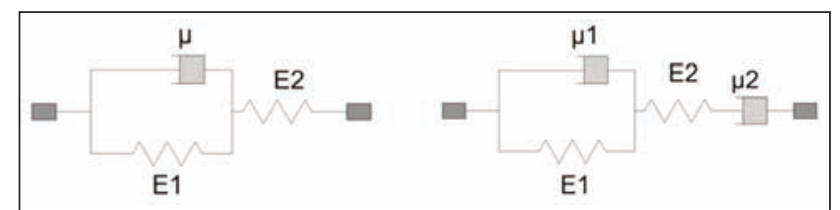

Fig. 4. The rheological models: left - Zener; right - Burger

$$
\begin{gathered}
\varepsilon_{t}=\sigma\left(\frac{E_{1}+E_{2}}{E_{1} E_{2}}-\frac{1}{E_{1}} \cdot \mathrm{e}^{-\frac{\mathrm{t}}{\tau}}\right) \\
\varepsilon_{t}=\sigma\left(\frac{E_{1}+E_{2}}{E_{1} E_{2}}-\frac{1}{\mu_{2}} \cdot t-\frac{1}{E_{1}} \cdot \mathrm{e}^{-\frac{\mathrm{t}}{\tau}}\right)
\end{gathered}
$$

Where $\tau$ is called the reduced time and is calculated as:

$$
\tau=\frac{\mu}{E_{1}}
$$

\section{PARAMETER IDENTIFICATION}

The procedure is made for a creep curve at a low stress level, in the lower parts of the linear domain. For the current work, the $5 \mathrm{MPa}$ creep curve has been used for fitting.

Firstly, at $t=0$, where the creep curve starts, it is possible to determine the instantaneous compliance. By replacing "t" with 0 in the models, $E_{2}$ is calculated.

Further on, an optimization method based on the least squares equation was used. In the case of the Zener model, it was implemented to determine $E_{1}$ and $\mu_{1}$, while for the Burger model, $E_{1}, \mu_{1}$ and $\mu_{2}$. The results of this optimization procedure are given in table 1 and the fitting is shown in figure 5 , for the 5 MPa creep curve.

Table 1

\begin{tabular}{|c|c|c|}
\hline \multicolumn{3}{|c|}{ ZENER AND BURGER MODEL PARAMETERS } \\
\hline Parameter & Zener & Burger \\
\hline $\mathrm{E}_{1}[\mathrm{MPa}]$ & 11,040 & 16,690 \\
\hline $\mathrm{E}_{2}[\mathrm{MPa}]$ & 1,719 & 1,719 \\
\hline$\mu_{1}[\mathrm{MPa} \cdot \mathrm{s}]$ & $5,549,000$ & $2,527,000$ \\
\hline$\mu_{2}[\mathrm{MPa} \cdot \mathrm{s}]$ & - & $84,440,000$ \\
\hline Error $[\%]$ & 3.6 & 1.8 \\
\hline
\end{tabular}




\begin{tabular}{|c|c|c|}
\hline \multicolumn{2}{|c|}{ Table 2} \\
\hline \multicolumn{2}{|c|}{ ERROR CALCULATION FOR THE TWO MODELS } \\
\hline Stress level & Zener (\%) & Burger (\%) \\
\hline $5 \mathrm{MPa}$ & 3.6 & 1.8 \\
\hline $10 \mathrm{MPa}$ & 6.5 & 5.2 \\
\hline $15 \mathrm{MPa}$ & 9.4 & 8.1 \\
\hline $20 \mathrm{MPa}$ & 17.5 & 16 \\
\hline
\end{tabular}

The errors are calculated as the maximum difference between the experimental result and the calculated one.

It is visible that, in the case of the $5 \mathrm{MPa}$ creep curve, the Burger model has a lower error than the Zener one, thus making it more suited for describing the behavior.

Once the parameters were calculated, the remaining three creep curves were compared with the two models. An analysis is made based on the maximum error between the calculated value for the two models and the experimental result. The maximum ones between the experimental curve and the model results are given in table 2 . The creep curves and the two equations are plotted in figure 5 .

It can be seen that, in the case of the first stress level, the error is low but it increases with the increase in stress for each creep level. Both models tend to describe just as well the viscoelastic behavior, with a difference of approximately $1.5 \%$ between the two. They both tend to give results lower than the experimental curves.

The fact that the two models, which are valid in the linear domain tend to diverge from the experimental results is a suggestion that the creep is nonlinear. As a result, these models would need to be adapted to take this nonlinearity into account. One such model is presented by Schapery [21]. It, however, requires a number of seven parameters to be fully defined, out of which, four are non-linear.

\section{CONCLUSIONS}

An experimental procedure of creep recovery tests was conducted in order to identify the visco elastic

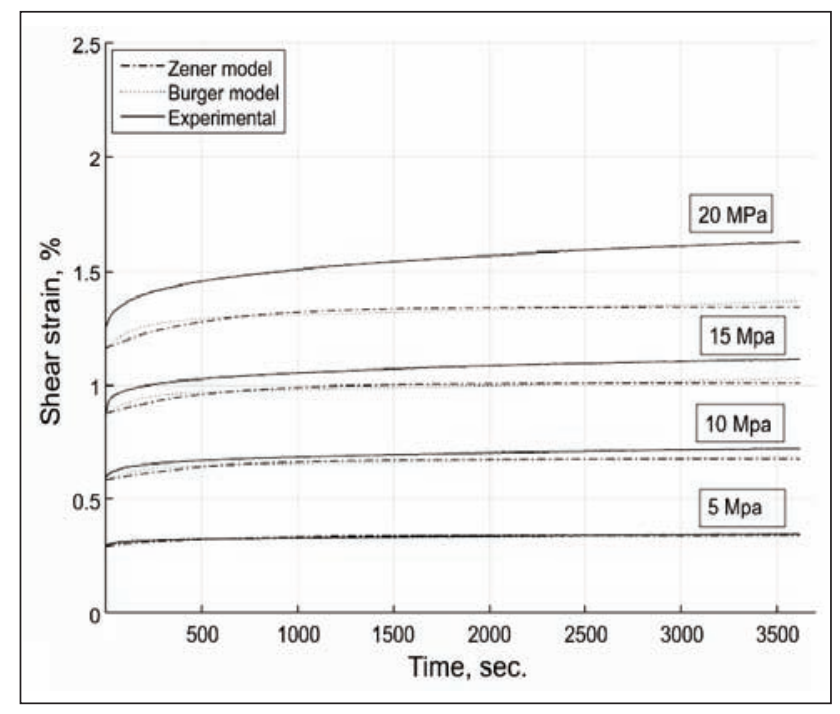

Fig. 5. Creep curves, model and experimental

characteristics of a unidirectional biocomposite laminate. The studied material was a $\pm 45^{\circ}$ fiber direction, which would highlight the shear behavior under a constant stress. The experiments were used to determine, firstly, the shear stress - strain curve, which was used to determine the stress levels for the creep - recovery experiments and, with the help of the latter, calculate the parameters of two rheological models, namely the Zener and Burger ones. A MatLab code was created with this purpose. The method used for the identification was based on a least squares equation. The fitting was made on the lowest level creep curve, which was considered on the linear domain.

Results showed that, for the first creep curve, the two models exhibit a small divergence, while for the other three, this error tended to increase with the increase of the stress level, suggesting that creep occurs in a nonlinear domain.

It is recommended that, in a future work concerning the flax fiber reinforced composites, on this direction, the nonlinearity is to be considered, with the usage of a more complex model, such as the one proposed by Schapery.

\section{BIBLIOGRAPHY}

[1] Flynn, J., Amiri, A., Ulven, C., Hybridized carbon and flax fiber composites for tailored performance, In: Materials \& Design, 2016, 102, pp. 21-29

[2] Wambua, P., Ivens, J., Verpoest, I., Natural fibres: Can they replace glass in fibre reinforced plastics?, In: Composites Science and Technology, 2003, 63, 9, pp. 1259-1264

[3] Meyers, M., Mechanical Behavior of MATERIALS, Cambridge University Press, 2008, ISBN-13: 978-0521866750.

[4] Gutierrez-Lemini, D., Engineering viscoelasticity, 2001

[5] Saunders, D. W., Creep and relaxation of nonlinear viscoelastic materials, 1978

[6] Miyano, Y., Nakada, M., Kasamori, M., Muki, R., Effect of physical aging on the creep deformation of an epoxy resin, In: Mechanics of Time-Dependent Materials, 2000, 4, pp. 9-20

[7] Hiel, C., Cardon, A. H., Brinson, H. F., The nonlinear viscoelastic response of resin matrix composite laminates, 1984 
[8] Luo, W. B., Wang, C. H., Zhao, R. G., Application of time-temperature-stress superposition principle to nonlinear creep of poly(methyl methacrylate), In: Key Engineering Materials, 2007, 340-341, pp. 1091-1096

[9] Mallick, P. K., Fiber-reinforced composites: materials, manufacturing, and design, 2008

[10] Tuttle, M. E., Brinson, H. F., Accelerated viscoelastic characterisation of T300/5208 Graphite - Epoxy laminates, 1985

[11] Mohan, R., Adams, D., Nonlinear creep-recovery response of a polymer matrix and its composites, In: Experimental Mechanics, 1985, no. September, pp. 262-271

[12] Pamuk, G., Ceken, F., Comparison of the mechanical behavior spacer knit cotton and flax fabric reinforced composites, In: Industria Textila, 2013, 64, 1, pp. 3-6

[13] Satyanarayana, K. G., Arizaga, G. G. C., Wypych, F., Biodegradable composites based on lignocellulosic fibers An overview, In: Progress in Polymer Science (Oxford), 2009, 34, pp. 982-1021

[14] Andre, N., Martin, M., Contribution à l'étude de paramètres influençant les propriétés mécaniques de fibres élémentaires de lin - corrélation avec les propriétés de matériaux composites, 2015

[15] Stamboulis, A., Baillie, C. A., Garkhail, S. K., Van Melick, H. G. H., Peijs, T., Environmental durability of flax fibres and their composites based on polypropylene matrix, In: Applied Composite Materials, 2000, 7, 5-6, pp. 273-294

[16] Zhang, Y., Li, Y., Ma, H., Yu, T., Tensile and interfacial properties of unidirectional flax/glass fiber reinforced hybrid composites, In: Composites Science and Technology, 2013, 88, pp. 172-177

[17] Célino, A., Fréour, S., Jacquemin, F., Casari, P., The hygroscopic behavior of plant fibers: a review, In: Frontiers in chemistry, 2013, 1, March 2016, p. 43

[18] Poilâne, C., Cherif, Z. E., Richard, F., Vivet, A., Ben Doudou, B., Chen, J., Polymer reinforced by flax fibres as a viscoelastoplastic material, In: Composite Structures, 2014, 112, 1, pp. 100-112

[19] Varna, J., Sparninš, E., Joffe, R., Nättinen, K., Lampinen, J., Time-dependent behavior of flax/starch composites, In: Mechanics of Time-Dependent Materials, 2012, 16, 1, pp. 47-70

[20] Houanou a K., Tchéhouali, A., Foudjet a E., Identification of Rheological Parameters of the linear Viscoelastic Model of two species of tropical woods (Tectona grandis Lf and Diospyros mespiliformis), In: Research Journal of Engineering Sciences, 2012, 1, 5, pp. 17-24

[21] Schapery a R., Nonlinear viscoelastic and viscoplastic constitutive equations based on thermodynamics, In: Mechanics of Time-Dependent Materials, 1997, 1, pp. 209-240

\section{Authors:}

\section{CONSTANTIN STOCHIOIU ${ }^{1,2}$ BENOÎT PIEZEL ${ }^{2}$ \\ AMEUR CHETTAH ${ }^{2}$ \\ STÉPHANE FONTAINE ${ }^{2}$ \\ HORIA-MIRON GHEORGHIU ${ }^{1}$}

${ }^{1}$ University POLITEHNICA of Bucharest (UPB),

Splaiul Independenței, 313, 060042, Bucharest, Romania

2DRIVE EA 1859, Université Bourgogne Franche-Comté,

49 Rue Mademoiselle Bourgeois, 58027Nevers, France

\section{Corresponding author:}

CONSTANTIN STOCHIOIU

e-mail: C.stochioiu@gmail.com 


\title{
Studying the corporate social responsibility in apparel and textile industry
}

\author{
DOI: $10.35530 / I T .070 .04 .1572$
}

DRAGOLJUB B. ĐORĐEVIĆ

MILOVAN VUKOVIĆ

SNEŽANA UROŠEVIĆ

NADA ŠTRBAC

ALEKSANDRA VUKOVIĆ

\section{REZUMAT - ABSTRACT}

Studiul responsabilității sociale a întreprinderilor în industria textilă și de îmbrăcăminte

În industria textilă și de îmbrăcăminte din țările în curs de dezvoltare, există o confuzie asupra definirii responsabilității sociale a întreprinderilor (RSI) și, în consecință, acest concept vag se reflectă în cercetarea fenomenului și a practicilor RSI. Întreprinderile mici și mijlocii și companiile mari doresc să încorporeze conceptul de responsabilitate socială a întreprinderilor (RSI) în cadrul strategiilor, politicilor și practicilor lor de afaceri, în special în era globalizării și a comerțului internațional. Acest studiu își propune să realizeze o introducere în domeniul responsabilității sociale a întreprinderilor (RSI), aplicat în industria textilă și de îmbrăcăminte. Prima parte a acestui studiu prezintă un rezumat al diferitelor definiții, teorii despre RSI și metode care au fost publicate de către specialiștii în domeniul RSI, atât în revistele din mediul academic, cât și în cele ale practicienilor. Întrucât campaniile mari integrează principiile RSI în politicile și practicile lor de afaceri, angajații trebuie să aplice valorile corporatiste adoptate. În partea a doua a acestui studiu, autorii au analizat diferitele cadre RSI aplicabile în practica din industria textilă și de îmbrăcăminte. Analiza a arătat că domeniul $R S I$ este în continuă dezvoltare, iar autorii oferă un set de recomandări cu privire la modul în care domeniul RSI poate fi aplicat în continuare în industria textilă și de îmbrăcăminte. În cele din urmă, ultima parte a acestui studiu subliniază unele aspecte metodologice care derivă din perspectivele teoretice adoptate în materie de RSI. De asemenea, se prezintă o analiză comparativă a diferitelor abordări de cercetare (cantitativă/calitativă, inductivă/deductivă, exploratorie/descriptivă /explicativă).

Cuvinte-cheie: responsabilitate socială a întreprinderilor (RSI), perspective teoretice, industria textilă/de îmbrăcăminte, abordări de cercetare

\section{Studying the corporate social responsibility in apparel and textile industry}

In the apparel and textile industry in developing countries, there is a confusion over the definition of CSR, and, consequently, this conceptual vagueness reflects itself on the research of the phenomenon and the practices of CSR. Small and medium enterprises and large companies are eager to incorporate the concept of corporate social responsibility (CSR) within their business strategies, policies and practices, especially in the era of globalization and international trade. This literature review articles aims to bring a better introduction to the field of corporate social responsibility (CSR) as studied by apparel/textile industry scholars. The first part of this review summarizes the different definitions, theories about CSR, and methods that have been used by management scholars working in the CSR field in both academic and practitioner management journals. As large corporations integrate the principles of CSR into their business policies and practices, company employees are expected to follow actions regarding the adopted corporate values. The authors in the second part of this review discuss different CSR frameworks applicable to the apparel/textile industry practice. The analysis shows that the CSR field is still evolving and the authors provide a set of recommendations on how to advance the CSR field to be applicable to the apparel/textile industry. Finally, the last part of this review highlights some methodological issues, originating from the adopted theoretical perspectives on CSR. A comparative review of different research approaches (quantitative/qualitative, inductive/deductive, explorative/ descriptive/explanatory) is also given.

Keywords: corporate social responsibility (CSR), theoretical perspectives, apparel/textile industry, research approaches

\section{INTRODUCTION}

"Social responsibility" is a term with a long history of use in the area of business management. According to Carroll, Howard Bowen was the first author who used this term, and, he stated in 1953 that social responsibility related to "the obligations of businessmen to pursue their policies, to make those decisions, or to follow those lines of action, which are desirable in terms of the objectives and values of our society" [1]. The extension of the concept to "corporate social responsibility" was attributed to the corporation's emerging prominence and leadership [1].

Corporate social responsibility, regardless of specific labelling, mainly means that business, apart from wealth creation, also has responsibilities for social issues created by business or by other causes [2]. Numerous abstract definitions have also been published in textbooks and papers, and, consequently, a number of scholars called for conducting research that will be focused rather on the practical level of 
CSR than the conceptual level. This paper supports this call and describes the current situation concerning CSR in practice of apparel/textile sector. Yet, there is a lack of this knowledge in regard to CSR development when the apparel/textile industry is at stake. As a relatively new term in the apparel and textile industry, Dickson and Eckman claim that it is important to clarify how CSR is used in this filed [3]. In fact, conceptualization of CSR in apparel and textile industry is a fundamental step in developing a theoretical base for this field [4].

This study first offers a short overview of corporate social responsibility (CSR) theories. The second part of this study attempts to clarify the concept of CSR as it relates to the vast array of apparel/textile business activities discussed by numerous authors. The last part of this paper pays attention to the methodological issues related to the CSR research in apparel/textile industry.

\section{THEORIES OF CORPORATE SOCIAL RESPONSIBILITY}

Various issues of CSR have been discussed for many years and these ideas have historical roots in Europe and worldwide [5]. From the theoretical standpoint, it is possible to discuss about various theories of CSR; and, all of them could be classified into four groups: (1) instrumental/wealth, (2) political/ social, (3) integrative, and (4) ethical theories. Within each theoretical branch there is a variety of approaches [6]. In this paper, more attention will be paid to the last (ethical) theoretical orientation.

Among integrative theories, created in order to integrate various social expectations from corporations, the "stakeholder management" and "corporate social performance" stand out. According to the "stakeholder view" of the firm, the term "stakeholder" can be defined as any group or individual who can affect or is affected by the achievement of the firm's objectives. These include entities such as: shareholders, employees, customers, suppliers, investors and society. Moreover, Freeman considered that this framework could be extended to other actors (external groups) such as: governments, competitors, consumer advocates, environmentalists, special interest groups (SIG) and media [7]. According to "corporate social performance" (CSP), business, beyond its economic and legal constraints, also has responsibilities for social issues caused by various activities.

Ethical theories offer various approaches such as: (1) normative stakeholder theory, (2) universal rights, (3) sustainable development, and (4) common good [3]. According to Matten and Crane, the stakeholder perspective is "a necessary process in the operationalization of corporate social responsibility" $[8, p$. 111]. Normative stakeholder theory (NST)-the core of normative perspective-represents a tool for making an ethical decision, and assumes that a corporation has a greater responsibility than just maximizing its profits. According to this theory, any socially responsible company is obligated simultaneously to pay attention to the "legitimate interests of all appropriate stakeholders", and, hence, has to "balance such a multiplicity of interests and not only the interests of the firm's stockholders" [6, p. 60]. Neither of these approaches relates to an entire range of issues included in CSR and, therefore, their combination seems to be an appropriate solution.

Starting from the 1990s, business systems are no more seen only as productive-economic entities (closed systems). Leadership of any apparel/textile company has put effort to improve, support and expand its activities, both in serving the domestic market and, mostly, with the aim to export and be competitive at the global market. In line with this, the concept of CSR is seen as a tool to increase economic performance. Also, many companies in the apparel/textile industry, having the possibilities of minimizing the costs of production, have started to outsource production facilities to Asia (mainly China and India), Africa, and, even South-East Europe. Therefore, the CSR concept appears as a consequence of the growing interdependence among numerous social groups (stakeholders), on the one hand, and the increased participation of society in business activities, on the other. Yet, CSR is a very heterogeneous theoretical discourse. It includes a variety of terms-occasionally used interchangeably during the 1980s and 1990s - to discuss corporate social responsibility: "corporate sustainability", "corporate citizenship", "corporate responsibility", "corporate governance", "corporate accountability", "ethical business", "sustainable entrepreneurship", "sustainability", etc. These alternative overlapping views are consistent with the earlier definitions of social responsibility, especially with that suggested by Carroll - the social responsibilities of business "encompass the economic, legal, ethical, and discretionary expectations that society has of organizations at a given point in time" [9, p. 500].

The European Commission offers a slightly better description of this concept. It defines CSR as "a concept whereby companies integrate social and environmental concerns in their business operations and in their interaction with their stakeholders on a voluntary basis" [10]. In other words, CSR is a company's commitment to conduct its activities in an economically, socially and environmentally sustainable manner whilst balancing the interests of diverse stakeholders. Similarly, the World Business Council for Sustainable Development (WBCSD) defined CSR as "the commitment by business to behave ethically and contribute to economic development while improving the quality of life of the workforce as well as of the local community and society at large" [11-12].

Although Carroll's model of the four responsibilities has been widely used over the years, it has some drawbacks. First of all, Carroll's original categorization did not fully capture the overlapping nature of the four categories - economic, legal, ethical and philanthropic - and, furthermore, "philanthropic responsibility should be placed in all categories because philanthropic activities are voluntary and therefore should 
not be considered responsibilities per se" [13, p. 43]. Therefore, it is not surprising that Carroll and Schwartz revisited (2003) the original model of CSR, aiming to overcome its limitations, offering an alternative model - the "Three-Domain Model of CSR" [14, p. 509].

This new model of CSR outlined three main responsibilities (economic, legal and ethical), while the former fourth category (philanthropic responsibility), was placed in both the economic and ethical domains. According to Carroll and Schwartz, the three domains overlap, as depicted in their Venn diagram, and, consequently, it is possible to identify seven possible types of CSR responsibility: purely economic, purely legal, purely ethical, economic/ethical, economic/legal, legal/ethical, and, finally, economic/ legal/ethical. Regarding the limitations of the "Three Domain Model of CSR", the authors point out that economic, legal and ethical responsibilities are "inseparable and interwoven", and, consequently, any action cannot really be recognized as either purely legal, purely ethical or purely economic [14, p. 520]. The relative importance that one assigns to each of the three CSR dimensions proposed by Carroll and Schwartz is not fixed. It may be, what is common in an empirical study, a reflection of respondents' social responsibility preference (attitude). Michailides and Lipsett called this the "corporate social responsibility orientation” (CSRO) [15, p. 300].

Although numerous definitions of CSR tend to be applicable to all types of organizations, they cannot fulfil this task. Dahlsrud, ten years ago, analyzed no fewer than 37 definitions (1980-2003), and noticed that, for the most part, these definitions are congruent [16]. Various definitions of CSR rather tend to describe this phenomenon than to offer an explicit definition of what corporate social responsibility should be. Dahlsrud also identified five dimensions that are most frequently tied to the CSR concept: stakeholder, social, economic, voluntariness and environmental. This apparent connection implies that any CSR initiative has to consider the economic and social interests of relevant stakeholders in a voluntary way [17]. Some scholars suggest an extension of the CSR concept in order to incorporate the international aspect of business activities, and, call for socalled "global responsibility" [1]. It has been known for a long time that contemporary business extends national borders (primarily due to the globalization process) and that fact has already been taken into account in many similar concepts such as that of "business ethics". Otherwise, the term "social", as Dickson and Eckman rightly noticed, was never limited geographically, and, hence, the notion of "global responsibility" in the context of corporate business offered "nothing beyond what earlier authors had defined as social responsibility" [17, p. 181].

The vagueness of numerous CSR definitions impedes their corporate implementation, and, as Van Marrewijk observed, does not allow academic debate [13]. When we talk about the apparel and textile industry, social responsibility and CSR are not only new concepts, as mentioned earlier, but also still relatively new terms [3].

\section{CORPORATE SOCIAL RESPONSIBILITY IN APPAREL AND TEXTILE INDUSTRY}

Starting in the 1970s, the apparel/textile industry began to reorganize continuously thanks to the intensification of the globalization process that implies the removal of trade barriers and the acceleration of the flow of goods, services, capital and labor [18-20]. The apparel/textile industry capacities of large global corporations have been increasingly outsourced from once traditional industrial regions of the developed world. Bearing in mind that apparel and textile production is a highly labor-intensive activity, the leading corporations in this field, searching for cheap labor, outsource their production processes into highly populated regions (above all, China and India), which are characterized by a surplus of labor and a deficit of work, and, consequently, significantly lower income. This has mainly contributed to the apparel/textile industry, more so than other branches, acquiring an extremely global character [21]. Despite this, the apparel/textile industry witnesses highly expressed regional differences that relate to state regulations, employment conditions, environmental protection, and amount of income. This heterogeneity forces the large textile corporations to create different business conditions in certain parts of the world, which does not necessarily have to be in line with the common ethical norms.

The European apparel/textile companies are faced with more stringent regulations in the area of environmental protection and higher labor costs [22]. Therefore, the apparel/textile sector in Europe increasingly instigates innovation activities both in the processes and in the high-quality products. On the other hand, displacing the apparel/textile industry capacities to less developed parts of the world has brought about a series of positive changes on the social plane. The development of the apparel/textile industry has contributed to the economic renewal of the developing countries by enabling the opening of a great number of workplaces that do not require specialized knowledge and skills. A large number of people from marginalized social groups (particularly women) would find it hard to secure employment without investing in the apparel/textile industry in the rural areas of these countries. This is particularly important bearing in mind the fact that from approximately 26.5 million of employees in the apparel/textile sector worldwide, $70 \%$ are women. Also worth mentioning is that language barriers do not represent a serious obstacle for getting involved in the production processes of the apparel/textile industry, which facilitates the path toward workplaces for migrant labor. All of this leads to the developing countries achieving three quarters of the global apparel export, i.e. around $50 \%$ of the textile export [23-24].

The growing international character of the apparel/ textile industry in recent decades, described above, 
is followed by an increased interest in various issues of different stakeholders in this industry. Consequently, the models of CSR applicable to the apparel/textile industry have become the subject of numerous studies. The study conducted by Dickson and Eckman is one of the influential studies in the area of CSR in the apparel industry [3]. The authors used survey research methods to determine apparel and textile scholars' definition of the term "socially responsible apparel/textile business". Active members of the International Apparel and Textile Association (ITAA) participated in this survey. Of 523 ITAA members included in the sample, 87 completed the survey for a response rate of $16.6 \%$. It is important to note that all the respondents were ITAA members associated with academic institutions, and almost two thirds of them were employed in academic positions. A wide scope of social responsibilities topics in this survey was recognized as important for apparel and textile teaching staff. To the vast majority of respondents $(87 \%)$, the working conditions were important, and almost $80 \%$ considered child labor, consumerism and environmental degradation as important to point out. Based on the obtained responses from the conducted survey, Dickson and Eckman found out a definition of a socially responsible apparel/textile business as follows:

- An orientation encompassing the environment, its people, the apparel/textile products made and consumed, and the systematic impact that production, marketing, and consumption of these products and their component parts has on multiple stakeholders and the environment.

- A philosophy that balances ethics/morality with profitability, which is achieved through accountability-based business decisions and strategies.

- A desire for outcomes that positively affect, or do very little harm to, the world and its people $[3, p$. 188].

The Global Reporting Initiative (GRI) is the most frequently used framework for providing guidance on CSR performance disclosure. The GRI has also developed specific sector supplements, including a pilot version specifically for the apparel and footwear industry - Apparel and Footwear Sector Supplement (AFSS). The AFSS provides a definition of CSR reporting as a "practice of measuring, disclosing and being accountable for organizational performance while working towards the goal of sustainable development provides a balanced and reasonable representation of the sustainability performance of the reporting organization positive and negative contributions" [26, p. 55]. Since this concept of CSR encompasses a wide range of issues such as "human rights", "labor", "social", "environmental", "product responsibility" and "economic issues", it is difficult to achieve that all dimensions be comprehensively examined in one study [25]. This classification is similar to that suggested by Kunnari et al.; social impacts are also divided in six categories: "environment", "economics", "employment", "housing and community", "local livelihoods" and "health" [27].
The ISO 26000 standard can also be used as a framework to address the CSR in apparel and textile industry. The ISO 26000 has divided CSR into seven core themes: "organizational governance", "human rights", "labor practices", "the environment", "fair operating practices", "consumer issues" and "community involvement and development". For every theme (subject), a number of associated issues are listed. For instance, the environment includes prevention of pollution, sustainable resource use, and protection of the natural environment. The ISO 26000 standard offers guidance on how organizations can operate in a social responsible way, contributing to the health and well-being of society. ISO 26000 standard states that the engagement with stakeholders is crucial to social responsibility (especially with those such as employees, customers, affected communities and the general public), and, also, outlines the CSR as companies' and other organizations' contribution to sustainable development [28].

\section{QUALITATIVE RESEARCH METHODS IN CSR APPAREL/TEXTILE INDUSTRY}

There is a number of research approaches to study corporate social responsibility in the apparel and textile industry, especially in terms of its practice. First of all, the researchers themselves create a general direction of a particular study. A researcher's preunderstanding and adopted theoretical perspective and personal experiences, for instance, direct the research in many cases. Gummesson considers that a pre-understanding may be beneficial in order to understand the business culture in which the company operates. Among some drawbacks, the problem of reduced openness to new information and innovation might be mentioned [29]. In terms of apparel/textile context, the focus of this research could be on understanding perceptions of CSR among manufacturers in developing countries; mostly in India, China, etc. Because little research exists which examines manufacturer perceptions in apparel/textile, a better understanding is needed. Unlike developing countries, some other issues of CSR in apparel/textile industry have been examined in developed world such as, for instance, companies' motivation factors to adopt CSR practice, relationship between CSR and economic performance and green fashion and sustainability. Therefore, various issues on CSR might be somewhat sensitive in apparel/textile industry such those relating to factory working conditions and the treatment of workers often arise. Also, if the study is emic in nature and aims to capture the insider's perspective, then qualitative methodologies are typically the most appropriate. For example, Gupta has successfully used a qualitative research design (in particular, ethnography) in his study of CSR in apparel/ textile industry in India [14].

Although research within the area of CSR has increased over time, it seems that the research at the practical level is limited. In apparel and textile industry, exploratory research may lead to useful knowledge. 
As an excellent example of qualitatively, exploratory research is a recently conducted study of the Romanian business retail with garment products within the context of globalization and sustainable development [30]. The method used for conducting this research was the survey, the technique employed was the in-depth interview and the instrument was the discussion guide. The research confirms one of given assumptions that the existing ethical principles, if implemented within the business retail with garment products, will guarantee a balanced development, in compliance with environmental protection regulations.

Despite widely used quantitative methodologies in studies related to CSR, the advantages of qualitative methods should not be underestimated. Namely, qualitative research attempts to understand the real world for an individual or a group of individuals and how they see themselves and their relations to the "environment, people/society, systems, institutions, business, selections of business partners, profits, and animal rights", let us name these entities according to the framework suggested by Dickson and Eckman [3, p. 186]. In other words, qualitative research focuses on words, narratives, observations, visual portrayals, meanings of used symbols, interpretations and other expressive descriptions [29]. The advantages of the case method have been confirmed in recently conducted research on CSR in apparel/ textile companies, resulting in numerous papers published during the last two decades. Case study research methods are applicable to study of various aspects of CSR in apparel/textile industry. The vast majority of these issues requires a rich understanding of the context as well as an extensive and in-depth description of a given phenomenon. The categories of CSR, considered in this paper, reflect the impacts of apparel/textile industry on a general scale, but in any research of this type they are used as guidelines, through which the social aspects are conceptualized. The actual scrutiny of the social dimensions is carried out on the basis of themes, and associated issues, found out from empirical data. And, doing so, the characteristics of the selected case are emphasized.

\section{CONCLUSION}

In recent decades, the apparel/textile industry has been facing numerous demands from various interest groups. One of the crucial factors for the long-lasting success of major apparel/textile companies is the ability to reconcile their interests with the interests of communities in which they operate. Consequently, this type of industry and its management, along with other industries relating to numerous stakeholders, needs to adopt a more comprehensive approach in order to address these demands. Since the relationship between local communities and apparel/textile companies is the most important from the social standpoint, the vast majority of studies (mentioned in the review) relied on the integrative theoretical perspectives (stakeholder management) and particular methodology - the case method.

Corporative social responsibility is becoming a concept whose different aspects are increasingly investigated in the apparel/textile industry. Among the topics that mainly stem from the ISO 26000 standard, the most commonly examined are those that are related to human rights and working conditions, particularly in the apparel/textile sector of the developing countries. The environmental protection issues also represent a significant area in CSR analysis.

On the basis of the analysis of the CSR concept from the standpoint of the apparel/textile sector it can be concluded that responsibility moves between two opposed orientations-economic responsibility, on the one hand, and ethical and philanthropic responsibility, on the other. Numerous issues encountered by the apparel/textile sector create the need for combining various ethical orientations. Large corporations within this branch of economy, as well as small and medium enterprises, gain profit by offering their customers high-quality products, thus improving their own reputation.

\section{ACKNOWLEDGEMENT}

Prepared as a part of the project Sustainability of the Identity of Serbs and National Minorities in the Border Municipalities of Eastern and Southeastern Serbia (179013), conducted at the University of Niš - Faculty of Mechanical Engineering, and supported by the Ministry of Science and Technological Development of the Republic of Serbia.

\section{BIBLIOGRAPHY}

[1] Carroll, A., Corporate social responsibility, In: Business \& Society, 1999, 38, 3, pp. 268-295

[2] Carroll, A., The pyramid of corporate social responsibility: toward the moral management of organizational stakeholders, In: Business Horizons, 1991, 34, pp. 39-48

[3] Dickson, M.A., Eckman, M., Social responsibility: the concept as defined by apparel and textile scholars, In: Clothing \& Textiles Research Journal, 2006, 24, 3, pp. 178-191

[4] Winakor, G., Research in fashion merchandising - the need for a theoretical base, In: Clothing \& Textiles Research Journal, 1988, 7, 1, pp. 31-35

[5] Carroll, A., The Oxford handbook of corporate social responsibility, Oxford University Press, Oxford, 2008

[6] Garriga, E., Melé, D., Corporate social responsibility: mapping the territory, In: Journal of Business Ethics, 2004, 53, pp. $51-71$

[7] Freeman, E., Strategic management: a stakeholder approach, Pitman, Boston, 1984 
[8] Matten, D., Crane, A., Corporate citizenship: Toward an extended theoretical conceptualization, In: The Academy of Management Review, 2005, 30, 1, pp. 166-179

[9] Carroll, A.B., A three-dimensional conceptual model of corporate performance, In: Academy of Management Review, 1979, 4, pp. 497-505

[10] European Commission (2001), Commission Green Paper 2001: Promoting a European framework for corporate social responsibility, COM (2001)366 Final

[11] World Business Council for Sustainable Development, Corporate social responsibility: Meeting changing expectations, Geneva, Switzerland: World Business Council for Sustainable Development, 1999

[12] Bouten, L., Everaert, P., Liedekerke, L. V., Moor, L. D., Christiaens, J., Corporate social responsibility reporting: $A$ comprehensive picture? In: Accounting Forum, 2011, 35, pp. 187-204

[13] Schwartz, M.S., Carroll, A.B., Corporate social responsibility: a three-domain approach, In: Business Ethics Quarterly, 2003, 13, 4, pp. 503-530

[14] Gupta, M., Corporate social responsibility in the global apparel industry: an exploration of Indian manufacturers' perceptions (dissertation), University of north Carolina: Greensboro, 2012

[15] Michailides, T.P., Lipsett, M.G., Surveying employee attitudes on corporate social responsibility at the frontline level of an energy transportation company, In: Corp. Soc. Responsib. Environ. Mgmt., 2013, 20, pp. 296-320

[16] Dahlsrud, A., How corporate social responsibility is defined: an analysis of 37 definitions, In: Corp. Soc. Responsib. Environ. Manag., 2008, 15, pp. 168-182

[17] Van Marrewijk, M., Concepts and definitions of CSR and corporate sustainability: Between agency and communion, In: Journal of Business Ethics, 2002, 45, 2/3, pp. 95-105

[18] Dicken, P., Global shift: Mapping the changing contours of the world economy, $6^{\text {th }}$ ed., London: Sage publications, 2011

[19] Dabija, D.C., Pop, N., Postelnicu, C., Ethics of the garment retail within the context of globalization and sustinable development, In: Industria Textila, 2017, 67, 4, pp. 270-279

[20] Tudor, L., Changes in textile and clothing industry, In: Industria Textila, 2018, 69, 1, pp. 37-42

[21] Perry, P., Towers, N. (2013), Conceptual framework development for CSR implementation in fashion supply chains, In: International Journal of Physical Distribution \& Logistics Management, 2013, 43, 5-6, pp. 478-500

[22] Eurostat, European business: facts and figures, 2009

[23] UNDP EC, Turkey corporate social responsibility: baseline report, 2008

[24] Vuković, M., Urošević, S. Vuković, A., Korporativna društvena odgovornost u tekstilnoj industriji In: Tekstilna Industrija, 2017, 65, 2, pp. 4-11

[25] Woo, H., Jin, B., Culture doesn't matter? The impact of apparel companies' corporates social responsibility practices on brend equity, In: Clothing and Textile Research Journal, 2016, 34, 1, pp. 20-36

[26] GRI, Sustainability reporting guidelines \& apparel and footwear sector supplement, Amsterdam, the Netherlands; Electronic Pilot Version: GRI, 2011

[27] Kunnari, M, Niemelä, M., Suikkanen, A, Kaivoshankkeiden käynnistämisvaiheiden ennakoidut sosiaaliset vaikutukset ja vaikutusten hallinnan tutkimusohjelma, Lapin yliopiston yhteiskuntatieteellisiä julkaisuja B. Lapin yliopiston yhteiskuntatieteiden tiedekunta, Rovaniemi, 2008

[28] ISO, Guidance on social responsibility, ISO 26000: 2010, IDT, 2010

[29] Gummesson, E., Qualitative methods in management research, Sage Publications Inc., Thousand Oaks, 2000

[30] Miron, A., Ciobanu, L., Matoschi, O., Furdui, L.M., Pruteanu, M.E., The restructuring of peasant households under the impact of urbanization by intensifying the knowledge transfer process and the collaboration with the textile industry, In: Industria Textila, 2014, 65, 3, pp. 173-178

Authors:

DRAGOLJUB B. ĐORĐEVIĆ ${ }^{1}$, MILOVAN VUKOVIĆ², SNEŽANA UROŠEVIĆ², NADA ŠTRBAC ${ }^{2}$, ALEKSANDRA VUKOVIĆ $^{3}$

${ }^{1}$ Faculty of Mechanical Engineering, University of Niš, Aleksandra Medvedeva 14, Niš, Serbia, e-mail: brkab@junis.ni.ac.rs

${ }^{2}$ Technical Faculty in Bor, University of Belgrade, Vojske Jugoslavije 12, Bor, Serbia, e-mail: mvukovic@tfbor.bg.ac.rs

${ }^{3}$ High Railway School of Professional Studies, Zdravka Čelara 14, Beograd, Serbia

Corresponding author:

SNEŽANA UROŠEVIĆ

e-mail: surosevic@tfbor.bg.ac.rs, snezanaur@gmail.com 


\title{
Digitisation and Industry 4.0 in the Portuguese T\&C sector
}

\author{
DOI: $10.35530 / I T .070 .04 .1612$
}

HA LUU

ANTÓNIO DINIS MARQUES

FERNANDO FERREIRA

\section{REZUMAT - ABSTRACT}

\section{Digitalizarea și Industria 4.0 în sectorul textile şi îmbrăcăminte din Portugalia}

Industria 4.0 este un subiect cheie în discuția despre viitorul industriei textile și de îmbrăcăminte (T\&C) din Europa. Această a patra Revoluție industrială este o viziune, o schimbare importantă a paradigmei actuale, capabilă să facă convergența între lumea reală și cea digitală în viitoarea "fabrică inteligentă". Integrarea Sistemelor fizico-cibernetice (CPS), Internetul Lucrurilor (IoT), Analiza Big Data și Cloud Computing, Inteligența Artificială, Robotica, Modelarea Virtuală sau Digitalizarea proceselor industriale reprezintă câteva dintre pricipalele subiecte ale acestor noi provocări. Tehnologiile precum dispozitivele cu coduri de bare, RFID, senzori, Bluetooth, GPS sau simulatoare 3D încep să fie prezente în industria textilă și de îmbrăcăminte. Acest articol va prezenta modul în care o companie producătoare de îmbrăcăminte (GUIMA, SOMELOS SGPS) își definește strategia pentru a face față cerințelor clienților și părților interesate. Pentru a adapta teoriile și modelele cunoscute din cadrul 14.0 la realitatea companiei GUIMA, precum sistemul RFID în tesături și accesorii pentru a permite actualizarea în timp real a stocurilor, toată planificarea se face cu sistemul loS, iar încadrările și comenzile de producție sunt asistate de un sistem 3D și în diferite loturi sunt încorporate etichete RFID. Companiile TIC sunt parteneri deosebit de importanți în acest parteneriat, dar și instituțiile de învățământ superior, comunitatea științifică și centrele tehnologice.

Cuvinte-cheie: digitalizare, sisteme fizico-cibernetice, RFID, fabrică inteligentă

\section{Digitisation and Industry 4.0 in the Portuguese T\&C sector}

Industry 4.0 is a key topic in the discussion about the future of Textile and Clothing (T\&C) industry in Europe. This $4^{\text {th }}$ Industrial Revolution is a vision, an important change of the current paradigm, able to make the convergence between real and digital world in the future "smart factory". The integration of Cyber-Physical Systems (CPS), the Internet of the Things (IOT), the Big Data Analytics and Cloud Computing, Artificial Intelligence, Robotics, Virtual modelling or Digitisation of the industrial processes are some of the main topics in this new challenges. Technologies as barcode devices, RFID, sensors, Bluetooth, GPS or 3D simulators starts to be present in the textile and clothing industry. This article will present how a clothing company (GUIMA, SOMELOS SGPS) is defining its strategy to face the demanding from their clients and stakeholders. In order to adapt the theories and models known from 14.0 to GUIMA's reality, as RFID in the fabrics and accessories to allow real-time updates of the stocks, all the planning is done with the loS system, the cutting plans and production orders are assisted by a 3D system and the different batches are incorporated RFID tags. The ICT companies are critical partners in this partnership, but also the HEl, the scientific community and technological centres.

Keywords: Digitisation, Cyber-Physical Systems, RFID, smart factory

\section{INTRODUCTION}

Industry 4.0 is a key topic in the discussion about the future of Textile and Clothing (T\&C) industry in Europe. This $4^{\text {th }}$ Industrial Revolution is a vision, an important change of the current paradigm, able to make the convergence between real and digital world in the future "smart factory". The integration of CyberPhysical Systems (CPS), the Internet of the Things (loT) and Internet of Services (loS), the Big Data Analytics and Cloud Computing, Artificial Intelligence, Robotics, Virtual modelling or Digitisation of the industrial processes are some of the main topics in this new challenges [1]. The Digital Economy and Society Index 2017 shows that some Portuguese companies have integrated the Digital Technology in their processes: $44 \%$ of them are using Electronic Information
Sharing (EIS) and 8\% RFID (figure 1), but this data is different among industrial sectors [2].

Portugal has an important T\&C industry with more than 140000 workers, produces more than $€ 6000$ million, mainly to export [3]. This traditional and mature industry is facing these challenges and needs to prepare the correct approach to overcome future

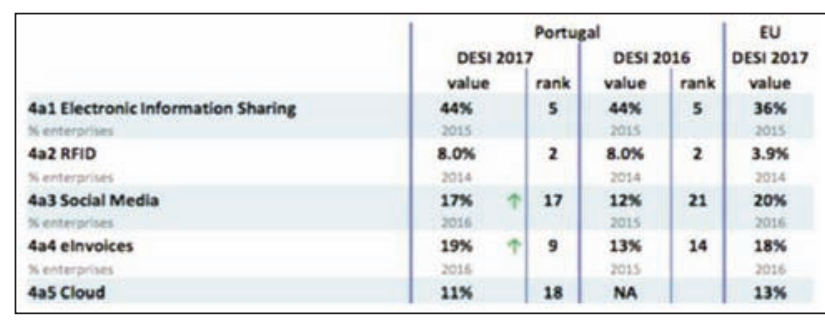

Fig. 1. Index of Integration of Digital Technology in Portugal and Europe 
difficulties and risks. Technologies as barcode devices, RFID, sensors, Bluetooth, GPS or 3D simulators starts to be present in the textile and clothing industry. The digitisation of the manufacturing is an ongoing approach in many factories, but requires skills and resources to be fully implemented [4].

This article will present how a clothing company is defining its strategy to face the demanding from their clients and stakeholders. But this new strategy to implement digitisation of the manufacturing in $T \& C$ is demanding also from their suppliers and other partners. The ICT companies are critical partners in this partnership, but also the HEI, the scientific community and technological centers and national authorities, as it happens in other countries [5]. CAD systems and automatic cutting it is been already used in GUIMA, and also IT in the stocks and warehouse, but the total integration of the data and digitisation of processes is not complete.

\section{EXPERIMENTAL APPROACH}

Apparel and footwear industries are considered "lowtech" industries, but already started the transition to a new technological level. This is the main aim to study the real application of some concepts and elements of Industry 4.0, including the integration of Digital Technology in the manufacturing processes of the Fashion Industry, mainly in Apparel and Footwear sectors.

As main result it is expected to obtain a characterization of a real case (Portuguese apparel company GUIMA, SOMELOS Group) concerning the integration of digital technology in the manufacturing processes and operations, quality, efficiency and productivity. There is a technological company inside the SOMELOS Group, called FLUXODATA - Aplicações Informáticas, Lda, with expertise and staff to develop, implement and control new ICT solutions to all the SOMELOS Group companies. Nowadays, the FLUXODATA is a ICT company having solutions to other T\&C firms, using an integrated module of textile solutions to manage and monitor daily industrial processes.

Qualitative research and case study methodology is of great convenience when the researcher wants a deep understanding of the context and the research process, and is adjusted to exploratory and explanatory studies of certain events or situations. This is also the strategy that allows to the researchers obtain holistic and relevant features of real events, regardless of the element of analysis is related with an individual, group or organization [6]. This is the opportunity to get a holistic view of a process, and is also a significant advantage for the case study strategy, when it is chosen [6]. Yin considers that a case study "is an empirical inquiry that investigates a contemporary phenomenon in depth and in the context of real life, explicitly when the boundaries between phenomenon and context are not clearly evident" (p.18) and are particularly useful when the researchers want to depth understand a specific organization or situation as it is with GUIMA [6]. Simons states that case study "is a deep exploration of multiple perspectives of the complexity and uniqueness of a particular project, a policy, an institution, a program or a system in a real-life context" (p. 21) [7]. The linkage between GUIMA, FLUXODATA and SOMELOS TECIDOS as main fabric supplier (all SOMELOS Group companies) was the criteria to choose these cases.

\section{RESULTS AND DISCUSSION}

The Portuguese companies in traditional, mature and "low-tech" sectors as they are apparel and footwear are facing the new challenges of digitisation according their own resources and available skills. The starting point to the different companies varies inside the sectors and according the existence or not of strong clusters. In 2012, GUIMA started an analysis of the manufacturing processes and a reorganization along the shop-floor. With the support of ICT FLUXODATA, the work began with the necessary development of tools to digitalize all the processes from warehouse, reception of the fabrics and accessories, passing through the areas of production, quality control, follow-up and delivery to the customers. Four years later, the software "FLUXOCONF" was implemented in the GUIMA as an internal ICT solution to support warehouse's operation, shop-floor assembly control, production efficiency and manufacturing times. To accomplish these tasks, the software answer to five items: i) which batches are ready to go into production; ii) identify in real time what is in working process; iii) evaluation of productivity and efficiency levels of each worker; iv) follow-up of the batches and production orders in the process (according planning department); v) measure the global efficiency and production costs.

SOMELOS TECIDOS is the main GUIMA's fabrics supplier. SOMELOS Group is a vertical textile company, starting its industrial process with spinning operations, warping and sizing, weaving, dyeing and finishing, clothing production, and it ends with other textile services (software/ICT and industrial maintenance). FLUXOMES is the manufacturing execution system (MES) developed by FLUXODATA supporting the production management and control in the shopfloor, such as production planning and scheduling, material delivery and control, product quality management and control, production costs and operation's time control, and equipment management and maintenance inside the SOMELOS Group (figure 2). This software solution also is sold to other textile companies as software/ICT services.

The new industrial challenges in this new millennium are identified as "collaborative production management and control" using networking manufacturing technologies such as agile manufacturing, collaborative manufacturing, supply chain management, e-manufacturing and e-commerce [8], and searching for innovation themes as "Smart, high-performance materials", "Advanced digitised manufacturing, value 


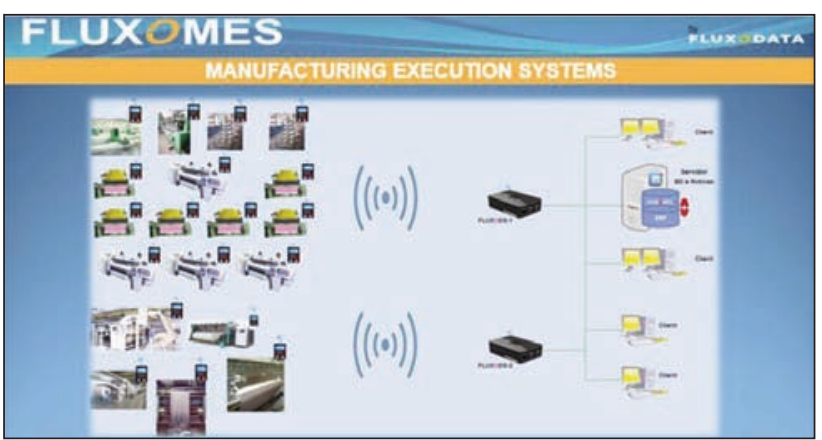

Fig. 2. FLUXOMES, manufacturing execution system from FLUXODATA

chains and business models", "Circular Economy and Resource Efficiency" and, finally, "High value added solutions for attractive growth markets" [9].

Considering the existing technology in shop-floor (warehouse, cutting, sewing machinery and transport between workstations), CAD/CAM to prepare the cutting plan, MES, ERP and MRP solutions, the analysis of future implementations is necessary and critical to the company.

In the warehouse, RFID can be used to identify the different fabrics, accessories and other materials stored in the racks, and barcodes as well. Smart sensors and wireless networks can be used to complete the ITC solutions available in this manufacturing sector. Furthermore, the implementation of these technologies and systems will help the commercial team and the administrators to adjust deadlines and optimize deliveries (GUIMA and SOMELOS TECIDOS have own products and collections, some of them to fast fashion industry, where the quick-response and short delivery times are critical). The production planning in GUIMA already benefits from FLUXOMES software and involves all the SOMELOS Group.

The cutting room has a CAD software to prepare the cutting plan according the customer order. The CAD workers place the different pattern pieces in the cutting plans and prepare the markers with the best solution (fabric usage, cutting time and productivity). With digitisation is possible to select the most suitable fabric rolls, reducing the fabric leftovers and finding the best width to achieve fabric savings. Spreading and cutting operations are monitored (using barcode scanners), providing reports that can be used for MRP (Material Requirement Planning) of further manufacturing processes [10]. Assembly operations will follow the technical instructions and get in workflow in batches with RFID tags (figure 3 ).

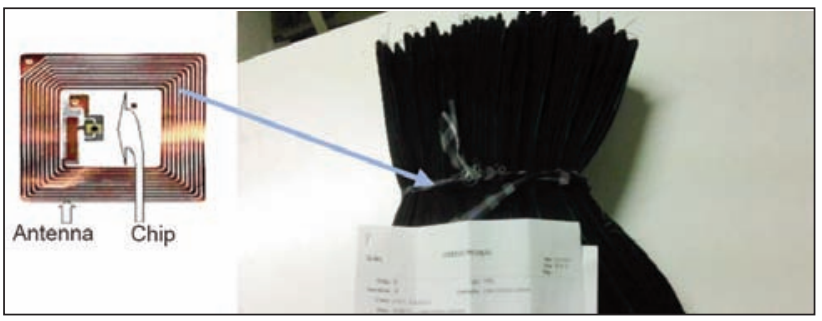

Fig. 3. Batch with RFID tag
All GUIMA sewing machines (and other machines) have a barcode reader where the operator inserts information's new batch. After that, the operator does the operations, the system records times and calculates efficiencies. Some activities of automation in clothing manufacturing system were considered before, such as workplace layout, work study analysis, time study and line balancing. To achieve next level in 14.0 process, it is necessary to implement RFID in all lean production (figure 4). The smart factory requires Cyber-Physical Systems allowing a continuous interaction and exchange of information, not only between operators, but also between operators and machines, and machine-to-machine [11]. Jiang defines two different CPS architectures in smart factories: CPS 5C Architecture and CPS 8C Architecture [12]. The CPS 5C was proposed by Lee et al [13] and has five levels: connection; conversion; cyber; cognition; configuration. GUIMA is doing first steps in this CPS model and needs to improve the skills of workers and machine's interface.

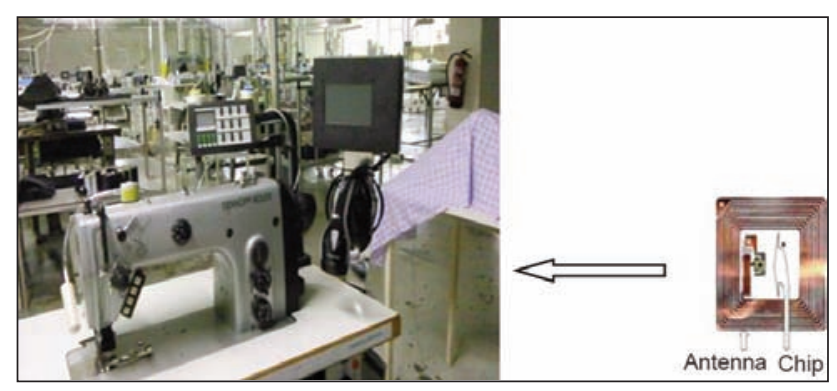

Fig. 4. Sewing machine with barcode scanner and RFID tag

In these circumstances, it is possible a reorganization of workflow and machines, making highly flexible the production and helping the line balancing and allowing small series and short delivery times. In the warehouse, the fabrics reception using RFID technology allows an easier stocks control of quantities of fabrics and accessories, real-time updated, without open the boxes. Also tablets, smart glasses or smart watches are some technologies will help the operators to take the best decisions during the manufacturing process.

\section{CONCLUSIONS}

Industry 4.0 is still in the early stages of implementation in fashion industry (textile, apparel and footwear) and scientific research. The introduction of the "FLUXOCONF" production monitoring program (software from FLUXODATA) was decisive for the evaluation of the technologies to be applied in GUIMA's production system. Being a standard application and an in-house ICT solution, the improvements to be introduced will contribute to the processes becoming flexible and easily reformulated. "FLUXOMES", being an in-house Manufacturing Execution System (MES) software, will make the connection between SOMELOS TECIDOS (fabrics supplier) and GUIMA as well. 
In order to adapt the theories and models known from 14.0 to GUIMA's reality, as RFID in the fabrics and accessories to allow real-time updates of the stocks, all the planning is done with the loS system, the cutting plans and production orders are assisted by a 3D system, the different batches incorporating RFID tags is allowing to get an interaction with the machines that will produce them in the workflow. CPS will connect the mechanical and electronic components to the ICT network, making the processes more flexible. Furthermore, CPS incorporated in the machines will evaluate the real-time production of equipment, allowing to schedule its maintenance and achieving a zero default situation. Finally, it will be easier improving and tuning the processes to the customization of the fashion products, as are nowadays the demands from new consumers.

\section{ACKNOWLEDGEMENTS}

"This work is financed by FEDER funds through the Competitivity Factors Operational Programme - COMPETE and by national funds through FCT - Foundation for Science and Technology within the scope of the project POCI-01-0145-FEDER-007136".

\section{BIBLIOGRAPHY}

[1] Ustundag, A., Cevikcan, E., Industry 4.0: Managing the Digital Transformation, Springer, Switzerland, 2018

[2] European Commission, Digital Economy and Society Index 2016 - Portugal, Available from https://ec.europa.eu/ digital-single-market/en/scoreboard/portugal, 2017, Accessed: 2018-05-02

[3] ATP, Estatísticas da ITV 2016, Edições da ATP, Porto, 2017

[4] Wang, S., Wan, J., Zhang, D., Li, D., Zhang, C., Towards smart factory for industry 4.0: a self-organized multi-agent system with big data based feedback and coordination, In: Computer Networks, 2016, 101, pp. 158-168

[5] Asalos, N., lordanescu, M., The contribution of clusters to increase the competitiveness of the textile and clothing industry. Cluster analysis using location quotient method, In: Industria Textila, 2015, 66, 6, pp. 370-379

[6] Yin, R. K., Case study research: Design and Methods, SAGE publications, Thousand Oaks, 2009

[7] Simons, H., Case study research in practice, SAGE publications, London, 2009

[8] Zhuang, C., Liu, J., Xiong, H., Digital twin-based smart production management and control framework for the complex product assembly shop-floor, In: The International Journal of Advanced Manufacturing Technology, Springer, 2018, 96, Issue 1-4, pp. 1149-1163

[9] ETP - European Technology Platform, Towards a 4th Industrial Revolution of Textiles and Clothing, Public Version Report, Textile ETP, Brussels, 2016

[10] Vilumsone-Nemes, I., Automation in spreading and cutting, In: Automation in Garment Manufacturing, Elsevier Woodhead Publishing, Duxford, 2018, pp. 139-163

[11] Roblek, V., Mesko, M., Krapez, A., A complex view of Industry 4.0, SAGE Open, 2016. pp. 1-11

[12] Jiang, J., An improved cyber-physical systems architecture for Industry 4.0 smart factories, In: Advances in Mechanical Engineering, 2018, 10, Issue 6, pp. 1-15

[13] Lee, J., Bagheri, B., Kao, H., A cyber-physical system architecture for Industry 4.0-based manufacturing systems, In: Manufacturing Letters, 2015, 3, pp. 18-23

\section{Authors:}

\section{HA LUU1 1 , FERNANDO FERREIRA², ANTÓNIO MARQUES ${ }^{2}$}

${ }^{1}$ Industrial University of Ho Chi Minh City, Faculty of Garment Technology and Fashion Design, No. 12 Nguyen Van Bao, Ward 4, Go Vap district, Ho Chi Minh City, Vietnam e-mail: haluusgn@gmail.com

2University of Minho, School of Engineering, Textile Department, Campus de Azurém, 4800-058, Guimarães, Portugal

e-mail: adinis@det.uminho.pt

Corresponding author:

ANTÓNIO DINIS MARQUES

e-mail: adinis@det.uminho.pt 


\title{
The importance of the Dacron cuffs in peritoneal dialysis catheters for acute kidney injury applied in veterinary medicine
}

\author{
DOI: $10.35530 / I T .070 .04 .1685$
}

BOGDAN ALEXANDRU VIȚĂLARU

ALEXANDRA GABRIELA ENE

LAURENTIIU ALEXANDRU CHIOTOROIU

\section{REZUMAT - ABSTRACT}

Importanța manșetelor de Dacron în cateterele pentru dializă peritoneală pentru leziunile renale acute din medicina veterinară

Dializa peritoneală este o tehnică recomandată la pacienții care prezintă uremie nonanurică acută atunci când azotul uremic din sânge (BUN) atinge niveluri de peste $100 \mathrm{mg} / \mathrm{dl}$ sau când creatinina este mai mare de $10 \mathrm{mg} / \mathrm{dl}$. Cateterele pentru dializă acută sunt plasate percutanat, sub anestezie locală, iar cateterele concepute pentru dializă peritoneală cronică au două manșete de Dacron și sunt plasate sub anestezie generală. În acest studiu am selectat 24 de câini, atât masculi, cât și femele cu vârsta cuprinsă între doi și 14 ani, cu ARA, care au făcut dializă peritoneală între 14 zile și 29 de zile. S-au creat două grupuri de pacienți: grupul (A) cu pacienți tratați utilizând un cateter normal peritoneal pentru tratament acut, fără manșete de Dacron și cel de-al doilea grup (B) cu pacienți tratați folosind un cateter peritoneal pentru tratamentul cronic, cu două manșete de Dacron. $75 \%$ dintre pacienții din primul grup au prezentat acumulare de soluție de dializat la nivel subcutanat, ceea ce arată că manșetele Dacron sunt foarte eficiente în prevenirea scurgerii lichidului peritoneal sub piele. Omentectomia este recomandată datorită riscului ridicat de blocare a cateterului de către omentum, dar se recomandă efectuarea acesteia în condiții de maximă siguranță, în ceea ce privește condițiile de asepsie și antisepsie. Peritonita este o complicație majoră a dializei peritoneale, 33.33\% din primul grup, prezentând această complicație și doar $8.33 \%$ din al doilea grup.

Cuvinte-cheie: peritoneal, dializă, cateter, Dacron, manșete, veterinar

The importance of the Dacron cuffs in peritoneal dialysis catheters for acute kidney injury applied in veterinary medicine

Peritoneal dialysis is a technique indicated in patients showing acute nonanuric uremia, when blood urea nitrogen (BUN) reaches levels over $100 \mathrm{mg} / \mathrm{dl}$ or when creatinine is higher than $10 \mathrm{mg} / \mathrm{dl}$. Catheters for acute dialysis are placed percutaneously, under local anaesthesia and catheters designed for chronic peritoneal dialysis have two Dacron cuffs and are placed under general anaesthesia. In this study we have selected 24 dogs, both males and females with age between two and 14 years old, with AKI, undergoing peritoneal dialysis between 14 days and 29 days. We have created two groups of patients: group (A) treated using a normal peritoneal catheter for acute treatment, without Dacron cuffs and the second group $(B)$ treated using a peritoneal catheter for chronic treatment, with two Dacron cuffs. $75 \%$ of patients from the first group were found with accumulation of the dialysate solution at the subcutaneous level, which shows that Dacron cuffs are very efficient in preventing the peritoneal fluid to leak under the skin. Surgical omentectomy is strongly recommended due to the high risk of catheter blockage by the omentum, but it is recommended to be performed under maximum safety with regard to asepsis and antisepsis conditions. Peritonitis is a very important complication of the peritoneal dialysis technique, 33.33\% from the first group, presenting this complication, and only 8.33\% form the second group having it.

Keywords: peritoneal, dialysis, catheter, Dacron, cuffs, veterinary

\section{INTRODUCTION}

The first and foremost indication for peritoneal dialysis in dogs and cats is anuria generated by an acute kidney injury (AKI) that is unresponsive to fluid therapy. Dialysis is also indicated in patients showing acute nonanuric uremia, when blood urea nitrogen (BUN) reaches levels over $100 \mathrm{mg} / \mathrm{dl}$ or when creatinine is higher than $10 \mathrm{mg} / \mathrm{dl}$ [1].

Peritoneal dialysis is contraindicated in patients with peritoneal adhesions, fibrosis or abdominal malignant tumors [1].
The ideal catheter for dialysis allows for an adequate administration and evacuation of the dialysate, it determines minimum subcutaneous losses, it minimizes infection both in the peritoneal cavity and in the subcutaneous tissue [2].

Catheters for acute dialysis are placed percutaneously, under local anaesthesia, with the help of a stiletto and they require immediate heparinization. These catheters are usually straight with orifices at the distal end. Acute catheters generally do not have Dacron cuffs in order to protect the patient against bacterial infection and catheter migration, that may 
lead to a high peritonitis rate in case of extensive use [3].

Catheters for chronic peritoneal dialysis have specific models, both intraperitoneal and extraperitoneal, in order to reduce secondary effects and to minimize blockage. These catheters are made of silicon, rubber or polyurethane [3].

Catheters designed for chronic peritoneal dialysis have Dacron cuffs meant to protect the patient against bacterial infection and catheter migration that may lead to a high peritonitis rate in case of extensive use [2].

The intraperitoneal segment of catheters has numerous lateral orifices at the distal end that allow the free flow of dialysate. The distal end of the peritoneal dialysis catheter may be straight or coiled. The coiled end may help with avoiding blockage. The segment of the catheter that comes out of the abdomen usually presents one or two Dacron cuffs. The Dacron cuffs generate a local inflammatory response that triggers the emergence of granulation or fibrous tissue. This tissue fixes in place the catheter and it prevents the migration of bacteria from skin to the peritoneal cavity [4].

There are no studies performed in veterinary medicine meant to assess the practicality of a certain type of catheter for peritoneal dialysis [5].

In cases of extreme emergency, when the peritoneal dialysis should not be used more than 72 hours, the placement of a short term catheter is justified [6-7].

When placing a peritoneal dialysis catheter, which is meant to be used for more than three days, it is recommended to use a permanent catheter. The longterm peritoneal dialysis catheter should be surgically placed. The surgical placement of the catheter allows the visualization of the abdominal cavity and it is useful in omentectomy. Surgical omentectomy is also recommended due to the high risk of catheter blockage by the omentum [7-8].

Afterwards, it is possible to take the final step, placing the long term peritoneal dialysis catheter [2].

Once surgically placed, in human medicine, peritoneal dialysis catheters should be used after at least 10 to 14 days. This period of time allows for wound healing, scar formation around the Dacron cuffs and minimization of dialysate leakage around the penetration site of the catheter. For obvious reasons, in veterinary medicine, peritoneal dialysis requires the immediate use of the peritoneal catheters, since most of the cases are major emergencies and they cannot be postponed for such a duration of time [2].

Polyethylene terephthalate forms the basis for synthetic fibres like Dacron, Terylene and polyester. Polyester is a category of polymers that contain the ester functional group in their main chain. As a specific material, it most commonly refers to a type called polyethylene terephthalate [7-8].

In this study, we have tested peritoneal catheters with Dacron cuffs and peritoneal catheters without Dacron cuffs.

\section{MATERIALS AND METHODS}

In this study we have selected 24 dogs, both males and females with $\mathrm{AKI}$ undergoing peritoneal dialysis. The study started in January 2014 and finished in December 2018. All patients were tested for other associated pathologies and none of the selected patients presented other morbidities of infections of the peritoneal cavity or at the skin, around the catheter placement area.

The patients' age has two to 14 years old and the longest period that they were submitted to peritoneal dialysis has 29 days. The shortest period of treatment was 14 days.

The diseases that were treated were: acute intoxication with ethylene glycol, babesiosis, raisin intoxication, acute obstruction of the urethra, urinary bladder rupture.

We have created two groups of patients: first group (A) of 12 patients were treated using a normal peritoneal catheter for acute treatment, without Dacron cuffs and the second group of 12 patients $(B)$ were treated using a peritoneal catheter for chronic treatment, with two Dacron cuffs.

In the first group, the peritoneal catheter was placed percutaneously, under local anaesthesia, with the help of a stiletto and they required immediate heparinization. The catheters were fixed in place by suturing the skin with a non-absorbable monofilament thread ranging from $4 / 0$ to $2 / 0$.

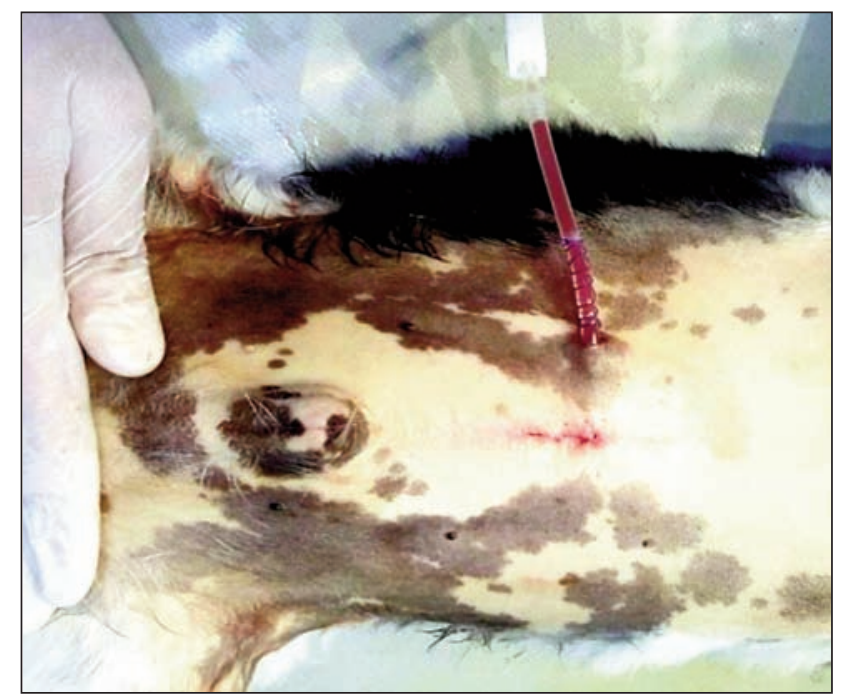

Fig. 1. Roman sandal suture for the temporary peritoneal catheter in dogs with $\mathrm{AKI}$ (orig.)

The patients from the second group needed general anaesthesia and the catheters were placed using a surgical technique. The surgical placement of the catheter allowed the visualization of the abdominal cavity and it is useful in omentectomy. Surgical omentectomy was also recommended due to the high risk of catheter blockage by the omentum [9]. Peritoneal dialysis catheters were trimmed (cut), resizing them at the desired level for entering the peritoneal cavity, in order to reach the bottom of the Douglas pouch. 
The catheters were pre-measured and, after being cut, they were inserted into the cavity. The abdominal muscles were sutured using an absorbable monofilament thread and the last suture, or a separate suture point, was anchored in the distal Dacron cuff of the peritoneal catheter. Subsequently, the anterior end of the catheter was passed through a subcutaneous lateral tunnel and it was exteriorized through the skin at 3-5 cm from the main incision line, so that the second Dacron cuff was located at subcutaneous level. We used Roman sandal technique in all patients as the safest and easiest method to place and maintain sutures in the case of a peritoneal dialysis catheter.

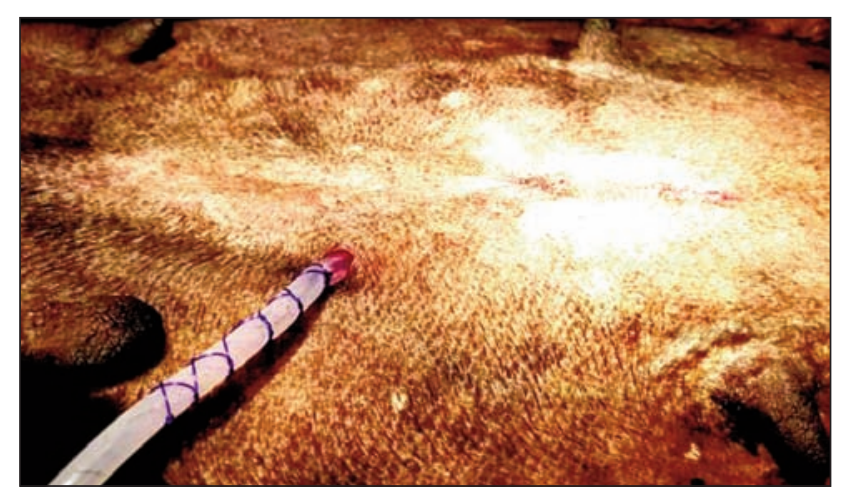

Fig. 2. Roman sandal suture for the permanent peritoneal catheter in dogs with AKI (orig.)

\section{RESULTS AND DISCUSSIONS}

After analysing all the data form the patient undergoing peritoneal dialysis, we have reached important data. All cases were successfully, none of the patients died and all of the patients recovered fully after the treatment, without presenting any kidney impairment according to the IRIS scale.

The patients from the first group, having placed temporary dialysis catheters were found with accumulation of the dialysate solution at the subcutaneous level. This happened in 9 form 12 cases (75\%). None of the patients from the second group, having placed permanent dialysis catheters were found with accumulation of the dialysate solution at the subcutaneous level.

Peritoneal catheter obstruction was found in 11 form 12 patients $(91.66 \%)$ from the first group having

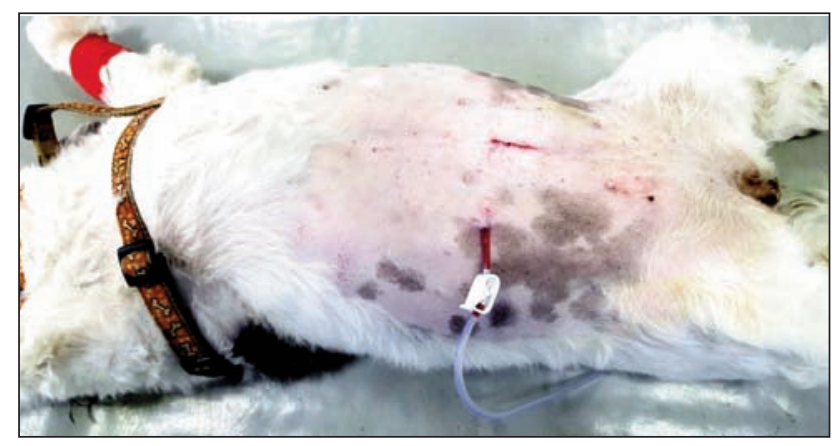

Fig. 3. Accumulation of the dialysate solution at the subcutaneous level in dogs with AKI (orig.) placed temporary dialysis catheters, because all these patients had the omentum in place and dialysis solution retention (the recovery of less than $90 \%$ of the dialysate solution) represented a very common finding. None of the patients from the second group, having placed permanent dialysis catheters had problems in peritoneal dialysis fluid recovery.

Peritonitis was diagnosed in four out of 12 patients (33.33\%) from the first group, having placed temporary dialysis catheters. Peritonitis was considered when two of the three following criteria are identified: turbid dialysate fluid when extracted, extracted dialysate fluid with more than 100 inflammatory cells/ $\mu \mathrm{L}$, or a positive bacterial culture test in the extracted dialysate solution, and clinical symptomatology characteristic of peritonitis. The dialysate solution was contaminated with Escherichia coli, Klebsiella or Enterococcus. Just one of the 12 patients (8.33\%) from the second group, having placed permanent dialysis catheters was found with peritonitis and the fluid culture showed Escherichia coli infection.

The only disadvantage of the technique for placing the permanent dialysis catheters is a longer working duration for the procedure, higher costs, and a longer incision for the catheter placement.

Table 1

\begin{tabular}{|l|c|c|c|c|}
\hline \multicolumn{3}{|c|}{ RESULTS OBTAINED AFTER ANALYSING ALL THE } \\
DATA FROM THE PATIENTS IN THE TWO GROUPS \\
\hline \multicolumn{1}{|c|}{ Results } & \multicolumn{2}{|c|}{ GROUP A } & \multicolumn{2}{c|}{ GROUP B } \\
\cline { 2 - 5 } & Number & Percent \% & Number & Percent \% \\
\hline $\begin{array}{l}\text { Sc fluid } \\
\text { accumulation }\end{array}$ & 9 & 75 & 0 & 0 \\
\hline $\begin{array}{l}\text { Peritoneal } \\
\text { catheter } \\
\text { obstruction }\end{array}$ & 11 & 91.66 & 0 & 0 \\
\hline Peritonitis & 4 & 33.33 & 1 & 8.33 \\
\hline
\end{tabular}

\section{CONCLUSIONS}

Using a permanent dialysis catheters needs a longer working duration for the procedure, with higher costs, and a longer incision for the catheter placement, but with less risks.

In our study, $75 \%$ of patients from the first group, having placed temporary dialysis catheters were found with accumulation of the dialysate solution at the subcutaneous level, which shows that Dacron cuffs are very efficient in preventing the peritoneal fluid to leak under the skin.

Surgical omentectomy is strongly recommended due to the high risk of catheter blockage by the omentum, but it is recommended to be performed under maximum safety with regard to asepsis and antisepsis conditions.

Peritonitis is a very important complication of the peritoneal dialysis technique, $33.33 \%$ from the first group, having placed temporary dialysis catheters presenting this complication, and only $8.33 \%$ form the second group having it. 


\section{BIBLIOGRAPHY}

[1] Acierno, M.J., Labato, Mary, Kidney Diseases and Renal Replacement Therapies, An Issue of Veterinary Clinics: Small Animal Practice, Elsevier-Saunders, Ottawa, 2011

[2] Vițălaru, A.B, Ștefănescu, Alina, Peritoneal Dialysis in small animals, Ed. Printech, București, 2018

[3] McQuiston, Jennifer H., Ehrlichiosis and Related Infections, The Merck Veterinary Manual, 2014

[4] Stokes, J.E., Bartges, J.W., Causes of acute renal failure, Compend Contin Educ Pract Vet, 2006

[5] Stojimirovici, B., Trbojevic-Stankovic, J., Animal models in peritoneal dyalisis, In: Scand. J. La. Anim. Sci., 2007, 34, 4

[6] Thornhill J.A., Peritoneal dialysis in the dog and cat: an update, In: Compend Cortin Educ Prac Vet, 1981, 3, pp. 20-34

[7] Thornhill, J.A., Peritonitis associated with peritoneal dialysis: diagnosis and treatment, In: J Am Vet Assoc., 1983, 182, p. 721

[8] Kushwaha, R., Singh, N., Peritoneal dialysis in animals - A review, In: The Internet Journal of Veterinary Medicine, 2008, 7, 12008

[9] Vasileacu, D., Ionita, S., Grama, V., Pelinaru, A., Chiotoroiu, A., Alloplastic parieto-synthesis complications in abdominal wall reconstructivesurgery - our clinical experience, In: Industria Textila, 2018, 69, 2, pp. 133-140

\section{Authors:}

\section{BOGDAN ALEXANDRU VIȚĂLARU ${ }^{1}$, ALEXANDRA GABRIELA ENE²,}

\section{LAURENTIU ALEXANDRU CHIOTOROIU ${ }^{3}$}

${ }^{1}$ University of Agricultural Sciences and Veterinary Medicine Bucharest, Faculty of Veterinary Medicine Bucharest, Department of Clinical Sciences, Splaiul Independenței, 105, Bucharest, e-mail: alexandrumv@yahoo.com

${ }^{2}$ The National Research and Development Institute for Textiles sand Leather, IT Research Department in Industrial Engineering, Department, 030508, Bucharest, Romania e-mail: alexandra.ene@certex.ro

${ }^{3}$ General Surgery - Emergency Hospital Bucharest Romanaia e-mail: chiotoroiu@yahoo.com

Corresponding author: BOGDAN ALEXANDRU VIȚĂLARU e-mail: alexandrumv@yahoo.com 


\title{
Quality optimization of ring spun yarns produced from blends of regenerated cellulosic fibres with cotton and polyester
}

\author{
DOI: $10.35530 / I T .070 .04 .1630$
}

ESIN SARIOĞLU

\section{REZUMAT - ABSTRACT}

Optimizarea calității firelor filate cu inele produse din fibre celulozice regenerate în amestec cu fibre de bumbac și de poliester

Fibrele celulozice regenerate sunt utilizate în principal în amestecurile de bumbac și poliester cu diferite proporții, pe diferite sisteme de filare, pentru a satisface cerințele specifice ale consumatorilor din industria textilă. Acest studiu realizează o analiză a proprietăților și optimizarea calității firelor filate cu inele, cu fineţea de 19,7 tex, din fibre celulozice regenerate Viloft $\circledast$, ProModal® și bambus în amestec cu fibre de poliester și de bumbac în proporție diferită (100\%, $67-33 \%, 50-50 \%, 33-67 \%)$. Proprietățile firelor, cum ar fi rezistența la tracțiune și alungirea, neuniformitatea, imperfecțiunile și pilozitatea au fost evaluate și comparate pentru a determina influenţa tipului de amestec, tipului de fibră și raportului de amestec. Mai mult, metoda de optimizare numerică a fost dezvoltată pentru a estima parametrii optimi ai calității firelor pentru cele mai bune variabile de răspuns ale următoarelor proprietăți: rezistența la tracțiune și alungirea, neuniformitatea, imperfecțiunile și pilozitatea.

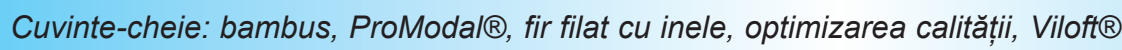

Quality optimization of ring spun yarns produced from blends of regenerated cellulosic fibres with cotton and polyester

Regenerated cellulosic fibres are mainly used with the blends of cotton and polyester with different proportion on different spinning systems to meet specific consumer demands in textile industry. This study conducts the properties and quality optimization of 19.7 tex ring spun yarns made from Viloft ${ }^{\circledR}$, ProModa ${ }^{\circledR}$ and Bamboo regenerated cellulosic fibres blended with polyester and cotton at different proportion (100\%, 67-33\%, 50-50\%, 33-67\%). Yarn properties such as tensile strength and elongation, unevenness, imperfection index and hairiness were evaluated and compared to determine the effects of blend type, fibre type and blend ratio. Furthermore, numerical optimization method was developed to estimate optimum yarn quality parameters for the best response variables of tensile strength and elongation, unevenness, imperfection index and hairiness properties.

Keywords: Bamboo, ProModa ${ }^{\circledR}$, ring spun yarn, quality optimization, Viloft $^{\circledR}$

\section{INTRODUCTION}

To respond consumer demands in textile industry, producers have been focused on acceptable quality and cost of producing yarns. Blending of different fibres is a very common practice to improve better characteristics of fabrics such as drape properties, comfort ability, durability, dyeability, etc. [1-2]. Many researchers have been concerning about blending of different kinds of fibres, proportion and blended yarn characteristics produced on different spinning systems that is ring, open-end, air-jet, friction and vortex. Blending of different kinds of fibres is widely used to reveal new alternative functional products and to improve the performance and the aesthetic qualities of yarns and fabrics [2]. Approximation of physical and mechanical properties of blended yarns has also been studied by various researchers [3-8].

There are various regenerated cellulosic fibre alternatives to enhance the performance of yarn and fabrics. Kilic et al. [9] compared the structural, physical and mechanical properties of cotton-Tencel and cotton-ProModal ${ }^{\circledR}$ blended ring, compact and vortex spun yarns with different blend ratios. They stated that the effect of spinning system is statistically significant on yarn unevenness, imperfections, diameter, density, roughness and roundness, except neps of yarn. By increasing presence of regenerated cellulosic fibre content, it was found that unevenness, imperfections, diameter and roughness values decreased whereas tenacity, elongation, density and shape values increased. When considering the materials used, cotton-ProModal ${ }^{\circledR}$ blended yarns had better structural and physical properties than cottonTencel ${ }^{\circledR}$ blended yarns; however, these yarns had lower mechanical properties. Demiryürek et al. [10] investigated the thermal properties such as thermal conductivity, thermal diffusivity, thermal absorptivity, thermal resistance, moisture, and also air permeability of $\mathrm{Viloft}^{\circledR}$-cotton and $\mathrm{Viloft}^{\circledR}$-polyester single- jersey and $1 \times 1$ rib knitted fabrics. It was found that fabrics made from higher proportion of $\mathrm{Viloft}^{\circledR}$ fibres having flat cross-section and crenulated surface improved thermal characteristics. On the other hand, because of its flat cross-section that tends to protrude the fibres from main body of the yarn, higher Viloft ${ }^{\circledR}$ content in the yarn showed higher hairiness property 
[11]. Atasagun et al. analyzed physical, mechanical and transfer properties of $1 \times 1$ rib fabrics made by blending Viloft ${ }^{\circledR}$ fibre, natural, synthetic, and functional fibres [12]. As also understood from the studies above, regenerated cellulosic fibres were blended with especially cotton and polyester which are commonly used commercially to evaluate the performance of yarns and fabrics by changing raw materials, blend ratios, yarn count, yarn spinning systems etc. North compared the comfort and fabric performance of single-jersey fabrics containing Viloft ${ }^{\circledR}$ fibres that is in $100 \%$, in blends with cotton, in blends with viscose, in blends with Modal and with other cellulosic fibres [13]. He concluded that fabrics containing $100 \%$ Viloft $^{\circledR}$ fibres obtain the highest wearer comfort rating among the fabrics tested. In addition, fabrics containing Viloft ${ }^{\circledR}$ fibres contributed the thermal insulation and wearer comfort properties, as well. Viloft ${ }^{\circledR}$ fibre is mainly used with blends of polyester and cotton in the market and naturally soft and guarantee outstanding wearer comfort. The specialty of $\mathrm{Viloft}^{\circledR}$ has exceptional properties due to its special unique flat cross-section with a crenellated surface. Yarns made of Viloft ${ }^{\circledR}$ contain up to $70 \%$ air gap and fabrics using Viloft ${ }^{\circledR}$ feel soft and light as a feather on the skin and these fibres are of $100 \%$ natural origin and are manufactured from renewable materials. They are also $100 \%$ biodegradable and so they complete the natural cycle [14]. ProModal ${ }^{\circledR}$ consists of a blend of Modal ${ }^{\circledR}$ and Tencel ${ }^{\circledR}$ fibres that combines Modal's soft hand with Tencel's moisture absorption, skin-sensitive properties and strength [15]. Fabrics rich of ProModal ${ }^{\circledR}$ are used for activewear, casualwear, intimate apparel and home textiles [16]. In addition to these fiber types bamboo fibre is also a kind of regenerated cellulosic fibre made from bamboo pulp. Bamboo can be spun alone or with the blend of other fibres such as rayon, cotton, wool, silk, modal, etc. with regard to the required quality of the products [3-7]. Bamboo fibre contributes the tenacity, thermal conductivity, resistivity to bacteria and high water and perspiration adsorption of textile products [17].

In the light of the previous studies, in this study, quality parameters such as tensile strength and elongation, unevenness, imperfection index (IPI) and hairiness properties of cotton and polyester yarns blended with regenerated cellulosic fibres at different proportions were investigated statistically at $95 \%$ confidence interval. In contrast to earlier research, numerical method was conducted to estimate the quality optimization of these yarns regarding with yarn tensile strength and elongation, unevenness, imperfection index (IPI) and hairiness properties.

\section{EXPERIMENTAL PART}

\section{Material}

In this study, Viloft ${ }^{\circledR}$, ProModal ${ }^{\circledR}$ and bamboo regenerated cellulosic fibres were selected owing to their common and commercial usage. Cotton and polyester fibres were blended with these regenerated cellulosic fibres at three different ratios in order to determine the physical and mechanical properties of ring spun yarns. Meanwhile, pure regenerated cellulosic fibres, polyester and cotton yarns were also manufactured. The physical properties of fibres used in this study are illustrated in table 1. Cotton fibre has 4.5 micronaire value and $30 \mathrm{~mm}$ length. Thus, 19.7 tex $100 \%$ Viloft $^{\circledR}, 100 \%$ ProModal $^{\circledR}$, 100\% Bamboo, 100\% Cotton and $100 \%$ Polyester yarns, polyester/Viloft ${ }^{\circledR}$, polyester/ProModal ${ }^{\circledR}$, Polyester/bamboo, cotton/ Viloft ${ }^{\circledR}$, cotton/ProModal ${ }^{\circledR}$ and cotton/bamboo ring spun yarns, blended in three different proportion (67-33\%, 50-50\% and 33/67\%) were produced.

Table 1

PHYSICAL PROPERTIES OF FIBRES USED IN THE STUDY

\begin{tabular}{|c|c|c|}
\hline Raw material & $\begin{array}{c}\text { Linear density } \\
\text { (dtex) }\end{array}$ & $\begin{array}{c}\text { Staple length } \\
\text { (mm) }\end{array}$ \\
\hline Polyester & 1.3 & 32 \\
\hline Viloft $^{\circledR}$ & 1.9 & 38 \\
\hline Promodal $^{\circledR}$ & 1.3 & 38 \\
\hline Bamboo & 1.5 & 38 \\
\hline
\end{tabular}

Fibers were prepared in the blowroom separately and were blended and processed by three drawing passages in the drawing process in accordance with blend ratios. Eight doublings and eight times drafts were performed in all drawing passages in order to make blends more homogeneous. Roving with 656 tex linear density was used to produce 19.7 tex ring spun yarns at the same production parameters (10000 rpm spindle speed, $\alpha \mathrm{e}=3.7$ ).

\section{Method}

The yarn tests were carried out under standard laboratory conditions $\left(20 \pm 2^{\circ} \mathrm{C}\right.$ and $\left.65 \pm 4 \%\right)$ after the samples had been conditioned for $24 \mathrm{~h}$ [18]. Hairiness, unevenness, imperfections values of yarns were determined by using Uster ${ }^{\circledR}$ Tester 4 at $400 \mathrm{~m} / \mathrm{min}$ test speed all through 2.5 minutes [19]. Uster ${ }^{\circledR}$ Tensorapid device was used to measure tenacity and elongation values at $5 \mathrm{~m} / \mathrm{min}$ test speed and $500 \mathrm{~mm}$ gauge length [20].

The results expressed as means of all assays for polyester and cotton blend were compared separately using 'factorial' analysis in order to determine analysis of variance (ANOVA) by means of Design Expert software version 11 (STAT-EASE Inc., Minneapolis, US) at 0.05 significance level. In addition numerical optimization technique was used for the assessments of desirability approach. Independence levels of parameters were chosen as blend type (Polyester and Cotton), fibre type $\left(\right.$ Viloft $^{\circledR}$, ProModal ${ }^{\circledR}$ and Bamboo) and blend ratio $(100 \%, 67 / 33 \%, 50 / 50 \%$, $33 / 67 \%)$. The process response variables were selected as tenacity, elongation, unevenness, IPI and hairiness which are the most important yarn quality parameters. 


\section{RESULTS AND DISCUSSION}

\section{Tensile strength and elongation properties}

The tenacity graphs of polyester and cotton blended yarns with $\mathrm{Viloft}^{\circledR}$, ProModal ${ }^{\circledR}$ and Bamboo with different blend ratio are illustrated in figure 1 . When polyester blend yarns are taken into consideration, it is easily seen that polyester rich blended yarns have higher tenacity but not for cotton blend yarns. Polyester yarn tenacity is higher than that of pure cotton yarn; it is obvious that synthetic yarn has higher tenacity than natural yarn. It is seen in figure 1, the increasing the regenerated cellulosic fibre content affects the tenacity of blended yarns positively for cotton-ProModal ${ }^{\circledR}$ blended yarns [9]. Among the regenerated cellulosic yarns $100 \%$ ProModal ${ }^{\circledR}$ yarn has the highest tenacity value, while $100 \%$ Viloft $^{\circledR}$ yarn has lowest value. Although Viloft ${ }^{\circledR}$ fibre has highest linear density ( 1.9 dtex) and there are more fibres within the yarn structure, tenacity was obtained as lowest because of the fibre properties. When the effect of the blend ratio changes for cotton-bamboo blended yarns, figure 1 indicates that $100 \%$ bamboo yarn and $100 \%$ cotton yarn has a higher tenacity than blended yarns.

Table 2 shows ANOVA results for response surface 2FI Model for tenacity. It is seen that blend type, fibre type and blend ratio parameters have statistically significant effects on tenacity $(p<0.0001)$ with higher $\mathrm{R}$

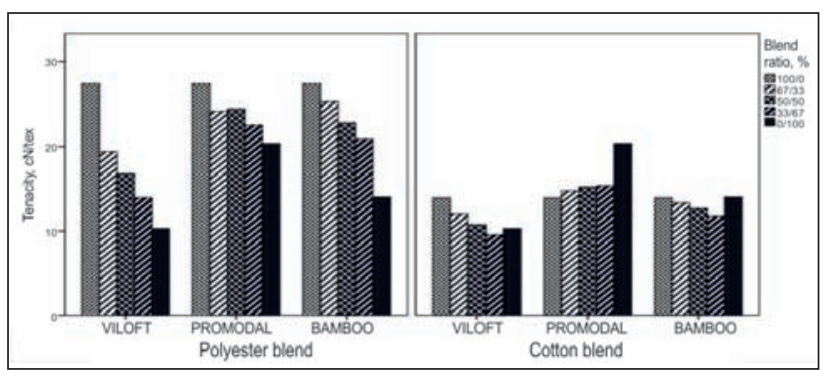

Fig. 1. Tenacity values of blended yarns

Table 2

ANOVA RESULTS FOR RESPONSE SURFACE 2FI
MODEL FOR TENACITY

\begin{tabular}{|l|c|c|c|c|c|}
\hline Source & $\begin{array}{c}\text { Sum of } \\
\text { square }\end{array}$ & DF & $\begin{array}{c}\text { Mean } \\
\text { square }\end{array}$ & F value & $\boldsymbol{p}$-value \\
\hline Model & 921.45 & 9 & 102.38 & 79.66 & $<0.0001$ \\
\hline $\begin{array}{l}\text { A-Blend } \\
\text { Type }\end{array}$ & 446.76 & 1 & 446.76 & 347.61 & $<0.0001$ \\
\hline $\begin{array}{l}\text { B-Fibre } \\
\text { Type }\end{array}$ & 148.10 & 2 & 74.05 & 57.62 & $<0.0001$ \\
\hline $\begin{array}{l}\text { C-Blend } \\
\text { Ratio }\end{array}$ & 117.93 & 1 & 117.93 & 91.76 & $<0.0001$ \\
\hline AB & 9.52 & 2 & 4.76 & 3.70 & 0.0428 \\
\hline AC & 141.08 & 1 & 141.08 & 109.77 & $<0.0001$ \\
\hline BC & 58.06 & 2 & 29.03 & 22.59 & $<0.0001$ \\
\hline Residual & 25.70 & 20 & 1.29 & & \\
\hline Cor Total & 947.16 & 29 & & & \\
\hline
\end{tabular}

industroia textillă

square value of $97 \%$. So it can be said that these all parameters explain the tenacity with the higher $\mathrm{R}$ square. Fibre blend ratio influenced yarn tenacity and this result is expected and reported from some other researchers $[6,9,11,21]$. The most effect size of independent parameters on tenacity is blend type with highest $F$ value.

As regards to fibre type and blend ratio impact on yarn elongation for both polyester and cotton blend types of blended yarns, seen in figure 2, higher yarn elongation could be attained with the addition of a fibre having higher elongation. This situation seems to be true for all cases. Regenerated cellulosic fibre content contributes the breaking elongation of cotton blended yarns positively. They all have higher breaking elongation than that of pure cotton yarn. Pure yarns have a compact structure, thus the elongation increases [11]. A significant increase was observed after $50 \%$ blend ratio for cotton blended yarn. On the other hand, for polyester blend yarns; elongation values do not exhibit regular tendency for all fibre types, however, elongation changes negatively or positively according to the fibre type (ProModal ${ }^{\circledR}<$ Viloff $^{\circledR}<$ Bamboo).

Table 3 illustrates ANOVA results for response surface Quadratic Model for elongation. Blend type has also highest magnitude of effect on yarn elongation

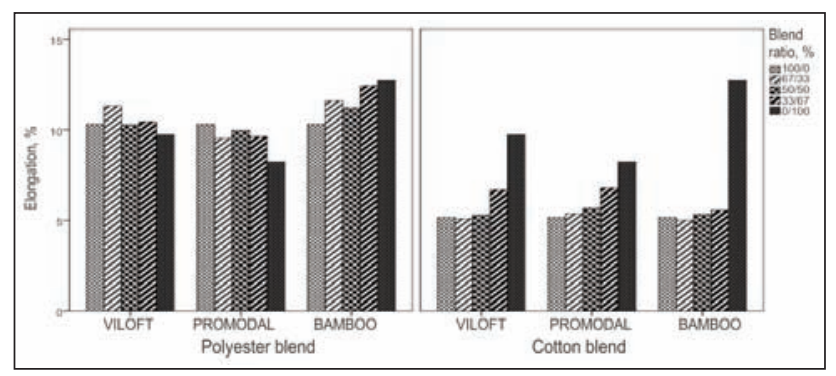

Fig. 2. Elongation values of blended yarns

Table 3

ANOVA RESULTS FOR RESPONSE SURFACE QUADRATIC MODEL FOR ELONGATION

\begin{tabular}{|l|c|c|c|c|r|}
\hline Source & $\begin{array}{c}\text { Sum of } \\
\text { square }\end{array}$ & DF & $\begin{array}{c}\text { Mean } \\
\text { square }\end{array}$ & F value & $\boldsymbol{p}$-value \\
\hline Model & 196.44 & 10 & 19.64 & 22.34 & $<0.0001$ \\
\hline $\begin{array}{l}\text { A-Blend } \\
\text { Type }\end{array}$ & 127.32 & 1 & 127.32 & 144.77 & $<0.0001$ \\
\hline $\begin{array}{l}\text { B-Fibre } \\
\text { Type }\end{array}$ & 9.00 & 2 & 4.5 & 5.12 & 0.0167 \\
\hline $\begin{array}{l}\text { C-Blend } \\
\text { Ratio }\end{array}$ & 16.77 & 1 & 16.77 & 19.07 & 0.0003 \\
\hline$C^{2}$ & 6.94 & 1 & 6.94 & 7.89 & 0.0112 \\
\hline AB & 3.33 & 2 & 1.67 & 1.89 & 0.1779 \\
\hline AC & 23.84 & 1 & 23.84 & 27.11 & $<0.0001$ \\
\hline BC & 9.24 & 2 & 4.62 & 5.25 & 0.0153 \\
\hline Residual & 16.71 & 19 & 0.88 & & \\
\hline Cor Total & 213.16 & 29 & & & \\
\hline
\end{tabular}


with the $\mathrm{F}$ value of 144.77 . All three independent variables have significant effect on elongation with the corresponding $p$ value $<0.05$, however, it was found that the interaction of blend type and fibre type has not statistically significant effect $(p>0.05)$. R squared was determined as higher value of $92 \%$; therefore the quadratic model can be regarded as an appropriate model.

\section{Unevenness}

Yarn evenness can be defined as the variation in weight per unit length of the yarn or as the variation in its thickness. The thickness variation of a yarn is measured by a measuring capacitance and the unevenness is always expressed as between successive lengths and over a total length [22]. Here, $\mathrm{CVm} \%$ value gives a variation of mass for yarns (figure 3). Among some yarns $\mathrm{CVm} \%$ value is the highest for $100 \%$ Viloft $^{\circledR}$ yarn, however, the lowest for 100 $\%$ ProModal $^{\circledR}$ yarn, as the presence of regenerated cellulosic fibre in the yarn structure affects the unevenness and this change is seen obviously for polyester-Viloft ${ }^{\circledR}$ and cotton-Viloft ${ }^{\circledR}$ blended yarns. The increase in unevenness with an increase of Viloft ${ }^{\circledR}$ content is clearly visible. Unevenness in blended yarns depends on fibre length, fibre irregularity, length uniformity etc. in the cross section of the yarn.

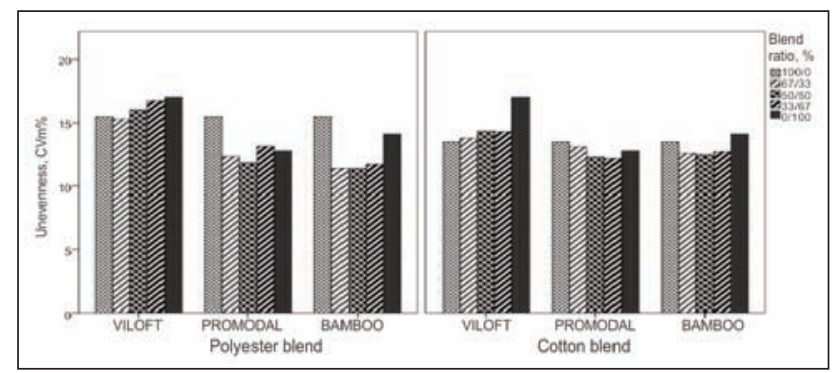

Fig. 3. CVm\% variation of polyester and cotton blended yarns

Table 4

\begin{tabular}{|l|c|c|c|c|c|}
\hline \multicolumn{5}{|c|}{ ANOVA RESULTS FOR RESPONSE QUADRATIC } \\
MODEL OF Cvm\% OF YARNS \\
\hline Source & $\begin{array}{c}\text { Sum of } \\
\text { square }\end{array}$ & DF & $\begin{array}{c}\text { Mean } \\
\text { square }\end{array}$ & F value & $\boldsymbol{p}$-value \\
\hline Model & 66.74 & 10 & 6.67 & 9.58 & $<0.0001$ \\
\hline $\begin{array}{l}\text { A-Blend } \\
\text { Type }\end{array}$ & 2.85 & 1 & 2.85 & 4.09 & 0.0574 \\
\hline $\begin{array}{l}\text { B-Fibre } \\
\text { Type }\end{array}$ & 36.71 & 2 & 18.36 & 26.33 & $<0.0001$ \\
\hline $\begin{array}{l}\text { C-Blend } \\
\text { Ratio }\end{array}$ & 0.30 & 1 & 0.30 & 0.44 & 0.5163 \\
\hline C 2 & 12.13 & 1 & 12.13 & 17.40 & 0.0005 \\
\hline AB & 4.03 & 2 & 2.01 & 2.89 & 0.0802 \\
\hline AC & 1.58 & 1 & 1.58 & 2.26 & 0.1489 \\
\hline BC & 9.14 & 2 & 4.57 & 6.55 & 0.0069 \\
\hline Residual & 13.24 & 19 & 0.70 & & \\
\hline Cor Total & 79.99 & 29 & & & \\
\hline
\end{tabular}

Moreover, Viloft ${ }^{\circledR}$ has an irregular cross section that influences the variations in the cross section of the blended yarn. This is even the same for other ProModal $^{\circledR}$ and bamboo yarns used for this study in different blend ratio with both polyester and cotton.

Table 4 displays the ANOVA results for response Quadratic Model of Cvm\% of yarns. Obtained between $\mathrm{CVm} \%$ and independent variables, blend type and blend ratio do not have statistically significant influence on unevenness with $p>0.05$. It seems that only regenerated cellulosic fibre type has statistically significant effect on Cvm\% of yarn samples. $\mathrm{R}$ squared for Quadratic Model is found to be as $83 \%$.

\section{Imperfection index (IPI)}

The cumulative total of the values of thin places $(-50 \% / \mathrm{km})$, thick places $(+50 \% / \mathrm{km})$ and neps $(+200 \% / \mathrm{km})$ of cotton and polyester blended ring spun yarn samples were determined and the results graphs is given in figure 4. Upon the examination of fibre type $\left(\right.$ Viloft $^{\circledR}$, Promodal ${ }^{\circledR}$ and Bamboo), Viloft ${ }^{\circledR}$ fibre has the highest IPI values for polyester blend than that of the other fibre types. The linear density of Viloft ${ }^{\circledR}$ is 1.9 dtex and due to having a flat cross section and crenulated surface, Viloft ${ }^{\circledR}$ fibre can resist the packing of yarn, it means that imperfection can probably occur in the cross section of the yarn [11]. For the rest of fibre types, Promodal ${ }^{\circledR}$ and Bamboo

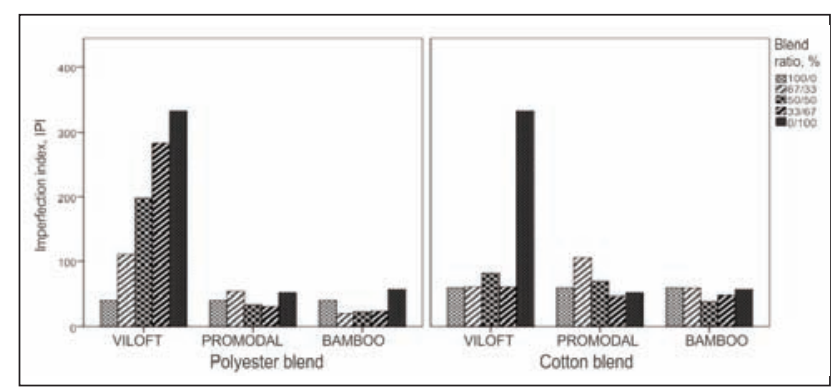

Fig. 4. IPI of polyester and cotton blended yarns

\begin{tabular}{|c|c|c|c|c|c|}
\hline \multicolumn{6}{|c|}{$\begin{array}{c}\text { ANOVA RESULTS FOR RESPONSE 2FI MODEL } \\
\text { FOR IPI OF YARNS }\end{array}$} \\
\hline Source & $\begin{array}{l}\text { Sum of } \\
\text { square }\end{array}$ & DF & $\begin{array}{l}\text { Mean } \\
\text { square }\end{array}$ & \begin{tabular}{|c|}
$F$ \\
value
\end{tabular} & $p$-value \\
\hline Model & $1.762 \mathrm{E}+005$ & 9 & 19575.08 & 9.13 & $<0.0001$ \\
\hline $\begin{array}{l}\text { A-Blend } \\
\text { Type }\end{array}$ & 2851.88 & 1 & 2851.88 & 1.33 & 0.2623 \\
\hline $\begin{array}{l}\text { B-Fibre } \\
\text { Type }\end{array}$ & 71288.49 & 2 & 35644.24 & 16.63 & $<0.0001$ \\
\hline $\begin{array}{l}\text { C-Blend } \\
\text { Ratio }\end{array}$ & 32692.54 & 1 & 32692.54 & 15.25 & 0.0009 \\
\hline $\mathrm{AB}$ & 11960.60 & 2 & 5980.30 & 2.79 & 0.0853 \\
\hline$A C$ & 2496.10 & 1 & 2496.10 & 1.16 & 0.2933 \\
\hline $\mathrm{BC}$ & 54886.15 & 2 & 27443.08 & 12.80 & 0.0003 \\
\hline Residual & 42864.16 & 20 & 2143.21 & & \\
\hline Cor Total & $2.190 \mathrm{E}+005$ & 29 & & & \\
\hline
\end{tabular}


blended yarns show lower and similar IPI values. When the fibre blend parameter is taken into consideration, pure polyester yarn has lower IPI value than that of pure cotton yarns.

As seen in table 5, when the analyzing of factorial design of $2 \mathrm{FI}$ Model ANOVA results, it is found that blend type has not statistically significant effect on IPI value $(p=0.2623)$. Because there is no difference between polyester and cotton blended yarns IPI values at $95 \%$ significance level. On the other hand, fibre type and blend ratio have statistically significant effect on IPI value and R squared for this model was estimated as $80 \%$ as a high value.

\section{Hairiness}

Hairiness values of ring spun blended yarn samples determined with Uster ${ }^{\circledR}$ Tester 4 as Uster $^{\circledR} \mathrm{H}$ value is given in figure 5 . When the increase in the regenerated cellulosic fibre content is considered, hairiness value changes are found to be different according to the fibre type. Similar with IPI values of Viloft ${ }^{\circledR}$ blended polyester ring spun yarns, hairiness value of yarn also increases from lower to higher Viloft ${ }^{\circledR}$ content except $50 \% / 50 \%$ blend ratio. In contrast to Viloft $^{\circledR}$ blended yarns, bamboo rich polyester blended yarns have lower hairiness value than that of pure polyester yarn. This result is seen as similar to cotton-bamboo blended yarns in general. Furthermore, hairiness values of pure ProModal ${ }^{\circledR}$ and pure polyester yarn are seems to be close to each other and the difference is low. On the other hand, it can be said that Promodal ${ }^{\circledR}$ and Bamboo content has decreasing effect on hairiness values of cotton blend ring spun yarns. In addition, pure cotton yarn has higher hairiness than pure polyester yarn because cotton is natural fibre. Because of the circular cross-section of the polyester fibre leads to more compactness thus the number of free ends per unit length of the yarn can reduce.

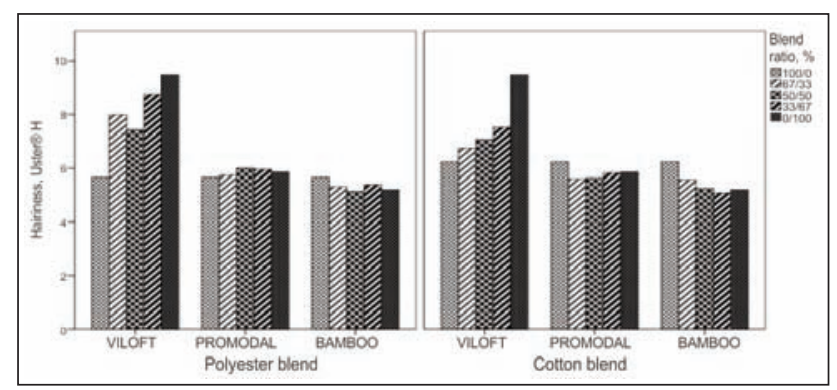

Fig. 5. Hairiness of polyester and cotton blended yarns

2FI model was chosen as suggested model for the ANOVA analysis of the hairiness (table 6). Results show that blend type (polyester and cotton) has not statistically significant effect with $p=0.4158$. On the other hand, fibre type and blend ratio was found to be statistically significant $(p<0.0001)$. The highest effect is obtained with fibre type with the $F$ value of 119.14 . It is probably concluded that $2 \mathrm{FI}$ model can explain the hairiness of yarn samples with the highest value of $95 \% \mathrm{R}$ squared.

\begin{tabular}{|l|c|c|c|c|c|}
\hline \multicolumn{6}{|c|}{ ANOVA RESULTS FOR RESPONSE 2FI MODEL } \\
FOR HAIRINESS OF YARNS \\
\hline Source & $\begin{array}{c}\text { Sum of } \\
\text { square }\end{array}$ & DF & $\begin{array}{c}\text { Mean } \\
\text { square }\end{array}$ & $\begin{array}{c}\text { F } \\
\text { value }\end{array}$ & p-value \\
\hline Model & 45.31 & 9 & 5.03 & 40.75 & $<0.0001$ \\
\hline $\begin{array}{l}\text { A-Blend } \\
\text { Type }\end{array}$ & 0.085 & 1 & 0.085 & 0.69 & 0.4158 \\
\hline $\begin{array}{l}\text { B-Fibre } \\
\text { Type }\end{array}$ & 29.45 & 2 & 14.72 & 119.14 & $<0.0001$ \\
\hline $\begin{array}{l}\text { C-Blend } \\
\text { Ratio }\end{array}$ & 2.99 & 1 & 2.99 & 24.20 & $<0.0001$ \\
\hline AB & 0.48 & 2 & 0.24 & 1.93 & 0.1706 \\
\hline AC & 0.27 & 1 & 0.27 & 2.15 & 0.1581 \\
\hline BC & 12.05 & 2 & 6.02 & 48.76 & $<0.0001$ \\
\hline Residual & 2.47 & 20 & 0.12 & & \\
\hline Cor Total & 47.79 & 29 & & & \\
\hline
\end{tabular}

\section{Quality optimization}

In order to optimize the yarn quality, numerical optimization method was used to find a point that maximizes the desirability function. Desirability is an objective function to the target that ranges from the zero outside of the limits to one at the goal. Desirability method makes use of an objective function, $\mathrm{D}(\mathrm{X})$, called the desirability function. This function reflects the desirable ranges for each response $\left(d_{i}\right)$ and desirable ranges changes from 0 to 1 which corresponds least to most desirable and involves the use of a geometric mean of individual desirability [23-25]. For various responses and factors, all targets are combined as a desirability function. The simultaneous objective function is a geometric mean of all transformed responses which is defined as equation (1) given below.

$$
D=\left(d_{1} \times d_{2} \times \ldots \times d_{n}\right)^{\frac{1}{n}}=\left(\prod_{i=1}^{n} d_{i}\right)^{\frac{1}{n}}
$$

Where $n$ is the number of responses in the measure. If any of the responses or factors fall outside their desirability range, the overall function becomes zero [25]. In determining desirability function, the importance $\left(r_{j}\right)$ of each response which varies from least important $(+)$ to the most important $(+++++)$ can be assigned relative to the other responses. The objective function is estimated as equation (2) if varying degrees of importance are assigned to the different responses.

$$
D=\left(d_{1}^{r_{1}} \times d_{1}^{r_{2}} \times \ldots \times d_{1}^{r_{n}}\right)^{\frac{1}{\sum r_{i}}}=\left(\prod_{i=1}^{n} d_{1}^{r_{i}}\right)^{\frac{1}{\sum r_{i}}}
$$

Where $n$ is the number of responses in the measure. If an individual response is to be maximized, the individual desirability is defined as the following formulas:

$$
\begin{aligned}
& d_{i}=0 \rightarrow Y_{i} \leq \operatorname{Low}_{i} \\
& d_{i}=\left[\frac{Y_{i}-\operatorname{Low}_{i}}{\text { High }_{i}-\operatorname{Low}_{i}}\right]^{w t_{i}} \rightarrow \operatorname{Low}_{i} \leq Y_{i} \leq \operatorname{High}_{i}
\end{aligned}
$$




$$
d_{i}=1 \rightarrow Y_{i} \geq \operatorname{High}_{i}
$$

For goal of minimum, the desirability will be explained by the following formulas:

$$
\begin{aligned}
& d_{i}=1 \rightarrow Y_{i} \leq \text { Low }_{i} \\
& d_{i}=\left[\frac{\text {High }_{i}-Y_{i}}{\text {High }_{i}-\text { Low }_{i}}\right]^{w t_{i}} \rightarrow \operatorname{Low}_{i} \leq Y_{i} \leq \text { High }_{i} \\
& d_{i}=0 \rightarrow Y_{i} \geq \text { High }_{i}
\end{aligned}
$$

The shape of the desirability can be changed in accordance with each goal by the 'weight' field. It should be used weights to give added emphasis to the upper/lower bounds. With a weight of 1 the $d_{i}$ will vary from 0 to 1 in a linear fashion. Weights greater than 1 (maximum weight is 10 ), give more emphasis to the goal. Weights less than 1 (minimum weight is 0.1 ), give less emphasis to the goal [23]. Desirability curves for goal is maximum, minimum and within the range is illustrated in figure 6 .

Before the achieving the numerical optimization of blended ring spun yarns, the constraints of independent parameters (blend type, fibre type and blend ratio) were determined according to the expectation functions/properties from these yarns. The weight of

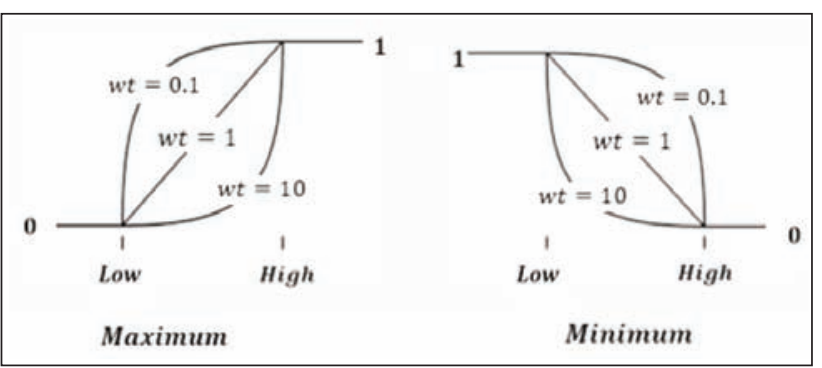

Fig. 6. Desirability curves for goal is maximum or minimum [23]

importance and desired goal of independent variables and response variables are illustrated in table 7. Tenacity and elongation values of the blended yarns were taken as 'Maximize'; on the other hand, $\mathrm{CVm} \%$, IPI and hairiness were taken as 'Minimize'.

The overall desirability values of the multi response numerical optimization results are given in table 8. Here, the desirability represents 'Overall Desirability' including all response variables that the highest overall desirability value is ' 1 ' and the lowest one is ' 0 '.

As clearly seen in table 8 first line (No.1), the highest the value of the overall desirability can be understood as how well the specified goals are achieved and how well all the goals are met [24]. This line clarifies

\begin{tabular}{|l|c|c|c|c|c|c|}
\hline \multicolumn{7}{|c|}{ INDEPENDENT AND RESPONSE VARIABLES } \\
\hline \multicolumn{1}{|c|}{ Name } & Goal & Lower limit & Upper limit & Lower weight & Upper weight & Importance \\
\hline A-Blend Type & Is in range & Polyester & Cotton & 1 & 1 & 3 \\
\hline B-Fibre Type & Is in range & Viloft ${ }^{\circledR}$ & Bamboo & 1 & 1 & 3 \\
\hline C-Blend Ratio & Is in range & 0 & 100 & 1 & 1 & 3 \\
\hline Tenacity, cN/tex & Maximize & 9.562 & 27.431 & 1 & 1 & 5 \\
\hline Elongation, \% & Maximize & 5.013 & 12.718 & 1 & 1 & 3 \\
\hline Unevenness, Cvm\% & Minimize & 11.39 & 17 & 1 & 1 & 5 \\
\hline Imperfection Index, IPI & Minimize & 19.5 & 332.35 & 1 & 1 & 3 \\
\hline Hairiness, Uster ${ }^{\circledR} \mathrm{H}$ & Minimize & 5.08 & 9.7 & 1 & 1 & 5 \\
\hline
\end{tabular}

Table 8

\begin{tabular}{|c|c|c|c|c|c|c|c|c|c|}
\hline \multicolumn{9}{|c|}{ MULTI RESPONSE NUMERICAL OPTIMIZATION RESULTS } \\
\hline No & $\begin{array}{c}\text { A-Blend } \\
\text { Type }\end{array}$ & $\begin{array}{c}\text { B-Fibre } \\
\text { Type }\end{array}$ & $\begin{array}{c}\text { C-Blend } \\
\text { Ratio }\end{array}$ & $\begin{array}{c}\text { Tenacity } \\
\text { (cN/tex) }\end{array}$ & $\begin{array}{c}\text { Elonga- } \\
\text { tion } \\
(\%)\end{array}$ & $\begin{array}{c}\text { Unevenness } \\
\text { Cvm } \\
(\%)\end{array}$ & $\begin{array}{c}\text { Imperfec- } \\
\text { tion Index, } \\
\text { IPI }\end{array}$ & $\begin{array}{c}\text { Hairiness, } \\
\text { Uster }\end{array}$ & Hesirability \\
\hline 1 & Polyester & Bamboo & 73.193 & 25.199 & 11.095 & 12.721 & 24.176 & 5.439 & 0.859 \\
\hline 2 & Polyester & Bamboo & 73.479 & 25.238 & 11.095 & 12.731 & 24.083 & 5.440 & 0.859 \\
\hline 3 & Polyester & Bamboo & 72.561 & 25.115 & 11.094 & 12.698 & 24.381 & 5.436 & 0.859 \\
\hline 4 & Polyester & Bamboo & 71.930 & 25.030 & 11.093 & 12.677 & 24.586 & 5.433 & 0.859 \\
\hline 5 & Polyester & ProModal ${ }^{\circledR}$ & 67.419 & 25.010 & 9.671 & 13.264 & 64.245 & 5.780 & 0.768 \\
\hline 6 & Cotton & ProModal $^{\circledR}$ & 0.0000 & 18.926 & 8.395 & 13.212 & 58.380 & 5.673 & 0.659 \\
\hline 7 & Polyester & Viloft $^{\circledR}$ & 98.236 & 25.747 & 11.300 & 15.902 & 44.882 & 6.039 & 0.601 \\
\hline 8 & Cotton & Bamboo $^{\text {I }}$ & 11.972 & 12.951 & 9.606 & 13.427 & 43.566 & 5.080 & 0.555 \\
\hline 9 & Cotton & Viloft $^{\circledR}$ & 60.321 & 11.719 & 5.503 & 13.691 & 92.899 & 7.112 & 0.302 \\
\hline
\end{tabular}




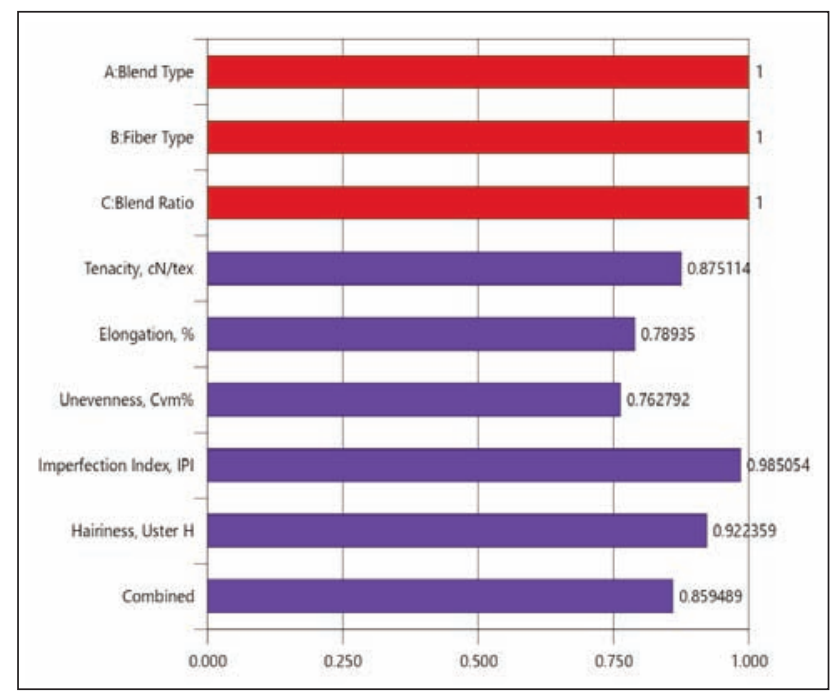

Fig. 7. Individual desirability values of response variables for 0.859 overall desirability

maximum level of tenacity, elongation and minimum level of unevenness, IPI and hairiness which importance of these are predefined in the numerical optimization process. From the line 1, if polyester/ bamboo blended yarn with $73.19 \% / 26.81 \%$ blend ratio is used; overall desirability with the value of 0.859 will meet the goal. It seems as polyester blended regenerated cellulosic fibres are suitable in terms of desired goals, but cotton blended regenerated cellulosic fibres will have lower capability for achieving the goals. Furthermore, table 8 exhibits the optimum blend type, fibre type and blend ratio to attain the desired response variables. Table 8 also exhibits the obtained response variables of tenacity, elongation, unevenness, IPI and hairiness for every desirability value. In that point, the least desirable yarn type was found to be cotton/Viloft ${ }^{\circledR}$ with $60.3 \% / 39.7 \%$ blend ratio at 0.302 desirability value. As clearly seen in the analysis, the desirability of polyester/Viloft ${ }^{\circledR}$ and cotton/Viloft ${ }^{\circledR}$ yarn types are lower than the other regenerated cellulosic fiber types because of Viloft ${ }^{\circledR}$ fiber characteristics which affect the yarn quality directly such as Cvm\% and hairiness. As a conclusion, the best desirability will be obtained from polyester/bamboo blended ring spun yarns with high polyester content. In addition, individual desirability of each response variables can be practiced by means of Design Expert package program. Figure 7 gives the each response variables desirability for the best results of numerical optimization. As seen in figure 7 , the overall desirability is shown as 'Combined' with 0.859 value. Among response variables, the highest desirability is obtained from IPI (0.985). The second highest desirability is determined as hairiness. Desirability of tenacity, elongation and unevenness are found as $0.875,0.789$ and 0.762 , respectively.

\section{CONCLUSION}

The progress in the production of new regenerated cellulosic fibres is growing rapidly.
Especially, regenerated cellulosic fibres are preferred as knitted summer clothes because of their thermal comfort properties and they can be blended at different proportion with natural or synthetic fibres. In this study, Viloft ${ }^{\circledR}$, ProModal $^{\circledR}$ and bamboo regenerated cellulosic fibres were blended with cotton and polyester fiber with different ratios to produce ring spun yarns. Firstly, the tensile strength and elongation, unevenness, IPI and hairiness properties were determined. In addition, the effects of blend type (Polyester and Cotton), fibre type (Vilof ${ }^{\circledR}$, ProModal ${ }^{\circledR}$ and Bamboo) and blend ratio (100\%, 67/33\%, $50 / 50 \%, 33 / 67 \%$ ) parameters on yarn properties were analyzed statistically. Secondly, importance levels of these yarn properties were defined according to the desired goal of response variables in the design in order to achieve numerical optimization of the yarn. Results can be summarized as follows:

- When tensile strength properties of ring spun yarns are taken into consideration, blend type, fiber type and blend ratio have statistically significant effects on tenacity of regenerated/polyester and regenerated/cotton yarns. In addition, the least tenacity value was obtained with pure Viloft ${ }^{\circledR}$ yarn among the other type of regenerated cellulosic fibres. Though regenerated cellulosic fibre content contributes the breaking elongation of cotton blended yarns, for the polyester blend yarns, it was not observed that there is a regular tendency for all regenerated cellulosic fibre type.

- It was found that Viloft ${ }^{\circledR}$ blended yarns had the worst unevenness and IPI values for polyester blend types. Similarly, it is determined that Viloft ${ }^{\circledR}$ blended polyester and cotton yarns had the higher hairiness value.

- In order to determine the best desirability function according to the blend type, fiber type and blend ratio, the importance and levels of the response variables were defined and numerical optimization was achieved. As 'Maximize' function tenacity and elongation were selected because these parameters must be higher during the fabric production and usage stage. On the other hand, unevenness, IP and hairiness which are important features that prevent working comfortably with these yarns in fabric production. And also, these affect the fabric performance and aesthetic properties negatively. So these response variables were taken as 'Minimize' as desired goal. Numerical optimization results show that, for bamboo polyester blended yarn with $73.19 \%$ polyester proportion had the highest desirability (0.859).

\section{ACKNOWLEDGEMENTS}

The authors would like to thank to SANKO Textile Research and Development Center for producing yarn samples and making tensile strength and elongation, unevenness and hairiness measurements. 


\section{BIBLIOGRAPHY}

[1] Majumdar, A., Mukhopadhyay, S., Yadav, R., Mondal, A.K., Properties of ring spun yarns made from cotton and regenerated bamboo fibres, In: Indian Journal of Fibre \& Textile Research, 2011, 36, pp. 18-23

[2] Prakash, C., Ramakrishman, G., Koushik, C.V., Effect of blend ration on quality characteristics of bamboo/cotton blended ring spun yarn, In: Daffodil International University Journal of Science and Technology, 2012, 7, 1, pp. 34-37

[3] Sekerden, F., Investigation on the unevenness, tenacity and elongation properties of bamboo/cotton blended yarns, In: Fibres\&Textiles in Eastern Europe, 2011, 19, 3, pp. 26-29

[4] Demiryürek, O., Kılıç, A., An investigation on the unevenness, hairiness and friction coefficient properties of cottonbamboo blended ring-spun yarns, In: Industria Textila, 2018, 69, 3, pp. 235-242

[5] Malik, S.A., Tanwari, A., Syed, U., Qureshi, R.F., Mengal, N., Blended yarn analysis: Part I - influence of blend ratio and break draft on mass variation, hairiness and physical properties of 15 tex PES/CO blended ring-spun yarn, In: Journal of Natural Fibers, 2012, 9, 3, pp. 197-206

[6] Canoglu, S., Tanir, S.K., Studies on yarn hairiness of polyester/cotton blended ring-spun yarns made of different blend ratios, In: Textile Research Journal, 2009, 79, 3, pp. 235-242

[7] Ahmad, I., Farooq, A., Baig, S.A., Rashid, M.F., Quality parameters analysis of ring spun yarns made from different blends of bamboo and cotton fibres, In: Journal of Quality and Technology Management, 2012, 8, 1, pp. 1-12

[8] Koç, E., Demiryürek, O., Predicting the tensile strength of polyester/viscose blended open-end rotor spun yarns using artificial neural network and statistical models, In: Industria Textila, 2011, 62, 2, pp. 87

[9] Kilic, M., Okur, A., The properties of cotton-Tencel and cotton-Promodal blended yarns spun in different spinning systems, In: Textile Research Journal, 2011, 81, 2, pp. 156-172

[10] Demiryürek, O., Uysaltürk, D., Thermal comfort properties of viloft/cotton and viloft/polyester blended knitted fabrics, In: Textile Research Journal, 2013, 83, 16, pp. 1740-1753

[11] Demiryürek, O., Uysaltürk, D., Statistical analyses and properties of viloft/polyester and viloft/cotton blended ringspun yarns, In: Fibres\&Textiles in Eastern Europe, 2014, 22, 1(103), pp. 22-27

[12] Atasagun, H.G., Öner, E., Okur, A., Beden, A.R., A comprehensive study on the general performance properties of Viloft-blended knitted fabrics, In: The Journal of Textile Institute, 2015, 106, 5, pp. 1-13

[13] North, M., Engineered viscose fibres delivering enhanced wearer comfort and fabric performance, In: Lenzinger Berichte, 2011, 89, pp. 37-42

[14] http://www.kelheim-fibres.com/produkte/vi_te_uk.php, Assessed 11 March 2018

[15] http://www.textileworld.com/Issues/2008/November-December/Knitting-Apparel/Lenzing_Launches_ProModal_ Blended_Fiber, Assessed 03 May 2018

[16] http://www.samil-sp.co.kr/UploadFiles/board/ds0001/1.22213069573E+13001.pdf, Assessed 15 March 2018

[17] Saravan, K., Prakash, C., Bamboo fibres\& their application in textiles, In: The Indian Textile Journal, 2007, 117, pp. 33-36

[18] BS EN ISO 139:2005+A1:2011 Textiles. Standard atmospheres for conditioning and testing

[19] ISO 16549:2004 Textiles. Unevenness of textile strands - Capacitance method

[20] BS EN ISO 2062:2009 Textiles. Yarns from packages. Determination of single-end breaking force and elongation at break using constant rate of extension (CRE) tester

[21] Chattopadhyay, R., Tyagi, G.K., Goyal, A., Studies of the hybrid effect in mechanical properties of tencel blended ring-, rotor-, and air-jet spun yarns, In: The Journal of the Textile Institute, 2013, 104, 3, pp. 339-349

[22] Saville, B.P. Physical testing of textiles, Woodhead Publishing Ltd and CRC Press LLC 1999

[23] Kaynak, H.K. Optimization of stretch and recovery properties of woven stretch fabrics, In: Textile Research Journal, 2017, 87, 5, pp. 582-592

[24] Kaynak, H.K., Babaarslan, O., Duru Baykal, P., Multi-response optimization of thermophysiological comfort properties of polyester filament woven fabrics, In: Journal of Textile Institute, 2017, 108, 10, pp. 1669-1681.

[25] Stat-Ease, www.statease.com. Accessed 05 July 2018

\section{Authors: \\ ESIN SARIOĞLU \\ Gaziantep University}

Faculty of Fine Arts, Department of Fashion and Textile Design

Sehitkamil-27310, Gaziantep, Turkey

e-mail: sarioglu@gantep.edu.tr

Corresponding author:

ESIN SARIOĞLU

e-mail: sarioglu@gantep.edu.tr 


\section{Sensory analysis of textiles: case study of an assortment of stretch denim fabrics}

DOI: $10.35530 / I T .070 .04 .1697$

\section{REZUMAT - ABSTRACT}

\section{Analiza senzorială a produselor textile. Studiu de caz al unui sortiment de țesături denim stretch}

În strategia de a îmbunătăți colecțiile de îmbrăcăminte ca o reacție la schimbările pieței de consum, producătorii de ţesături sunt conștienți de faptul că pe lângă profilul calitativ al țesăturilor este necesară asigurarea unui confort senzorial, care este dependent exclusiv de percepția personală a cumpărătorilor. Acest studiu se referă la evaluarea subiectivă a proprietăților tactile ale unui sortiment de șaptezeci de țesături denim tip stretch, produse din șapte articole create ca bază în faza de țesere. Cu două tipuri de legături diagonal, având fire din bumbac 100\% ca urzeală și, respectiv, șase variante de fire tip bumbac cu componentă de elastan ca bătătură, țesăturile crude au fost supuse la diverse combinații din șase procedee de pre-finisare și patru tehnici de spălare. S-au respectat îndrumările standardelor privind analiza senzorială ca test descriptiv, cu o singură excepție: panelul a fost constituit din șaisprezece evaluatori fără experiență. Analiza statistică a volumului de date a fost efectuată prin instrumentele interactive de învățare, STAT-Hand și STAT-ConCor, dezvoltate anterior studiului. Rezultatele au confirmat diverse modificări ale confortului senzorial al țesăturilor, prin intermediul a șase atribute senzoriale bipolare, evaluate ca descriptori ai acestuia. Deoarece aceste schimbări ale confortului senzorial au fost percepute de către evaluatori naivi, se poate miza pe faptul că și potențialii cumpărători de jeans confecționați din gama sortimentală de denim tip stretch vor putea percepe aceste diferențe, deși sunt evaluatori fără experiență în analiza senzorială. În acest context, țesătorii vor putea miza pe un feedback corect asupra efortului lor de a îmbunătăți permanent confortul senzorial al țesăturilor.

Cuvinte-cheie: evaluatori, analiză senzorială, confort senzorial, denim tip stretch, proprietăți tactile

\section{Sensory analysis of textiles: case study of an assortment of stretch denim fabrics}

The manufacturers, in their strategy to expand the garment collections, as a prompt reaction to the global market changes, are aware that the sensorial comfort is of the utmost importance, next to the quality profile of fabrics, and depends on the personal perception of purchasers. This research focused upon the sensory assessment of the tactile properties of an assortment of seventy stretch denim fabrics produced from seven articles in the loom-state phase. By combining two types of right-hand twill, with $100 \%$ cotton yarns in the warp and six mixture types as core-spun yarns in the weft, the fabrics were subjected to six pre-finishing processes and subsequently, to four washing techniques. The standards' guidelines on conducting the sensory analysis trials as descriptive tests were respected, with one exception: the panel consisted of sixteen assessors without experience. The statistical analysis of the extensive amount of sensory data was approached by the interactive ICT-based learning tools previously developed STAT-Hand and STAT-ConCor. The results showed changes in the six bipolar sensory attributes, as fabric hand descriptors, for the wide range of stretch denim fabrics. Since these changes of the sensorial comfort were perceptible for a panel of naive assessors, the potential stretch denim jeans' purchasers could also notice them. Therefore, this could be a good strategy for denim manufacturers to get the right feedback in their effort to continuously upgrade the fabrics sensorial comfort.

Keywords: assessors, sensory analysis, sensorial comfort, stretch denim, tactile properties

\section{INTRODUCTION}

Considered a specific niche, women's clothing is strongly influenced by trends in colors, pattern and fashion but also by the feelings about an adequate durability, a satisfactory degree of comfort in wearing and finally, yet importantly, a great aesthetic appearance, no matter what is the end use [1-3]. When the garment quality for women is defined from the weaving companies' perspective, there is a focus on the overall features that can be measured in a laboratory [4-5]. Predicting the overall suitability for designed end use and the products' success on the market can be a hard topic for fabrics and clothing manufacturers and for retailers, thus, the improving of the fabric design strategy should be a mandatory task in textile companies [3, 6-8]. A major concern within the textile value chain is to react timely to the consumer preferences and, nowadays, the sensorial comfort of any item of clothing together with the fabric quality seems to come first in the top of the consumer preferences. Regardless of the reference source and the market niche, polls about the clothing consumer lifestyle revealed that when shopping for apparel, consumers are not simply pursuing the latest fashion trends. On the contrary, they are willing to pay more for comfort, general appearance, and high-quality products, more 
than for any other designed features to cover consumers' value expectations [1-3]. This trend was found similar for the denim market, irrespective of segmentation (by product, by consumer type). Moreover, as consumers are becoming more concerned with health and exercise, and both professional and social dress codes are relaxing nowadays, the denim designers and manufacturers realized they needed to compete against athleisure apparel, which has the comfort factor in its side. To support this trend, the jeans manufacturers are innovating and adapting their products by pursuing the consumer demands, including by means of a wide range of finishing techniques carried out in different stages, as pre-finishing and washing processes. In addition, the denim global market landscape essentially changed with the appearance of more comfortable jeans, manufactured from stretch denim fabrics. By default, the stretch denim should have a degree of body fitting and should be more comfortable than the regular denim fabric, even if incorporating a small amount of elastane, and this fact should be proved by means of analysis of the fabrics sensorial comfort features [4-5].

In textiles, the sensory analysis approached as a subjective assessment technique is considered a usual practice for clothing sensorial comfort evaluation, pursuing the upgrading of the design stage for both fabrics and garments [6-10]. Recently, the sensory analysis was applied with good results to assess the comfort of functional fabrics for smart clothing [11]. However, in practice, the sensory analysis of inprocess and finished fabrics should be considered by implementing a sensory analysis programme into quality control [12]. This is because when buying an item of clothing, the consumers (with or without a background in textiles) tend to handle it so they can get a feeling on the fabric's quality and on the sensorial comfort they could benefit from, while wearing the garment [3, 7, 13].

To the best of our knowledge, the sensory analysis of the stretch denim fabrics hand has not yet been addressed. This paper aims to be a contribution to this topic by focusing on the evaluation carried out with a panel of naive assessors, who may be considered as almost untrained customers.

\section{MATERIALS AND METHODS}

\section{Materials}

In this study, a range of stretch denim fabrics, produced on PICANOL OMNI PLUS 800 air jet weaving machines, were chosen for sensory analysis of the tactile properties considering the similarities in manufacturing and final use, as jeans for women. Regarding the percentage of elastane used in the weft yarns, three variants were considered and also, the mixture with polyester next to the elastane asa suitable choice for weaving the stretch denim (table 1). Within the respect of the wide range of possible finishing treatments in denim manufacturing, a variety of pre-finishing treatments were applied in this research for the seven loom-state fabrics and, subsequently, different washing techniques (commonly used in garment industry for washing denim garments). Hence, seventy stretch denim fabrics were produced (half as greige denims and half as finished denims).

Details of the pre-finishing processes applied to the loom-state fabric to obtain the "greige" stretch denim (G01 to G35) are briefly described in table 2. It also describes the washing processes applied in order to obtain an appearance and properties as close as possible to those required by the jeans to be made of these materials, thus achieving the "finished" stretch denim (F01 to F35). Altogether, the labeling of the seventy stretch denim fabrics (greige/finished) was decided in view of the consumers' perception, when they are shopping for jeans.

\section{Techniques for sensory analysis as subjective evaluation of fabric hand}

The evaluation procedure AATCC [14] describes guidelines to assess the tactile properties of textiles by means of human perception of specific sensory attributes, as fabric sensorial comfort descriptors. In addition, approaching the topic of stretch denim fabric hand sensory evaluation, the main requirements on conducting the sensory analysis trials [15-20] showed some particularities in this paper, as follows.

\begin{tabular}{|c|c|c|c|c|c|c|c|c|}
\hline \multicolumn{9}{|c|}{ MAIN FEATURES OF DESIGNED STRETCH DENIM FABRICS IN THE LOOM-STATE PHASE } \\
\hline \multirow{2}{*}{$\begin{array}{l}\text { Article } \\
\text { code }\end{array}$} & \multicolumn{2}{|c|}{ Fabric composition } & \multirow{2}{*}{$\begin{array}{c}\text { Weave } \\
\text { structure }\end{array}$} & \multicolumn{2}{|c|}{$\begin{array}{c}\text { Yarn linear } \\
\text { density (tex) }\end{array}$} & \multicolumn{2}{|c|}{$\begin{array}{l}\text { Thread count } \\
\text { (yarns } / 10 \mathrm{~cm} \text { ) }\end{array}$} & \multirow{2}{*}{$\begin{array}{c}\text { Mass per } \\
\text { unit area } \\
\left(\mathrm{g} / \mathrm{m}^{2}\right)\end{array}$} \\
\hline & Warp & Weft & & Warp & Weft & Ends $/ 10 \mathrm{~cm}$ & Picks $/ 10 \mathrm{~cm}$ & \\
\hline SD1 & $100 \% \mathrm{CO}$ & $99 \% \mathrm{CO} / 1 \% \mathrm{EL}$ & 3/1 twill & 57 & 63 & $265 \pm 10$ & $200 \pm 10$ & $312 \pm 16$ \\
\hline SD2 & $100 \% \mathrm{CO}$ & $98 \% \mathrm{CO} / 2 \% \mathrm{EL}$ & $3 / 1$ twill & 57 & 63 & $270 \pm 10$ & $200 \pm 10$ & $317 \pm 16$ \\
\hline SD3 & $100 \% \mathrm{CO}$ & $98 \% \mathrm{CO} / 2 \% \mathrm{EL}$ & 2/1 twill & 65 & 33 & $257 \pm 10$ & $170 \pm 10$ & $257 \pm 13$ \\
\hline SD4 & $100 \% \mathrm{CO}$ & $92 \% \mathrm{CO} / 8 \% \mathrm{EL}$ & 2/1 twill & 42 & 42 & $250 \pm 10$ & $190 \pm 10$ & $207 \pm 10$ \\
\hline SD5 & $100 \% \mathrm{CO}$ & $92 \% \mathrm{CO} / 7 \% \mathrm{PES} / 1 \% \mathrm{EL}$ & $2 / 1$ twill & 76 & 37 & $240 \pm 10$ & $205 \pm 10$ & $314 \pm 16$ \\
\hline SD6 & $100 \% \mathrm{CO}$ & $85 \% \mathrm{CO} / 13 \% \mathrm{PES} / 2 \% \mathrm{EL}$ & $2 / 1$ twill & 76 & 33 & $220 \pm 10$ & $190 \pm 10$ & $280 \pm 14$ \\
\hline SD7 & $100 \% \mathrm{CO}$ & $77 \%$ CO $/ 22 \%$ PES/1\% EL & $2 / 1$ twill & 33 & 17 & $390 \pm 10$ & $250 \pm 10$ & $198 \pm 10$ \\
\hline
\end{tabular}




\begin{tabular}{|c|c|c|c|c|c|c|}
\hline \multicolumn{7}{|c|}{ PRE-FINISHING AND FINISHING PROCESSES APPLIED TO FABRICS IN LOOM-STATE PHASE } \\
\hline $\begin{array}{c}\text { Stretch } \\
\text { denim } \\
\text { (loom-state) }\end{array}$ & $\begin{array}{c}\text { Industrial } \\
\text { pre-finishing } \\
\text { process }^{*}\end{array}$ & $\begin{array}{l}\text { Greige } \\
\text { fabrics } \\
\text { codes }\end{array}$ & $\begin{array}{l}\text { Expected appearance effects } \\
\text { on fabrics surface }\end{array}$ & $\begin{array}{l}\text { Washing } \\
\text { techniques } \\
\text { (finishing) }\end{array}$ & $\begin{array}{c}\text { Finished } \\
\text { fabrics } \\
\text { codes }\end{array}$ & $\begin{array}{l}\text { Expected } \\
\text { appearance } \\
\text { effects on } \\
\text { fabric surface }\end{array}$ \\
\hline SD1 & \multirow{3}{*}{$\begin{array}{l}\mathrm{B} \rightarrow \mathrm{Si} \rightarrow \mathrm{C} \rightarrow \\
\mathrm{D} \rightarrow \mathrm{Sf} \rightarrow \mathrm{Ac} \rightarrow \\
\mathrm{So} \rightarrow \mathrm{D} \rightarrow \mathrm{Sf}\end{array}$} & G01 & Lustrous surface, leather effect & \multirow{3}{*}{$\begin{array}{l}\text { Light rinse for } \\
\text { coating shine }\end{array}$} & F01 & \multirow{3}{*}{$\begin{array}{l}\text { To protect the } \\
\text { coating and to } \\
\text { give an extra } \\
\text { shine effect }\end{array}$} \\
\hline \multirow{2}{*}{ SD2 } & & G02-G14 & Matt surface effect & & F02-F14 & \\
\hline & & G15-G18 & Semi-lustrous surface effect & & F15-F18 & \\
\hline SD2 & $\begin{array}{l}\mathrm{B} \rightarrow \mathrm{Si} \rightarrow \mathrm{C} \rightarrow \\
\mathrm{D} \rightarrow \mathrm{Sf} \rightarrow \mathrm{Rt} \rightarrow \\
\mathrm{So} \rightarrow \mathrm{D} \rightarrow \mathrm{Sf}\end{array}$ & G19-G21 & $\begin{array}{l}\text { Anti-crease and soft surface } \\
\text { effect }\end{array}$ & \multirow{2}{*}{$\begin{array}{l}\text { Enzyme } \\
\text { washing to } \\
\text { imitate stone } \\
\text { washing }\end{array}$} & F19-F21 & \multirow{2}{*}{$\begin{array}{l}\text { To achieve a } \\
\text { lightly worn and } \\
\text { faded look }\end{array}$} \\
\hline $\begin{array}{l}\text { SD2 } \\
\text { SD4 }\end{array}$ & $\begin{array}{l}\mathrm{B} \rightarrow \mathrm{Si} \rightarrow \mathrm{C} \rightarrow \\
\mathrm{D} \rightarrow \mathrm{Sf}\end{array}$ & $\begin{array}{l}\text { G22-23; } \\
\text { G28-29 }\end{array}$ & $\begin{array}{l}\text { Shinier look, a fuller appear- } \\
\text { ance and a more intense and } \\
\text { regular shade }\end{array}$ & & $\begin{array}{l}\text { F22-23; } \\
\text { F28-29 }\end{array}$ & \\
\hline $\begin{array}{l}\text { SD2 } \\
\text { SD3 }\end{array}$ & $\begin{array}{l}\mathrm{B} \rightarrow \mathrm{Si} \rightarrow \mathrm{Od} \rightarrow \\
\mathrm{So} \rightarrow \mathrm{D} \rightarrow \\
\mathrm{Sf} \rightarrow \mathrm{Hs}\end{array}$ & $\begin{array}{c}\text { G24 } \\
\text { G25-27 }\end{array}$ & $\begin{array}{l}\text { Various shades/ colors and soft } \\
\text { surface effect }\end{array}$ & $\begin{array}{l}\text { Rinse for over } \\
\text { dyed articles }\end{array}$ & F24-27 & $\begin{array}{l}\text { To remove the } \\
\text { sizing agents } \\
\text { and unfixed dyes }\end{array}$ \\
\hline SD6 & $\begin{array}{l}\mathrm{B} \rightarrow \mathrm{Si} \rightarrow \mathrm{Ds} \rightarrow \\
\mathrm{D} \rightarrow \mathrm{Sf} \rightarrow \mathrm{Ac} \rightarrow \\
\mathrm{So} \rightarrow \mathrm{D} \rightarrow \mathrm{Sf}\end{array}$ & G31 & $\begin{array}{l}\text { Surface effects contrasting or } \\
\text { tone-in-tone }\end{array}$ & \multirow{2}{*}{$\begin{array}{l}\text { Enzyme } \\
\text { washing } \\
\text { to imitate } \\
\text { stone washing }\end{array}$} & F31 & \multirow{2}{*}{$\begin{array}{l}\text { To achieve } \\
\text { a lightly worn } \\
\text { and faded look }\end{array}$} \\
\hline $\begin{array}{l}\text { SD5 } \\
\text { SD6 } \\
\text { SD7 }\end{array}$ & $\begin{array}{l}\mathrm{B} \rightarrow \mathrm{Si} \rightarrow \\
\mathrm{So} \rightarrow \mathrm{D} \rightarrow \mathrm{Sf}\end{array}$ & $\begin{array}{c}\text { G30; } \\
\text { G32-33; } \\
\text { G34-35 }\end{array}$ & Soft surface effect & & \begin{tabular}{|c|} 
F30; \\
F32-F35
\end{tabular} & \\
\hline
\end{tabular}

* Brushing (B); Singeing (Si); Caustification (C); Drying (D); Sanforizing (Sf); Acrylic coating (Ac); Softening (So); Resin treatment (Rt); Overdyeing (Od); Heat setting (Hs); Desizing (Ds).

Choosing the appropriate testing method: as to comply with the objectives of the present work, the descriptive test was chosen to characterize quantitatively, and, by inclusion qualitatively, a number of six specific sensory attributes (bipolar attributes) of the seventy stretch denim assortments, as fabric hand descriptors $[15,18]$.

Choosing sensory assessors for the panel configuration: for this work, the approach was different from the one specified by the standards, where for a quantitative descriptive sensory analysis, a panel of selected or expert assessors is needed. Here, were recruited sixteen second year students of textile bachelor level as panellists, with a slight background in textiles and without prior taking part in sensory sessions for descriptive tests approach, called naive assessors, the nomenclature being stated within standards $[15,19]$. During the recruitment and some coaching, it was obvious that all of them had unambiguous ideas about their expectations about the sensorial comfort of any item of women clothes as wearers. This was the idea of a "fresh panel" with some background in textile, used to wearing jeans, but as naive assessors when it comes to sensory analysis.

Training procedure for the sense of fabrics tactile properties: the group of naive assessors as panellists had to get a minimum training and was coached by facilitators (three teachers) to quantify and qualify their feelings when handling the stretch denim fabrics samples. The training enabled assessors to describe the product's sensory properties by using a given glossary of hand descriptive terms and with definitions for each one of the attributes. It also enabled assessors to handle the samples in a specific way, depending on the evaluated attribute. Table 3 shows the proper actions for the evaluation of the physical attributes by means of mechanical and surface properties of the fabric, in compliance with the criteria of Kawabata and AATCC Evaluation Procedure Appendix A [14-15, 18-19].

Quantifying the intensity of sensorial perceptions during the blind handling of fabrics: as naive assessors, the sixteen students learned about the glossary of descriptive terms and the attributes to be used for the evaluation of stretch denim. Subsequently, they learned to quantify their senses' intensity during the blind handling of fabrics, by scoring each sensory feature on a common intensity scale from a score sheet. As shown in table 3, for six mechanical and surface properties, two extreme values of the related physical attributes as fabric hand descriptors, called bipolar attributes, were established. To "translate" the tactile sensations into grades, the students were taught to use a rating scale for each bipolar attribute, with grades from 1 to 10 . For example, the selected attribute "flexible" as an extreme was assigned with the grade "one" (the most flexible) while the attribute for the other extreme ("stiff") received the grade "ten" (the most non-flexible); the meaning of grade "five" was that the fabric is felt as being moderately flexible/ stiff.

Other requirements and guidelines for deploying sensorial analysis trials: before the evaluations, all the samples were preserved under the standard atmospheric conditions and each evaluation session was performed under the same experimental conditions 
HANDLING FOR THE HUMAN PERCEPTION OF FABRIC PROPERTIES RELATED TO THE FABRIC HAND

\begin{tabular}{|c|c|c|}
\hline Handling for evaluation of the mechanical & d surface properties & $\begin{array}{l}\text { Bipolar physical attributes } \\
\text { as hand descriptors }\end{array}$ \\
\hline $\begin{array}{l}\text { Tensile properties assessment: by gripping the fabric } \\
\text { between two fingertips and by stretching it in the } \\
\text { orthogonal direction from the fixed fabric edge. }\end{array}$ & & Stretchable/Non-stretchable \\
\hline $\begin{array}{l}\text { Shear properties assessment: by squeezing the fabric } \\
\text { between two fingertips and by stretching it roundtrip, } \\
\text { in the parallel direction from the fixed fabric edge. }\end{array}$ & & Soft/Hard \\
\hline $\begin{array}{l}\text { Bending properties assessment: by providing a fabric } \\
\text { fold under its own weight and by gripping the fabric } \\
\text { between two fingertips. }\end{array}$ & & Flexible/Stiff \\
\hline $\begin{array}{l}\text { Compression properties assessment: by squeezing } \\
\text { the fabric in its thickness between two fingertips } \\
\text { without any other movement }\end{array}$ & & Thin/Thick \\
\hline $\begin{array}{l}\text { Surface properties assessment: by gently squeezing } \\
\text { the fabric in its thickness between two fingertips and } \\
\text { then sliding them in the orthogonal direction from the } \\
\text { fixed fabric edge. }\end{array}$ & at & Slippery/Rough \\
\hline $\begin{array}{l}\text { Weight assessment: by providing a free fabric fold, } \\
\text { under its own weight and then lifting it with the palm } \\
\text { of the hand }\end{array}$ & & Light/Heavy \\
\hline
\end{tabular}

$[15,17]$. The assessment technique applied for this study by the individual panellists was a "blind handling" with mono-sense approaches of each fabric hand descriptor and,all evaluation sessions received support from the facilitators. The samples of the same size $(200 \mathrm{~mm} \times 200 \mathrm{~mm})$ were randomly presented one-by-one to each assessor by the facilitators, inside special boxes without visual access but only accessible to the assessors' hands. Each item was assessed within the allowed time lapse (up to 10 seconds, for each sample and for each bipolar physical attribute). The facilitators provided students the monitoring of the handling technique, guided the succession of handling step by step for every hand descriptor and completed the evaluation sheets with reported grades by panellists, as their sensorial feeling quantification during the stretch denim fabrics handling.

\section{Statistical analysis strategy for the sensory results}

The panellist's performance checking is mandatory and needed specific techniques for the statistical analysis of the results [14-15, 20-21]. This paper will present two stages as successive approaches within the statistical analysis strategy for the overall sensory analysis data reported after the stretch denim fabric hand assessment, completed with the support of the interactive ICT-based learning tools previously developed STAT-Hand (Statistical Analysis for Hand) 
and STAT-ConCor (Statistical Analysis for Concordance and Correlation) [22-24].

\section{RESULTS AND DISCUSSION}

On the sensory profiles, after the blind subjective evaluation of stretch denim fabrics hand, for the analysis of the sensorial accuracy within the panel

In the first stage, the main issue was to get an image of the overall sensorial feelings accuracy within the panel, namely whether or not the students, as naive assessors, succeeded (while blind evaluating) to perceive and to quantify the sensory differences between samples of stretch denim as greige fabrics and, afterwards, as finished fabrics.

The STAT-Hand software application allowed generating the Sensory Profiles of Fabrics (SPF), of each of the seventy stretch denims, based on the assigned grades awarded by each of the sixteen students as naive assessors (E01 $\div$ E16) when quantifying their

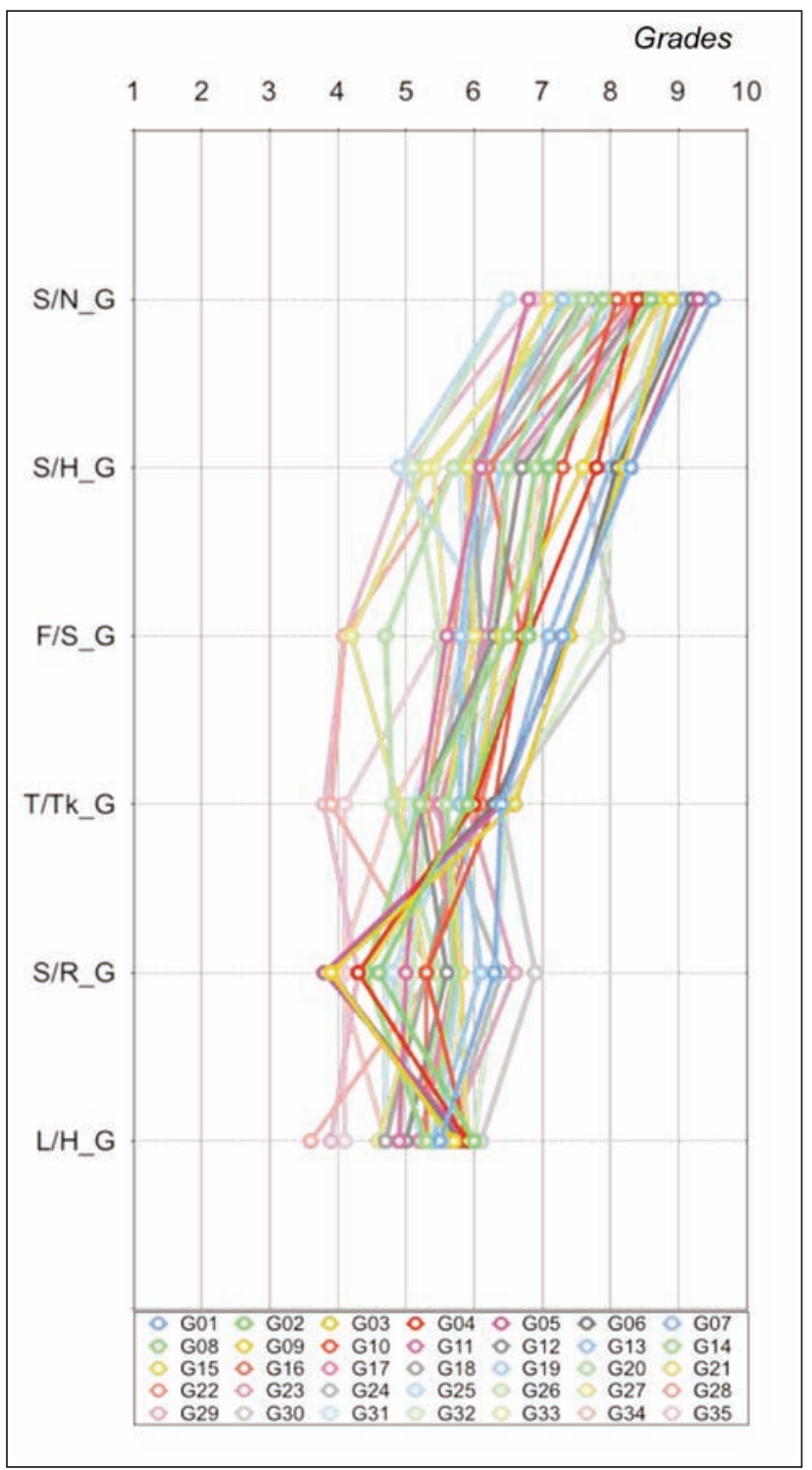

individual perceptions on the fabric hand descriptors, during the blind evaluation trials. During sensory analysis trials, a huge number of sensory profiles were obtained: an amount of 1,120 issued by sixteen evaluators for seventy fabrics, with 560 for each group of fabrics, as greige denim (G01 to G35) versus finished denim (F01 to F35). Consequently, it was considered as more useful to graphically represent the sensory profiles for the average of the ratings reported for each of the seventy stretch denim fabrics by the panellists.

Figure 1 shows the graphical representation of the average sensory profiles of seventy stretch denim fabrics after the blind evaluation, allowing a comparison in terms of similarity/dissimilarity between evaluations within the panel, considering all six bipolar attributes: stretchable/non-stretchable $(\mathrm{S} / \mathrm{N})$, soft/ hard $(S / H)$, flexible/stiff $(F / S)$, thin/thick (T/Tk), slippery/rough $(S / R)$, and light/heavy $(L / H)$.

The sensory profiles are as different as the fabrics are, remaining in a certain range of the rating scale

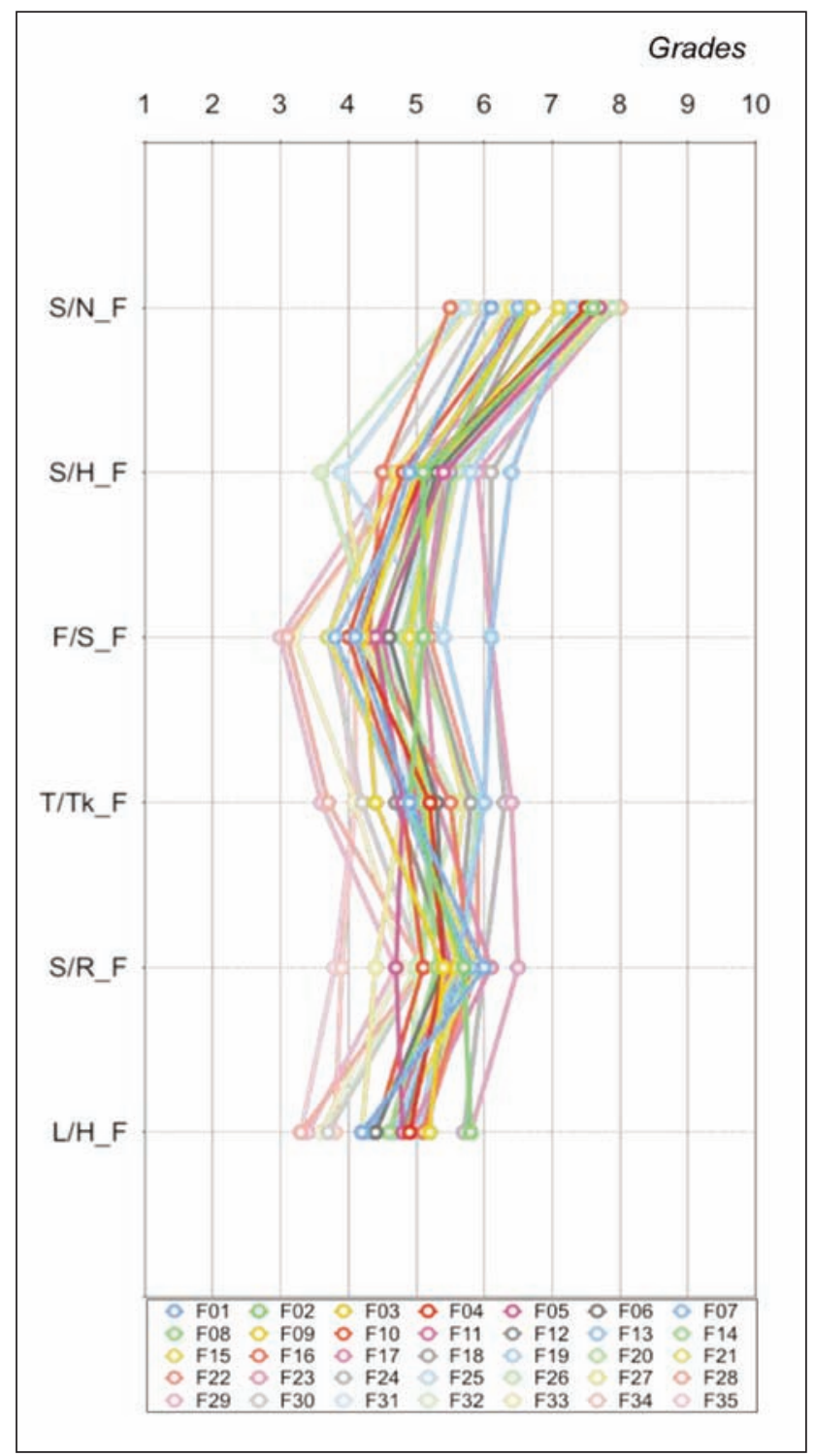

Fig. 1. Average sensory profiles generated by means blind evaluation of the stretch denims after two finishing processes: $a-$ SPF of greige denims; $b-$ SPF of finished denims 
for the entire assortment. It was obvious that there was a difference between the ways in which the hand descriptors have been perceived and reported by the panellists during handling for the two groups of fabrics, greige (after pre-finishing) and finished (after washing). Hence, during handling, the sixteen panellists felt the difference between the two fabric groups and, overall, the finished ones have each of the six bipolar attributes at a better level from the sensorial comfort point of view of the potential jeans consumers: the finished materials were felt with better elasticity, are softer, more flexible, rather thicker than thinner, and with medium level perceived smoothness and weight.

\section{On the sensory data analysis for the rating consistency evaluation within the panel of naive assessors}

The Kendall's concordance test was performed to determine if there was an agreement between the naive assessors of the entire panel, on the sensory analysis results separately reported on each sensory attribute as fabrics hand descriptor. During the blind subjective evaluation, each of the six bipolar attributes was quantified by all panellists and, to confirm the homogeneity of the panel in terms of the sensorial perceptions for which they have given grades to the same series of samples, the concordance between the assessors' judgments ought to be analysed.

The summary table 4 included the overall results of the Kendall's coefficients (W) for the greige stretch denims (G01 to G35) and finished stretch denims (F01 to F35) considering each of the six bipolar attributes: stretchable/non-stretchable, soft/hard, flexible/stiff, thin/thick, slippery/rough and light/heavy, as they were perceived by the naive assessors. In this table were also included the computed values for the statistical significance tests to prove Kendall's coefficients' statistical significance.

On a panel level, the best values of the Kendall coefficient, with moderate agreement between individuals, were obtained for bipolar attributes of the greige fabrics stretchable/non-stretchable, soft/hard and flexible/stiff. Regarding the thin/thick and slippery/ rough attributes, the values are good enough for the greige fabrics, which underline a lower to moderate agreement between individuals, and smaller values for the finished ones. Altogether, for the perception of the light/heavy bipolar attribute, the panellists seemed to be in the lowest agreement for greige and finished denims too. Following the results of the statistical significance test by comparing the computed values with the critical value $\left(\chi_{0.05 ; 34}^{2}=43.773\right)$, the coefficients of concordance came out as statistically significant at a confidence range of $95 \%$ (level of significance 0.05) for all bipolar attributes. Next to the significance test of the Kendall's coefficient of concordance, the overall situation strengthens the hypothesis that there is a convincing evidence of agreement between students as naive assessors during the blind handling evaluation of the stretch denims, with a moderate degree for more than half of the bipolar attributes, and with a lower than a middle degree for the other attributes, also depending on the finishing stage (greige or finished fabrics).

Subsequently, the initiated assessors should attend replicate sessions of sensory analysis for the seventy stretch denim fabrics, approached by a similar technique and pursuing the same tasks, as a step towards a new level of competences that shall be the selected sensory assessors' level.

\section{CONCLUSIONS}

This paper focused upon the sensory assessment of the tactile properties as descriptors of stretch denim fabric hand, for a wide range of seventy denims, evaluated after two successive finishing stages (applied in several variants), to confirm the existence of certain differences between fabrics, easy to distinguish by a panel of naive assessors, who could be usual jeans wearers. The stretch denim assortment was produced from seven articles in the loom-state phase by combining two types of right-hand twill, with $100 \%$ cotton in the warp system yarns and six mixture types in the weft system as core-spun yarns (cotton, cotton/elastane and cotton/elastane/polyester) incorporating different amounts of elastane $(1 \%, 2 \%$ and $8 \%)$

DATA ANALYSIS FOR THE RATING CONSISTENCY EVALUATION WITHIN THE PANEL OF SIXTEEN NAIVE ASSESSORS

\begin{tabular}{|c|c|c|c|c|c|c|c|c|c|c|c|}
\hline \multicolumn{12}{|c|}{ Kendall's coefficients of concordance, W } \\
\hline \multicolumn{2}{|c|}{$\begin{array}{c}\text { Stretchable/Non } \\
\text { Stretchable }\end{array}$} & \multicolumn{2}{|c|}{ Soft/Hard } & \multicolumn{2}{|c|}{ Flexible/Stiff } & \multicolumn{2}{|c|}{ Thin/Thick } & \multicolumn{2}{|c|}{ Slippery/Rough } & \multicolumn{2}{|c|}{ Light/Heavy } \\
\hline$W_{S / N G}$ & $\mathrm{~W}_{\mathrm{S} / \mathrm{N} F}$ & $W_{S / H G}$ & $\mathrm{~W}_{\mathrm{S} / \mathrm{H} \mathrm{F}}$ & $W_{F / S G}$ & $\mathrm{~W}_{\mathrm{F} / \mathrm{S} \mathrm{F}}$ & $\mathrm{W}_{\mathrm{T} / \mathrm{Tk} \mathrm{G}}$ & $\mathrm{W}_{\mathrm{T} / \mathrm{Tk} \mathrm{F}}$ & $W_{S / R G}$ & $\mathrm{~W}_{\mathrm{S} / \mathrm{R}_{-} \mathrm{F}}$ & $W_{L / H G}$ & $\mathrm{~W}_{\mathrm{L} / \mathrm{H} \mathrm{F}}$ \\
\hline 0.395 & 0.245 & 0.402 & 0.169 & 0.441 & 0.336 & 0.314 & 0.295 & 0.337 & 0.197 & 0.245 & 0.195 \\
\hline \multicolumn{12}{|c|}{ Chi-Squared Test - computed values of $\chi^{2}$} \\
\hline$X^{2} S / N \_G$ & $X^{2} S / N_{-} F$ & $X^{2} S / H \_G$ & $X^{2} S / H_{-} F$ & $\chi_{F / S \_G}^{2}$ & $\chi_{F / S+F}^{2}$ & $\chi^{2}{ }_{T / T K_{B} G}$ & $\chi_{T / T K_{F} F}^{2}$ & $\chi_{S / R \_G}^{2}$ & $\chi^{2} S / R_{-} F$ & $\chi_{L / H \_G}^{2}$ & $\chi_{L / H}^{2} \mathrm{~F}$ \\
\hline 214.8 & 133.2 & 218.7 & 91.9 & 239.9 & 182.8 & 170.8 & 160.4 & 183.3 & 107.2 & 133.2 & 106.1 \\
\hline
\end{tabular}

*The codification meaning example: $\mathrm{W}_{\mathrm{S} / \mathrm{N}_{-} \mathrm{G}}$ is the Kendall's coefficient of concordance computed for stretchable/non-stretchable bipolar attribute of the greige stretch denim. 
and polyester $(7 \%, 13 \%$ and $22 \%)$, subjected to six industrial pre-finishing processes and, subsequently, to four washing techniques.

The main findings following the statistical analysis of the sensory results should support the usefulness of the subject for the stretch denim fabrics producers, which now stand for a significant percentage of the global denim market. The sensory profiles allowed a comparison in terms of similarity/dissimilarity between evaluations within the panel, for all samples and considering all six bipolar attributes. Within the panel of naive assessors, the overall sensorial feelings accuracy during the blind subjective evaluation was good enough, since the difference between the two groups of fabrics (greige versus finished) was revealed by means of the sensory profiles. Subsequently, the Kendall's coefficients of concordances were convincing evidence of a moderate agreement between students as naive assessors, during the blind handling evaluation of stretch denim fabrics with multiple applied finishing and washing techniques.

This research was an attempt to suggest the idea that the need to feel the fabrics is self-understood for any buyer of clothing items, regardless whether they have a background in textile or not, or training in sensory analysis. For producers, it should be obvious that the naive assessors and, moreover, the untrained consumers' feelings about the fabric' sensorial comfort, could also be significant for a successful garment on the market.

As future work, the authors intend to conduct sensory evaluation sessions with potential wearers of special textile products, as features and destination, classified as smart textiles. Smart prototypes will be developed within the Skills4Smartex project and the panels of assessors will be made up of VET students, participants in the project activities. Both their training and the improvement of their skills of subjectively evaluating the intelligent textile products obtained in the project will be approached.

\section{ACKNOWLEDGEMENTS}

The authors would like to thank the management of UCO TESATURA Co. part of UCO RAYMOND Denim group for supplying the stretch denim fabrics, as well to acknowledge the support of the EC Programme Erasmus+, Project SKILLS4SMARTEX (no. 2018-1-RO01-KA202-049110).

\section{BIBLIOGRAPHY}

[1] ***Euromonitor International. Consumer Lifestyles in 2017: Global Survey Results, https://go.euromonitor.com (accessed December 2018).

[2] ***Global Denim Market Analysis and Forecast to 2023, (accessed April 2018).

[3] Harpa, R., Visileanu, E., From fabric design to the dress manufacturing, considering the fabric's suitability with the end use, In: Industria Textilă, 2018, 69, pp. 434-439

[4] Halleb, N.A., Sahnoun, M., Cheikhrouhou, M., The effect of washing treatments on the sensory properties of denim fabric, In: Text Res J, 2015, 85, 2, pp. 150-159

[5] Piroi, C., Harpa, R., Oprea, M., Regarding the effect of finishing processes on some properties of stretch denim fabrics, In: Aegean International Textile and Advanced Engineering Conference. IOP Conf. Series: Mater. Sci. Eng., 2018, 459012059

[6] Gengler, I., When People Are The Instrument: Sensory Evaluation Methods, In: ASQ Statistics division newsletter, 2009, 27-4 (accessed January 2018)

[7] Schacher, L., Bensaid, S., El-Ghezal, J., et al., Sensory and Physiological Issues, In: Vassiliadis, S., (Ed) Advances in Modern Woven Fabrics Technology. IntechOpen, 2011

[8] Naima, H.A., Mehdi, S., and Morched, C.H., Training and Control of Performance of a Tactile Sensory Panel., In: Journal of Applied Sciences, 2013, 13, pp. 366-376

[9] Harpa, R., Piroi, C., Blaga, M., Sensory analysis: approach for total handle evaluation of wool-type fabrics. In: IOP Conf. Ser.: Mater. Sci. Eng., 2019, 459. 012045

[10] Valatkienè, L., Strazdienè, E., Accuracy and Reliability of Fabric's Hand Subjective Evaluation, In: Mater. Sci. (Medžiagotyra), 2006, 12, pp. 253-257

[11] Melkie, G.T., Harpa, R., et al., Assessing the comfort of functional fabrics for smart clothing using subjective evaluation, In: J Ind Text, 2019, 48, 8, pp. 1310-1326

[12] ISO 20613:2019. Sensory analysis - General guidance for the application of sensory analysis in quality control

[13] Kanai, H., Morishima, M., Nasu, K., et al., Identification of principal factors of fabric aesthetics by the evaluation from experts on textiles and from untrained consumers, In: Text Res J, 2011, 81, 12, pp. 1216-1225

[14] AATCC EP 5:2011. Fabric Hand: Guidelines for the Subjective Evaluation of, In: AATCC Technical Manual, pp. 388-390

[15] ISO 6658: 2017. Sensory analysis - Methodology - General guidance

[16] ISO 5492:2009. Sensory analysis - Vocabulary

[17] ISO 8589:2017. Sensory analysis - General guidance for the design of test rooms 
[18] ISO 11035:2015. Sensory analysis - Identification and selection of descriptors for establishing a sensory profile by a multidimensional approach

[19] ISO 8586:2014. Sensory analysis - General guidelines for the selection, training and monitoring of selected assessors and expert sensory assessors

[20] ISO 11132:2012. Sensory analysis - Methodology - Guidelines for monitoring the performance of a quantitative sensory panel

[21] ISO 13299:2016. Sensory analysis - Methodology - General guidance for establishing a sensory profile.

[22] Bona M., Statistical methods for the Textile Industry. Eurotex-Textilia, 1993

[23] Harpa, R., Fabric Hand: Approach by Means of Software Package for Teaching Students. Part II - Software Applications, In: 12th Int. Scientific Conf. on eLearning and Software for Education(edRoceanu I), 2016, 3, pp. 518-525

[24] Harpa, R., Cristian, I., Piroi, C., STAT-CONCOR: Software for Validating the Panel of Assessors, Subsequently to the Fabric Hand Evaluation, In: 13th Int. Scientific Conf. on eLearning and Software for Education(edRoceanu I), 2017, 3, pp. 431-438

\section{Authors:}

\section{RODICA HARPA ${ }^{1}$, CRISTINA PIROI ${ }^{1}$, IRINA CRISTIAN ${ }^{1}$, EMILIA VISILEANU², MIRELA BLAGA ${ }^{1}$}

1"Gheorghe Asachi” Technical University of Iasi, Faculty of Industrial Design and Business Management, Textile Engineering and Design Department, 29 D. Mangeron Blvd., 700050, Iasi, Romania

$$
\text { e-mail: rharpa@tex.tuiasi.ro }
$$

${ }^{2}$ INCDTP - The Research-Development National Institute for Textiles and Leather,

16 Lucrețiu Pătrășcanu Street, 030508, Bucharest, Romania

e-mail: office@incdtp.ro

Corresponding author:

\section{RODICA HARPA}

e-mail: rharpa@tex.tuiasi.ro 


\title{
Performance enhancement of diammonium hydrogen phosphate as halogen and formaldehyde free sustainable fire retardant
}

\author{
DOI: 10.35530/IT.070.04.1606
}

\section{REZUMAT - ABSTRACT}

\author{
Îmbunătățirea performanței hidrogenofosfatului de diamoniu ca ignifugant durabil fără halogen \\ și formaldehidă
}

\begin{abstract}
Ignifuganții pe bază de fosfor sunt utilizați în general pentru a conferi un caracter ignifug țesăturii de bumbac. Cu toate acestea, majoritatea ignifuganților eficienți pe bază de fosfor pentru textile conțin halogen toxic și/sau formaldehidă. Hidrogenofosfatul de diamoniu nu conține halogen sau formaldehidă, dar performanța sa este mult mai mică decât a substanțelor ignifuge disponibile în comerț. Prin urmare, în acest studiu, hidrogenofosfatul de diamoniu a fost polimerizat cu agenți de reticulare fără conţinut de formaldehidă, cum ar fi acidul acrilic și acidul maleic. Concentrațiile de monomeri și inițiatori, condițiile de polimerizare și temperatura au fost optimizate. Țesătura tratată pe baza noii rețete a prezentat performanțe bune de ignifugare, precum și proprietăți suplimentare ale controlului contracției, îngrijire ușoară și proprietăți antimicrobiene. Testarea analitică SEM, FTIR și a conținutului de fosfor a confirmat, de asemenea, aplicarea cu succes a finisajului.
\end{abstract}

Cuvinte-cheie: ignifugant, finisare cu îngrijire ușoară, controlul contracției, antimicrobian, sare de fosfat

\section{Performance enhancement of diammonium hydrogen phosphate as halogen and formaldehyde free sustainable fire retardant}

Phosphorous based fire retardants are commonly used for imparting fire retardancy to the cotton fabric. However, most of theeffective phosphorous based fire retardants for textile contain toxic halogen and/or formaldehyde. Diammonium hydrogen phosphate does not contain halogen or formaldehyde but its performance is far less than the commercially available fire retardants. Therefore, in this research Diammonium hydrogen phosphate was polymerized with zero formaldehyde based cross-linkers like acrylic acid and maleic acid. Concentrations of monomers and initiator, polymerization conditions and temperature were optimized. Newly developed recipe treated fabric exhibited good fire retardancy performance as well as additional properties of shrinkage control, easy care and anti-microbial. Analytical testing of SEM, FTIR and phosphorous content also confirmed the successful application of the finish.

Keywords: fire retardant, easy carefinishing, shrinkage control, anti-microbial, phosphate salt

\section{INTRODUCTION}

Fire play vital role in our lives. However, it is very dangerous when out of control. Over 0.3 million people die andmany more get injured while billions of loss in property is reported every year due to fire breakout. According to fire hazard statistics of United State of America 2015, the fire department has responded to an estimated 1,345,500 fire incidents; over 1570 civilians died during these fire incidents and 14.3 billion dollar direct property loss was reported [1-2]. Carpets, upholstery and most importantly textile apparel are the last barrier for fire before it can cause harm to humans. Therefore, fire retardant chemicals consumption are increasing and it was worth more than 5.6 billion pounds in 2017. There is no doubt that cotton is the most widely used natural fiber but it lacks fire retardancy, in fact it will spread more fire once ignited [3-5].

It is unfortunate that the most widely used fire retardants for textile like Pyrovatex CP New (modified
$\mathrm{N}$-methyloldimethylphosphonopropionamide) and THPC (Tetrakishydroxymethylphosphonium chloride) are not environment friendly. Pyrovatex contain carcinogenic formaldehyde while THPC required nonconventional and non-environment friendly ammonia chamber [6-9].

Zero discharge of hazardous chemicals (ZDHC) program, vision 2020 and its signatory brands have included the conventional effective halogenated fire retardants in their 11 banned priority chemicals. In addition, certifications for organic textile products also prohibit the use of halogen and formaldehyde based fire repellents. Therefore, researchers are working on finding the effective alternatives. Ammonium phosphate salts are one such alternative [10] but its performance is far less than the commercial Pyrovatex and THPC. Carboxylic acids are good alternative for formaldehyde based cross-linkers [11-14]. Researchers have reported the use of butane tetra carboxylic acid (BTCA) as fire retardant enhancer with Pyrovatex but BTCA is very expensive and 
Pyrovatexitself is toxic. Certain cost effective carboxylic acids like maleic acid (di carboxylic acid) with C6 fluorocarbon has been reported as oil and water repellent [15] while acrylic acid (mono carboxylic acid) as surface modifier for textile fabric.

Diammonium hydrogen phosphate (DAHP) has been reported as environment friendly, non-toxic and cost effective fire retardant for textile. However, its performance is much less than the commercially available products. Researchers have reported the use of melamine formaldehyde [16] as enhancer with DAHP but melamine formaldehyde contains carcinogenic formaldehyde. In this research DAHP is polymerized withformaldehyde freecross-linkers; maleic acid and acrylic acid under normal atmosphere and nitrogen atmosphere at various conditions. The performance of the newly polymerized recipes was assessed on the cotton fabric.

\section{EXPERIMENTAL WORK}

\section{Materials and methods}

In this research $100 \%$ cottonbleached fabric with 280 GSM was used. Following lab grade chemicals; Diammonium hydrogen phosphate (DAHP), sodium hypophosphite (SHSP), acrylic acid, potassium per sulfate (PPS) and maleic acid were purchased from Sigma Aldrich.

\section{Methods}

In this research non-toxic and formaldehyde free cross-linkers like acrylic acid and maleic acid have been used along with halogen free fire retardant monomer; diammonium hydrogen phosphate (DAHP). Concentrations of DAHP and cross-linkers as well as temperature of polymerization were optimized. The polymerization time was optimized for one hour. Potassium per sulfate was used as initiator and sodium hypophosphite as catalyst. The polymerized recipe was applied through padding by using $80 \%$ pick up. Drying was carried out at hundred degrees for three minutes while curing was performed at one hundred and eighty degrees for two minutes. All the samples were conditioned at $65 \%$ relative humidity and $20^{\circ} \mathrm{C}$ prior to any testing. Limiting oxygen index was assessed by the standard method of ASTM D 2863. BS 5438: 1989, Test 2B vertical burning test was performed to measure the damaged char length and width. Crease recovery and shrinkage were assessed by using BS EN 22313: 1992 and AATCC test method 135: 2004 respectively. AATCC 147 test method was performed to determine the antimicrobial performance. The air permeability was measured by using method D737: 1996. Olsen method [17] was used to measure the concentration of phosphorous. FTIR was also performed for samples with 32 background scan and from wave number range of 650 to $4000 \mathrm{~cm}^{-1}$. Gold coating treatment was carried out before performing SEM analysis.

\section{RESULTS AND DISCUSSIONS}

Untreated control cotton fabric was burnt immediately and completely. One of the most commonly used fire retardant for textile, Pyrovatex, has been used as bench mark in this study. Manufacturer suggested recipe of $20 \%$ Pyrovatexalong with $1.5 \%$ of formaldehyde based trimethylol melamine catalyst $\mathrm{CHN}$ and $2.5 \%$ of phosphoric acid was applied on to the treated fabric. The treated samples have exhibited the char length of $98 \mathrm{~mm}$ and char width of $32 \mathrm{~mm}$ (table 1). By raising the quantity of Pyrovatex from $20 \%$ to $40 \%$ there was further improvement in the fire retardancy, consequently, char length and width of $64 \mathrm{~mm}$ and $28 \mathrm{~mm}$ respectively were obtained (table 1). Performance of the diammonium hydrogen phosphate (DAHP) was also assessed at the level of $5 \%$, $10 \%, 20 \%$ and $40 \%$. Char length and width were reduced by increasing the quantity of DAHP. The reduction in char length and width is higher at low levels of DAHP and slowed down after $20 \%$ due to saturation effect.

\begin{tabular}{|c|c|c|c|}
\hline \multicolumn{4}{|c|}{ FIRE RETARDANCY OF PYROVATEX } \\
AND DIAMMONIUM HYDROGEN PHOSPHATE \\
TREATED COTTON \\
\hline $\begin{array}{c}\text { Fire } \\
\text { retardant } \\
\text { chemical }\end{array}$ & $\begin{array}{c}\text { Catalyst/ } \\
\text { Cross-linker }\end{array}$ & $\begin{array}{c}\text { Char } \\
\text { length } \\
\text { (mm) }\end{array}$ & $\begin{array}{c}\text { Char } \\
\text { width } \\
\text { (mm) }\end{array}$ \\
\hline $\begin{array}{c}\text { Control fabric } \\
\text { Tmmete } \\
20 \%\end{array}$ & $\begin{array}{c}\text { Complete } \\
\text { burn }\end{array}$ & $\begin{array}{c}\text { Complete } \\
\text { burn }\end{array}$ \\
\hline $\begin{array}{c}\text { Pyrovatex, } \\
\text { acid 2.5\%, }\end{array}$ & 98 & 32 \\
\hline $\begin{array}{c}\text { Pyrovatex, } \\
40 \%\end{array}$ & $\begin{array}{c}\text { Phosphoric acid 6\%, } \\
\text { Catalyst (CHN) 2.2\% }\end{array}$ & 64 & 28 \\
\hline DAHP, 5\% & - & 184 & 46 \\
\hline DAHP, 10\% & - & 142 & 41 \\
\hline DAHP, 20\% & - & 101 & 32 \\
\hline DAHP, 40\% & - & 95 & 28 \\
\hline
\end{tabular}

\section{Preparation of fire retardant and its application} to the cotton fabric

The cotton fabric treated with maleic acid was burnt completely and did not show any kind of fire retardancy. Table 2 represent the results of polymerization at normal atmosphere. Increasing the polymerization temperature from $25^{\circ} \mathrm{C}$ to $120^{\circ} \mathrm{C}$ exhibited reduction in the char length. Nevertheless, polymerization temperature greater than $120^{\circ} \mathrm{C}$ imparted no improvement.

Alone acrylic acid treated cotton fabric was also burnt completely. Table 3 exhibited the results of polymerization between DAHP and acrylic acid where atmosphere is not controlled. In the case of acrylic acid polymerization with DAHP the char length was decreased by raising the temperature from $25^{\circ} \mathrm{C}$ to $90^{\circ} \mathrm{C}$ and after that there was no improvement. 
EFFECT OF TEMPERATURE ON POLYMERIZATION OF MALEIC ACID AT NORMAL ATMOSPHERE

\begin{tabular}{|c|c|c|c|c|}
\hline $\begin{array}{c}\text { Fire retardant } \\
\text { chemical DAHP (\%) }\end{array}$ & $\begin{array}{c}\text { Cross linker } \\
\text { Maleic acid (\%) }\end{array}$ & $\begin{array}{c}\text { Polymerization } \\
\left.\text { temperature } \mathbf{(}^{\circ} \mathbf{C}\right)\end{array}$ & $\begin{array}{c}\text { Char length } \\
(\mathbf{m m})\end{array}$ & $\begin{array}{c}\text { Char width } \\
(\mathbf{m m})\end{array}$ \\
\hline- & 5 & - & Complete burn & Complete burn \\
\hline- & 10 & - & Complete burn & Complete burn \\
\hline- & 15 & 25 & 136 & Complete burn \\
\hline 10 & 10 & 80 & 129 & 41 \\
\hline 10 & 10 & 100 & 126 & 36 \\
\hline 10 & 10 & 120 & 119 & 33 \\
\hline 10 & 10 & 140 & 119 & 33 \\
\hline 10 & 10 & 160 & 134 & 37 \\
\hline 10 & 10 & & & \\
\hline
\end{tabular}

Table 3

EFFECT OF TEMPERATURE ON POLYMERIZATION OF ACRYLIC ACID AT NORMAL ATMOSPHERE

\begin{tabular}{|c|c|c|c|c|}
\hline $\begin{array}{c}\text { Fire retardant } \\
\text { chemical DAHP (\%) }\end{array}$ & $\begin{array}{c}\text { Cross linker } \\
\text { Acrylic acid }(\%)\end{array}$ & $\begin{array}{c}\text { Polymerization } \\
\left.\text { temperature } \mathbf{~}^{\circ} \mathbf{C}\right)\end{array}$ & $\begin{array}{c}\text { Char length } \\
(\mathbf{m m})\end{array}$ & $\begin{array}{c}\text { Char width } \\
(\mathbf{m m})\end{array}$ \\
\hline- & 5 & - & Complete burn & Complete burn \\
\hline- & 10 & - & Complete burn & Complete burn \\
\hline- & 15 & - & Complete burn & Complete burn \\
\hline 10 & 10 & 25 & 129 & 33 \\
\hline 10 & 10 & 50 & 116 & 31 \\
\hline 10 & 10 & 75 & 102 & 31 \\
\hline 10 & 10 & 90 & 70 & 30 \\
\hline 10 & 10 & 100 & 72 & 30 \\
\hline
\end{tabular}

Typically, lot of side reactions can take place under atmospheric conditions. In addition, nitrogen in combination with phosphorous can improve the fire retardancy of the fabric. Therefore, polymerization was also performed in nitrogen atmosphere. Improved fire retardancy was achieved when polymerization was carried out under nitrogen atmosphere with DAHP and maleic acid. The minimum char length and width was achieved at the polymerization temperature of $120^{\circ} \mathrm{C}$ (table 4 ).

Similarly, acrylic acid was also polymerized with DAHP in nitrogen atmosphere. The minimum burnt char length and width was observed at $90^{\circ} \mathrm{C}$ as shown in table 5 . Similarly the improvement in the char length and width can easily be noticed when the polymerization was carried out under nitrogen atmosphere as compared to normal atmosphere.

Diammonium hydrogen phosphate was polymerized with maleic acid and acrylic acid without catalyst and initiator, with catalyst and without initiator, with catalyst and initiator under nitrogen atmosphere at $120^{\circ} \mathrm{C}$ and $90^{\circ} \mathrm{C}$ respectively as shown in table 6 . Potassium per sulfate was also used in polymerization because it is a well-known initiator. In addition, sodium hypo phosphite has been reported as catalyst for carboxylic acids [11], consequently, it was used in the

Table 4

EFFECT OF TEMPERATURE ON POLYMERIZATION OF MALEIC ACID UNDER NITROGEN ATMOSPHERE

\begin{tabular}{|c|c|c|c|c|}
\hline $\begin{array}{c}\text { Fire retardant } \\
\text { chemical DAHP (\%) }\end{array}$ & $\begin{array}{c}\text { Cross linker } \\
\text { Maleic acid (\%) }\end{array}$ & $\begin{array}{c}\text { Polymerization } \\
\left.\text { temperature } \mathbf{~}^{\circ} \mathbf{C}\right)\end{array}$ & $\begin{array}{c}\text { Char length } \\
(\mathbf{m m})\end{array}$ & $\begin{array}{c}\text { Char width } \\
(\mathbf{m m})\end{array}$ \\
\hline 10 & 10 & 25 & 113 & 36 \\
\hline 10 & 10 & 80 & 109 & 34 \\
\hline 10 & 10 & 100 & 95 & 33 \\
\hline 10 & 10 & 120 & 85 & 21 \\
\hline 10 & 10 & 140 & 90 & 25 \\
\hline 10 & 10 & 160 & 91 & 24 \\
\hline
\end{tabular}


EFFECT OF TEMPERATURE ON POLYMERIZATION OF ACRYLIC ACID UNDER NITROGEN ATMOSPHERE

\begin{tabular}{|c|c|c|c|c|}
\hline $\begin{array}{c}\text { Fire retardant } \\
\text { chemical DAHP (\%) }\end{array}$ & $\begin{array}{c}\text { Cross linker } \\
\text { Acrylic acid (\%) }\end{array}$ & $\begin{array}{c}\text { Polymerization } \\
\left.\text { temperature ( }{ }^{\circ} \mathbf{C}\right)\end{array}$ & $\begin{array}{c}\text { Char length } \\
(\mathbf{m m})\end{array}$ & $\begin{array}{c}\text { Char width } \\
\text { (mm) }\end{array}$ \\
\hline 10 & 10 & 25 & 88 & 39 \\
\hline 10 & 10 & 50 & 97 & 30 \\
\hline 10 & 10 & 75 & 68 & 28 \\
\hline 10 & 10 & 90 & 26 & 27 \\
\hline 10 & 10 & 100 & 39 & 28 \\
\hline
\end{tabular}

\begin{tabular}{|c|c|c|c|c|c|c|c|}
\hline \multicolumn{6}{|c|}{ EFFECT OF CATALYST AND INITIATOR ON POLYMERIZATION UNDER NITROGEN ATMOSPHERE } \\
\hline $\begin{array}{c}\text { Fire retardant } \\
\text { chemical }\end{array}$ & $\begin{array}{c}\text { Cross } \\
\text { linker }\end{array}$ & $\begin{array}{c}\text { Cross } \\
\text { linker }\end{array}$ & Catalyst & Initiator & $\begin{array}{c}\text { Polymerization } \\
\text { temperature } \\
\text { ( } \mathbf{C})\end{array}$ & $\begin{array}{c}\text { Char } \\
\text { length } \\
\text { (mm) }\end{array}$ & $\begin{array}{c}\text { Char } \\
\text { width } \\
\text { (mm) }\end{array}$ \\
\hline $\begin{array}{c}\text { DAHP } \\
(\%)\end{array}$ & $\begin{array}{c}\text { Maleic acid } \\
(\%)\end{array}$ & Acrylic acid & $\begin{array}{c}\text { Sodium } \\
\text { hypophosphite (\%) }\end{array}$ & $\begin{array}{c}\text { Potassium per } \\
\text { sulfate (\%) }\end{array}$ & & & \\
\hline 10 & 10 & - & - & - & 120 & 85 & 21 \\
\hline 10 & 10 & - & 8 & - & 120 & 81 & 19 \\
\hline 10 & 10 & - & 8 & 0.01 & 120 & 66 & 19 \\
\hline 10 & 10 & - & 8 & 0.02 & 120 & 39 & 16 \\
\hline 10 & 10 & - & 8 & 0.03 & 120 & 43 & 22 \\
\hline 10 & - & 10 & & - & 90 & 26 & 27 \\
\hline 10 & - & 10 & 8 & - & 90 & 25 & 27 \\
\hline 10 & - & 10 & 8 & 0.1 & 90 & 19 & 26 \\
\hline 10 & - & 10 & 8 & 0.2 & 90 & 15 & 25 \\
\hline 10 & - & 10 & 8 & 0.3 & 90 & 16 & 25 \\
\hline
\end{tabular}

polymerization. The most effective results were obtained with catalyst and initiator. The optimum amount of potassium per sulfate was $0.02 \%$ as exhibited in table 6. Therefore, sodium hypophosphite and potassium per sulfate were used as catalyst and initiator respectively in the remaining research.
The diammonium hydrogen phosphate was polymerized with maleic acid and acrylic acid under nitrogen atmosphere with catalyst and initiator at optimum temperature with various levels of DAHP, maleic acid and acrylic acidas shown in table 7 . The optimum results were achieved when $10 \%$ diammonium hydrogen

Table 7

\begin{tabular}{|c|c|c|c|c|c|c|c|}
\hline \multicolumn{8}{|c|}{$\begin{array}{l}\text { EFFECT OF CONCENTRATION OF FIRE RETARDANT MONOMER AND CROSS-LINKER AT OPTIMUM } \\
\text { TEMPERATURE WITH CATALYST AND INITIATOR UNDER NITROGEN ATMOSPHERE }\end{array}$} \\
\hline $\begin{array}{l}\text { Fire retardant } \\
\text { chemical }\end{array}$ & $\begin{array}{l}\text { Cross } \\
\text { linker }\end{array}$ & $\begin{array}{l}\text { Cross } \\
\text { linker }\end{array}$ & Catalyst & Initiator & $\begin{array}{l}\text { Polymerization } \\
\text { temperature } \\
\left({ }^{\circ} \mathrm{C}\right)\end{array}$ & $\begin{array}{l}\text { Char } \\
\text { length } \\
(\mathrm{mm})\end{array}$ & $\begin{array}{l}\text { Char } \\
\text { width } \\
\text { (mm) }\end{array}$ \\
\hline $\begin{array}{l}\text { DAHP } \\
(\%)\end{array}$ & $\begin{array}{l}\text { Maleic acid } \\
\quad(\%)\end{array}$ & Acrylic acid & $\begin{array}{c}\text { Sodium } \\
\text { hypophosphite (\%) }\end{array}$ & $\begin{array}{l}\text { Potassium per } \\
\text { sulfate }(\%)\end{array}$ & - & - & - \\
\hline 10 & 5 & - & 8 & 0.01 & 120 & 53 & 24 \\
\hline 10 & 10 & - & 8 & 0.02 & 120 & 39 & 16 \\
\hline 10 & 15 & - & 8 & 0.03 & 120 & 40 & 17 \\
\hline 5 & 10 & - & 8 & 0.02 & 120 & 83 & 39 \\
\hline 10 & 10 & - & 8 & 0.02 & 120 & 39 & 16 \\
\hline 15 & 10 & - & 8 & 0.02 & 120 & 38 & 16 \\
\hline 10 & - & 5 & 8 & 0.1 & 90 & 21 & 25 \\
\hline 10 & - & 10 & 8 & 0.2 & 90 & 15 & 25 \\
\hline 10 & - & 15 & 8 & 0.3 & 90 & 33 & 30 \\
\hline 5 & - & 10 & 8 & 0.2 & 90 & 49 & 36 \\
\hline 10 & - & 10 & 8 & 0.2 & 90 & 15 & 25 \\
\hline 15 & - & 10 & 8 & 0.2 & 90 & 17 & 26 \\
\hline
\end{tabular}




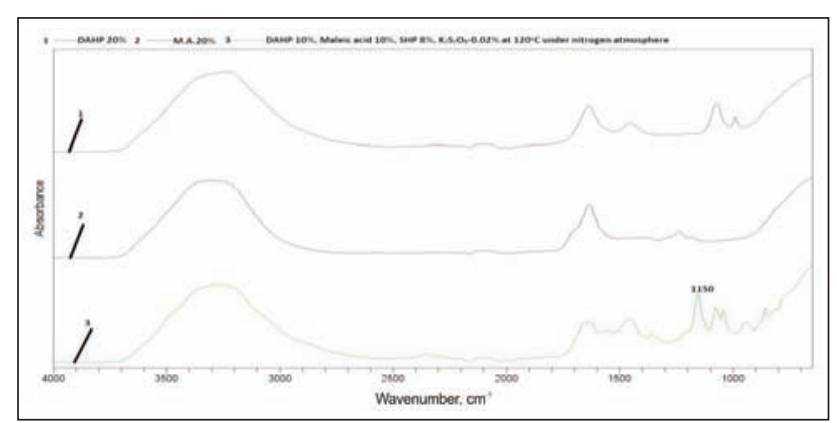

Fig. 1. FTIR analysis with maleic acid recipe

phosphate was polymerized with $10 \%$ maleic acid, $8 \%$ sodium hypophosphite and $0.2 \%$ potassium per sulfate. Similar conditions were repeated with $10 \%$ acrylic acid as well.

FTIR analysis were performed on the range of recipes; DAHP ( $20 \%$ solution in water), maleic acid ( $20 \%$ solution in water) and best polymerized recipe with maleic acid as shown in figure 1. FTIR were also performed on acrylic acid ( $20 \%$ solution in water) and best polymerized recipe with acrylic acid, figure 2 . The optimized recipes in case of maleic acid and acrylic acid along with DAHP, sodium hypophosphite, potassium per sulphate at $120^{\circ}$ under nitrogen atmosphere exhibited the prominent ester peaks at 1150 $\mathrm{cm}^{-1}$ and $1161 \mathrm{~cm}^{-1}$ respectively. Consequently, formation of effective ester bonding can be confirmed from the FTIR analysis. P-O-C stretch has been exhibited at the 920-1088 $\mathrm{cm}^{-1}$ for DAHP and best recipe either with maleic acid or acrylic acid, however, no such peak can be observed for alone maleic acid or acrylic acid.

\section{Physical and mechanical properties of cotton fabric}

Measurement of fire retardancy through objective testing like limiting oxygen index (LOI) \% is also important. Therefore, LOI \% of the selected samples was also performed. More the percentage of LOI better will be the fire retardancy. LOI of the control fabric was $18.1 \%$ indicating that it will easily catch the fire. Similarly, the maleic acid (20\%) and acrylic acid $(20 \%)$ treated fabric imparted the LOI\% of $18.2 \%$, demonstrating that there is hardly any improvement in the fire retardancy of the treated fabric when both carboxylic acids are used. The benchmark sample of $40 \%$ Pyrovatex treated fabric exhibited good LOI\% of $34.1 \%$. 20\% DAHP treated fabric exhibited LOI\% of 24.1. In case of cotton fabric treated with $10 \%$ maleic acid along with $10 \%$ diammonium hydrogen phosphate, $8 \%$ sodium hypophosphite, $0.2 \%$ potassium per sulfate the best LOI reported was $29.1 \%$. However, the highest LOI\% of $34.8 \%$ was achieved when cotton fabric was treated with $10 \%$ acrylic acid, $10 \%$ DAHP, $8 \%$ sodium hypophosphite and $0.2 \%$ potassium per sulfate. It can easily be said from tables $7 \& 8$ that both char length-width and LOI\% demonstrated similar trends.

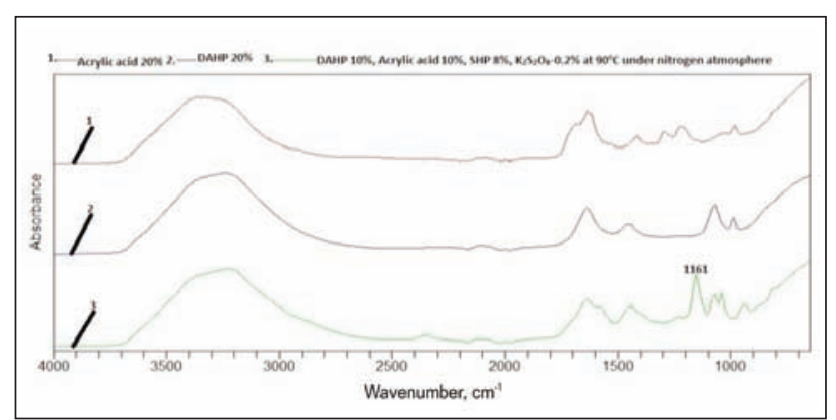

Fig. 2. FTIR analysis with acrylic acid recipe

Spread of fire through smoldering cigarette is very common all around the world. Therefore, smoldering cigarette test is performed on the cotton fabric samples. It was noticed as expected that control cotton fabric burnt easily. $40 \%$ Pyrovatextreated fabric was burnt in significant high time of 31 minutes. The highest burnt time of 32 minutes was achieved for the cotton fabric treated with DAHP $10 \%$,acrylic acid $10 \%$, catalyst $8 \%$ and initiator $0.02 \%$ (table 8 ).

Cotton fabric lacks the easy care properties and demonstrated the low crease recovery angle (table 8). It is mainly due to more amorphous region around $30 \%$ in the cotton as well as weak hydrogen bonding. Maleic acid and acrylic acid are both cross-linkers and consequently improved the bonding of the cellulose chains, therefore crease recovery is improved as compared to control cotton fabric. DAHP is not an effective cross-linker, therefore, improvement was minimal. However, crease recovery angle was significantly increased when DAHP10\% with maleic acid $10 \%$, catalyst $8 \%$ and initiator $0.2 \%$ were applied onto the fabric after the polymerization at $120^{\circ} \mathrm{C}$ under nitrogen atmosphere (table 8). It can also be concluded that due to new recipe effective bonding with the treated fabric, there was improvement in the fire retardancy and crease recovery angle.

One of the advantages of cotton fabric is its good air permeability. Therefore, control fabric air permeability is set as $100 \%$. Maleic acid, acrylic acid and DAHP exhibited slight decrease in the air permeability as these chemical coating on the cotton fabric will prevent the air permeability. Pyrovatex at the higher level of $40 \%$ exhibited the least air permeability retention of $69 \%$ due to more sever coating onto the cotton fabric at high dosage. The best recipe of maleic acid along with DAHP and others exhibited the reasonable air permeability retention of $86 \%$.

As mentioned above that cotton has amorphous region as well as weak hydrogen bonding, consequently, cotton fabric demonstrated shrinkage after washing due to lack of strong forces. However, maleic acid and acrylic acid treated fabric exhibited good shrinkage control due to the cross-linking of the cellulose chains. It was also not surprising that the best recipe of maleic acid along with DAHP, catalyst and initiator exhibited the best shrinkage control results due to their effective cross-linking.

Fire retardant finish performance can be determined through its phosphorous content as well. Therefore, 


\begin{tabular}{|c|c|c|c|c|c|c|}
\hline \multicolumn{7}{|c|}{ LOI\% OF VARIOUSFIRE RETARDANTS } \\
\hline Sample type & $\begin{array}{l}\text { Limiting } \\
\text { oxygen } \\
\text { index }(\%)\end{array}$ & $\begin{array}{l}\text { Crease } \\
\text { recovery } \\
\text { angle } \\
\text { (degree) }\end{array}$ & $\begin{array}{c}\text { Air } \\
\text { permeability } \\
\text { (\% retention) }\end{array}$ & $\begin{array}{c}\text { Shrinkage } \\
\text { of fabric } \\
\text { in warp } \\
\text { direction (\%) }\end{array}$ & $\begin{array}{l}\text { Shrinkage of } \\
\text { fabric in weft } \\
\text { direction (\%) }\end{array}$ & $\begin{array}{l}\text { Smoldering } \\
\text { cigarette test } \\
\text { results } \\
\text { (minutes) }\end{array}$ \\
\hline Control fabric & 18.1 & 137 & 100 & 7.6 & 6.2 & 11 \\
\hline Maleic acid & 18.2 & 208 & 91 & 2.2 & 1.1 & 12 \\
\hline Acrylic acid & 18.2 & 205 & 91 & 2.2 & 1.1 & 11 \\
\hline DAHP & 24.1 & 141 & 88 & 3.4 & 2.1 & 14 \\
\hline Pyrovatex $20 \%$ & 27.5 & 168 & 85 & 3.7 & 3.2 & 17 \\
\hline Pyrovatex $40 \%$ & 34.1 & 179 & 69 & 2.8 & 2.4 & 31 \\
\hline $\begin{array}{c}\text { DAHP } 10 \%+\text { Maleic acid } \\
10 \% \text { at } 120^{\circ} \mathrm{C} \text { under } \\
\text { nitrogen atmosphere }\end{array}$ & 24.8 & 195 & 87 & 2.1 & 1.6 & 15 \\
\hline $\begin{array}{c}\text { DAHP } 10 \%+\text { Acrylic acid } \\
10 \% \text { at } 90^{\circ} \mathrm{C} \text { under nitrogen } \\
\text { atmosphere }\end{array}$ & 25.1 & 189 & 88 & 2.1 & 1.6 & 16 \\
\hline $\begin{array}{c}\text { DAHP } 10 \%+\text { Maleic acid } \\
10 \%+\text { SHP } 8 \%+\mathrm{K}_{2} \mathrm{~S}_{2} \mathrm{O}_{8} \\
0.2 \% \text { at } 120^{\circ} \mathrm{C} \text { under } \\
\text { nitrogen atmosphere }\end{array}$ & 29.1 & 211 & 86 & 1.7 & 1.2 & 30 \\
\hline $\begin{array}{c}\text { DAHP } 10 \%+\text { Acrylic acid } \\
10 \%+\mathrm{SHP} 8 \%+\mathrm{K}_{2} \mathrm{~S}_{2} \mathrm{O}_{8} \\
0.2 \% \text { at } 90^{\circ} \mathrm{C} \text { under } \\
\text { nitrogen atmosphere }\end{array}$ & 34.8 & 208 & 86 & 1.8 & 1.2 & 32 \\
\hline
\end{tabular}

phosphorous content of the various fire retardant finishes were assessed. It was not surprising that distilled water, maleic acid and acrylic acid recipes exhibited no phosphorous content. Highest phosphorus content was achieved for $40 \%$ Pyrovatex treated fabric. Normally, $17,000 \mathrm{ppm}$ is considered enough for imparting fire retardancy. The best recipe of maleic acid, DAHP, catalyst and initiator exhibited good phosphorous content of $31,350 \mathrm{ppm}$ demonstrating the effectiveness of the finish (table 9).

The development of formaldehyde free fire retardant was the basic purpose of this research, therefore, formaldehyde content of the various finished fabric was assessed. Pyrovatex treated fabric exhibited the formaldehyde content confirming the presence of toxic formaldehyde in the treated fabric. However, no formaldehyde was detected in any of the fabric treated with maleic acid, acrylic acid and DAHP combination, thus confirming that the newly developed recipes are completely formaldehyde free (table 10).

\section{Surface morphology of finished cotton fabric}

The surface of the control cotton fabric was smooth and clean as evident from the image of scanning electron microscope (SEM), (figure 3,a). However, there was confirmation of the coating on the surface of the cotton fabric when it was treated with recipe containing DAHP10\%, maleic acid $10 \%$, catalyst $8 \%$

Table 9

\begin{tabular}{|c|c|}
\hline \multicolumn{2}{|c|}{ PHOSPHOROUS CONCENTRATION IN VARIOUS FIRE RETARDANTS } \\
\hline Item Name & Concentration of phosphorous (ppm) \\
\hline Distilled water & 0 \\
\hline Maleic acid 10\% & 0 \\
\hline Acrylic acid 10\% & 0 \\
\hline DAHP 10\% & $27,367.2$ \\
\hline Pyrovatex 20\% & $17,689.7$ \\
\hline Pyrovatex 40\% & $43,344.8$ \\
\hline $\begin{array}{c}\text { Maleic acid } 10 \%+\text { DAHP } 10 \%+\text { SHP } 8 \%+\mathrm{K}_{2} \mathrm{~S}_{2} \mathrm{O}_{8} 0.2 \% \text { polymerized } \\
\text { at } 120^{\circ} \mathrm{C} \text { under nitrogen atmosphere }\end{array}$ & $31,350.72$ \\
\hline $\begin{array}{c}\text { Acrylic acid } 10 \%+\text { DAHP } 10 \%+\text { SHP } 8 \%+\mathrm{K}_{2} \mathrm{~S}_{2} \mathrm{O}_{8} 0.2 \% \text { polymerized } \\
\text { at } 90^{\circ} \mathrm{C} \text { under nitrogen atmosphere }\end{array}$ & $31,378.18$ \\
\hline
\end{tabular}




\begin{tabular}{|c|c|}
\hline \multicolumn{2}{|c|}{ FORMALDEHYDE CONTENT IN FABRIC } \\
\hline Item Name & Formaldehyde content in fabric (ppm) \\
\hline DAHP $10 \%$ & 0 \\
\hline Pyrovatex $20 \%$ & 32 \\
\hline Pyrovatex $40 \%$ & 41 \\
\hline $\begin{array}{c}\text { Maleic acid } 10 \%+\text { DAHP 10\% }+ \text { SHP } 8 \%+\mathrm{K}_{2} \mathrm{~S}_{2} \mathrm{O}_{8} 0.2 \% \text { polymerized } \\
\text { at } 120^{\circ} \mathrm{C} \text { under nitrogen atmosphere }\end{array}$ & 0 \\
\hline $\begin{array}{c}\text { Acrylic acid } 10 \%+\text { DAHP } 10 \%+\text { SHP } 8 \%+\mathrm{K}_{2} \mathrm{~S}_{2} \mathrm{O}_{8} 0.2 \% \text { polymerized } \\
\text { at } 90^{\circ} \mathrm{C} \text { under nitrogen atmosphere }\end{array}$ & 0 \\
\hline
\end{tabular}

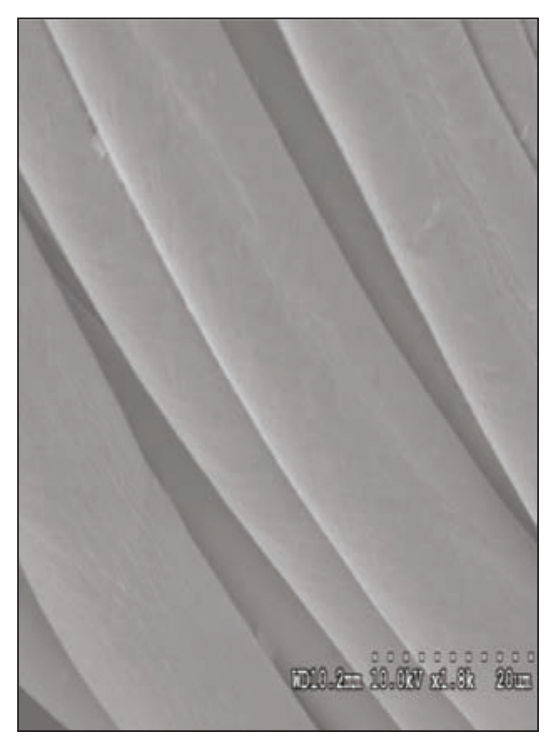

a

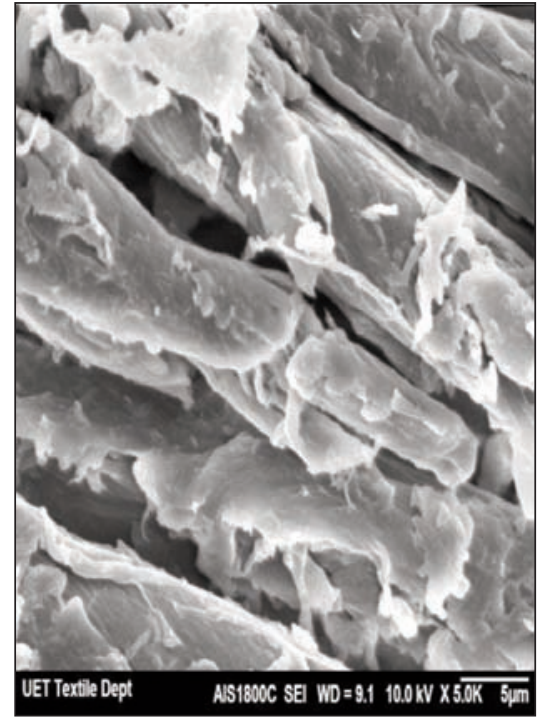

b

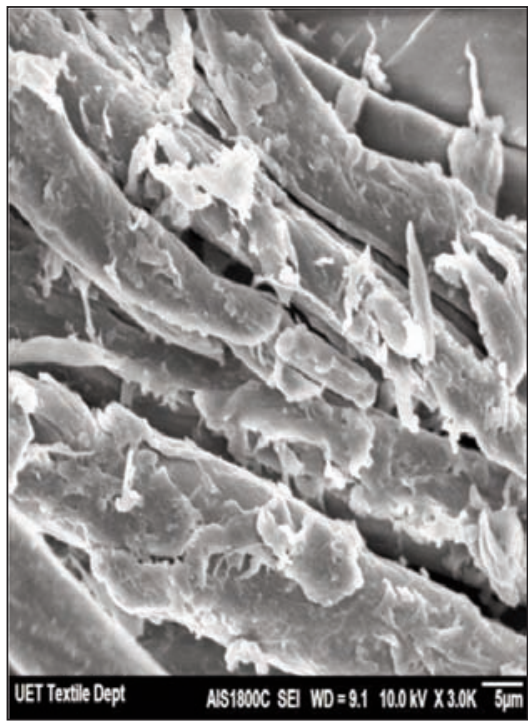

$c$

Fig. 3. SEM images of: $a$ - Untreated, $b$ - DAHP $10 \%+$ Maleic acid $10 \%+$ SHP $8 \%+\mathrm{K}_{2} \mathrm{~S}_{2} \mathrm{O}_{8} 0.2 \%$ at $120^{\circ} \mathrm{C}$ under nitrogen atmosphere, $c$ - DAHP $10 \%+$ Acrylic acid $10 \%+$ SHP $8 \%+\mathrm{K}_{2} \mathrm{~S}_{2} \mathrm{O}_{8} 0.2 \%$ at $90^{\circ} \mathrm{C}$ under nitrogen atmosphere

and initiator $0.2 \%$ (figure $3, b$ ). The figure 3,c exhibited the result when best recipe was applied on cotton fabric with respect to acrylic acid, DAHP, catalyst and initiator. Figures 3 , $b$ and $3, c$ confirmed the successful application of the both recipes onto the treated cotton fabric.

\section{Antimicrobial performance of finished cotton fabric}

It is quite well know that cotton

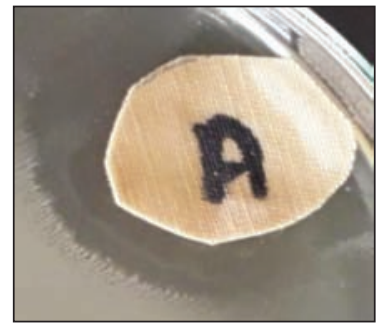

a

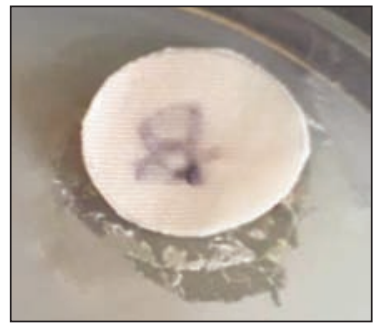

b

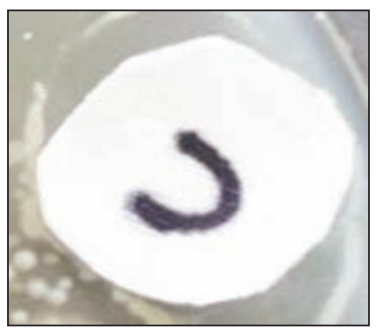

Fig. 4. a-DAHP 10\% + Acrylic acid 10\% + SHP $8 \%$ + Potassium per sufate $0.5 \%$ at $90^{\circ} \mathrm{C}$ under nitrogen atmosphere, $b-$ DAHP $10 \%+$ Maleic acid $10 \%+$ SHP $8 \%$ + Potassium per sulfate $0.2 \%$ at $120^{\circ} \mathrm{C}$ under nitrogen atmosphere, $c$ - untreated

is easily attacked by the microbes and same is demonstrated in our tests (figure 4,c). Both of the carboxylic acids; maleic acid and acrylic acid along with DAHP, catalyst and initiator treated fabric exhibited antimicrobial properties and clear zone of inhabitation of $0.20 \mathrm{~mm}$ and 0.82 $\mathrm{mm}$ respectively.

\section{CONCLUSION}

Halogen and formaldehyde free flame retardant have been synthesized by using the diammonium hydrogen phosphate and carboxylic acids like maleic acid and acrylic acid. The optimum results with respect to flame retardancy like limiting oxygen index and vertical burning were achieved when polymerization was carried out under nitrogen atmospherewith $\mathrm{K}_{2} \mathrm{~S}_{2} \mathrm{O}_{8}$ $0.2 \%$, sodium hypophosphite $8 \%$, diammonium hydrogen phosphate $10 \%$ along with maleic acid $10 \%$ and acrylic acid $10 \%$ at $120^{\circ} \mathrm{C}$ and $90^{\circ} \mathrm{C}$ respectively. There was also improvement in the burnt time of the smoldering cigarette test. 
Important additional properties of antimicrobial, crease recovery and better shrinkage control have been demonstrated by the optimum recipes. The successful synthesis and application of the newly recipes were confirmed by the FTIR analysis, phosphorous content and SEM analysis.

\section{ACKNOWLEDGEMENTS}

Authors are thankful to UET Lahore for funding this research project (No. ORIC-97/343).

\section{BIBLIOGRAPHY}

[1] Mohsin, M., Naveed, R., Qutab, H. G., Ahmad, S. W., Sarwar, N., Synthesis of halogen and formaldehyde free bio based fire retardant for cotton, In: Industria Textila, 2017, 68, 3, pp. 221-225

[2] Haynes, H. J. G., Fire loss in United States during 2015, In: National fire protection association, 2016

[3] Liu, Z., Xu, M., Wang, Q., Li, B., A novel durable flame retardant cotton fabric produced by surface chemical grafting of phosphorous - and - nitrogen containing compounds, In: Cellulose, 2017, 24, 9, pp. 4069-4081

[4] Gherasimescu, C., Butnaru, R., Leva, M., Mureşan, A., Manea, L. Z., Research regarding the optimization of flame retardant treatment for cellulose textile materials, In: Industria Textila, 2011, 62, 1, pp. 19-23

[5] Yasin, S., Behary, N., Giraud, S., Perwuelz, A., In situ degradation of organophosphorous flame retardant on cellulosic fabric using advanced oxidation process: A study on degradation and characterization, In: Polymer degradation and stability, 2016, 126, pp. 1-8.

[6] Salama, M., Bendak, A. Moller, M., Activating wool for flame-proof treatments with zirconium and titanium salts, In: Industria Textila, 2011, 62, 6, pp. 320-324.

[7] Mohsin, M., Ahmad, S. W., Khatri, A., Zahid, B., Performance enhancement of fire retardant finish with environment friendly bio cross-linker for cotton, In: Journal of cleaner production, 2013, 51, pp. 191-195

[8] Yang, C. Q., Wu, W., Xu, Y., The combination of a hydroxyl-functional organophosphorous oligomer and melamineformaldehyde as a retarding finishing system for cotton, In: Fire and materials, 2005, 29, pp. 109-120

[9] Wu, X., Yang, C. Q., Flame retardant Finishing of cotton fleece fabric, In: Journal of fire sciences, 2008, 26, pp. 351-368

[10] Samanta, A. K., Bagchi, A., Biswas, S. K., Fire retardant finishing of jute fabric and its thermal behavior using phosphorous and nitrogen based compound, In: Journal of Polymer Materials, 2011, 28, 149, pp. 149-169.

[11] Mohsin, M., Farooq, U., Ramzan, N., Rasheed, A., Ahmad, S., Ahsan, M., Softener impact on environment friendly low and zero formaldehyde cross-linker performance for cotton, In: Industria Textila, 2014, 65, pp. 134-139

[12] Mohsin, M., Ramzan, N., Ahmad, S. W., Afzal, A., Qutab, H. G., Development of environment friendly bio crosslinker finishing of silk fabric, In: Journal of natural fibers, 2015, 12, pp. 276-282

[13] Mohsin, M., Farooq, U., Raza, Z. A., Ahsan, M., Afzal, A., Nazir, A., Performance enhancement of wool fabric with environmentally friendly bio-cross-linker, In: Journal of cleaner production, 2014, 68, pp. 130-134

[14] Mohsin, M., Rasheed, A., Farooq, A., Ashraf, M., Shah, A., Environment friendly finishing of sulphur, vat, direct and reactive dyed cotton fabric, In: Journal of cleaner production, 2013, 53, pp. 341-347

[15] Mohsin, M., Sarwar, N., Ahmad, S., Rasheed, A., Ahmad, F., Afzal, A., Zafar, S., Maleic acid cross linking of C-6 fluorocarbon as oil and water repellent finish on cellulosic fabrics, In: Journal of cleaner production, 2016, 112, pp. $3525-3530$

[16] Salaun, F., Vroman, I., Influence of core materials on thermal properties of melamine - formaldehyde microcapsules, In: European polymer journal, 2008, 44, pp. 849-860

[17] Olsen, S. R., Cole, C. V., Watanabe, F. S., Dean, L., A., Estimation of available phosphorous in soils by extraction with sodium bicarbonate, 1954, U.S. Dep. Agric. Circ. 939, USA

\section{Authors:}

\section{HAJI GHULAM QUTAB ${ }^{1}$, MUHAMMAD MOHSIN², NAVEED RAMZAN ${ }^{3}$,} SYED WAQAS AHMAD ${ }^{1}$, ELENA CORNELIA MITRAN ${ }^{4}$

${ }^{1}$ Department of Chemical Engineering, UET Lahore, Faisalabad Campus, Pakistan

${ }^{2}$ Department of Textile Engineering, UET Lahore, Faisalabad Campus, Pakistan e-mail: mohsinmalikntu@yahoo.com

${ }^{3}$ Department of Chemical Engineering, UET Lahore, Main Campus, Pakistan

${ }^{4}$ The National Research and Development Institute for Textiles sand Leather, Bucharest, Romania e-mail: office@incdtp.ro

Corresponding author:

Dr. MUHAMMAD MOHSIN

e-mail: mohsinmalikntu@yahoo.com 


\section{Study on factors influencing customer leaving an apparel store without a purchase}

DOI: 10.35530/IT.070.04.1556

Studiu asupra factorilor care influenţează decizia de cumpărare a articolelor de îmbrăcăminte

În vânzarea cu amănuntul, mulți clienți părăsesc magazinul fără a face vreo achiziție din cauza diferiților factori. Un studiu detaliat a fost realizat pentru a înțelege factorii care influențează decizia clientului de a părăsi magazinul, fără o achiziție. În cadrul studiului, datele au fost colectate de la 1838 de clienți ai unui magazin de îmbrăcăminte și au fost analizate statistic folosind metoda de analiză a factorilor. Analiza factorilor a grupat 21 de variabile care influențează factori importanți, și anume: marfa, serviciile și personalul de vânzări. Printre acestea, motivele legate de marfă precum disponibilitatea produselor la modă, marca preferată și calitatea s-au dovedit a fi factori importanţi care influențează clienții. În cadrul studiului, au rezultat concluzii pentru comercianți. Studiul sistematic al factorilor care influențează clientul să renunțe la o achiziție a fost limitat la vânzarea cu amănuntul a articolelor de îmbrăcăminte. Prin urmare, lucrarea de față va fi foarte utilă pentru comercianții de îmbrăcăminte, cu scopul de a satisfice clienții într-o manieră mai eficientă.

Cuvinte-cheie: nemulțumirea clienților, renunțare, mărfuri, indisponibilitatea produsului, îmbrăcăminte

\section{Study on factors influencing customer leaving an apparel store without a purchase}

In retailing, many customers quit the store without a purchase due to various factors. In order to understand the influencing factors on customer leaving store without a purchase, a detailed study was conducted. For the study, data was collected from 1838 customers at an apparel store and statistically analyzed using factor analysis method was performed, to identify reasons for a customer leaving a store without a purchase. Factor analysis grouped 21 influencing variables into three major factors namely - Merchandise, Service, and Sales personnel. Among them, merchandise-based reasons like availability of fashionable products; preferred brand and quality were found to be a major factor influencing customers to leave the store without making a purchase. Based on the findings, implications for retailers were drawn. The systematic study of the factors influencing the customer to drop a purchase was limited in apparel retailing. Hence the present work will be very useful for the apparel retailers to satisfy customers in a better manner.

Keywords: customer dissatisfaction, defection, merchandise, product non-availability, apparel

\section{INTRODUCTION}

Apparel retailing in India predominantly was unorganized. In recent years, in apparel retailing due to the entry of Foreign Direct Investment and many organized players namely like Zara, H\&M, Reebok entering the business, apparel retail is transiting from unorganized to organized [1-2]. Thus a new challenge faced by Indian apparel retailer is to retain existing customers and withstand the tough competition by the organized new entrants. In order to retain an existing customer, the retailer needs to understand consumer purchase behavior and satisfy consumer needs, this scenario is same in various sectors of retailing too such as restaurants [3] and banking [4].

In all the sectors, researchers state that customer tastes are heterogeneous and individual customer needs vary from time to time, they also stress the need to understand customer behavior and satisfy them. Customer satisfaction is one of the key factors, as satisfied customers are likely to recommend to five or six people, while dissatisfied ones have a tendency to share their experience with other ten people [5]. Some studies [6] pointed out that retailers instead of spending heavily on new customers can work a strategy to retain existing customers which can increase the footfall conversion rate i.e., the ratio of a number of customers making a purchase versus the number of customers walk-in. In order to increase the footfall conversion rate retailers can introduce loyalty programs, understanding existing customers want etc. Compared to other retail sectors, footfall conversion rate is very less in apparel retailing. A current study [7] has documented the effect of traffic on conversion rate in apparel.

In apparel retailing, few research works have been carried out to understand customer-purchasing behavior. Current studies [8-9] have investigated and revealed that service, merchandise, value for money, location, staff are the factors influencing the store choice among Indian apparel shoppers in single branded and multi-branded store. The importance of store image attributes on consumer purchase behavior was studied by specialists [10]. In their study, the results showed that merchandise and clientele were highly important dimensions that affect store image. Studies [11-13] have analyzed the effect of store patronage customer satisfaction on consumer purchase behavior. Their study suggests that factors like 
service, product selection, brand, assortment and quality have a high influence on consumer purchase behavior. Authors [14] studied the major influencing factors for customers satisfaction and loyalty and found that trust has a positive effect on satisfaction and loyalty.

The behavior of consumers when their expected product is not available in the store was thoroughly studied by specialists [15]. Their study resulted that customer reacts by switching store or quitting or canceling the purchase, due to non-availability of their expected product in the store. These reactions by the customers lead to loss to the retailers [16]. A 5 percent reduction in the customer defection rate can increase profits by 25 to 85 percent, depending on the industry [17].

From the above literature on apparel retailing it is understood that though there are various studies to understand customer patronage, service quality, store image, customers reactions to non-product availability but there are very few [18] or rather no systematic study in apparel retailing that integrated study on merchandise/assortment based factors affecting consumer behavior reactions and reasons from the retailer for such situations.

In this context, this study aims to study the factors influencing customer no purchase decision. And also tries to identify reasons from the retailer's side on why that problem has happened. Thus, a retailer can identify reasons for the customer no purchase decision and also find out the reason from the retailer's side and curb that activity or improve certain services to avoid customer attrition.

\section{MATERIAL AND METHODS}

A questionnaire was designed and validated by [19] was used to collect data on consumer purchase behavior. Primarily the questionnaire was framed to analyze customers who buy, who do not buy, and who are browsers in the chosen retail store. The variables which affect the consumer purchase behavior are given in table 1 .

Another questionnaire which was developed and validated by authors [20] was used in the study to understand the reasons from the retailer for product nonavailability.

Store profile: The study was carried out in one reputed apparel retailer in Chennai, a metropolitan city, where heterogeneous customers shop. The store area is 11500 sq.ft, it caters to Men's, Women's, and Kids wear. The survey was carried out in the month of October because, in Chennai, it is the time when people tend to shop more apparel for the festival. The survey was carried out continuously for 30 days in all working hours from 10.00 am to $8.00 \mathrm{pm}$ of the day.

Survey: Primary data is collected using questionnaire by conducting store exit survey on all working hours of the day and all days of a week to have a full representation of the population. Respondents were chosen based on the systematic selection i.e. every

\begin{tabular}{|c|l|}
\hline \multicolumn{2}{|c|}{ STUDIED VARIABLES } \\
\hline \multicolumn{1}{|c|}{ Vable 1} \\
\hline SI. no. & \multicolumn{1}{|c|}{ Variables } \\
\hline 1 & Fashion garments \\
\hline 2 & Store personnel fast in service \\
\hline 3 & Branded merchandise \\
\hline 4 & Sstore personnel polite \& friendly \\
\hline 5 & Merchandise quality \\
\hline 6 & Waiting time \\
\hline 7 & Variety \\
\hline 8 & Checkout payment \\
\hline 9 & Guarantee \\
\hline 10 & Operating hours are not convenient \\
\hline 11 & Pricing \\
\hline 12 & Practical \& illogical shelf layout \\
\hline 13 & Competitive pricing \\
\hline 14 & Store temperature \\
\hline 15 & Coordinating merchandise \\
\hline 16 & Elevator \\
\hline 17 & Size \\
\hline 18 & Sales promotion \\
\hline 19 & Preferred color \\
\hline 20 & Adjustments \\
\hline 21 & Store personnel understanding needs \\
\hline
\end{tabular}

fifth customer was who exit the retail store was surveyed. The efficiency of the questionnaire was also tested using the response rate. Each day after the customer survey was over, the product which the customers expected to purchase but did not make a purchase were discussed with the store manager. For every product, the store manager gave the reason for product non-availability at that time.

Data Analysis: The primary data collected through survey were analyzed using factor analysis to understand the factors influencing consumer-purchasing behavior. SPSS was used to perform factor analysis. Respondents' demographics were also analyzed. The data on respondents who buy, who do not buy, who came for browsing was also analyzed.

\section{RESULTS AND DISCUSSION}

Response rate: The response rate for the survey is shown in table 2. From the table, it can be observed that among 1838 customers approached for the survey only 1665 accepted to respond which is $90.53 \%$. This indicates a good response rate. Further, from the table 2, it can be observed that out of 1665 respondents, 442 respondents did not make purchase their preferred item which is around $27 \%$. The intentions of respondents who do not purchase their preferred products were analyzed from the questionnaire and are given in table 3 . The five intentions mentioned in table 3 were switch store, postpone, item switch, cancel and brand switch. Out of 442 respondents, around $68 \%$ opted to switch store, $22 \%$ opted to 
postpone, $8 \%$ switched their item, i.e. instead of buying their most preferred product they bought some other product, $1 \%$ cancelled their purchase i.e they decided not to buy and $1 \%$ switched from their preferred brand to another brand, because they could not find their brand. From the above analysis, it is very clear that switching store gained higher value followed by postponing the purchase, item switch, canceling the purchase, and switching the brand. This $68 \%$ is a higher value, which could lead to a loss. This may be due to the fact that the respondents have a choice of finding another retailer to make their purchase. In this condition, the retail store must understand the needs of the consumer and satisfy the customers. The other $22 \%$ which opted to postpone may come to the same store later or may differ their purchase, which is also a loss, however only $8 \%$ of the respondents are ready to switch their item which is not a loss to the retailer, but the proportion is very less. Hence in the retailing process, customers have choices to get their products from their competitors; retailers must understand customers' needs and retain their customers.

That is they have gained $68 \%$ and $22 \%$ respectively, this indicates that the retailer must understand and satisfy the needs of the customers. Otherwise, this will become a big loss for the retailer, as $68 \%$ of customers who could not buy their product are switching store, i.e. they buy immediately from a competitor, and this will also spoil the retailer's reputation through bad word of mouth.

\begin{tabular}{|l|c|}
\hline \multicolumn{2}{|c|}{ RESPONSE RATE } \\
\hline \multicolumn{2}{|c|}{ Respo 2 } \\
\hline No. of customers approached & $\begin{array}{c}\text { Number of } \\
\text { respondents }\end{array}$ \\
\hline No. of respondents accepted to answer & 1838 \\
\hline No. of respondents without a purchase & 1665 \\
\hline
\end{tabular}

\begin{tabular}{|l|c|c|}
\hline \multicolumn{2}{|c|}{ STUDIED CUSTOMER INTENTION } \\
\hline \multicolumn{1}{|c|}{ Customer intention } & $\begin{array}{c}\text { Number of } \\
\text { respondents }\end{array}$ & $\begin{array}{c}\text { Frecvency } \\
\text { (\%) }\end{array}$ \\
\hline Switch store & 298 & 68 \\
\hline Postpone & 98 & 22 \\
\hline Item switch & 37 & 8 \\
\hline Cancel & 5 & 1 \\
\hline Brand switch & 4 & 1 \\
\hline $\begin{array}{l}\text { Total no. of respondents } \\
\text { without a purchase }\end{array}$ & 442 & 100 \\
\hline
\end{tabular}

Influential factors: This analysis investigates why the customer leaves the store empty-handed. The factor analysis grouped the 21 variables into three major factors. Among these three factors, factor 1 has the effect up to $27.68 \%$, factor 2 has an effect up to $9.9 \%$ and factor 3 also has an effect up to $9.5 \%$, whose Eigen values were greater than 1.

The factor analysis grouped 21 variables into 3 factors based on factor loading. In case of factor one, the variables such as current fashion goods, availability of size, color, brand, coordinates, quality of the merchandise, variety, guarantee and appropriate pricing resulted with higher loading ranges between 0.750 and 0.432 . It represents that these variables come from this factor 1 have a high influence on customer leaving the store empty-handed. And these variables are all related to merchandise and are termed as merchandise. Similarly, the factor 2 and 3 were termed as sales person and service.

Table 4

\begin{tabular}{|l|c|c|c|}
\hline \multicolumn{4}{|c|}{ ROTATED COMPONENT MATRIX } \\
\hline \multirow{2}{*}{ Items } & \multicolumn{3}{c|}{ Factors loadings } \\
\hline & 1 & 2 & 3 \\
\hline Fashion & 0.458 & & \\
\hline Brand & 0.432 & & \\
\hline Quality & 0.750 & & \\
\hline Variety & 0.678 & & \\
\hline Guarantee & 0.557 & & \\
\hline Price & 0.487 & & \\
\hline Competitor & 0.464 & & \\
\hline Coordinate & 0.584 & & \\
\hline Size & 0.492 & & \\
\hline Colour & 0.691 & & \\
\hline Understand & & 0.798 & \\
\hline Fast & & 0.842 & \\
\hline Polite & & 0.764 & \\
\hline Wait & & 0.623 & \\
\hline Payment & & & 0.735 \\
\hline Hours & & & 0.538 \\
\hline Layout & & & 0.609 \\
\hline Temperature & & & 0.439 \\
\hline Elevator & & & 0.654 \\
\hline Promo & & & 0.505 \\
\hline Adjustments & & & \\
\hline
\end{tabular}

Among the 3 factors, factor 1 has the highest value i.e. $27.68 \%$. Therefore, this retailer should mainly concentrate on factor 1 , the customer's reasons to switch store are major because of merchandise. From this table it is also clear that customers just do not purchase the available product, they are very smart, knowledgeable, and they analyze before a purchase. Thus, the study points out that merchandise is a most influencing factor for a customer leaving the storeempty-handed along with sales personnel and service. This accounts for $9.905 \%$ and 9.517\% respectively.

The Cronbach alpha an indicator of internal consistency was calculated as 0.785 for the 21 items, thus indicating a high degree of internal consistency. 
Table 5 also attributed. This also caused problems like shelf not being refilled on time. Thus, the table 5 clearly points out the retailer's reasons for a customer leaving the store without a purchase and a major reason is attributed to inefficient sales forecast.

\section{CONCLUSION}

Customers' leaving the store empty-handed was thoroughly studied in this study. From this study it was observed that $26.47 \%$ quit store without making a purchase, retailers should address to improve the $\%$ of profit and positive word of mouth. Merchandise based factors were the major factor cited by the respondents. From another survey for the retailers, the reasons for product non-availability was also studied and the major reason identified was inefficient sales forecast, i.e it can be attributed to lack of understanding of what the customer want. So retailers can make use of these kinds of the survey and take corrective actions to satisfy the customer and improve the conversion rate. This study is not void of limitations, as mentioned earlier, the study does not include other variables like personal reasons for leaving a store without a purchase. The cumulative \% accounted for only 47.107 and the remaining variables were not found to have a major influence.

\section{BIBLIOGRAPHY}

[1] Fatima, D., Impact of organised retailing on unorganised retailing in India 2015, 2013, shodhganga.inflibnet.ac.in/.../ 1/dinar\%20fatima_formatted_full_thesis.pdf

[2] Srivastava, R.K., Changing retail scene in India, In: Int J Retail Distrib Manag, 2008, 36, pp. 714-721, doi:https://doi.org/10.1108/09590550810890957

[3] Josiam, B.M., Malave, R., Foster, C., Baldwin W., Assessing quality of food, service and customer experience at a restaurant: the case of a student-run restaurant in the USA, Hosp Mark Consum Behav Creat Memorab Exp 2017

[4] Van Huy, L., Long, P., O'Connor, A., Tuyen, P.D., The development and measurement of a Customer Satisfaction Index (E-CSI) in electronic banking: An application to the Central Vietnam Region, In: Int J Strategy Decis Sci, 2017, 8, pp. 45-58, doi:10.4018/IJSDS.2017070102

[5] Zairi, M., Managing customer dissatisfaction through effective complaints management systems, In: TQM Mag, 2000, 12, pp. 331-337. doi:10.1108/09544780010341932

[6] Gallo, A., The value of keeping the right customers, In: Harv Bus Rev, 2014, 29

[7] Perdikaki, O., Kesavan, S., Swaminathan, J.M., Effect of traffic on sales and conversion rates of retail stores, In: Manuf Serv Oper Manag, 2012, 14, pp. 145-162, doi:10.1287/msom.1110.0356

[8] Basu, R., Guin, K.K., Sengupta, K., Do apparel store formats matter to Indian shoppers?, In: Int J Retail Distrib Manag, 2014, 42, pp. 698-716, doi:10.1108/IJRDM-03-2013-0065

[9] Tripathi, G., Dave, K., Store format choice and relationship quality in apparel retail: A study of young and earlymiddle-aged shoppers in New Delhi region, In: J Retail Consum Serv, 2013, 20, pp. 479-487, doi:https://doi.org/10.1016/j.jretconser.2013.04.003

[10] Van Noordwyk, H. S. J., Du Preez, R., Visser, E. M., Importance of apparel store image attributes: Perceptions of female consumers, In: SA J Ind Psychol, 2006, 32, pp. 49-62

[11] Pan, Y., Zinkhan, G. M., Determinants of retail patronage: A meta-analytical perspective, In: J Retail, 2006, 82, pp. 229-243, doi:10.1016/j.jretai.2005.11.008

[12] Fernie, J., Corcoran, L., Responses to out-of-stocks and on-shelf availability in UK fashion retailing, In: Int Rev Retail Distrib Consum Res, 2011, 21, pp. 309-322, doi:10.1080/09593969.2011.588715

[13] Popa, A., Pelau, C., Differences in the clothing brand perception depending on generation, In: Industria Textila, 2016, 67, 4, p. 260

[14] Hui, S. L., Yee, R. W. Y., Relationship among interpersonal relationship, customer satisfaction and brand loyalty in Fashion Retailing Industry, In: Res J Text Appar, 2015, 19, pp. 65-72, doi:10.1108/RJTA-19-01-2015-B007

[15] Campo, K., Gijsbrechts, E., Nisol, P., Towards understanding consumer response to stock-outs, In: J Retail, 2000, 76, pp. 219-242

[16] Battista, C., Falsini, D., Scarabotti, I., Schiraldi, M. M., Quantifying shelf-out-of-stock in fashion \& apparel retail stores, In: Proc. Conf. "Breaking Barriers Res. Ind., 2011 
[17] Matzler, K., Mooradian, T. A., King, L., Linder,A., Converting browser to buyers: an approach to measure and increase conversion rates in retailing, In: Innov Mark, 2010, 6, pp. 34-38

[18] Balakrishnan, R., A study of non conversion of customer footfall at Marks \& Spencer's (Mary St. Dublin), Dublin Business School, 2007

[19] Sundararaman, B., Ramalingam, N., Development and validation of a survey instrument to understand the factors influencing customer-leaving store empty-handed, In: TAGA, 2018, 14, pp. 1764-1776

[20] Vasconcellos, L. H. R., Sampaio, M., The stockouts study: an examination of the extent and the causes in the São Paulo supermarket sector, In: BAR-Braz Adm Rev, 2009, 6, pp. 263-79

\section{Authors: \\ SUNDARARAMAN BANUMATHY ${ }^{1}$, RAMALINGAM NEELAKANDAN²}

${ }^{1}$ Department of Apparel and Fashion Design, PSG College of Technology, Peelamedu, Coimbatore 641004, India e-mail: mailbanu@rediffmail.com

${ }^{2}$ Department of Textile Technology, Anna University, Guindy, Chennai 600 025, India,

e-mail: neelakandanr@annauniv.edu

Corresponding author:

SUNDARARAMAN BANUMATHY

e-mail: mailbanu@rediffmail.com 


\section{Effect of coating ratio and weft density on some physical properties of upholstery fabrics}

DOI: 10.35530/IT.070.04.1695

Influenţa raportului de acoperire și a desimii în bătătură asupra proprietăților fizice ale țesăturilor pentru tapițerie

Această lucrare își propune să analizeze influenţa raportului de acoperire $\left(\mathrm{g} / \mathrm{m}^{2}\right)$ și a desimii în bătătură (fire de bătăură/cm) asupra unor proprietăți fizico-mecanice ale țesăturilor acoperite, precum rezistenţă la abraziune, pilingul, permeabilitatea la aer și rezistența la alunecarea firelor la cusături în direcția urzelii și bătăturii. În acest studiu, au fost realizate țesături pentru tapițerie din 100\% poliester la trei niveluri de desime în bătătură, cu 5, 7 și 9 fire de bătătură/cm pe mașina de țesut Dornier, cu aceeași desime a firelor de urzeală de 8 fire de urzeală/cm. Trei raporturi de acoperire au fost selectate de $30 \mathrm{~g} / \mathrm{m}^{2}, 60 \mathrm{~g} / \mathrm{m}^{2}$ și $90 \mathrm{~g} / \mathrm{m}^{2}$ pentru aplicarea substanței de acoperire cu spumă acrilică pe țesăturile pentru tapițerie. Au fost realizate 18 tipuri de țesături acoperite, în procese de producție controlate, iar jumătate dintre acestea au fost supuse unui proces suplimentar de interțesere, înainte de acoperire. Țesăturile pentru tapițerie cu legătură pânză au fost evaluate în ceea ce privește rezistenţa la abraziune, pilingul, permeabilitatea la aer și rezistenţa la alunecarea firelor la cusături în direcția urzelii și bătăturii. Conform rezultatelor testelor privind pilingul țesăturilor pentru tapițerie care au fost expuse numai procesului de acoperire, acestea au fost satisfăcătoare în comparație cu grupurile de țesături acoperite şi interțesute. Conform testului ANOVA în ambele sensuri, raportul de acoperire a fost un factor semnificativ pentru țesăturile acoperite, în timp ce raportul de acoperire, desimea în bătătură și interacțiunea acestora au fost factori nesemnificativi pentru țesăturile pentru tapițerie interțesute şi acoperite, în ceea ce privește rezultatele rezistenţei la abraziune si pierderea de masă a țesăturilor (\%). Proprietățile de permeabilitate la aer şi rezistenţa la alunecare a firelor la cusături în direcția bătăturii au fost semnificativ influenţate de desimea în bătătură, de raportul de acoperire și de interacțiunea acestora între grupurile de țesături acoperite interțesute. Desimea în bătătură a fost un factor nesemnificativ de 0,05 pentru valorile rezistenței la alunecare a firelor la cusături în direcția urzelii, între grupurile de țesături acoperite.

Cuvinte-cheie: desimea în bătătură, raportul de acoperire, țesătură pentru tapițerie, permeabilitatea la aer, rezistenţa la alunecarea firelor la cusături

\section{Effect of coating ratio and weft density on some physical properties of upholstery fabrics}

This paper aims to examine the effects of coating ratio $\left(\mathrm{g} / \mathrm{m}^{2}\right)$ and weft density $($ picks $/ \mathrm{cm})$ on some mechanical properties of coated fabrics such as abrasion, pilling, air permeability and seam slippage strength in warp and weft direction of fabrics. In this research, $100 \%$ Polyester upholstery fabrics were woven at three levels of weft density as 5 , 7 and 9 picks $/ \mathrm{cm}$ on Dornier weaving machine with the same warp density of 8 ends $/ \mathrm{cm}$. Three coating ratios were selected as $30 \mathrm{~g} / \mathrm{m}^{2}, 60 \mathrm{~g} / \mathrm{m}^{2}$ and $90 \mathrm{~g} / \mathrm{m}^{2}$ for applying acrylic foam coating substance to the upholstery fabrics. 18 different coated fabrics were produced under controlled production processes where half of them were sent to an additional process of needle punching before coating and half of them were not. Plain type upholstery fabrics were evaluated in terms of abrasion, pilling grade, air permeability and seam slippage strength forces in warp and weft directions. According to test results, pilling results of upholstery fabrics which were exposed to only coating process were more satisfying comparing to coated needle punched fabric groups. According to two-way ANOVA test; coating ratio was a significant factor among the coated fabrics whereas coating ratio, weft density and their interaction were insignificant factors among the coated needle punched upholstery fabrics with respect to abrasion results in terms of fabrics' mass loss (\%). Air permeability property, seam slippage strength in weft direction were significantly affected by the weft density, coating ratio and their interaction among the coated and coated needle punched fabric groups. Weft density was an insignificant factor for the seam slippage strength values in warp direction among the coated fabric groups at significance level of 0.05 .

Keywords: weft density, coating ratio, upholstery fabric, air permeability, seam slippage

\section{INTRODUCTION}

Discovery of resin and polymeric materials and the developments in the chemical industry resulted in new products with different properties and usage areas. It is aimed to add the chemical finish to fabric in coating while the purpose is to join two textiles into one structure with the chemical adhesive in lamination. Coated or laminated fabrics have several end-uses such as aggrotech, hometech, medtech, protective clothes... etc. Knitted and non-woven structures are especially useful for coating and laminating but when strength and dimensional stability are required, woven fabrics are preferred. Coating and lamination technology provides products for automotive air bags, footwear, interlinings, upholstery, hats, labels, umbrellas, adhesive tapes, rainwear, 
protective clothing, artificial leather articles, window blinds, tents, sleeping bags, curtains, floor coverings, luggage, sails, mattress ticking, flexible fuel tanks, abrasive products, filter fabrics, geotextiles, hoses and many others. Fabric plays a major role for the final properties of the finished product. Yarn construction and fabric formation are influential factors in addition to chemical and physical properties of fibres. Fabric structure determines the degree of textile-finish interbonding as well as the final mechanical properties of the treated material. The chemicals used for coating and laminating are polymeric materials of natural or synthetic. These include natural and synthetic rubbers, polyvinyl chloride, polyvinyl alcohol, acrylic, phenolic resins, polyurethanes, silicones, fluoro chemicals, epoxy resins and polyesters. Additive formulations such as UV radiation, heat stabilizers, antioxidants, fillers to improve mechanical properties, fillers for cost management, FR chemicals, reinforcement fibres, and pigments may be applied to the fabric substrate in order to provide further features. There are different coating methods such as immersion coating, knife coating, transfer coating, kiss-roll rotating, metering road coating, gravure roll coating, screen coating, and curtain coating [1-4].

Rotary screen coating which will be mentioned in our experimental work below is the deposition of a coating material on a substrate through a mesh screen by squeezing [2]. The amount of coating (claimed between 5 and $500 \mathrm{~g} / \mathrm{m}^{2}$ ) is controlled by the screen mesh number, squeeze pressure, the angle between the squeeze blade and the screen and the viscosity of the coating fluid. An array of dots is pushed through the perforated screen by the squeegee bar inside the screen and by centrifugal force onto the fabric [1].

There are some early studies related to effect of coating process on some fabric properties. Wan and Stylios made a study related to effect of coating process on surface roughness of coated fabrics measured by Kawabata Evaluation System. The treatment temperature, gap spacing, coating speed and viscosity of the coating paste were selected for process parameters to be changed. Low surface roughness for coated fabrics could be obtained with the appropriate process parameters [5]. Some scholars also concluded that surface roughness is directly proportional with the coating thickness [6-7]. Twill weave cotton fabric that was coated with zinc oxide layer was investigated in terms of thermal comfort properties by using Permetest instrument [8]. Polyurethane (PU) and polyurethane/ silicone (PU/silicone) coated fabrics were produced and the effects of coating parameters such as coating mate- rial, coating technique and production parameters on sewing performance of the coated fabrics were analysed in another study [9]. Effects of same coating process parameters on two type cotton-based fabrics were investigated in order to evaluate some mechanical properties of the coated fabrics such as breaking strength, tearing strength, bursting strength and bending rigidity [10].

Apart from the early studies, foam technology was preferred in our study during coating instead of the wet processes where the reagent was applied to the fabric in the foam form in contrast to the conventional processes [11]. Foams applied in textile are generally dispersion foams which are produced by the introduction and mixing of gas from an external source into a liquid phase containing a surface-active agent as the foaming agent. Before the coating process, upholstery producers propose "needle punching process" in order to improve the seam slippage strength of coated upholstery fabrics. This process provides a fabric surface with protruding fibres. Since the casual influence of some processing parameters such as weft density, coating ratio $\left(\mathrm{g} / \mathrm{m}^{2}\right)$ is still not well understood, this research aims to contribute to the literature by investigating effect of coating ratio and weft density on abrasion, pilling, air permeability and seam slippage strength of the upholstery fabrics and also the effect of additional needle punching process before acrylic polymer foam coating.

\section{MATERIAL AND METHOD}

The same yarn of 1000 denier/516 filament air textured polyester was used as warp and weft yarns of upholstery fabrics. The plain woven fabrics having warp density of 8 warps $/ \mathrm{cm}$ and weft densities of 5-7-9 wefts/cm were woven on Dornier brand industrial weaving machine. After weaving process, half of the samples were sent to Dilo needle punching machine with 12 penetrations and 180 punch $/ \mathrm{cm}^{2}$ stroke frequency after weaving process. Needle punching was applied along the one side of woven fabrics. After needle punching process, all samples were foam coated with the acrylic binder ORGAL HC 50 FF by using Stork rotary screen machine (figure 1,a). A foam generator was used in order to apply the foam via a "closed" squeegee using wet add-on (figure 1,b). Three different coating ratios were selected as $30 \mathrm{~g} / \mathrm{m}^{2}, 60 \mathrm{~g} / \mathrm{m}^{2}$ and $90 \mathrm{~g} / \mathrm{m}^{2}$ in order to observe the

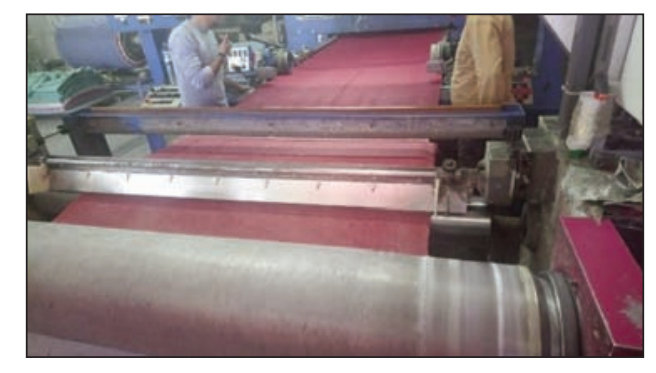

a

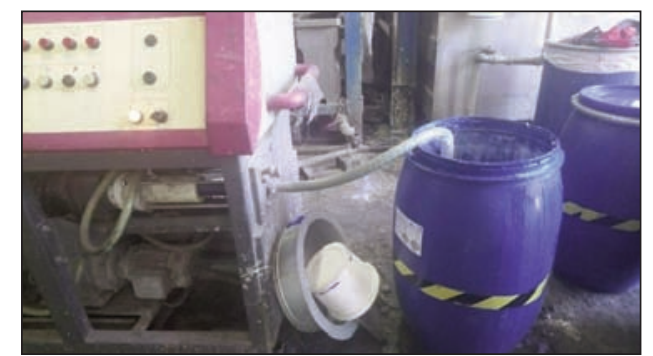

b

Fig. 1. $a$ - fabric coating with rotary screen technique; $b$ - foam generator 
Table 1

\begin{tabular}{|c|c|c|c|c|c|}
\hline \multicolumn{6}{|c|}{ EXPERIMENTAL DESIGN } \\
\hline $\begin{array}{l}\text { Fabric } \\
\text { code }\end{array}$ & $\begin{array}{c}\text { Fabric } \\
\text { weight } \\
\left(\mathrm{g} / \mathrm{m}^{2}\right)\end{array}$ & $\begin{array}{c}\text { Warp } \\
\text { density } \\
\text { (thread/ } \\
\mathrm{cm} \text { ) }\end{array}$ & $\begin{array}{c}\text { Weft } \\
\text { density } \\
\text { (thread/ } \\
\text { cm) }\end{array}$ & $\begin{array}{c}\text { Coating } \\
\text { ratio } \\
\left(\mathrm{g} / \mathrm{m}^{2}\right)\end{array}$ & Process \\
\hline C530 & 166.5 & 8 & 5 & 30 & \multirow{9}{*}{$\begin{array}{l}\text { foam } \\
\text { coating }\end{array}$} \\
\hline C560 & 180 & 8 & 5 & 60 & \\
\hline C590 & 221 & 8 & 5 & 90 & \\
\hline C730 & 192.7 & 8 & 7 & 30 & \\
\hline C760 & 212 & 8 & 7 & 60 & \\
\hline C790 & 234.5 & 8 & 7 & 90 & \\
\hline C930 & 212.7 & 8 & 9 & 30 & \\
\hline C960 & 240 & 8 & 9 & 60 & \\
\hline C990 & 258.8 & 8 & 9 & 90 & \\
\hline NC530 & 167.8 & 8 & 5 & 30 & \multirow{9}{*}{$\begin{array}{c}\text { needle } \\
\text { punching } \\
+ \text { foam } \\
\text { coating }\end{array}$} \\
\hline NC560 & 189 & 8 & 5 & 60 & \\
\hline NC590 & 199.2 & 8 & 5 & 90 & \\
\hline NC730 & 197.9 & 8 & 7 & 30 & \\
\hline NC760 & 219.5 & 8 & 7 & 60 & \\
\hline NC790 & 219.7 & 8 & 7 & 90 & \\
\hline NC930 & 223.7 & 8 & 9 & 30 & \\
\hline NC960 & 248.7 & 8 & 9 & 60 & \\
\hline NC990 & 249.5 & 8 & 9 & 90 & \\
\hline
\end{tabular}

effect of coating substrate amount on the woven fabrics' properties of pilling, abrasion, air permeability and sewing slippage strength. Coating speed in the machine was kept constant at $20 \mathrm{~m} / \mathrm{min}$ for all woven fabrics. Afterwards, coated fabrics were sent to drying at $125^{\circ} \mathrm{C}$ for 54 seconds in Brückner Stenter. The experimental plan is indicated in table 1.

Prior to testing of abrasion, pilling, seam slippage strength of woven fabrics and air permeability tests, all fabrics were conditioned for 24 hours in standard atmospheric conditions (at the temperature of $21 \pm 1$ ${ }^{\circ} \mathrm{C}$ and relative humidity of $65 \pm 2 \%$ ). The abrasion resistances of the fabrics were tested with Martindale Abrasion Tester according to ISO 12947-3:1998 standard [12] where the mass loss is determined as the difference between the sample mass values before and after abrasion cycles of 40,000 with the nominal pressure of $12 \mathrm{kPa}$. The cycles in which the first yarn break occurrence were also tried to be determined. However, there was not any yarn breakdown until 200,000 cycles due to the high tensile properties of upholstery fabrics made of textured polyester yarn with high breaking forces [13-14]. Pilling tests were also conducted on the same Martindale test equipment according to standard of 12945-2: 2000. Three samples were tested for each fabric type on James Heal Martindale tester. The pilling properties of the samples were evaluated by comparing their visual appearance with standard photographs. Samples were rated on a scale of 1 to 5 ( 1 for the worst, 5 for the best) [14]. Air permeability of upholstery fabrics was measured in a $20 \mathrm{~cm}^{2}$ test area at $200 \mathrm{~Pa}$ air pressure with test device of SDL ATLAS M021A according to EN ISO 9237 test standard [15]. Seam slippage is a kind of failure results from a yarn movement at either side of the seam creating a gap. The displacement of the yarns in fabric generates an opening in the fabric [16]. Rectangular specimens of $350 \mathrm{~mm}$ length and $100 \mathrm{~mm}$ width were prepared. 5 specimens $(350 * 100)$ with their long sides parallel to the weft of the fabric for determining warp slippage and with their long sides parallel to the warp of the fabric for determining the weft slippage according to ISO 13936-1: 2004 test standard by using Testometric $5 \mathrm{kN}$ device. The two force elongation curves were obtained from the unsewn and sewn sample and the force required to open the seam opening distance $(3 \mathrm{~mm})$ was determined by using the horizontal separation between the curves [17-18]

\section{Statistical analyses}

For interpreting the statistical significance of weft density and coating ratio on woven upholstery fabrics' properties such as abrasion in terms of mass loss (\%), air permeability $(\mathrm{mm} / \mathrm{s})$ and seam slippage strength in warp direction and weft direction; Randomized two-direction ANOVA was performed. SNK tests were conducted for the comparison of means of fabric mass loss (\%), air permeability $(\mathrm{mm} / \mathrm{sec})$ and seam slippage strength of the woven fabrics. The treatment levels in SNK tests were marked in accordance with the mean values and levels marked by different letter $(a, b, c)$ indicating the significant differences. The significance level $(\alpha)$ selected for all statistical tests in the study is 0.05 .

\section{RESULTS AND DISCUSSION}

\section{Pilling and abrasion results}

Pilling is caused by protruding fibres which entangle when a fabric is rubbed. The magnitude of the pilling depends upon the number and lengths of protruding fibres and the ease with which they can bend round one another [19]. Figure 2 illustrates the pilling values of upholstery fabrics after 5000 abrasion cycles. As it is observed there is not a prominent influence of weft density and the coating ratio $\left(\mathrm{g} / \mathrm{m}^{2}\right)$ on the pilling value of the fabrics. However, the fabrics' pilling grades deteriorated regarding to application of needle punching process before coating process. This may be attributed to the increment of the yarn hairiness owing

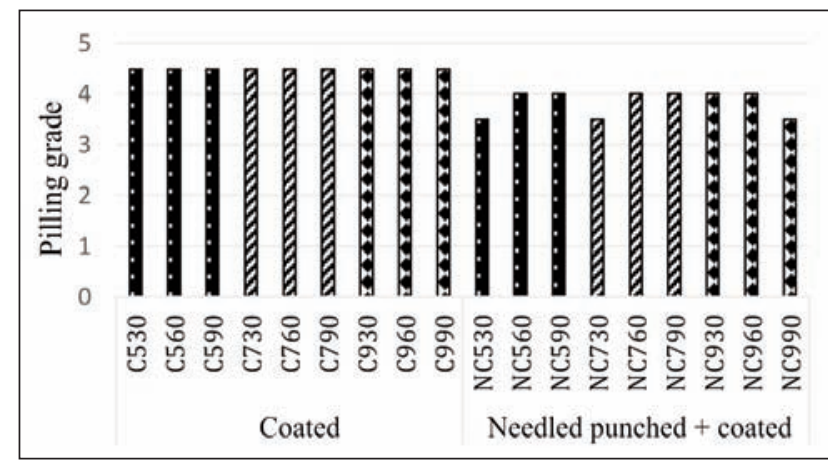

Fig. 2. Pilling grades 


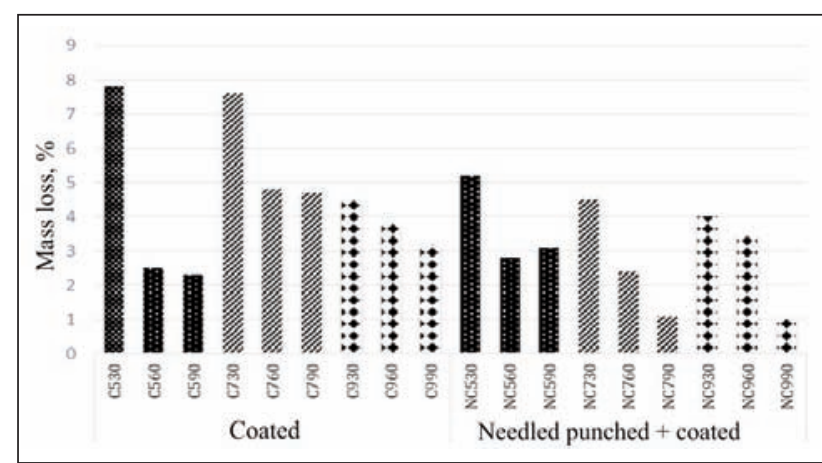

Fig. 3. Mass loss ratios (\%) of the fabrics

to the filament breakages during fabric needling which results with high pilling tendency.

Diagram of mass losses of 18 different fabrics is presented in figure 3 . According to figure 3 , maximum mass loss ratio $(7.8 \%)$ was obtained from C530 fabric variant whereas the minimum mass loss ratio (1\%) was obtained from NC990 fabric variant. In addition to this, there is a general decrement trend for the mass loss values of the fabric groups with the increased coating ratio. Needle-punching process slightly seems to be improving the abrasion properties of the fabrics in terms of mass losses (\%). This may be attributed to better efficiency of coating process applied to the needle punched fabrics where the protruding fibres are strongly coated. There is not a prominent trend for the mass loss ratios (\%) regarding to weft density considering all fabric groups.

Table 2 and table 3 indicate the ANOVA results and SNK results concerning the effect of coating ratio and weft density on mass loss of the fabrics. According to two-way completely randomized ANOVA (table 2), there were statistically significant differences (at significance level of 0.05 ) between the mass losses (\%) of fabrics treated at different coating ratio (\%) among the coated fabric groups without needle punching. However, weft density parameter, interaction of coating ratio $\left(\mathrm{g} / \mathrm{m}^{2}\right)$ and weft density parameter were not significant factors for the mass loss ratios (\%) of coated fabrics. Regarding to SNK test with respect to coating ratio (table 3 ), the highest mass loss $(4.5 \%)$ was obtained from the coated fabric groups treated with $30 \mathrm{~g} / \mathrm{m}^{2}$ coating ratio whereas the lowest mass loss ratio $(2.44 \%)$ was found among the fabrics treated with $90 \mathrm{~g} / \mathrm{m}^{2}$ coating ratio. This result may be attributed to the less yarn movement owing to the coating foam substance penetrating into the fabric resulting with lower mass loss (\%). It is generally stated that the ability of a fibre and also yarn to withstand repeated distortion influence the abrasion resistance [20].

\section{Air permeability results}

Figure 4 indicates the air permeability measurement results of woven fabrics. It is observed that coated needled punched fabrics revealed lower air permeability values comparing to their counterparts of coated variants. It is also understood that as the weft density

\begin{tabular}{|c|c|c|c|}
\hline & & & Table \\
\hline UNIVARI & $\begin{array}{l}\text { TTE TWO DI } \\
\text { FOR MA }\end{array}$ & $\begin{array}{l}\text { RECTION ANO } \\
\text { SS LOSS ( } \%)\end{array}$ & /A RESULTS \\
\hline Physica & property & $\begin{array}{c}\text { Mass losses } \\
\text { of coated } \\
\text { fabrics } \\
(\%)\end{array}$ & $\begin{array}{l}\text { Mass losses } \\
\text { of coated } \\
\text { needle } \\
\text { punched } \\
\text { fabrics }(\%)\end{array}$ \\
\hline Source & & Sig.(p) & Sig.(p) \\
\hline & $\begin{array}{l}\text { weft } \\
\text { density (D) }\end{array}$ & 0.70 & 0.09 \\
\hline Main effect & $\begin{array}{l}\text { coating } \\
\text { ratio }(R)\end{array}$ & $0.00^{*}$ & 0.15 \\
\hline Interaction & $D^{*} R$ & 0.40 & 0.69 \\
\hline
\end{tabular}

* Statistically important according to $\alpha=0.05$.

Table 3

EFFECT OF COATING RATIO ON MASS LOSS (\%) STUDENT-NEWMAN-KEULS (SNK)

\begin{tabular}{|c|c|c|}
\hline \multicolumn{2}{|c|}{ Parameter } & Only coated fabrics \\
\hline \multirow{3}{*}{ Coating ratio $\left(\mathrm{g} / \mathrm{m}^{2}\right)$} & 30 & $4.50 \mathrm{c}$ \\
\cline { 2 - 3 } & 60 & $4.07 \mathrm{~b}$ \\
\cline { 2 - 3 } & 90 & $2.44 \mathrm{a}$ \\
\hline
\end{tabular}

NOTE: The different letters next to the counts indicate that they are significantly different from each other at a significance level of $5 \%$.

of the fabrics increased, air permeability of the woven fabrics decreased considering the both groups which were only coated and coated needle punched. When the effect of applied coating ratio is evaluated, air permeability of all upholstery fabrics prominently decreased as the coating ratio increased from $30 \mathrm{~g} / \mathrm{m}^{2}$ to $90 \mathrm{~g} / \mathrm{m}^{2}$. According to two-way ANOVA, weft density, coating ratio and their interaction significantly influenced the air permeability of all produced woven fabrics (table 4). SNK test results also indicated that fabrics produced with different weft density and treated with different coating ratio $\left(\mathrm{g} / \mathrm{m}^{2}\right)$ possessed statically different air permeability values (table 5 ). Within the only coated fabric groups, the lowest air permeability value $(1390.22 \mathrm{~mm} / \mathrm{s})$ was obtained from the fabrics coated with the amount of $90 \mathrm{~g} / \mathrm{m}^{2}$ acrylic binder whereas the highest value $(1699.66 \mathrm{~mm} / \mathrm{s})$ was obtained from the coated fabric groups treated

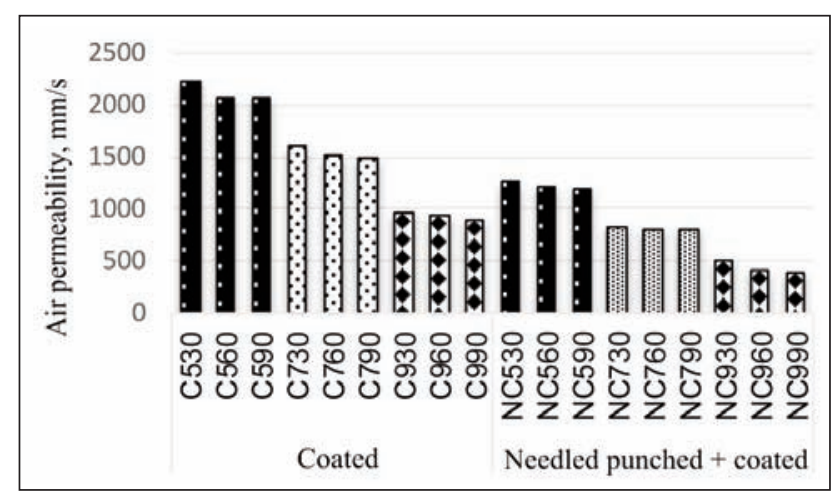

Fig. 4. Air permeability of the coated fabrics $(\mathrm{mm} / \mathrm{s})$ 


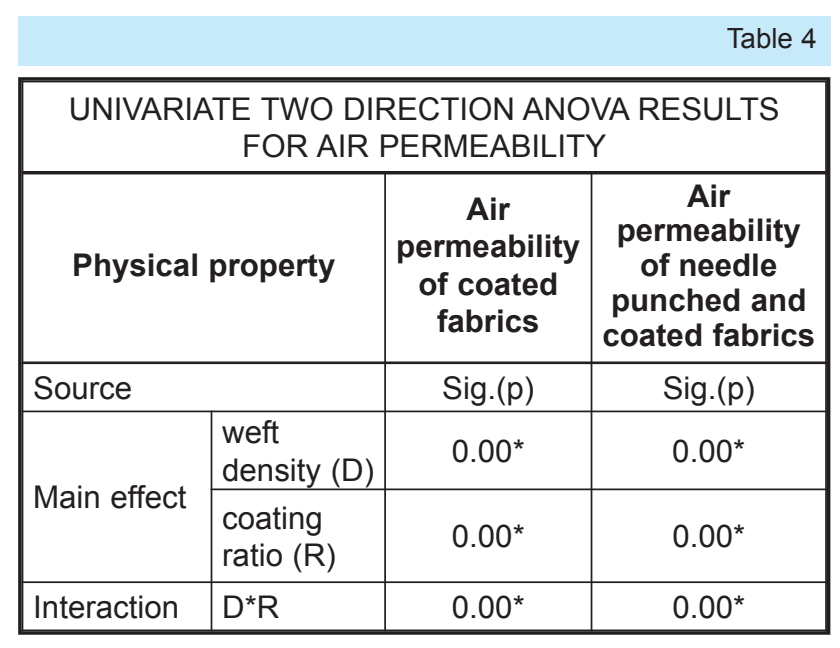

* Statistically important according to $\alpha=0.05$.

Table 5

EFFECT OF COATING RATIO AND WEFT DENSITY

ON AIR PERMEABILITY, STUDENT-NEWMAN-KEULS (SNK)

\begin{tabular}{|c|c|c|c|}
\hline \multicolumn{2}{|c|}{ Parameter } & $\begin{array}{c}\text { Coated } \\
\text { fabrics }\end{array}$ & $\begin{array}{c}\text { Coated } \\
\text { needle punched } \\
\text { fabrics }\end{array}$ \\
\hline \multirow{2}{*}{$\begin{array}{c}\text { Coating ratio } \\
\left(\mathrm{g} / \mathrm{m}^{2}\right)\end{array}$} & 30 & $1699.66 \mathrm{c}$ & $1025.6 \mathrm{c}$ \\
\cline { 2 - 4 } & 60 & $1498.88 \mathrm{~b}$ & $864 \mathrm{~b}$ \\
\hline \multirow{2}{*}{$\begin{array}{c}\text { Weft density } \\
(\mathrm{D})\end{array}$} & 90 & $1390.22 \mathrm{a}$ & $803.3 \mathrm{a}$ \\
\cline { 2 - 4 } & 7 & $1598.44 \mathrm{~b}$ & $863.44 \mathrm{~b}$ \\
\cline { 2 - 4 } & 9 & $971.55 \mathrm{a}$ & $510 \mathrm{a}$ \\
\hline
\end{tabular}

NOTE: The different letters next to the counts indicate that they are significantly different from each other at a significance level of $5 \%$.

with coating ratio of $30 \mathrm{~g} / \mathrm{m}^{2}$. The same trend was observed among the coated needle punched fabric groups. It was also observed that needle punching process led to decrement of air permeability values of upholstery fabrics. Depending on the weft density, there is a decrement trend for the air permeability of the coated fabrics as the weft density increased. As a summary of SNK table (table 5), the air permeability decreased with the increase in amount of acrylic binder at a constant weft density while the air permeability decreased with the increase of weft density at a constant coating ratio.

\section{Seam slippage strength}

Upholstery fabrics hence the seams are constantly under different kinds of stresses in different directions [21]. Figure 5

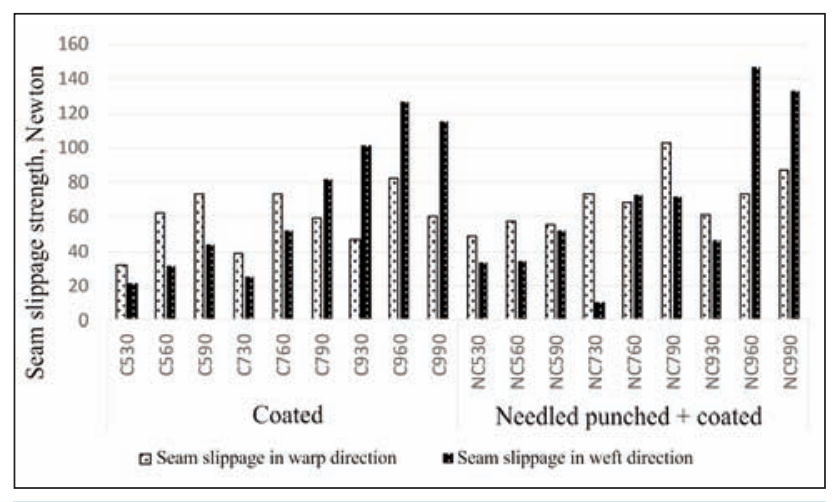

Fig. 5. Seam slippage force (Newton)

indicates the seam slippage force in warp and weft direction. There is a clear increment trend for the seam slippage force in warp direction within the fabric groups of C530, C560, C590 and NC930, NC960, NC990 as the applied coating ratio $\left(\mathrm{g} / \mathrm{m}^{2}\right)$ increased. Weft density increment generally resulted with better seam slippage results both in warp and weft directions (figure 5). Our result was also supported with Yıldırım et al.'s study in which the author established a non-linear regression model for the seam slippage values and emphasized that weft density played a major role in the seam slippage behaviour [22]. Additionally, two-way ANOVA test was performed in order to evaluate the effect of coating ratio $\left(\mathrm{g} / \mathrm{m}^{2}\right)$ and weft density on the slippage strength values in warp and weft directions (table 6). Considering the coated fabric groups without needle punching process, coating ratio had significant effect on seam slippage strength (newton) in warp and weft directions at significance level of 0.05 . However, weft density did not statistically influence the seam slippage strength in warp direction. Additionally, interaction of coating ratio and weft density had significant effect on the upholstery fabrics' seam slippage strength in warp and weft direction. Considering the coated needle punched fabrics, there was a significant difference of seam slippage values in warp and in weft direction of the fabrics produced at different weft densities and

\begin{tabular}{|c|l|c|c|c|c|}
\hline \multicolumn{7}{|c|}{$\begin{array}{r}\text { UNIVARIATE TWO DIRECTION ANOVA RESULTS } \\
\text { FOR SEAM SLIPPAGE STRENGTH }\end{array}$} \\
\hline \multirow{2}{*}{ Parameter } & \multicolumn{2}{|c|}{ Only coated fabrics } & \multicolumn{2}{c|}{$\begin{array}{c}\text { Coated needle } \\
\text { punched fabrics }\end{array}$} \\
\hline \multirow{2}{*}{ Source } & $\begin{array}{c}\text { Seam slippage } \\
\text { strength in } \\
\text { warp direction }\end{array}$ & $\begin{array}{c}\text { Seam slippage } \\
\text { strength in } \\
\text { weft direction }\end{array}$ & $\begin{array}{c}\text { Seam slippage } \\
\text { strength in } \\
\text { warp direction }\end{array}$ & $\begin{array}{c}\text { Seam slippage } \\
\text { strength in } \\
\text { weft direction }\end{array}$ \\
\cline { 3 - 6 } & Sig.(p) & Sig.(p) & Sig.(p) & Sig.(p) \\
\hline \multirow{2}{*}{ Main effect } & $\begin{array}{l}\text { weft } \\
\text { density (D) }\end{array}$ & 0.07 & $0.00^{*}$ & $0.00^{*}$ & $0.00^{*}$ \\
\cline { 2 - 6 } & $\begin{array}{l}\text { coating } \\
\text { ratio (R) }\end{array}$ & $0.00^{*}$ & $0.00^{*}$ & $0.00^{*}$ & $0.00^{*}$ \\
\hline Interaction & $D^{*} R$ & $0.00^{*}$ & $0.00^{*}$ & $0.02^{*}$ & $0.00^{*}$ \\
\hline
\end{tabular}

* Statistically important according to $\alpha=0.05$. 
SEAM SLIPPAGE STRENGTH, SNK RESULTS

\begin{tabular}{|c|c|c|c|c|c|}
\hline \multicolumn{2}{|c|}{} & \multicolumn{2}{|c|}{$\begin{array}{c}\text { Seam slippage strength in } \\
\text { warp direction }\end{array}$} & \multicolumn{2}{|c|}{$\begin{array}{c}\text { Seam slippage strength in } \\
\text { weft direction }\end{array}$} \\
\cline { 2 - 6 } \multicolumn{2}{|c|}{ Parameter } & $\begin{array}{c}\text { Coated } \\
\text { fabrics }\end{array}$ & $\begin{array}{c}\text { Coated } \\
\text { needle punched } \\
\text { fabrics }\end{array}$ & $\begin{array}{c}\text { Coated } \\
\text { fabrics }\end{array}$ & $\begin{array}{c}\text { Coated } \\
\text { needle punched } \\
\text { fabrics }\end{array}$ \\
\hline \multirow{3}{*}{$\begin{array}{c}\text { Coating ratio } \\
\left(\mathrm{g} / \mathrm{m}^{2}\right)\end{array}$} & 30 & $39.03 \mathrm{a}$ & $61.08 \mathrm{a}$ & $49.17 \mathrm{a}$ & $30.00 \mathrm{a}$ \\
\cline { 2 - 6 } & 60 & $71.00 \mathrm{~b}$ & $66.33 \mathrm{a}$ & $69.83 \mathrm{~b}$ & $83.75 \mathrm{~b}$ \\
\hline \multirow{3}{*}{$\begin{array}{c}\text { Weft density } \\
(\mathrm{D})\end{array}$} & 90 & $64.41 \mathrm{~b}$ & $87.91 \mathrm{~b}$ & $86.58 \mathrm{c}$ & $85.83 \mathrm{~b}$ \\
\cline { 2 - 6 } & 7 & $55.75 \mathrm{a}$ & $59.75 \mathrm{a}$ & $32.08 \mathrm{a}$ & $38.91 \mathrm{a}$ \\
\cline { 2 - 6 } & 9 & $67.03 \mathrm{a}$ & $81.41 \mathrm{~b}$ & $52.08 \mathrm{~b}$ & $51.83 \mathrm{~b}$ \\
\hline
\end{tabular}

NOTE: The different letters next to the counts indicate that they are significantly different from each other at a significance level of $5 \%$.

processed with different coating ratios. The interaction of coating ratio and weft density on fabrics' seam slippage strength in both directions was also statistically significant.

SNK test results in table 7 revealed that all produced fabrics processed with different coating ratios $\left(\mathrm{g} / \mathrm{m}^{2}\right)$ possessed different seam slippage strength values in warp and weft direction at significance level of 0.05 . Our results may be supported with Jankoska and Demboski's study where the authors confirmed that some of the fabric structural parameters such as weft density, weft yarn count and some special treatments were statistically significant factors on the seam opening results [23]. Within the coated fabric groups, when considering the seam slippage in warp direction, the lowest value was obtained in the fabrics processed with $30 \mathrm{gr} / \mathrm{m}^{2}$ coating ratio while slippage strength values of fabric groups processed with 60 and 90 $\mathrm{g} / \mathrm{m}^{2}$ coating ratio were higher and in the same subset as at significance level of 0.05 . It is also useful to emphasize that there is a clear improvement of seam slippage strength in the weft direction as the coating ratio increased. This result may be attributed to coating material penetrating into the fabric structure intercepting the yarn mobility [24]. Positive influence of weft density on seam slippage strength was more apparent for the seam slippage strength values in weft direction when comparing with the seam slippage strength values in warp direction. Our result was supported with Özdemir and Yavuzkasap's study where seam slippage strength of upholstery fabrics in weft wise increased with the weft density increment [25]. When the coated needle punched fabrics are evaluated; Increment of coating ratio $\left(\mathrm{g} / \mathrm{m}^{2}\right)$ led to increment of seam strength in warp and weft wise. Seam slippage values in warp direction of the fabrics processed with 30 and $60 \mathrm{~g} / \mathrm{m}^{2}$ were in the same subset and lower than the seam slippage values of the fabrics processed with $90 \mathrm{~g} / \mathrm{m}^{2}$ coating ratio. Seam slippage values in weft direction of the fabric groups processed with 60 and $90 \mathrm{~g} / \mathrm{m}^{2}$ coating ratio were in the same subset and apparently higher than the seam cessed with $30 \mathrm{~g} / \mathrm{m}^{2}$ coating ratio. Increment of fabric weft density resulted with better seam slippage strength values especially in the weft direction.

\section{CONCLUSION}

Upholstery fabrics are the indispensable part of home textiles. The aim of this study was built on the investigation of effect of coating ratio $\left(\mathrm{g} / \mathrm{m}^{2}\right)$ and weft density on abrasion, pilling, air permeability and seam slippage strength properties of upholstery fabrics considering the needle punching process. According to two directions ANOVA tests, weft density, coating ratio $\left(\mathrm{g} / \mathrm{m}^{2}\right)$ and their interaction were insignificant factors for mass loss (\%) of needle punched-coated fabrics. However, coating ratio was a significant factor for the mass loss (\%) values among the fabrics treated to coating process without needle punching. Increment of coating ratio improved the abrasion results in terms of mass loss (\%) among this group. Pilling results did not vary prominently regarding to weft density or coating ratio however coated needle punched upholstery fabrics had higher pilling tendency. Coated needle punched upholstery fabrics indicated lower air permeability results when compared with their coated counterparts. Coating ratio $\left(\mathrm{g} / \mathrm{m}^{2}\right)$, weft density and their interaction significantly affected air permeability of all produced woven fabrics at significance level of 0.05 . Lower air permeability values were obtained from the all types of produced fabrics as the coating ratio $\left(\mathrm{g} / \mathrm{m}^{2}\right)$ and weft density increased.

According to test results, fabric structural parameters such as weft density and the coating ratio were thought to be influencing the seam slippage behaviour during deformation in the coated upholstery fabrics. Considering all fabric samples; Coating ratio, weft density and their interaction were significant factors on seam slippage strength forces in warp and weft wise except for in case. Weft density was not a significant factor for the seam slippage strength in warp wise among the coated fabric variants. Increment of weft density resulted with better seam slippage results in warp and weft direction among the whole fabric groups however the improvement was clearer for the seam slippage strength values in weft direction. Fabrics processed with higher coating ratio revealed better seam slippage strength values especially in the weft direction. It might be suggested to change some more coating process parameters such as coating speed, distance between knife and the rotary screen roller, paste viscosity and curing tem- 
perature for the evaluation of their influence on the woven upholstery fabrics' mechanical or comfort properties. This might be helpful for informing the suitable conditions for the most useful upholstery fabrics.

\section{ACKNOWLEDGMENT}

We wish to express our special thanks to Bülent ASLAN (production manager), Serkan ATAMAN, Bayram BAYSAL and all staff of TOSUNOĞLU Textile Company (Denizli, Turkey) for their technical support.

\section{BIBLIOGRAPHY}

[1] Singha, K. A., Review on coating \& lamination, in textiles: processes and applications, In: American Journal of Polymer Science, 2012, 2(3), pp. 39-49

[2] Schindler, W.D., Hauser, P. J., Chemical finishing of textiles, Elsevier, Textile Institute, Woodhead Publishing, 2004, ISBN 1855739054

[3] Fung, W, Coated and Laminated Textiles, Polymer Modified Textile Materials, New York, John Wiley and Sons, New York, 1988, pp. 50-58

[4] Smith, W.C. (Ed.), Smart textile coatings and laminates, ISBN: 9781845697785, Elsevier, 2010

[5] Wan, T., Stylios, G.K., Effects of coating process on the surface roughness of coated fabrics, In: The Journal of Textile Institute, 2017, 108(5), pp. 712-719

[6] Curran, J. A., Clyne, T.W., Thermo-physical properties of plasma electrolytic oxide coatings on aluminium, In: Surface and Coatings Technology, 2005, 199, pp. 168-176

[7] Parfenov, E.V., Yerokhin, A.L., Matthews, A., Frequency response studies for the plasma electrolytic oxidation process, In: Surface and Coatings Technology, 2007, 201, pp. 8661-8670

[8] Vedat, D., Ramazan, Ş., Lubos, H., Engin, A., Abdurrahim, Y., Investigation of thermal comfort properties of zinc oxide coated woven cotton fabric, In: The Journal of The Textile Institute, 2017, 108:3, pp. 337-340, DOI: $10.1080 / 00405000.2016 .1166819$

[9] Vildan, S., Cansu, M., Hülya, K., Yasemin, S., A comparative study on seam performance of cotton and polyester woven fabrics, In: Journal of the Textile Institute, 2015, 106:1, pp. 19-30

[10] Yasemin, B., Vildan, S., Effects of process parameters on mechanical properties of coated fabrics, In: International Journal of Clothing Science and Technology, 2011, 23, 4, pp. 205-221, https://doi.org/10.1108/09556221111136476

[11] Elbadawi, A. M., Pearson, J. S., Foam technology in textile finishing, In: Textile Progress, 2003, 33:4, pp. 1-31, DOI: $10.1080 / 00405160308688960$

[12] ISO 12947-3: Textiles. Determination of the abrasion resistance of fabrics by the Martindale method - Part 3 : Determination of mass loss, Switzerland, 1998

[13] Stojanović, P., Radmanovac, N., Trajković, D., Stepanović, J., Stepanović, J., The influence of texturing process parameters on yield points and breaking forces of pes filament yarns, In: Industria Textila, 2018, 69(4), pp. 281-286.

[14] 12945-2: 2000: Determination of resistance to pilling, Switzerland, 2000

[15] ISO 9237 Determination of air permeability of fabrics to air, Geneva, Switzerland, 1995

[16] Gurarda A. Investigation of the seam performance of PET/nylon-elastane woven fabrics, In: Textile Research Journal, 2008, 78 (1), pp. 21-27

[17] Malciauskiene, E., Milasius, A., Milasius, R., Influence of fabric structure parameters on seam slippage, In: Fibres \& Textiles in Eastern Europe, 2012, 20, 3(92), pp. 98-101

[18] ISO 13936-1: 2004. Determination of the slippage resistance of yarns at a seam in woven fabrics - Part 2: Fixed seam opening method, Switzerland, 2004

[19] Saville, B. P., Physical testing of textiles, Textile Institute, Woodhead Publishing, Elsevier, 1999

[20] Kavuşturan, Y., Çeven, E. K., Özdemir, Ö., Effect of chenille yarns produced with selected comfort fibres on the abrasion and bending properties of knitted fabrics, In: Fibres \& Textiles in Eastern Europe, 2010, 18(1), p. 78

[21] Namiranian, R., Shaikhzadeh, N. S., Etrati, S. M., Manich, A. M., Seam slippage and seam strength behaviour of elastic woven fabrics under static loading, In: Indian Journal of Fibre \& Textile Research (IJFTR), 2014, 39(3), pp. 221-229

[22] Yildirim, K., Predicting seam opening behavior of woven seat fabrics, In: Textile Research Journal, 2010, 80(5), pp. 472-480

[23] Jankoska, M., Demboski, G., Influence of weft density, weft yarn count and finishing on slippage resistance of yarns at seam, In: Advanced technologies, 2017, 6(2), pp. 78-83

[24] Izabela, J., Assessment of a fabric surface after the pilling process based on image analysis, In: Fibres \& Textiles in Eastern Europe, 2009, 17(2), p. 73

[25] Özdemir, H., Yavuzkasap, D., The effects of yarn and fabric structural parameters on the seam slippage, abrasion and pilling properties of double woven upholstery fabrics, In: Industria Textila, 2012, 63, 6, pp. 307-314

\section{Authors:}

\section{GIZEM KARAKAN GÜNAYDIN}

Pamukkale University, Buldan Vocational School, Fashion\&Design Programme, 20400, Buldan, Denizli, Turkey, e-mail: ggunaydin@pau.edu.tr

Corresponding author:

GIZEM KARAKAN GÜNAYDIN

e-mail: ggunaydin@pau.edu.tr 


\title{
Color matching model of woven fabric produced by multi-color blended rotor spun wool yarn
}

\author{
DOI: $10.35530 / I T .070 .04 .1586$
}

\section{REZUMAT - ABSTRACT}

Model de asortarea culorilor țesăturilor produse cu fire multicolore de lână filate cu rotor

Firele multicolore de lână au fost filate prin tehnologia de filare cu rotor cu 3 canale și a fost studiată caracteristica de culoare a țesăturii obţinută din aceste fire. Firele cu diferite rapoarte de amestecare a culorilor sunt filate din semitorturi pure de lână roșie, galbenă și albastră și apoi țesute. Modelarea amestecului de culori pentru ţesătura obţinută, corespunzător teoriei constante duble Kubelka-Munk, a fost realizată folosind două metode distincte: metoda celor mai mici pătrate și metoda valorii relative. Modelul a fost verificat prin calcularea diferenței de culoare dintre proba de țesătură și proporția de amestecare a fibrelor colorate. Rezultatele au arătat că diferențele medii de culoare ale probelor obţinute prin modelare sunt mai mici de 1,0, folosind oricare dintre metode. Eroarea medie a raportului de amestecare a fibrelor colorate, calculată utilizând modelul prin metodele de mai sus, este de 1,77\% și, respectiv, de 2,38\%. Se poate concluziona că, în comparație cu metoda valorii relative, metoda celor mai mici pătrate este mai bună pentru modelul $K-M$, în scopul predincţiei efectului de amestecare a culorilor și pentru raportul de amestecare al probelor.

Cuvinte-cheie: teoria K-M, efect de amestecare, predincţie, diferența de culoare, raport de amestecare

\section{Color matching model of woven fabric produced by multi-color blended rotor spun wool yarn}

Multi-color blended wool yarn was spun by three-channel rotor spinning technology, and the color feature of the corresponding woven fabric was studied. Blended yarns with different color mixing ratios are spun by pure rovings of red, yellow and blue wool, and then woven as fabric. The color blending model of Kubelka-Munk double constant theory for the woven fabrics was established using two methods: least squares method and relative value method. The model was verified by calculating color difference of the fabric sample and the blending proportion of colored fiber. The results showed that mean color differences of the samples predicted by the model is less than 1.0 using either method. The average blending ratio error of the colored fibers calculated using the model by the above methods is $1.77 \%$ and $2.38 \%$, respectively. It can be obtained that compared with relative value method, the least squares method is better for $K-M$ model to predict color blending effect and the blending ratio of the samples.

Keywords: K-M theory; blending effect; prediction; color difference; blending ratio

\section{INTRODUCTION}

Rotor spun is an open-end spinning process, by condensing single fibers as fiber strand in the rotor to form a yarn. Suitable materials for spinning can be cotton, wool, short chemical fiber and long chemical fiber, which are abundant [1-2]. The wool fibers used for this process are mostly short fibers such as fibers carded in the combing process. The aim is that the raw materials can be fully utilized and economic profit of the enterprise can be raised. Generally, multicolor wool fibers are mixed by slivers in the drawing process. Recently, multi-channel rotor spinning technology is proposed by modification on the traditional rotor spun machine [3]. Color blending can be carried out during the spinning process to realize simultaneously spinning and mixing colors. Besides, this process is flexible and efficient. The color features of the color-mixed fabric are affected by type, color, blending ratio of the fibers and weaving methods. Any change of these aspects can cause color character- istic variation [4-5]. Color matching is one of the key technical problems in textile industry. The researches of color matching methods for pre-colored fiber blends have been existed for years. Several methods have been introduced to describe the color blending of pre-colored fibers, such as Kubelka-Munk theory [6-7], Friele equation [8-9] and Stearns-Noechel model [10-11]. In this study, three-channel rotor spinning technology was used to obtain color blended wool yarn, and the color property of fabric woven with such yarns was also studied. The Kubelka-Munk double constant theory is used to study fabric color property and yarn blending ratio. The results can provide a theoretical reference for development of computer color matching system for color blended wool fabric.

\section{EXPERIMENTS}

The three-channel rotor spinning process is illustrated in figure 1. Major components include a combined 
feed roller, a carding device, a rotor and a yarn winding device. The combined roller includes three feed rollers that rotate around the same axis. Each feed roller is controlled by an independent servo motor with PLC system. The feed speeds of colored fibers are independent, thus fiber blending ratio of the spun yarn can be dynamically controlled [3]. During the spinning process, the three fiber strips are fed to the opening roller through their respective feeding rollers, and the continuous and tight fiber strips are separated into sparse fiber streams by splitting to achieve the separation and orientation of the fibers. Under the action of the acceleration airflow in the fiber transport channel, it is further separated into a single fiber form and enters the rotor. Under the action of high-speed rotation of the centrifugal force of the rotor, the single fibers are collected in the groove at the bottom of the rotor. Thus through the stripping, opening, cleaning, carding, and transfer of the carding roller, fiber bundles are separated into single fibers, and then multiple slivers asynchronously feeding into the rotor spun

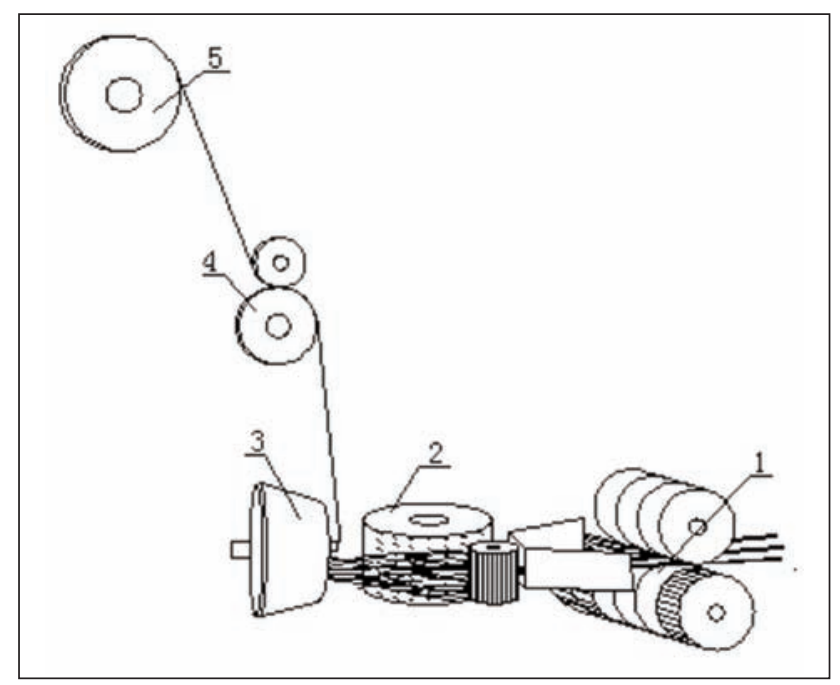

Fig. 1. Schematic diagram of the main components of multi-channel rotor spinning machine: 1 - combined feed rollers; 2 - carding roller; 3 - rotor; 4 - guide roller; 5 - yarn tube unit. Bundle is formed by multiple layers of combined condensation fibers and twisted to form a yarn by the blocking action of the false twisting disc, which is led by a mother yarn and wound into tube by winding roller.In this experiment, the rovings of red, yellow and blue wools are used as raw materials. 36 type of blended yarns are spun as listed in table 1. Yarn linear density is 44.85 Tex.

$3 / 1$ twill fabrics are woven with the color blended yarns. The warp density is $306 / 10 \mathrm{~cm}$ and the weft is $192 / 10 \mathrm{~cm}$. The woven fabric samples are shown in figure 2. 3-D mixed colors of colored fibers showed a gentler feature compared to powder mixed colors, as observed in figure 2 . These unique color scan satisfy consumers' pursuit of fashion and individuality, and provide unlimited imagination for the fashion designer. Color characteristics of fabrics were tested by Datacolor 650. It measured the spectral reflectance at a specific wavelength of the fabric, ranging from $360 \mathrm{~nm}$ to $700 \mathrm{~nm}$ at an interval of $10 \mathrm{~nm}$. During testing, the woven samples were folded 4 layers to ensure opaque and the $30 \mathrm{~mm}$ aperture was selected. In each sample, the colors at several locations were measured. The data with average color difference less than 0.2 CIELAB color unit were recorded. With the measured data, the K-M model was built.

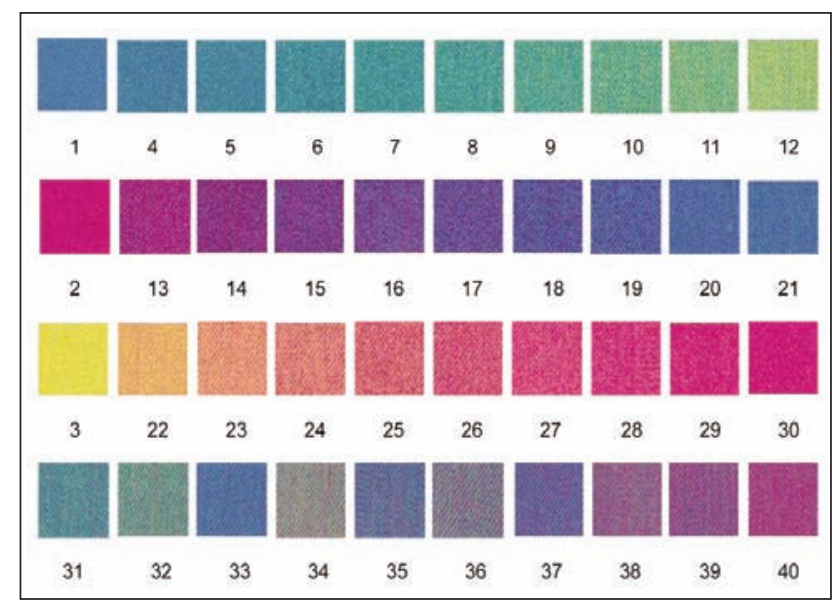

Fig. 2. Woven wool fabric with various fiber blending ratios

\begin{tabular}{|c|c|c|c|c|c|c|c|c|c|}
\hline \multicolumn{10}{|c|}{ COLOR BLEND SCHEME } \\
\hline No. & $\begin{array}{c}\text { Ratio of Red, } \\
\text { Yellow and } \\
\text { Blue }\end{array}$ & No. & $\begin{array}{c}\text { Ratio of Red, } \\
\text { Yellow and } \\
\text { Blue }\end{array}$ & No. & $\begin{array}{c}\text { Ratio of Red, } \\
\text { Yellow and } \\
\text { Blue }\end{array}$ & No. & $\begin{array}{c}\text { Ratio of Red, } \\
\text { Yellow and } \\
\text { Blue }\end{array}$ & $\begin{array}{c}\text { No. } \\
\text { Ratio of Red, } \\
\text { Yellow and } \\
\text { Blue }\end{array}$ \\
\hline 1 & $0: 0: 1$ & 9 & $0: 6: 4$ & 17 & $5: 0: 5$ & 25 & $4: 6: 0$ & 33 & $2: 1: 7$ \\
\hline 2 & $1: 0: 0$ & 10 & $0: 7: 3$ & 18 & $4: 0: 6$ & 26 & $5: 5: 0$ & 34 & $2: 4: 4$ \\
\hline 3 & $0: 1: 0$ & 11 & $0: 8: 2$ & 19 & $3: 0: 7$ & 27 & $6: 4: 0$ & 35 & $3: 2: 5$ \\
\hline 4 & $0: 1: 9$ & 12 & $0: 9: 1$ & 20 & $2: 0: 8$ & 28 & $7: 3: 0$ & 36 & $3: 4: 3$ \\
\hline 5 & $0: 2: 8$ & 13 & $9: 0: 1$ & 21 & $1: 0: 9$ & 29 & $8: 2: 0$ & 37 & $4: 1: 5$ \\
\hline 6 & $0: 3: 7$ & 14 & $8: 0: 2$ & 22 & $1: 9: 0$ & 30 & $9: 1: 0$ & 38 & $5: 3: 2$ \\
\hline 7 & $0: 4: 6$ & 15 & $7: 0: 3$ & 23 & $2: 8: 0$ & 31 & $1: 4: 5$ & 39 & $6: 2: 2$ \\
\hline 8 & $0: 5: 5$ & 16 & $6: 0: 4$ & 24 & $3: 7: 0$ & 32 & $1: 6: 3$ & 40 & $7: 2: 1$ \\
\hline
\end{tabular}




\section{K-M DOUBLE CONSTANT THEORY}

The Kubelka-Munk equation is derived from the complete radiation theory by revealing the relationship between color depth of the substrateand dyestuff concentration after the base fabric is coated with the paint [6-7]. The matched dye stuff is described by absorption coefficient and scattering coefficient, as shown in the following equation.

$$
\left(\frac{K}{S}\right)_{\lambda}=\frac{\left(1-R_{\lambda}\right)^{2}}{2 R_{\lambda}}
$$

In Equation $1, K$ is the absorption coefficient, $S$ - the scattering coefficient, $R_{\lambda}$ - the reflectivity of the sample at wave length $\lambda$.

When the Kubelka-Munk theory is used for blending effects of colored fibers, the $K / S$ value of the mixed fabric can be expressed as below.

$$
\frac{K}{S}=\frac{\sum_{i=1}^{n} C_{i} K_{i}}{\sum_{i=1}^{n} C_{i} S_{i}}
$$

In Equation 2, $i=1, \ldots, n$ is the monochromatic blending ratio, $C_{i}(i=1, \ldots, n)$ represents the proportion of the $i$-th colored fiber in the fabric, $K_{i}, S_{i}$ are the $K$ and $S$ values of each type of fibers in the fabric.

\section{Relative value method}

The relative value method is proposed by Burlone to solve the absorption coefficient and scattering coefficient of colored fibers in mixed color fabrics [12-13]. With this method, the relative value of $K$ and $S$ for a random color fiber can be obtained by using $K$ and $S$ of a specified colored fiber as a reference in the mixed color fabric. However, the true $K$ and $S$ values, representing real colors of the fibers, cannot be obtained with this method. For fabrics of two components, Equation 2 can be simplified as

$$
K / S=\frac{C_{1} K_{1}+C_{2} K_{2}}{C_{1} S_{1}+C_{2} S_{2}}
$$

Assuming $S_{1}=1, K_{1}=(K / S)_{1}$, Then

$$
\begin{aligned}
& S_{2}=\frac{C_{1}\left[(K / S) S_{1}-K_{1}\right]}{C_{2}\left[(K / S)_{2}-K / S\right]} \\
& K_{2}=(K / S)_{2} S_{2}
\end{aligned}
$$

Where: $C_{1}, C_{2}$ are the ratios of each monochromatic sample, respectively; $K_{1}, K_{2}, S_{1}, S_{2}$ are $K$ and $S$ values of the monochromatic, respectively; $(K / S)_{1}$ and $(K / S)_{2}$ are the $K / S$ value of each monochrome fabric, respectively.

\section{Least square method}

The least squares method is a set of linear independent equations proposed by Walowit.

A matrix operation is used to determine parameters of the equations so that the difference between the predicted and the true value of the dependent variable is minimal [14-16].The equations can be expressed as Equation 6:

$$
\begin{aligned}
& Y_{1}=X_{1} B_{1,1}+X_{2} B_{1,2}+X_{3} B_{1,3}+\ldots+X_{n} B_{1, n} \\
& Y_{2}=X_{1} B_{2,1}+X_{2} B_{2,2}+X_{3} B_{2,3}+\ldots+X_{n} B_{2, n} \\
& \vdots \quad \vdots \quad \vdots \quad \vdots \quad \vdots \quad \\
& Y_{m}=X_{1} B_{m, 1}+X_{2} B_{m, 2}+X_{3} B_{m, 3}+\ldots+X_{n} B_{m, n}
\end{aligned}
$$

Then Equation 6 can be converted to Equation 7 .

$\boldsymbol{Y}=\boldsymbol{B} \boldsymbol{X}$
Wherein $\boldsymbol{Y}=\left[\begin{array}{c}Y_{1} \\ Y_{2} \\ \vdots \\ Y_{m}\end{array}\right], \boldsymbol{X}=\left[\begin{array}{c}X_{1} \\ X_{2} \\ \vdots \\ X_{n}\end{array}\right], \boldsymbol{B}=\left[\begin{array}{ccc}B_{1,1} & \cdots & B_{1, n} \\ B_{2,1} & \cdots & B_{2, n} \\ \vdots & & \vdots \\ B_{m, 1} & \cdots & B_{m, n}\end{array}\right]$

According to the least squares matrix operation, the solution of the required parameter $\mathrm{X}$ can be obtained with Equation 8.

$$
\boldsymbol{X}=\left(\boldsymbol{B}^{\top} \boldsymbol{B}\right)^{-1} \boldsymbol{B}^{\top} \boldsymbol{Y}
$$

When this method is applied to K-M theory, the $K$ and $S$ values of each colored fiber in the fabric can be solved, and the color mixing ratio of each monochromatic fiber in the mixed color fabric can be obtained.

\section{Calculation of color difference}

The difference between the predicted color by the model and that of the actual sample is an important indicator for evaluating accuracy of the model. In this research, the color difference was calculated by $C M C(I: C)$ as demonstrated by Equation (9).

$$
\Delta E_{C M C}=\left[\left(\frac{\Delta L}{I S_{L}}\right)^{2}+\left(\frac{\Delta C}{c S_{C}}\right)^{2}+\left(\frac{\Delta H}{S_{H}}\right)^{2}\right]^{1 / 2}
$$

Where $I=2, c=1$.

\section{RESULTS AND DISCUSSION}

The above two methods are used to solve $K$ and $S$ of the coloredfibers in woven fabric. Kubelka-Munk double constant theory for fabrics woven by three-channel rotor spun color blending yarn also checked with the methods. In this experiment, samples No. 1-21 were used to solve the $K$ and $S$ values using the relative value method as shown in figure 3 . During the calculation, the scattering coefficient of the blue fiber was set as $1 . K$ and $S$ values of red and yellow fibers are solved by blending with blue fibers at different proportions separately. Average value of each ratio is taken as the final result. Samples 4-30 were used for the model with the least squares method to solve $K$ and $S$ as demonstrated in figure 4 . Samples No. 3140 were used to verify the color matching model.

According to the $K$ and $S$ valuescalculated by the above two methods at different wavelengths, the K/S values of fabrics woven by different colored fibers can be calculated according to Equation 2. Then reflectance of the mixed color fabric can be predicted by Equation 10.

$$
R=1+K / S-\left[(K / S)^{2}+2 \times K / S\right]^{1 / 2}
$$

According to the measured reflectivity $R$ of the verified sample and the $K$ and $S$ values of each colored 


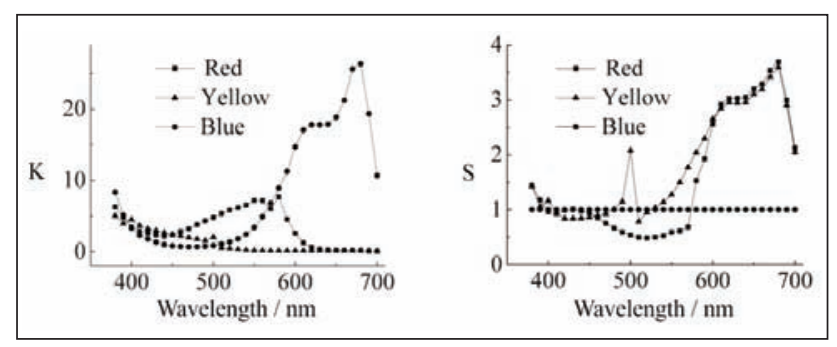

Fig. 3. $K$ and $S$ values solved by the relative value method

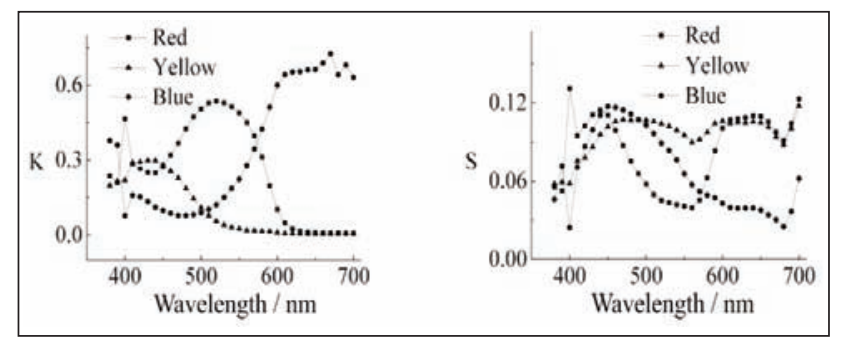

Fig. 4. $K$ and $S$ values solved by the least squares method

Table 2

\begin{tabular}{|c|c|c|c|c|c|c|c|c|}
\hline \multicolumn{9}{|c|}{ PREDICTED RESULTS OF THE MODELS } \\
\hline \multirow[b]{2}{*}{ No. } & \multicolumn{4}{|c|}{ The least squares method } & \multicolumn{4}{|c|}{ The relative value method } \\
\hline & $\begin{array}{c}\text { Color } \\
\text { difference }\end{array}$ & $\begin{array}{l}\text { Actual } \\
\text { ratios }\end{array}$ & Predicted ratios & $\begin{array}{l}\text { Ratio } \\
\text { error }\end{array}$ & $\begin{array}{c}\text { Color } \\
\text { difference }\end{array}$ & $\begin{array}{l}\text { Actual } \\
\text { ratios }\end{array}$ & Predicted ratios & $\begin{array}{l}\text { Ratio } \\
\text { error }\end{array}$ \\
\hline 31 & 0.69 & $0.1: 0.4: 0.5$ & 0.110:0.392:0.498 & $2.02 \%$ & 0.51 & $0.1: 0.4: 0.5$ & 0.109:0.392:0.499 & $1.81 \%$ \\
\hline 32 & 0.52 & 0.1:0.6:0.3 & 0.105:0.590:0.305 & $2.04 \%$ & 0.88 & 0.1:0.6:0.3 & 0.109:0.583:0.309 & $3.49 \%$ \\
\hline 33 & 0.36 & $0.2: 0.1: 0.7$ & 0.199:0.106:0.695 & $1.19 \%$ & 0.47 & 0.2:0.1:0.7 & 0.202:0.108:0.690 & $1.96 \%$ \\
\hline 34 & 0.74 & $0.2: 0.4: 0.4$ & 0.202:0.393:0.405 & $1.49 \%$ & 0.71 & 0.2:0.4:0.4 & 0.203:0.389:0.407 & $2.17 \%$ \\
\hline 35 & 0.58 & 0.3:0.2:0.5 & 0.312:0.189:0.499 & $2.38 \%$ & 0.63 & 0.3:0.2:0.5 & 0.311:0.188:0.500 & $2.32 \%$ \\
\hline 36 & 0.35 & 0.3:0.4:0.3 & 0.309:0.386:0.305 & $2.86 \%$ & 0.36 & 0.3:0.4:0.3 & 0.308:0.381:0.311 & $3.86 \%$ \\
\hline 37 & 0.58 & $0.4: 0.1: 0.5$ & 0.404:0.110:0.487 & $2.69 \%$ & 0.64 & $0.4: 0.1: 0.5$ & 0.406:0.107:0.487 & $2.65 \%$ \\
\hline 38 & 0.19 & 0.5:0.3:0.2 & 0.496:0.303:0.202 & $0.82 \%$ & 0.54 & 0.5:0.3:0.2 & 0.498:0.296:0.206 & $1.25 \%$ \\
\hline 39 & 0.16 & $0.6: 0.2: 0.2$ & 0.597:0.201:0.202 & $0.52 \%$ & 0.47 & $0.6: 0.2: 0.2$ & 0.599:0.195:0.206 & $1.25 \%$ \\
\hline 40 & 0.38 & $0.7: 0.2: 0.1$ & 0.704:0.192:0.105 & $1.70 \%$ & 0.83 & $0.7: 0.2: 0.1$ & 0.704:0.186:0.111 & $2.80 \%$ \\
\hline
\end{tabular}

fiber, the color difference between the predicted and the actual is calculated. Additionally, the blending ratio of each colored fiber in the samples is predicted by the least squares method, and the resultsare shown in the table 2.

As demonstrated by table 2, the color difference of the samplesis less than 1.0, and the average color difference is 0.46 when predicted with the least square method. The average ratio error of all verified samples is $1.77 \%$, which means the color matching results are good. The color differences of the samples predicted by the relative value method isaround 1.0 , and the average value is 0.60 . The mean value error between the predicted ratio and the actual ratio of all the verified samples is $2.36 \%$. It can be concluded that mean color difference of the samples are all less than 1.0 predicted by the models using either method. The average color differences predicted by the least squares method was 0.14 smaller than that using the relative value method, and the average ratio error was $0.59 \%$ smaller. Thus, it can be inferred that the model built by the least square method is better to predict the color and blending ratio of fabrics woven by multi-channel rotor spun color blended wool yarn.

\section{CONCLUSION}

The three-channel rotor spinning technology is used to develop color blended wool yarns. Its unique color mixing method and on-line control of color blending ratio have great advantages in production of blended yarns. The absorption coefficient $K$ and scattering coefficient $S$ of red, yellow and blue fibers are solved by relative value method and least squares method, respectively. Kubelka-Munk double constant theory for the yarn was established by the above methods. With this model, the color and fiber blending ratio can be predicted. Corrrespondingly, the color difference and blending ratio erro can becalculated. The results show that the average color difference predictedusing the model by the two methods are than 1, which satisfies color matching requirements. Compared with relative value method, the least squares method is better for K-M model to predict color blending effect and the blending ratio of the samples. Moreover, this research provided a theoretical reference for further computer intelligent color matching of fabrics woven by three-channel rotor spun color blended yarn.

\section{ACKNOWLEDGEMENT}

This work was supported by Natural Science Foundation of Jiangsu Province of China No. BK20181350, the National Natural Science Foundation of China No. 51403085, National Key R\&D Program of China (2017YFB0309200), the Fundamental Research Funds for the Central Universities No. JUSRP51631A, and Priority Academic Program Development of Jiangsu Higher Education Institutions (PAPD). 


\section{BIBLIOGRAPHY}

[1] Ahmad, Z., Eldeeb, M., Iqbal, S., et al., Effect of yarn structure on cover factor in woven fabrics, In: Industria Textila, 2018, 69, 3, pp. 197-201

[2] Yang, R. H., Xue, Y., Gao, W. D., Airflow characteristics of different groove type during rotor spinning process, In: Industria Textila, 2017, 68, 3, pp. 65-169

[3] Yang, R.H., Xue, Y., Gao, W.D., Structure and performance of color blended rotor spun yarn produced by a novel frame with asynchronous feed rollers, In: Textile Research Journal, DOI: 10.1177/ 0040517517748493

[4] Shen, J.J., Ma, H., Chen, W.G., A novel analysis of color component for top dyed melange yarn with support vector machine, In: Color Reseacher and Application, 2016, 41, 6, pp. 636-641

[5] Chae, Y., Xin, J.H., Hua, T., Color prediction models for digital Jacquard woven fabrics, In: Color Research and Application, 2016, 41, 1, pp. 64-71

[6] Davidson, H.R., Hemmendinger, H., Color prediction using the Two-Constant Turbid-Media theory, In: Journal of the Optical Society of America, 1966, 56, 8, pp. 1102-1109

[7] Allen, E., Basic equations used in computer color matching, II. Tristimulus match, two-constant theory, In: Journal of the Optical Society of America, 1974, 64, 7, pp. 991-993

[8] Philips, B., Dupont, D., Caze, C., Formulation of coloredfiber blends from Friele's theoretical model, In: Color Research and Application, 2002, 27, 3, pp. 191-198

[9] Friele, L.F.C., The application of color measurement in relation to fibre-blending, In: Journal of the Textile Institute Proceedings, 1952, 43, 8, pp. 604-611

[10] Stearns, E.I., Noechel, F., Spectrophotometric prediction of color of wool blends, In: American Dyestuff Reporter, 1944, 33, 9, pp. 177-180

[11] Yang, R.H., Han, R.Y., Lu, Y.Z., Xue, Y., Gao, W.D., Color matching of fiber blends: Stears-Noechel model of digital rotor spun yarn, In: Color Research and Application, 2018, 43, 3, pp. 415-422

[12] Burlone, D.A., Formulation of blends of precolored nylon fiber, In: Color Research and Application, 1983, 8, 2, pp. $114-120$

[13] Burlone, D.A., Effect of fibertransluceny on the color of blend of precoloredfibers, In: Textile Research Journal, 1990, 15, 3, pp. 162-167

[14] Walowit, E., An algorithm for the optimization of Kubelka-Munk absorption and scattering coefficients, In: Color Research and Application, 1987, 12, 6, pp. 340-343

[15] Amirshahi, S.H., Pailthorpe, M.T., Applying the Kubelka-Munk equation to explain the color of blends prepared from precoloredfibers. In: Textile Research Journal, 1994, 64, 6, pp. 357-364

[16] Seyam, A.F.M., Mathur, K., A general geometrical model for predicting color mixing of woven fabrics from colored warp and filling yarns, In: Fibers and Polymers, 2012, 13, 6, pp. 795-801

\section{Authors:}

RUI HUA YANG, YAYA XU, CHUN PING XIE, BO JUN XU, HONG BO WANG, WEI DONG GAO

Key Laboratory of Science \& Technology for Eco-Textiles, Education Ministry, Jiangnan University, 1800 Lihu Avenue, Wuxi, Jiangsu Province, 214122, P.R. China

e-mail of each author: yangrh@jiangnan.edu.cn, 309167947@qq.com,wxxchp@vip.163.com,wxxbj@sina.com, wxwanghb@163.com, gaowd3@163.com

\section{Corresponding author:}

RUI HUA YANG

e-mail: yangrh@jiangnan.edu.cn 